\title{
Coral Biomineralization, Climate Proxies and the Sensitivity of Coral Reefs to $\mathrm{CO}_{2}$-Driven Climate Change
}

\author{
by \\ Thomas Mario DeCarlo \\ B.A., University of San Diego (2012)
}

Submitted in partial fulfillment of the requirements for the degree of

Doctor of Philosophy

at the

MASSACHUSETTS INSTITUTE OF TECHNOLOGY

and the

WOODS HOLE OCEANOGRAPHIC INSTITUTION

February 2017

(C)2017 Thomas M. DeCarlo. All rights reserved. The author hereby grants to MIT and WHOI permission to reproduce and to distribute publicly paper and electronic copies of this thesis document in whole or in part in any medium now known or hereafter created.

Author

Joint Program in Oceanography/Applied Ocean Science \& Engineering Massachusetts Institute of Technology \& Woods Hole Oceanographic Institution October 12, 2016

Certified by

Dr. Anne L. Cohen Associate Scientist, Department of Geology and Geophysics, WHOI Thesis Supervisor

Accepted by

Dr. Timothy L. Grove Professor of Earth, Atmospheric, and Planetary Sciences, MIT Chairman, Joint Committee for Marine Geology and Geophysics 


\title{
Coral Biomineralization, Climate Proxies and the Sensitivity of Coral Reefs to $\mathrm{CO}_{2}$-Driven Climate Change
}

by

\author{
Thomas Mario DeCarlo
}

\begin{abstract}
Scleractinian corals extract calcium $\left(\mathrm{Ca}^{2+}\right)$ and carbonate $\left(\mathrm{CO}_{3}^{2-}\right)$ ions from seawater to construct their calcium carbonate $\left(\mathrm{CaCO}_{3}\right)$ skeletons. Key to the coral biomineralization process is the active elevation of the $\mathrm{CO}_{3}^{2-}$ concentration of the calcifying fluid to achieve rapid nucleation and growth of $\mathrm{CaCO}_{3}$ crystals. Coral skeletons contain valuable records of past climate variability and contribute to the formation of coral reefs. However, limitations in our understanding of coral biomineralization hinder the accuracy of (1) coral-based reconstructions of past climate, and (2) predictions of coral reef futures as anthropogenic $\mathrm{CO}_{2}$ emissions drive declines in seawater $\mathrm{CO}_{3}^{2-}$ concentration.

In this thesis, I investigate the mechanism of coral biomineralization and evaluate the sensitivity of coral reef $\mathrm{CaCO}_{3}$ production to seawater carbonate chemistry. First, I conducted abiogenic $\mathrm{CaCO}_{3}$ precipitation experiments that identified the $\mathrm{U} / \mathrm{Ca}$ ratio as a proxy for fluid $\mathrm{CO}_{3}^{2-}$ concentration. Based on these experimental results, I developed a quantitative coral biomineralization model that predicts temperature can be reconstructed from coral skeletons by combining $\mathrm{Sr} / \mathrm{Ca}$ - which is sensitive to both temperature and $\mathrm{CO}_{3}^{2-}$ - with $\mathrm{U} / \mathrm{Ca}$ into a new proxy called "Sr-U". I tested this prediction with 14 corals from the Pacific Ocean and the Red Sea spanning mean annual temperatures of $25.7-30.1{ }^{\circ} \mathrm{C}$ and found that $\mathrm{Sr}-\mathrm{U}$ has uncertainty of only 0.5 ${ }^{\circ} \mathrm{C}$, twice as accurate as conventional coral-based thermometers. Second, I investigated the processes that differentiate reef-water and open-ocean carbonate chemistry, and the sensitivity of ecosystem-scale calcification to these changes. On Dongsha Atoll in the northern South China Sea, metabolic activity of resident organisms elevates reef-water $\mathrm{CO}_{3}^{2-}$ twice as high as the surrounding open ocean, driving rates of ecosystem calcification higher than any other coral reef studied to date. When high temperatures stressed the resident coral community, metabolic activity slowed, with dramatic effects on reef-water chemistry and ecosystem calcification. Overall, my thesis highlights how the modulation of $\mathrm{CO}_{3}^{2-}$, by benthic communities on the reef and individual coral polyps in the colony, controls the sensitivity of coral reefs to future ocean acidification and influences the climate records contained in the skeleton.
\end{abstract}

Thesis Supervisor: Dr. Anne L. Cohen

Title: Associate Scientist, Department of Geology and Geophysics, WHOI 


\section{Acknowledgments}

I am grateful for the support and guidance of my advisor, Dr. Anne Cohen. When I first came to WHOI as a summer student in 2011, Anne got me so hooked on corals that I just had to come back for a Ph.D. I started in the Joint Program with the expectation that my research would consist primarily of geochemical analyses in the laboratory, but Anne had a lot more in store for me. From building a 5-story scaffolding tower on the seafloor, to eating a Taiwanese MRE as the windows of the marine-lab basement shook during a live-fire military drill, to diving on a reef in the middle of the Pacific thousands of miles from anything, it has been quite a journey, and I am thankful for the experiences and opportunities.

Thanks to my committee for always being there when I needed help. Your collective knowledge was invaluable over the past few years. I owe special thanks to Glenn Gaetani for guidance in abiogenic precipitation experiments, George Wong for bringing me to Taiwan for the field research that became so critical to my thesis, and of course to Kristen Davis for the can-do attitude that got me through the struggles, and the successes, of working in the field on Dongsha.

I am thankful for the great friends I made and the tremendous help they gave me along the way. I met Pat Lohmann in Bermuda, and on our first dive together when I saw him, nearly out of air, rubbing his arm against fire coral with a big smile on his face, I figured it would be hard to work with this crazy guy. Little did I know that we would go in the field together about a dozen times and he would even be the witness at my wedding. I owe huge thanks to Michael Holcomb for his guidance in conducting abiogenic precipitation experiments, and for taking the night-shift during the two months we worked in the lab together. To all the students in the Cohen lab, it was a pleasure to work with everyone in the lab and in the field, and I owe a lot to thoughtful discussions with you all. Lisa Hou, Kuo-Yuan Lee, and Yalan Chou were instrumental in making Dongsha fieldwork not only possible, but successful.

A very special thank you to my loving wife, Laura. You always light up my day and put a twinkle in my eye. You give me the motivation to always put my best effort forward. I truly feel the most fortunate person in the world to have met you on Dongsha Atoll, and I cannot wait to for all the great adventures to come.

This research was funded by a National Science Foundation (NSF) Graduate Research Fellowship, NSF grants OCE 1041106, OCE 1338320, and OCE 1220529, by a thematic project at Academia Sinica, Taiwan, the WHOI Ocean Ventures Fund, and by the WHOI Coastal Ocean Institute. 


\section{Contents}

1 Introduction $\quad 9$

2 Experimental determination of factors controlling $\mathrm{U} / \mathrm{Ca}$ of aragonite precipitated from seawater

3 Coral Sr-U Thermometry

4 Coral bioerosion is accelerated by ocean acidification and nutrients 85

5 Community production modulates coral reef $\mathrm{pH}$ and the sensitivity of ecosystem calcification to ocean acidification

6 Mass coral mortality under local amplification of $2{ }^{\circ} \mathrm{C}$ ocean warming

7 Conclusions and Future Directions

A Chapter 2 Steady-State Model

B Data for Chapter 2

C Data for Chapter 3

D Data for Chapter 4

E Data for Chapter 5

F Data for Chapter 6 


\section{Chapter 1}

\section{Introduction}

The surface ocean has warmed by $1{ }^{\circ} \mathrm{C}$ and its carbonate ion concentration $\left(\left[\mathrm{CO}_{3}^{2-}\right]\right)$ has decreased by $40 \mu \mathrm{mol} \mathrm{kg}{ }^{-1}$ (15\%) over the past century (Feely et al., 2009; Stocker et al., 2013). Global climate and earth-system models project these trends to continue, and they paint a picture of a year-2100 ocean that is $1-4{ }^{\circ} \mathrm{C}$ warmer and has $\left[\mathrm{CO}_{3}^{2-}\right] 30 \%$ lower than today (Feely et al., 2009; Meehl et al., 2012; Stocker et al., 2013). These changes are predicted to have devastating consequences for reefbuilding corals (Hoegh-Guldberg et al., 2007). Ocean acidification (decreased $\left[\mathrm{CO}_{3}^{2-}\right]$ ) increases bioerosion of coral skeleton (Wisshak et al., 2012), and decreases both coral colony calcification (Chan and Connolly, 2013) and net coral reef calcification (Albright et al., 2016). In combination, warming of the sea surface will likely cross thresholds of coral thermal tolerance on most of the world's reefs within this century (van Hooidonk et al., 2013), and even though some corals show evidence of adaptation (Palumbi et al., 2014), they are unlikely to do so in time (Frieler et al., 2012).

The overarching theme of my thesis is to understand the rapid changes occurring in our oceans, and the sensitivity of coral reef ecosystems to these changes. Addressing this question is inherently multi-disciplinary and requires investigations across multiple temporal and spatial scales. We need to understand how corals control $\left[\mathrm{CO}_{3}^{2-}\right]$ at the site of biomineralization, potentially modulating their sensitivity to changes in seawater $\left[\mathrm{CO}_{3}^{2-}\right]$. We need to reconstruct reef temperatures into the past, but to

do this with corals we must understand how they influence the composition of their 
skeleton during the biomineralization process. And we need to identify processes driving differences between reef-water and open-ocean chemistry, which will modulate the sensitivity of these ecosystems to climate changes.

Here, I investigate carbonate chemistry at the site of coral biomineralization, I examine how corals record ocean temperatures within their skeletons, and I evaluate the drivers of reef-water carbonate chemistry and temperature. First, I conducted laboratory experiments to test the $\left[\mathrm{CO}_{3}^{2-}\right]$ control on abiogenic aragonite $\mathrm{U} / \mathrm{Ca}$ ratios, and I modeled the coral biomineralization process in order to predict $\left[\mathrm{CO}_{3}^{2-}\right]$ of the coral's calcifying fluid. With this model, I developed a new geochemical-based coral paleothermometer, "Sr-U", and I tested its accuracy using coral colonies sampled across the Pacific Ocean and the Red Sea. Further, I tested the sensitivity of coral bioerosion rates to natural gradients of seawater $\left[\mathrm{CO}_{3}^{2-}\right]$ spanning the tropical Pacific Ocean. Finally, on Dongsha Atoll in the northern South China Sea, I evaluated the drivers of reef-water temperature and $\left[\mathrm{CO}_{3}^{2-}\right]$, and the response of the coral community to changes in the reef's chemical and thermal environments.

\subsection{Coral biomineralization}

The process of coral biomineralization - biologically mediated mineral precipitation underpins the growth of coral colonies and reefs, and preserves snapshots of past climates within coral skeletons. Corals actively construct their skeletons by nucleating and growing crystals of the $\mathrm{CaCO}_{3}$ mineral aragonite. Aragonite is supersaturated ${ }^{1}$ in surface waters of the tropical oceans, meaning that it can precipitate naturally from seawater. Corals, however, build their aragonitic skeletons orders of magnitude faster than rates of abiogenic aragonite precipitation, suggesting that they exert strong control on this process. Understanding the biomineralization process is key to understanding how corals record past climates, and how they will respond to changes in ocean chemistry. Yet, despite decades of research, the mechanisms by which corals

\footnotetext{
${ }^{1}$ Aragonite saturation state $\left(\Omega_{\text {Arag }}\right)=\left[\mathrm{CO}_{3}^{2-}\right]\left[\mathrm{Ca}^{+}\right] / \mathrm{Ksp}^{\prime}>1$, where Ksp' is the apparent solubility product
} 
achieve such rapid calcification have not been completely resolved.

Multiple lines of evidence point to the existence of a micro-scale, isolated, extracellular calcifying space supplied with seawater. Barnes (1970) first suggested that skeletal aragonite crystals grow in an isolated fluid, and this was later observed directly by Venn et al. (2011). Evidence supporting seawater as the source of the calcifying fluid comes from microscopy experiments and geochemistry. Tambutté et al. (2012) reared corals in seawater spiked with fluorescent calcein dye and observed extracellular seawater transport pathways between the external seawater and the site of biomineralization. Further, corals grown in seawater spiked with rare earth elements rapidly incorporate those elements into the growing skeletal surface (Gagnon et al., 2012), and the isotopic (e.g. $\delta^{13} \mathrm{C}$ and $\delta^{18} \mathrm{O}$ ) and elemental (e.g. $\mathrm{Mg} / \mathrm{Ca}$ and $\mathrm{Sr} / \mathrm{Ca}$ ) ratios in coral skeleton are consistent with partitioning between aragonite and a seawater source (McConnaughey, 1989a,b; Cohen and McConnaughey, 2003; Cohen et al., 2006; Gaetani and Cohen, 2006; Holcomb et al., 2009; Gaetani et al., 2011). While these lines of evidence strongly suggest that corals precipitate their skeletons from a fluid of similar elemental and isotopic composition to seawater, they do not explain how corals calcify at rates greatly exceeding those of aragonite precipitation from ambient seawater.

Additional evidence indicates that corals achieve rapid crystal nucleation and growth by altering the carbonate chemistry of their calcifying fluid. Micro-electrodes inserted into the calcifying fluid reveal pH of 9.3 or higher (Al-Horani et al., 2003; Ries, 2011; Cai et al., 2016), which is substantially elevated above that of ambient seawater (typically 8.0 - 8.1). These data are generally consistent with independent approaches based on growing corals in pH-sensitive dyes (Venn et al., 2011), and the boron isotopic ratio of coral skeletons - a proxy for $\mathrm{pH}$ of the fluid from which the crystals precipitated (Trotter et al., 2011; Rollion-Bard et al., 2011; McCulloch et al., 2012). Nevertheless, pH information alone is insufficient to completely constrain the chemical changes occurring within the calcifying fluid. To fully characterize the carbonate system, another parameter is required.

A promising proxy for filling this gap lies in skeletal $\mathrm{U} / \mathrm{Ca}$ ratios because uranium 
speciation in seawater is controlled by carbonate ion concentration $\left(\left[\mathrm{CO}_{3}^{2-}\right]\right)$ (Djogic et al., 1986). If coral $\mathrm{U} / \mathrm{Ca}$ ratios are proven as a reliable $\left[\mathrm{CO}_{3}^{2-}\right]$ proxy, they would provide the second parameter needed to fully characterize the calcifying fluid carbonate system. However, the abiogenic temperature and carbonate chemistry controls on aragonite $\mathrm{U} / \mathrm{Ca}$ ratios have yet to be tested, so far precluding the application of $\mathrm{U} / \mathrm{Ca}$ in understanding coral biomineralization.

\subsection{Coral paleothermometry}

Coral skeletons are potentially valuable high-resolution archives of tropical climate. Their annually banded skeletons provide intrinsic time-markers, and some colonies grow continuously for several centuries. Well-preserved fossil skeletons have been dated to the beginning of the past millennium (Cobb et al., 2003), and even into the early Holocene (DeLong et al., 2010). As corals grow, they incorporate various elements from seawater into their skeletal aragonite crystals, and the relative concentrations of certain elements are sensitive to temperature. In particular, the $\mathrm{Sr} / \mathrm{Ca}$ ratio of aragonite depends on temperature in laboratory precipitation experiments (Kinsman and Holland, 1969; Gaetani and Cohen, 2006), and Sr/Ca ratios in coral skeletons often show seasonal variability coherent with sea surface temperatures (Smith et al., 1979). Based on these correlations, coral Sr/Ca is commonly applied to reconstruct ocean temperatures decades, centuries, and even millennia into the past (Smith et al., 1979; Felis et al., 2009; Hereid et al., 2013; Tierney et al., 2015; Toth et al., 2015). However, these reconstructions are rooted in the assumption that corals calcify directly from ambient seawater and that the coral itself plays a negligible role in mediating the composition of its skeleton.

The strong control exerted by corals in controlling the composition of their calcifying fluid has significant implications for the application of coral skeletons as climate proxies. As corals elevate their calcifying fluid $\left[\mathrm{CO}_{3}^{2-}\right]$ to nucleate aragonite crystals, the chemical composition of the fluid changes. Certain element ratios, such as $\mathrm{Sr} / \mathrm{Ca}$, are enriched in aragonite relative to seawater, and these ratios therefore become de- 
pleted in the residual calcifying fluid. This process, known as Rayleigh fractionation, is responsible for more than half of the variance in coral $\mathrm{Sr} / \mathrm{Ca}$ ratios (Cohen et al., 2006; Gaetani and Cohen, 2006; Gaetani et al., 2011). For this reason, Sr/Ca-based temperature reconstructions are frequently plagued by biases and decouplings from observed temperatures (Marshall and McCulloch, 2002; Felis et al., 2009; Grove et al., 2013; Storz et al., 2013; Wu et al., 2014; Karnauskas et al., 2015; Alpert et al., 2016). Coral-based paleothermometers must account for the effects of Rayleigh fractionation if they are to provide accurate temperature information. In attempts to resolve only the desired temperature signal from $\mathrm{Sr} / \mathrm{Ca}$ ratios, multiple studies have applied various corrections to $\mathrm{Sr} / \mathrm{Ca}$ based on coral growth rates, replicating time series, and sampling along certain regions of the skeleton (de Villiers et al., 1994; Saenger et al., 2008; DeLong et al., 2013). Despite these efforts, coral Sr/Ca continues to be afflicted with variance unrelated to temperature (Felis et al., 2009; Wu et al., 2014). A new approach is needed, one based on understanding the coral biomineralization process.

\subsection{Coral reef $\mathrm{CaCO}_{3}$ budgets}

Coral reefs are built primarily of $\mathrm{CaCO}_{3}$ formed biogenically by a wide array of calcifying organisms, combined with abiogenic cementation. As a counterbalance to these constructive processes, $\mathrm{CaCO}_{3}$ is removed from reefs via physical transport, dissolution in carbonate sands, and bioerosion - the biologically mediated breakdown and dissolution of coral skeleton by a broad range of taxa (Glynn, 1997). Production of $\mathrm{CaCO}_{3}$ must equal or exceed removal of $\mathrm{CaCO}_{3}$ in order for coral reefs to maintain their position near the sea surface, especially during times of rising sea levels. Most coral reefs today are thought to have net positive $\mathrm{CaCO}_{3}$ budgets, but with gross production only slightly exceeding gross removal (Stearn et al., 1977; Glynn, 1997). This close balance leaves coral reefs potentially vulnerable to any processes that alter calcification or dissolution.

Ocean acidification jeopardizes coral reef $\mathrm{CaCO}_{3}$ budgets by tipping the balance between calcification and dissolution. Despite the ability of corals to modify the 
composition of their calcifying fluid, they are sensitive to variations in the carbonate chemistry of the seawater in which they grow. Multiple laboratory experiments in which corals were reared in seawater with manipulated $\mathrm{CO}_{2}$ chemistry show declines in calcification rates with decreases in $\left[\mathrm{CO}_{3}^{2-}\right]$ (Langdon and Atkinson, 2005; Chan and Connolly, 2013). Additional experiments show that bioerosion of coral skeleton increases as $\left[\mathrm{CO}_{3}^{2-}\right]$ decreases (Wisshak et al., 2012). These results have ignited concern that corals worldwide are at risk of decreased calcification and increased bioerosion rates as ocean acidification drives down open-ocean $\left[\mathrm{CO}_{3}^{2-}\right]$ (Hoegh-Guldberg et al., 2007; Pandolfi et al., 2011). Together, the sensitivities of calcification and bioerosion to seawater $\left[\mathrm{CO}_{3}^{2-}\right]$ indicate that the $\mathrm{CaCO}_{3}$ balance of coral colonies, and potentially of coral reef ecosystems, could shift from net accretion toward net dissolution in the coming centuries.

However, extrapolating these sensitivities from the laboratory to future ocean acidification is difficult because the chemical environments of coral reefs often differ greatly from the surrounding open ocean. Metabolism by benthic communities strongly modulates reef-water carbonate chemistry (Kinsey, 1985), in some cases resulting in changes in $\left[\mathrm{CO}_{3}^{2-}\right]$ greater than those predicted for open-ocean waters by the end of this century (Shaw et al., 2012). Multiple studies have taken advantage of this natural variability to investigate the sensitivity of net ecosystem calcification (NEC) to reef-water $\left[\mathrm{CO}_{3}^{2-}\right]$, and the observed relationships have been used to predict when reefs will begin net dissolving (Shamberger et al., 2011; Shaw et al., 2012). However, recent studies have shown that NEC and reef-water $\left[\mathrm{CO}_{3}^{2-}\right]$ correlate because they both oscillate diurnally, but these correlations are unlikely to provide reliable estimates of the sensitivity of NEC to future open-ocean acidification (Andersson and Mackenzie, 2011; McMahon et al., 2013). These realizations have sparked the need for a new paradigm to investigate the sensitivity of coral reefs to ocean acidification. Rather than extrapolate NEC and $\left[\mathrm{CO}_{3}^{2-}\right]$ correlations into the future, we must first understand how community metabolism differentiates reef-water chemistry from that of the open ocean, and then factor potential changes in metabolic performance into predictions of coral reef futures. 


\subsection{Thesis objectives}

I employed a multi-faceted approach to investigate coral biomineralization and coral reef $\mathrm{CaCO}_{3}$ budgets. Overall, this thesis aims to answer the following questions:

1. Corals accrete their skeletons from an isolated calcifying fluid. What is the chemical composition of this fluid?

2. How does the geochemistry of coral skeleton reflect seawater temperature?

3. Are coral reef $\mathrm{CaCO}_{3}$ budgets sensitive to seawater $\mathrm{pH}$, and if so, how might these budgets change in the future?

4. How do chemical and thermal environments of coral reef waters differ from the open ocean, and what are the processes driving these differences?

In Chapter 2, I conducted laboratory experiments to test the influence of temperature and carbonate chemistry on $\mathrm{U} / \mathrm{Ca}$ partitioning between abiogenic aragonite and seawater. Aragonite crystals were nucleated from seawater with modified carbonate chemistry ( $\mathrm{pH} 7.8-9.0$ and carbonate ion concentrations of $600-2600 \mu \mathrm{mol} \mathrm{kg}{ }^{-1}$ ) and temperature $\left(20-40{ }^{\circ} \mathrm{C}\right)$, and the elemental composition of the precipitated aragonite was measured with mass spectrometry. While the temperature dependence of aragonite $\mathrm{Sr} / \mathrm{Ca}$ was consistent with previous experiments, $\mathrm{U} / \mathrm{Ca}$ was insensitive to temperature. Rather, U/Ca was strongly controlled by the fluid $\left[\mathrm{CO}_{3}^{2-}\right]$. Within the framework of these experimental results, I developed a model of the coral biomineralization process constrained by measured coral skeletal U/Ca ratios. The model reveals that carbonate ion concentrations of the coral calcifying fluid are elevated to several times those of ambient seawater. These findings provide new insight into the mechanism of coral calcification and the chemical composition of the calcifying fluid. The model also makes predictions regarding the correlations among the elemental and isotopic ratios of the skeleton and seawater temperature, predictions that I test in Chapter 3.

In Chapter 3, I present a novel approach to coral paleothermometry. The model developed in Chapter 2 suggests that corals precipitate aragonite crystals - and thus, 
drive Rayleigh fractionation - by elevating $\left[\mathrm{CO}_{3}^{2-}\right]$ at the site of calcification, and the experimental evidence from Chapter 2 indicates that this process is recorded in skeletal U/Ca ratios. Because U/Ca ratios are insensitive to temperature, but strongly dependent on $\left[\mathrm{CO}_{3}^{2-}\right]$, they should account for the effects of Rayleigh fractionation on $\mathrm{Sr} / \mathrm{Ca}$ ratios. I test this prediction with 14 corals collected from the Pacific Ocean and the Red Sea. I show that by utilizing coral skeleton $\mathrm{Sr} / \mathrm{Ca}$ and $\mathrm{U} / \mathrm{Ca}$ ratios in tandem, the accuracy of reconstructed temperature is $\pm 0.5^{\circ} \mathrm{C}$, which is at least twice the accuracy based on $\mathrm{Sr} / \mathrm{Ca}$ ratios alone. This chapter also serves as an additional test of the biomineralization mechanism described in Chapter 2, providing further support and insight into how corals exert control on the carbonate chemistry at the site of calcification to achieve rapid skeletal accretion.

Chapter 4 moves to the scale of coral reef ecosystems with an in situ field investigation into the sensitivity of coral bioerosion to carbonate chemistry and nutrients. I developed an automated software program to quantify rates of coral calcification and bioerosion from computerized tomography (CT) scans of coral skeletal cores (DeCarlo and Cohen, 2016). Using this program, I quantified bioerosion rates in more than 100 skeletal cores collected from 11 reef locations across the Pacific Ocean, spanning natural gradients in nutrients and $\left[\mathrm{CO}_{3}^{2-}\right]$. I found that bioerosion rates were elevated, synergistically, by high nutrients and low $\left[\mathrm{CO}_{3}^{2-}\right]$. These findings imply that future ocean acidification is likely to cause elevated rates of bioerosion, especially for reefs located within nutrient-rich regions of the ocean or with local sources of nutrients such as upwelling or terrestrial input.

In Chapter 5, I investigate the interactive relationship between benthic community metabolism and reef-water carbonate chemistry. I measured rates of net community calcification (NEC) and productivity (NEP) on Dongsha Atoll in the South China Sea. I found that reef water carbonate chemistry and community metabolism are intrinsically linked, and are influenced by community structure and thermal stress. The Dongsha Atoll NEC rate during June 2014 was greater than that measured on any other coral reef studied to date. These high calcification rates occur under daytime reef water $\left[\mathrm{CO}_{3}^{2-}\right]$ of $350 \mu \mathrm{mol} \mathrm{kg}{ }^{-1}$, substantially elevated above that of the 
surrounding open-ocean as a result of high daytime NEP, likely driven by abundant benthic algae and seagrass communities. These findings show the critical influence that reef communities themselves often have on reef water carbonate chemistry, an effect that will strongly modulate the ecosystem response to open-ocean acidification anticipated over the coming centuries.

In Chapter 6, I show the consequences of locally amplified thermal stress on a shallow coral reef community. During June 2015, a $2{ }^{\circ} \mathrm{C}$ open-ocean anomaly in the South China Sea was amplified on the shallow reef flat of Dongsha Atoll under

unusually calm weather and water flow conditions to reach temperatures $6{ }^{\circ} \mathrm{C}$ above normal. As a consequence, mass coral bleaching ensued and led to 50\% mortality of the resident coral community. Based on stress banding visualized in CT scans of century-old corals collected from this location, the extreme thermal stress event appears unprecedented over at least the past 40 years. Like chemical environments, thermal regimes on shallow reef platforms often differ greatly from the open ocean. Local reef heat budgets will modulate the open-ocean warming and have potential to amplify or depress the rate of warming, and thus may shorten or lengthen the time available for corals to acclimate and adapt.

\section{Bibliography}

Al-Horani, F. A., Al-Moghrabi, S. M., De Beer, D., 2003. The mechanism of calcification and its relation to photosynthesis and respiration in the scleractinian coral Galaxea fascicularis. Marine Biology 142 (3), 419-426.

Albright, R., Caldeira, L., Hosfelt, J., Kwiatkowski, L., Maclaren, J. K., Mason, B. M., Nebuchina, Y., Ninokawa, A., Pongratz, J., Ricke, K. L., Rivlin, T., Schneider, K., Sesboüé, M., Shamberger, K., Silverman, J., Wolfe, K., Zhu, K., Caldeira, K., 2016. Reversal of ocean acidification enhances net coral reef calcification. Nature $531,362-365$.

Alpert, A. E., Cohen, A. L., Oppo, D. W., DeCarlo, T. M., Gove, J. M., Young, C. W., 2016. Comparison of equatorial Pacific sea surface variability and trends with $\mathrm{Sr} / \mathrm{Ca}$ records from multiple corals. Paleoceanography 31, 252-265.

Andersson, A. J., Mackenzie, F. T., 2011. Ocean acidification: setting the record straight. Biogeosciences Discussions 8, 6161-6190. 
Barnes, D. J., 1970. Coral skeletons: an explanation of their growth and structure. Science 170 (3964), 1305-1308.

Cai, W.-J., Ma, Y., Hopkinson, B. M., Grottoli, A. G., Warner, M. E., Ding, Q., Hu, X., Yuan, X., Schoepf, V., Xu, H., Han, C., Melman, T. F., Hoadley, K. D., Pettay, D. T., Matsui, Y., Baumann, J. H., Levas, S., Ying, Y., Wang, Y., 2016. Microelectrode characterization of coral daytime interior $\mathrm{pH}$ and carbonate chemistry. Nature communications 7, 11144.

Chan, N. C. S., Connolly, S. R., 2013. Sensitivity of coral calcification to ocean acidification: a meta-analysis. Global Change Biology 19 (1), 282-290.

Cobb, K. M., Charles, C. D., Cheng, H., Edwards, R. L., 2003. El Nino/Southern Oscillation and tropical Pacific climate during the last millennium. Nature 424 (6946), $271-276$.

Cohen, A. L., Gaetani, G. A., Lundälv, T., Corliss, B. H., George, R. Y., 2006. Compositional variability in a cold-water scleractinian, Lophelia pertusa: new insights into 'vital effects'. Geochemistry Geophysics Geosystems 7 (12), Q12004.

Cohen, A. L., McConnaughey, T. A., 2003. Geochemical Perspectives on Coral Mineralization. Rev. Mineral. Geochem. 54 (1), 151-187.

de Villiers, S., Shen, G. T., Nelson, B. K., 1994. The -temperature relationship in coralline aragonite: Influence of variability in and skeletal growth parameters. Geochimica et Cosmochimica Acta 58 (1), 197-208.

DeCarlo, T. M., Cohen, A. L., 2016. coralCT: software tool to analyze computerized tomography (CT) scans of coral skeletal cores for calcification and bioerosion rates. URL http: //zenodo.org/record/57855

DeLong, K. L., Quinn, T. M., Shen, C., Lin, K., 2010. A snapshot of climate variability at Tahiti at $9.5 \mathrm{ka}$ using a fossil coral from IODP Expedition 310. Geochemistry Geophysics Geosystems 11 (6), Q06005.

DeLong, K. L., Quinn, T. M., Taylor, F. W., Shen, C., Lin, K., 2013. Improving coralbase paleoclimate reconstructions by replicating 350years of coral $\mathrm{Sr} / \mathrm{Ca}$ variations. Palaeogeography, Palaeoclimatology, Palaeoecology 373, 6-24.

Djogic, R., Sipos, L., Branica, M., 1986. Characterization of uranium (VI) in seawater. Limnology and Oceanography, 1122-1131.

Feely, R. A., Doney, S. C., Cooley, S. R., 2009. Ocean acidification: present conditions and future changes in a high-CO2 world. Oceanography 22 (4), 37-47.

Felis, T., Suzuki, A., Kuhnert, H., Dima, M., Lohmann, G., Kawahata, H., 2009. Subtropical coral reveals abrupt early-twentieth-century freshening in the western North Pacific Ocean. Geology 37 (6), 527-530. 
Frieler, K., Meinshausen, M., Golly, A., Mengel, M., Lebek, K., Donner, S. D., HoeghGuldberg, O., 2012. Limiting global warming to $2 \mathrm{C}$ is unlikely to save most coral reefs. Nature Climate Change 3 (2), 165-170.

Gaetani, G. A., Cohen, A. L., 2006. Element partitioning during precipitation of aragonite from seawater: A framework for understanding paleoproxies. Geochimica et cosmochimica acta 70 (18), 4617-4634.

Gaetani, G. A., Cohen, A. L., Wang, Z., Crusius, J., 2011. Rayleigh-Based, MultiElement Coral Thermometry: a Biomineralization Approach to Developing Climate Proxies. Geochimica et cosmochimica acta 75, 1920-1932.

Gagnon, A. C., Adkins, J. F., Erez, J., 2012. Seawater transport during coral biomineralization. Earth and Planetary Science Letters 329, 150-161.

Glynn, P. W., 1997. Bioerosion and coral-reef growth: a dynamic balance. Life and death of coral reefs, 68-95.

Grove, C. A., Kasper, S., Zinke, J., Pfeiffer, M., GarbeâǍ̌̌Schonberg, D., Brummer, G. A., 2013. Confounding effects of coral growth and high SST variability on skeletal Sr/Ca: implicatiaons for coral paleothermometry. Geochemistry, Geophysics, Geosystems 14 (4), 1277-1293.

Hereid, K. A., Quinn, T. M., Okumura, Y. M., 2013. Assessing spatial variability in El Niño-Southern Oscillation event detection skill using coral geochemistry. Paleoceanography.

Hoegh-Guldberg, O., Mumby, P. J., Hooten, A. J., Steneck, R. S., Greenfield, P., Gomez, E., Harvell, C. D., Sale, P. F., Edwards, A. J., Caldeira, K., 2007. Coral reefs under rapid climate change and ocean acidification. Science 318 (5857), 17371742 .

Holcomb, M., Cohen, A. L., Gabitov, R. I., Hutter, J. L., 2009. Compositional and morphological features of aragonite precipitated experimentally from seawater and biogenically by corals. Geochimica et cosmochimica acta 73 (14), 4166-4179.

Karnauskas, K. B., Cohen, A. L., Drenkard, E. J., 2015. Comment on "Equatorial Pacific coral geochemical records show recent weakening of the Walker circulation" by J. Carilli et al. Paleoceanography 30 (5), 570-574.

Kinsey, D. D., 1985. Metabolism, calcification and carbon production. I. System level studies.

Kinsman, D. J. J., Holland, H. D., 1969. The co-precipitation of cations with CaCO3IV. The co-precipitation of Sr2+ with aragonite between 16 and 96 C. Geochimica et cosmochimica acta $33(1), 1-17$. 
Langdon, C., Atkinson, M. J., 2005. Effect of elevated pCO2 on photosynthesis and calcification of corals and interactions with seasonal change in temperature/irradiance and nutrient enrichment. Journal of Geophysical Research 110 (C9), C09S07.

Marshall, J. F., McCulloch, M. T., 2002. An assessment of the Sr/Ca ratio in shallow water hermatypic corals as a proxy for sea surface temperature. Geochimica et cosmochimica acta 66 (18), 3263-3280.

McConnaughey, T., 1989a. 13C and 180 isotopic disequilibrium in biological carbonates: I. Patterns. Geochimica et Cosmochimica Acta 53 (1), 151-162.

McConnaughey, T., 1989b. 13C and 180 isotopic disequilibrium in biological carbonates: II. In vitro simulation of kinetic isotope effects. Geochimica et Cosmochimica Acta 53 (1), 163-171.

McCulloch, M., Trotter, J., Montagna, P., Falter, J., Dunbar, R., Freiwald, A., Försterra, G., López Correa, M., Maier, C., Rüggeberg, A., 2012. Resilience of cold-water scleractinian corals to ocean acidification: Boron isotopic systematics of $\mathrm{pH}$ and saturation state up-regulation. Geochimica et cosmochimica acta 87, $21-34$.

McMahon, A., Santos, I. R., Cyronak, T., Eyre, B. D., 2013. Hysteresis between coral reef calcification and the seawater aragonite saturation state. Geophysical Research Letters 40 (17), 4675-4679.

Meehl, G. A., Washington, W. M., Arblaster, J. M., Hu, A., Teng, H., Tebaldi, C., Sanderson, B. N., Lamarque, J.-F., Conley, A., Strand, W. G., White, J. B., 2012. Climate System Response to External Forcings and Climate Change Projections in CCSM4. Journal of Climate 25 (11), 3661-3683.

Palumbi, S. R., Barshis, D. J., Traylor-Knowles, N., Bay, R. A., 2014. Mechanisms of Reef Coral Resistance to Future Climate Change. Science 344, 895-898.

Pandolfi, J. M., Connolly, S. R., Marshall, D. J., Cohen, A. L., 2011. Projecting coral reef futures under global warming and ocean acidification. Science 333 (6041), 418422.

Ries, J. B., 2011. A physicochemical framework for interpreting the biological calcification response to $\mathrm{CO} 2$-induced ocean acidification. Geochimica et cosmochimica acta 75 (14), 4053-4064.

Rollion-Bard, C., Blamart, D., Trebosc, J., Tricot, G., Mussi, A., Cuif, J. P., 2011. Boron isotopes as pH proxy: A new look at boron speciation in deep-sea corals using 11B MAS NMR and EELS. Geochimica et cosmochimica acta 75 (4), 1003-1012.

Saenger, C., Cohen, A. L., Oppo, D. W., Hubbard, D., 2008. Interpreting sea surface temperature from strontium/calcium ratios in Montastrea corals: Link with growth rate and implications for proxy reconstructions. Paleoceanography 23 (3), PA3102. 
Shamberger, K. E. F., Feely, R. A., Sabine, C. L., Atkinson, M. J., DeCarlo, E. H., Mackenzie, F. T., Drupp, P. S., Butterfield, D. A., 2011. Calcification and organic production on a Hawaiian coral reef. Marine Chemistry 127 (1), 64-75.

Shaw, E. C., McNeil, B. I., Tilbrook, B., 2012. Impacts of ocean acidification in naturally variable coral reef flat ecosystems. Journal of Geophysical Research: Oceans 117 (C3), C03038.

Smith, S. V., Buddemeier, R. W., Redalje, R. C., Houck, J. E., 1979. Strontiumcalcium thermometry in coral skeletons. Science 204 (4391), 404-7.

Stearn, C. W., Scoffin, T. P., Martindale, W., 1977. Calcium Carbonate Budget of a Fringing Reef on the West Coast of Barbados Part I-Zonation and Productivity. Bulletin of Marine Science 27 (3), 479-510.

Stocker, T. F., Qin, D., Plattner, G. K., Tignor, M., Allen, S. K., Boschung, J., Nauels, A., Xia, Y., Bex, V., Midgley, P. M., 2013. IPCC, 2013: Summary for Policymakers. In Climate Change 2013: The Physical Science Basis. Tech. rep.

Storz, D., Gischler, E., Fiebig, J., Eisenhauer, A., Garbe-Schönberg, D., 2013. Evaluation of oxygen isotope and $\mathrm{Sr} / \mathrm{Ca}$ ratios from a Maldivian scleractinian coral for reconstruction of climate variability in the northwestern Indian Ocean. Palaios 28 (1), $42-55$.

Tambutté, E., Tambutté, S., Segonds, N., Zoccola, D., Venn, A., Erez, J., Allemand, D., 2012. Calcein labelling and electrophysiology: insights on coral tissue permeability and calcification. Proceedings of the Royal Society B: Biological Sciences 279 (1726), 19-27.

Tierney, J. E., Abram, N. J., Anchukaitis, K. J., Evans, M. N., Giry, C., Kilbourne, K. H., Saenger, C. P., Wu, H. C., Zinke, J., 2015. Tropical sea surface temperatures for the past four centuries reconstructed from coral archives. Paleoceanography 30, $226-252$.

Toth, L. T., Aronson, R. B., Cobb, K. M., Cheng, H., Edwards, R. L., Grothe, P. R., Sayani, H. R., 2015. Climatic and biotic thresholds of coral-reef shutdown. Nature Climate Change 5, 369-374.

Trotter, J., Montagna, P., McCulloch, M., Silenzi, S., Reynaud, S., Mortimer, G., Martin, S., Ferrier-Pagès, C., Gattuso, J. P., Rodolfo-Metalpa, R., 2011. Quantifying the $\mathrm{pH}$ 'vital effect' in the temperate zooxanthellate coral Cladocora caespitosa: Validation of the boron seawater pH proxy. Earth and Planetary Science Letters 303 (3), 163-173.

van Hooidonk, R., Maynard, J. A., Planes, S., 2013. Temporary refugia for coral reefs in a warming world. Nature Climate Change 3, 508-511. 
Venn, A., Tambutte, E., Holcomb, M., Allemand, D., Tambutte, S., 2011. Live tissue imaging shows reef corals elevate $\mathrm{pH}$ under their calcifying tissue relative to seawater. PLoS One 6 (5), e20013.

Wisshak, M., Schönberg, C. H. L., Form, A., Freiwald, A., 2012. Ocean Acidification Accelerates Reef Bioerosion. PLoS One 7 (9), e45124.

Wu, H. C., Moreau, M., Linsley, B. K., Schrag, D. P., Corrège, T., 2014. Investigation of sea surface temperature changes from replicated coral $\mathrm{Sr} / \mathrm{Ca}$ variations in the eastern equatorial Pacific (Clipperton Atoll) since 1874. Palaeogeography, Palaeoclimatology, Palaeoecology 412, 208-222. 


\section{Chapter 2}

\section{Experimental determination of factors controlling $\mathrm{U} / \mathrm{Ca}$ of aragonite precipitated from seawater}

\section{$2.1 \quad$ Abstract}

The $\mathrm{U} / \mathrm{Ca}$ ratio of aragonite coral skeleton exhibits coherent patterns of seasonal and interannual variability. In field-sampled corals and those grown in controlled culture experiments, strong correlations have been found between coral skeleton $\mathrm{U} / \mathrm{Ca}$ and water temperature, $\mathrm{pH}$, carbonate ion concentration, and salinity. However, the mechanism(s) underlying these different correlations remain unclear. We performed abiogenic precipitation experiments designed to evaluate the sensitivity of $U$ partitioning between aragonite and seawater to temperature, $\mathrm{pH}$, and the concentration of carbonate ion in seawater. Aragonite was precipitated from seawater by addition of carbonate alkalinity at rates set to maintain stable carbonate chemistry during precipitation. Experiments were conducted at $20-40{ }^{\circ} \mathrm{C}$, with $\mathrm{pH}$ 7.8-9.0 and carbon-

DeCarlo T.M., Gaetani G.A., Holcomb M., Cohen A.L., 2015. Experimental determination of factors controlling $\mathrm{U} / \mathrm{Ca}$ of aragonite precipitated from seawater: implications for interpreting coral skeleton. Geochimica et Cosmochimica Acta 162, 151-165. 
ate ion concentrations of $600-2600 \mu \mathrm{mol} \mathrm{kg} \mathrm{kg}^{-1}$. U/Ca ratios of the bulk precipitate and fluid were determined by inductively coupled plasma mass spectrometry. Our results show that the $\mathrm{U} / \mathrm{Ca}$ ratio of aragonite precipitated from seawater decreases with increasing carbonate ion concentration, and is independent of $\mathrm{pH}$ and temperature. We use these results as a framework to interpret the skeletal composition of coral aragonite precipitated from a calcifying fluid that is semi-isolated from the external seawater environment. Accordingly, coral U/Ca ratios are consistent with calcifying fluid carbonate ion concentrations that are several times greater than those of ambient seawater. Correlations between coral U/Ca ratios and seawater temperature, carbonate chemistry, and other environmental variables arise indirectly, via the impacts of these variables on the carbonate ion concentration of the coral calcifying fluid.

\subsection{Introduction}

Trace element-to-calcium ratios $(\mathrm{E} / \mathrm{Ca})$ in the skeletons of scleractinian corals, both deep and surface dwelling, are widely used as proxies for environmental conditions in the oceans. The uranium-to-calcium ratio $(\mathrm{U} / \mathrm{Ca})$ of coral skeleton exhibits strong seasonality and covaries with other E/Ca ratios (Cardinal et al., 2001; Quinn and Sampson, 2002; Sinclair, 2005; Felis et al., 2009). In skeletons from field-sampled corals and those grown in controlled culture experiments, strong correlations have been found between U/Ca and crystal morphology (Robinson et al., 2006), seawater temperature (Min et al., 1995; Felis et al., 2009; Armid et al., 2011), pH (Inoue et al., 2011; Raddatz et al., 2014), carbonate ion concentration $\left(\left[\mathrm{CO}_{3}^{2-}\right]\right)$ (Shen and Dunbar, 1995; Armid et al., 2008; Anagnostou et al., 2011), and salinity (Ourbak et al., 2006). The $\mathrm{U} / \mathrm{Ca}$ ratio of the calcite shells of foraminifera grown in the laboratory also reflect sensitivites to seawater carbonate chemistry (Russell et al., 2004; Keul et al., 2013). However, on the basis of existing data it is not possible to demonstrate conclusively which - if any - of these factors is directly responsible for $\mathrm{U} / \mathrm{Ca}$ variability.

Observations of a link between aragonite $\mathrm{U} / \mathrm{Ca}$ and seawater carbonate chemistry 
plausibly reflect the speciation of uranyl ion $\left(\mathrm{UO}_{2}^{2+}\right)$, which forms different complexes with $\mathrm{CO}_{3}^{2-}$ in seawater as a function of $\mathrm{pH}$ (Djogic et al., 1986) and/or $\left[\mathrm{CO}_{3}^{2-}\right]$ (Kitano and Oomori, 1971; Saito and Miyauchi, 1982; Keul et al., 2013). Uranyl speciation is potentially influenced by other factors in addition to carbonate chemistry. In freshwater at low ionic strength $(\mathrm{I}=0.1$, whereas for seawater $\mathrm{I}=0.7), \mathrm{UO}_{2}^{2+}$ forms complexes with both $\mathrm{Ca}^{2+}$ and $\mathrm{CO}_{3}^{2-}\left(\mathrm{CaUO}_{2}\left(\mathrm{CO}_{3}\right)_{3}^{2-}\right.$ and $\left.\mathrm{Ca}_{2} \mathrm{UO}_{2}\left(\mathrm{CO}_{3}\right)_{3}\right)$ (Dong and Brooks, 2006; Endrizzi and Rao, 2014), and - at pH less than 8 or in estuarine waters - with dissolved organic matter (DOM) (Mann and Wong, 1993; Gustafsson et al., 2009). Nevertheless, several studies have found that the dominant uranyl complex in seawater at $\mathrm{pH} 8$ is uranyl tricarbonate $\left(\mathrm{UO}_{2}\left(\mathrm{CO}_{3}\right)_{3}^{4-}\right)$ (Saito and Miyauchi, 1982; Djogic et al., 1986; Kalin et al., 2005), which was found to be incorporated directly into the aragonite lattice, substituting for $\mathrm{CO}_{3}^{2-}$ rather than $\mathrm{Ca}^{2+}$ (Reeder et al., 2000). Because the abundance of $\mathrm{UO}_{2}\left(\mathrm{CO}_{3}\right)_{3}^{4-}$ in seawater varies with $\mathrm{pH}$ and/or $\left[\mathrm{CO}_{3}^{2-}\right]$, the $\mathrm{U} / \mathrm{Ca}$ ratio of aragonite should be sensitive to one or both of these carbonate system variables.

Abiogenic precipitation experiments provide a means to investigate environmental controls on element partitioning between aragonite and seawater in the absence of physiological processes that can mask their influence. For example, Meece and Benninger (1993) used this approach to investigate the incorporation of a series of radionuclides into abiogenic aragonite precipitated from seawater at room temperature. Results from these experiments indicate that the aragonite-seawater exchange coefficient for $\mathrm{U} / \mathrm{Ca}\left(K_{D}^{U / C a}=\left(C_{\text {solid }}^{U} / C_{\text {solid }}^{C a}\right) /\left(C_{\text {fluid }}^{U} / C_{\text {fluid }}^{C a}\right)\right.$ where $C_{j}^{i}$ is the concentration of $i$ in phase $j$ ) decreases with increasing $\mathrm{pH}$ and/or precipitation rate. However, the relative importance of these two variables could not be resolved, and the influence of temperature was not evaluated. Gabitov et al. (2008) found that at relatively low pH (7.6-8), the $K_{D}^{U / C a}$ of abiogenic aragonite increases with increasing precipitation rate and temperature. This precipitation rate dependence at low $\mathrm{pH}$ is opposite in sign to that found by Meece and Benninger (1993) at higher $\mathrm{pH}$ (8.0-8.8). As with the Meece and Benninger (1993) experiments, Gabitov et al. (2008) did not isolate temperature, $\mathrm{pH},\left[\mathrm{CO}_{3}^{2-}\right]$, and precipitation rate, making it difficult to determine conclusively which 
factors control U partitioning between aragonite and seawater. Here, we present results from abiogenic aragonite precipitation experiments designed to investigate the relative influence of temperature $(T), \mathrm{pH}$, and $\left[\mathrm{CO}_{3}^{2-}\right]$ on the $\mathrm{U} / \mathrm{Ca}$ ratio of aragonite precipitated from seawater. We use these results to develop a biomineralization model that provides a framework for interpreting the $\mathrm{U} / \mathrm{Ca}$ ratio of coral skeleton and its variability.

\subsection{Experimental and analytical methods}

\subsubsection{Precipitation experiments}

The seawater used in our experiments was collected from Vineyard Sound, Massachusetts, passed through a $0.2 \mu \mathrm{m}$ filter, and stored in the dark. A concentrated seawater solution was prepared by evaporating an aliquot of filtered seawater to half of its initial mass and passing it through a $0.45 \mu \mathrm{m}$ HAWP filter. The measured concentration of $\mathrm{Ca}^{2+}$ in the twice-concentrated seawater was approximately twice that measured in the

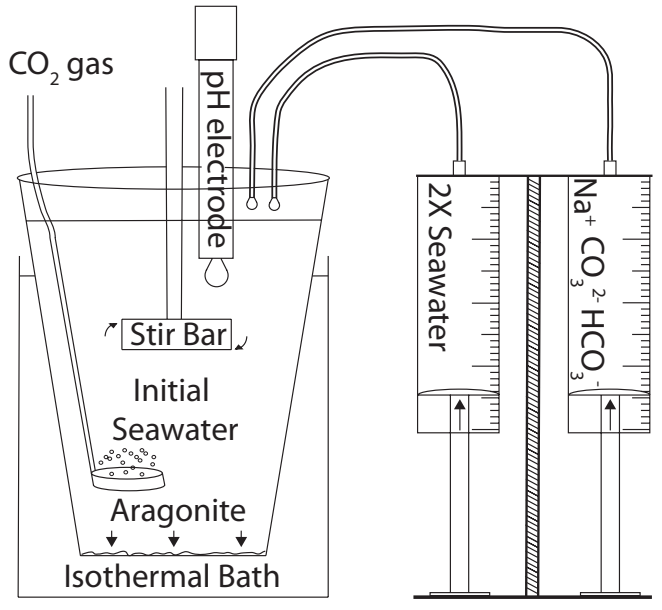

Figure 2-1: Schematic diagram of experimental setup.

filtered seawater (Table 2.1), indicating

that $\mathrm{CaCO}_{3}$ did not precipitate from the concentrated seawater. Solutions containing carbonate alkalinity (hereafter referred to as $\mathrm{Na}$ solutions) were prepared by dissolving $\mathrm{Na}_{2} \mathrm{CO}_{3}$ and/or $\mathrm{NaHCO}_{3}$ powders in deionized water to achieve approximately $0.04 \mathrm{M} \mathrm{Na}_{2} \mathrm{CO}_{3}, 0.1 \mathrm{M} \mathrm{NaHCO}_{3}$, or a 1:1 combination of these two solutions (Table 2.1). A seawater solution containing elevated $\mathrm{Ca}$ and $\mathrm{Sr}$ concentrations was prepared by dissolving $\mathrm{CaCO}_{3}$ and $\mathrm{SrCO}_{3}$ powders in filtered seawater that had first been acidified by bubbling with $\mathrm{CO}_{2}$ gas. This modified seawater solution was then 


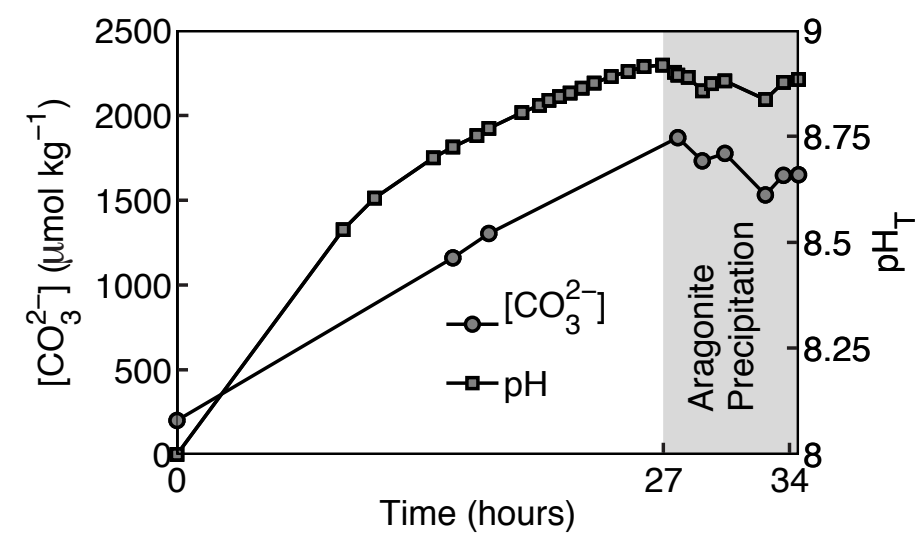

Figure 2-2: Evolution of solution pH (squares) and $\left[\mathrm{CO}_{3}^{2-}\right]$ (circles) during one experiment ("h01" - see Table 2). Shaded background indicates when aragonite precipitated during the experiment.

passed through a $0.45 \mu \mathrm{m}$ HAWP filter and divided into two aliquots, one of which (g13 acidified seawater) was spiked with $\mathrm{NaHCO}_{3}$ (batch 4) to $4 \%$ by volume to elevate the initial TA (Table 2.1).

Precipitation experiments were conducted at $20-40{ }^{\circ} \mathrm{C}$ as follows. First, between 400 and $800 \mathrm{~g}$ of seawater was added to a $1 \mathrm{~L}$ polypropylene container, placed into an isothermal bath, and stirred continuously at 120 or $130 \mathrm{rpm}$ (Fig. 2-1). For the majority of the experiments, the concentrated seawater solution and one of the $\mathrm{Na}$ solutions were added simultaneously to the filtered seawater at a constant rate using a Kd Scientific syringe pump. The initiation of aragonite precipitation was indicated by a decrease in the $\mathrm{pH}$ of the seawater solution (Fig. 2-2). Once precipitation began, only $\mathrm{Na}_{2} \mathrm{CO}_{3}$ solution and concentrated seawater were added, regardless of which $\mathrm{Na}$ solution was initially used. Different combinations of initial pumping rates (between 0.06 and $10 \mathrm{~mL} \mathrm{hr}^{-1}$ ) and different $\mathrm{Na}$ solutions (Table 2.1) added to seawater controlled the $\mathrm{pH}$ and $\left[\mathrm{CO}_{3}^{2-}\right]$ of the seawater solution when precipitation began. In order to maintain stable carbonate chemistry during aragonite precipitation, pumping rates were regularly adjusted so that addition balanced removal by precipitation. Several of the experiments (g10, g11, and h09) were bubbled with a hydrated mixture of air containing 400-5000 $\mathrm{ppm} \mathrm{CO}_{2}$ at $25 \mathrm{~mL} \mathrm{~min}^{-1}$ in order to stabilize $p \mathrm{CO}_{2}$ and thus maintain $\mathrm{pH}$ in the beaker at levels below that of seawater. Two experiments (g13 and f08) were conducted by pumping Ca- and Sr-enriched seawater solution (Table 2.1) rather than concentrated seawater and $\mathrm{Na}$ solution - and were bubbled with hydrated 
air at $25 \mathrm{~mL} \mathrm{~min}{ }^{-1}$ in order to strip $\mathrm{CO}_{2}$ from the experimental solution. Over the course of each experiment, 8-10 samples of approximately $25 \mathrm{~g}$ each were typically collected for analysis of total alkalinity (TA). Each experiment was terminated after addition of approximately $100 \mathrm{~g}$ of $\mathrm{Na}_{2} \mathrm{CO}_{3}$ solution during aragonite precipitation. The final experimental solution was passed through a $0.45 \mu \mathrm{m}$ HAWP filter and precipitate retained on the filter rinsed with deionized water and ethanol. Precipitate on the beaker, stir rod, and bubbler was gently removed with a metal spatula. An aliquot of the final solution was analyzed for TA, pH, salinity, and the concentrations of $\mathrm{Ca}, \mathrm{Sr}$, and $\mathrm{U}$.

The $T$ of each experiment was continuously monitored (varying within $\pm 0.1^{\circ} \mathrm{C}$ about the reported temperature during each experiment), and the $\mathrm{pH}$ of the experimental solution was regularly measured as follows. Approximately 7-8 g of experimental solution were removed and divided into two aliquots; one was used to rinse the electrode and the second to make a $\mathrm{pH}$ measurement of the solution while held at $25.5^{\circ} \mathrm{C}$ and stirred with a magnetic stir bar. The electrode was calibrated against NBS (now NIST) buffers; this calibration was converted to the total $\mathrm{pH}$ scale $\left(\mathrm{pH}_{T}\right)$ through comparison of the intercept of the $\mathrm{mV}-\mathrm{pH}$ regression (i.e. a constant offset was applied) to reference seawater provided by the laboratory of Andrew Dickson (batch 116; Scripps Institution of Oceanography).

Total alkalinity of initial seawater, experimental solutions, and $\mathrm{Na}$ solutions were determined by titrating $1 \mathrm{~g}$ of sample (measured to $\pm 0.0001 \mathrm{~g}$ ) with $0.01 \mathrm{M} \mathrm{HCl}$, following the technique of Holcomb et al. (2012). Concentration of the acid was calibrated by titrating reference seawater of known alkalinity provided by the laboratory of Andrew Dickson (batch 116; Scripps Institution of Oceanography). Samples

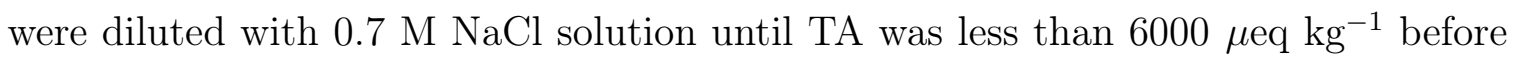
triplicate titrations, and TA was calculated by a non-linear least squares regression (Holcomb et al., 2012). At each sampling point, the expected solution TA was calculated from all equivalents of alkalinity added (initial seawater, concentrated seawater, and $\mathrm{Na}$ solutions) and removed (sample collection) from the experiment. Alkalinity anomaly was quantified as the difference between measured and calculated TA. The 
full carbonate chemistry of the experimental solution was calculated from $\mathrm{pH}_{T}$ (at the $T$ of the experiment) and TA using the program CO2SYS (Lewis et al., 1998), with acidity constants of Mehrbach (1973) refit by Dickson and Millero (1987).

Salinities of stock filtered seawater and final experimental solutions were measured using a Guildline autosal (accuracy \pm 0.003 ) calibrated with IAPSO standard seawater (batch P-153). The salinity of the initial filtered seawater was 31.785. There was typically an increase in salinity of 0.5-1 PSU between the beginning and end of each experiment (Table 2.2), which was attributed to evaporation and/or addition of $\mathrm{Na}^{+}$ from $\mathrm{Na}$ solutions. Salinity at solution sampling points was interpolated with respect to time between initial and final salinity measurements. Prior to analysis, approximately $100 \mu \mathrm{g}$ of precipitate was suspended in deionized water, centrifuged, and the supernatant removed. This cleaning step was performed in triplicate. A second set of subsamples was processed separately for $\mathrm{U} / \mathrm{Ca}$ measurements. A duplicate washing of approximately $100 \mu \mathrm{g}$ sample with $0.75 \mathrm{~mL}$ of $0.02 \mathrm{M} \mathrm{NaOH}$ solution (Fisher lot 975017) preceded duplicate deionized water washes in order to remove any adsorbed uranyl complexes.

Clean aragonite samples were dissolved in 5\% trace metal grade nitric acid before analysis by inductively coupled plasma mass spectrometry (ICP-MS). Long-term instrument precision (one standard deviation) determined on an in-house coral skeleton external consistency standard was $0.04 \mathrm{mmol} \mathrm{mol}^{-1}(0.4 \%$ relative $)$ for $\mathrm{Sr} / \mathrm{Ca}$ and $0.009 \mu \mathrm{mol} \mathrm{mol}{ }^{-1}$ (0.8\% relative) for $\mathrm{U} / \mathrm{Ca}$. Counts of ${ }^{48} \mathrm{Ca},{ }^{88} \mathrm{Sr}$, and ${ }^{238} \mathrm{U}$ were made in low-resolution on a Thermo-Finnegan Element2 ICP-MS at WHOI with 30 scans per sample and a 3-minute wash with $5 \%$ nitric acid between samples. Sample counts were corrected for background counts made on $5 \%$ nitric acid blanks, and converted to $\mathrm{Sr} / \mathrm{Ca}$ and $\mathrm{U} / \mathrm{Ca}$ ratios by calibration with the Porites coral JCp-1 standard ( $\mathrm{Sr} / \mathrm{Ca}$ of $8.838 \mathrm{mmol} \mathrm{mol}^{-1}$ and $\mathrm{U} / \mathrm{Ca}$ of $1.192 \mu \mathrm{mol} \mathrm{mol}^{-1}$ ) (Hathorne et al., 2013). We tested the homogeneity of precipitate subsamples by cleaning and analyzing five different aliquots in duplicate.

Concentrations of $\mathrm{Ca}$, $\mathrm{Sr}$, and $\mathrm{U}$ in filtered seawater, $\mathrm{Na}$ solutions, and the samples of solution collected at the end of each experiment were also determined by ICP-MS. 
High-Purity Standard simulated seawater (lot \# 1221201) was used as the primary standard for seawater and experimental solution analyses, whereas High-Purity Standards single element solutions were used for analysis of $\mathrm{Na}$ solutions. Samples and standards were spiked with ${ }^{115} \mathrm{In}$ at a concentration of $1.31 \mathrm{ppb}$ as an internal standard. Background concentrations were subtracted based on analysis of a $5 \%$ nitric acid blank. Instrument precision $(1 \sigma)$ determined from repeated measurements of NASS-5 seawater was $0.06 \mathrm{mmol} \mathrm{kg}{ }^{-1}$ (0.7\% relative) for $\mathrm{Ca}, 0.3 \mu \mathrm{mol} \mathrm{kg}^{-1}(0.4 \%$ relative) for $\mathrm{Sr}$, and $0.1 \mathrm{nmol} \mathrm{\textrm {kg } ^ { - 1 }}$ (0.9\% relative) for $\mathrm{U}$.

The mineralogy of the experimental precipitates was confirmed using Raman spectroscopy and X-ray diffraction (XRD). At least 3 grains per experiment were analyzed using a Raman microscope (Horiba Scientific LabRam HR800) with one 5-second acquisition. A subsample of each precipitate was also analyzed by XRD as follows: precipitates were loaded onto a Si holder on a rotating stage and diffraction patterns collected using a PANalytical Empyrean diffractometer (at the Centre for Microscopy, Characterisation Analysis, UWA) using Ni filtered $\mathrm{Cu} \mathrm{K} \alpha$ radiation (generator at 40 $\mathrm{kV}$, current $40 \mathrm{~mA})$.

Scanning electron microscope (SEM) images and experimental data, including solution $\mathrm{pH}$ and $\mathrm{TA}$, aragonite element ratios, fluid element concentrations, sample masses, and solution pumping rates are provided in the supplementary material.

\subsubsection{Determination of element partitioning in open-system experiments}

The equilibrium distribution of two elements, such as $\mathrm{Sr}$ and $\mathrm{Ca}$, between aragonite and fluid is described by an exchange reaction:

$$
\mathrm{Sr}^{\text {Fluid }}+\mathrm{Ca}^{\text {Aragonite }}=\mathrm{Sr}^{\text {Aragonite }}+\mathrm{Ca}^{\text {Fluid }}
$$

This reaction can be quantified through the use of a semi-empirical exchange coefficient: 
Table 2.1: Summary of elemental concentrations and alkalinity of initial seawater and $\mathrm{Na}$ solutions.

\begin{tabular}{lllll}
\hline Solution & $\begin{array}{l}{[\mathrm{Ca}]} \\
(\mathrm{mmol} \mathrm{kg}\end{array}$ & $\begin{array}{l}{[\mathrm{Sr}]} \\
(\mu \mathrm{mol} \mathrm{kg}-1)\end{array}$ & $\begin{array}{l}{[\mathrm{U}]} \\
(\mathrm{nmol} \mathrm{kg}-1)\end{array}$ & $\begin{array}{l}\mathrm{TA} \\
\left(\mu \mathrm{eq} \mathrm{kg} \mathrm{kg}^{-} 1\right)\end{array}$ \\
\hline Filtered seawater & 9.40 & 75.15 & 12.4 & $2.132(0.001) \times 10^{3}$ \\
2X seawater & 19.3 & 160.9 & 25.2 & $4.25(0.04) \times 10^{3}$ \\
g13 acidified seawater & 19.7 & 342 & 12.0 & $42.4(0.1) \times 10^{3}$ \\
f08 acidified seawater & 20.3 & 352 & 12.3 & $28.3(0.1) \times 10^{3}$ \\
Na2CO3 batch 1 & N.D. & 0.30 & N.D. & $76.8(0.2) \times 10^{3}$ \\
Na2CO3 batch 2 & N.D. & 0.28 & N.D. & $79.6(0.2) \times 10^{3}$ \\
Na2CO3 batch 3 & N.D. & 0.27 & N.D. & $79.8(0.1) \times 10^{3}$ \\
NaHCO3 batch 1 & $8.8 \times 10^{-3}$ & 0.30 & N.D. & $98.4(0.1) \times 10^{3}$ \\
NaHCO3 batch 2 & $7.3 \times 10^{-3}$ & 0.28 & N.D. & $96.8(0.3) \times 10^{3}$ \\
NaHCO3 batch 3 & $8.1 \times 10^{-3}$ & 0.29 & N.D. & $88.7(0.1) \times 10^{3}$ \\
NaHCO3 batch 4 & $8.0 \times 10^{-3}$ & 0.29 & N.D. & $115.4(0.2) \times 10^{3}$ \\
1:1 mix batch 1 & $4.4 \times 10^{-3}$ & 0.28 & N.D. & $85.9(0.5) \times 10^{3}$ \\
1:1 mix batch 2 & $3.8 \times 10^{-3}$ & 0.29 & N.D. & $88.0(0.1) \times 10^{3}$ \\
\hline
\end{tabular}

Notes: Experiments f08 and g13 were conducted by pumping acidified seawater enriched in $\mathrm{Sr}^{2+}$ and $\mathrm{Ca}^{2+}$ by dissolution of $\mathrm{SrCO}_{3}$ and $\mathrm{CaCO}_{3}$. Not detectable (N.D.) measurements defined as less than 3 times the standard deviation of prediction of concentration from ICP-MS counts for $\mathrm{Ca}$, Sr, and U, which were $2 \times 10^{-3}$ mmol kg ${ }^{-1}, 8 \times 10^{-2} \mu \mathrm{mol} \mathrm{kg}{ }^{-1}$, and $2 \times 10^{-3} \mathrm{nmol} \mathrm{kg}^{-1}$, respectively. Numbers in parentheses following TA values indicate $\pm 1 \sigma$ of at least triplicate titrations.

$$
K_{D}^{S r / C a}=\left(C_{S r} / C_{C a}\right)^{\text {Aragonite }} /\left(C_{S r} / C_{C a}\right)^{\text {Fluid }}
$$

where $\mathrm{C}_{i}$ is the molar concentration of $\mathrm{Sr}$ or $\mathrm{Ca}$ in aragonite or fluid. During closed-system precipitation of aragonite at temperatures where diffusion is too slow for the interior of the crystal to maintain equilibrium with the external fluid, exchange coefficients are determined using the Doerner-Hoskin relationship:

$$
\log \left(1+\frac{\operatorname{mol}_{S r}^{\text {Aragonite }}}{m o l_{S r}^{\text {Fluid }}}\right)=K_{D}^{S r / C a} \log \left(1+\frac{\text { mol }_{C a}^{\text {Aragonite }}}{\text { mol }_{C a}^{\text {Fluid }}}\right)
$$

where mol $_{i}^{\text {Aragonite }}$ is the total number of moles of $\mathrm{Sr}$ or $\mathrm{Ca}$ in the bulk precipitate and mol $_{i}^{\text {Fluid }}$ is the total number of moles of $\mathrm{Sr}$ or $\mathrm{Ca}$ in the final fluid (Doerner and Hoskins, 1925). Our experiments represent open-system precipitation of aragonite (i.e. the bulk composition was modified by continuous addition of concentrated 
seawater and $\mathrm{Na}$ solutions and the removal of fluid samples), so that distribution coefficients could not be determined directly from the final (measured) fluid and solid compositions. Therefore, aragonite-fluid exchange coefficients were determined through knowledge of element concentrations in the initial and final fluids, the aragonite precipitate, and all system inputs (concentrated seawater; Na solutions; Ca, Sr-enriched seawater) and outputs (fluid samples, aragonite precipitation). Change in the total number of moles of element $i$ in the solution during open-system precipitation is given by:

$\frac{d i^{\text {total }}}{d t}=\frac{d m^{\text {ConcSW }}}{d t}[i]^{\text {ConcSW }}+\frac{d m^{\text {NaSolution }}}{d t}[i]^{\text {NaSolution }}-\frac{d m^{\text {Aragonite }}}{d t}\left(K_{D}^{i / j}\right) \frac{[i]^{\text {Fluid }}}{[j]^{\text {Fluid }}}[j]^{\text {Aragonite }}$

where $i_{\text {total }}$ is the total moles of $i$ in solution, $t$ is time, $m^{k}$ is mass, and $[i]^{k}$ and $[j]^{k}$ are the concentrations $\left(\mathrm{mol} \mathrm{kg}{ }^{-1}\right)$ of $i(\mathrm{Sr}$ or $\mathrm{U})$ and $j\left(\mathrm{Ca}\right.$ or $\left.\mathrm{CO}_{3}^{2-}\right)$, respectively. The mass of aragonite precipitated per unit time $\left(\mathrm{g} \mathrm{h}^{-1}\right)$ is determined from the change in alkalinity anomaly per unit time (difference between measured TA and calculated sum of TA added, where 1 mole of aragonite precipitates per 2 equivalents of TA and where moles of aragonite are converted to mass using the molecular weight of $\mathrm{CaCO}_{3}$ ). The inventory of $\mathrm{Ca}$ is calculated from the initial measured $\mathrm{Ca}$ concentration using alkalinity anomalies, and the concentration of $\mathrm{CO}_{3}^{2-}$ in aragonite is calculated from stoichiometry. Since the initial fluid composition was measured, the concentration of element $i$ in the fluid can be solved numerically at any time $t$ using the measured rates and the concentrations for inputs and precipitate. In practice, solution samples were periodically removed, so Eq. (2.4) was integrated separately between sampling points using the Runge-Kutta method (Dormand and Prince, 1980). The number of moles of $\mathrm{Ca}, \mathrm{Sr}$, and $\mathrm{U}$ removed by each sample was calculated as the product of concentration at the time of sampling and the measured mass of the sample. Because $\left[\mathrm{CO}_{3}^{2-}\right]$ is not conservative in seawater, any change in $\left[\mathrm{CO}_{3}^{2-}\right]$ between sampling points - as determined from $\mathrm{pH}_{T}$ and $\mathrm{TA}$ - was assumed to take place at a constant rate so that $\left[\mathrm{CO}_{3}^{2-}\right]$ at any time $t$ could be interpolated between sampling points. 
The concentrations of $\mathrm{Sr}$ and $\mathrm{U}$ in the final fluid and bulk precipitate (aragonite) were used to constrain the $K_{D}^{S r / C a}$ and $K_{D}^{U / C O 3}$ values for each experiment. Forward modeling using initial guesses for $K_{D}^{S r / C a}$ and $K_{D}^{U / C O 3}$ - the only unknown variable in Eq. (2.4) - resulted in a predicted evolution for $\mathrm{Sr}$ and $\mathrm{U}$ in the fluid and the concentrations of $\mathrm{Sr}$ and $\mathrm{U}$ in the bulk aragonite. The calculated $\mathrm{Sr}$ and $\mathrm{U}$ concentrations in the final fluid and bulk aragonite were compared to the measured values, and a residual was calculated as follows:

$$
\text { residual }=\left(\frac{i_{\text {predicted }}-i_{\text {measured }}}{\epsilon_{i}}\right)_{\text {Solid }}^{2}+\left(\frac{i_{\text {predicted }}-i_{\text {measured }}}{\epsilon_{i}}\right)_{\text {Fluid }}^{2}
$$

where $i$ is the total moles of $\mathrm{Sr}$ or $\mathrm{U}$ and $\epsilon$ is the measurement uncertainty of total $\mathrm{Sr}$ or $\mathrm{U}$ in the solid or fluid. Final values for $K_{D}^{S r / C a}$ and $K_{D}^{U / C O 3}$ were determined by minimizing Eq. (2.5) separately for Sr and U using Nelder-Mead unconstrained nonlinear optimization (Lagarias et al., 1998), implemented with MATLAB 2012a. A Monte Carlo method was used to quantify the uncertainties associated with our estimates of $K_{D}^{S r / C a}$ and $K_{D}^{U / C O 3}$. The determination of $K_{D}^{S r / C a}$ and $K_{D}^{U / C O 3}$ for each experiment was repeated 1000 times, adding random measurement uncertainty ( $2 \sigma$ assuming a Gaussian distribution) to the measurements of $\mathrm{pH}_{T}$, TA, and $\mathrm{Sr}$ and $\mathrm{U}$ concentrations in the solid and fluid. Uncertainty in estimates of exchange coefficients was taken as the standard deviation of exchange coefficients from all Monte Carlo iterations. The mean and standard deviation of carbonate system parameters for each experiment were weighted by change in alkalinity anomaly between sampling points:

$$
\begin{gathered}
w_{k}=\left(\frac{A A_{k}-A A_{k-1}}{A A_{n}}\right) \\
\bar{X}=\sum_{k=1}^{n}\left[\frac{X_{k-1}+X_{k}}{2} w_{k}\right]
\end{gathered}
$$




$$
\sigma_{X}=\sqrt{\frac{\sum_{k=1}^{n}\left[\left(X_{k}-\bar{X}\right)^{2} w_{k}\right]}{(n-2) \frac{\sum_{k=1}^{n} w_{k}}{n-1}}}
$$

where $w_{k}$ is the weighting coefficient assigned to the $k$ th of $\mathrm{n}$ total samples, $k=0$ refers to the fluid prior to precipitation, $A A$ is alkalinity anomaly, $X_{k}$ is any carbonate system parameter at the $k$ th sample, and $\sigma_{X}$ is the sample standard deviation of parameter $X$. By this definition, weighting of measurements is determined by the change in alkalinity anomaly between sampling points so that the weighting coefficient represents the proportion of the bulk precipitate formed between consecutive

measurements. For this reason, the estimated means are representative of only the time during aragonite precipitation, not the entire experiment. The mean of a given parameter is then estimated as the sum of the product of the weighting coefficient and the mean measured value from each consecutive pair of samples. Likewise, the sample standard deviation is estimated with the same weighting coefficients. Mean aragonite precipitation rate per surface area $\left(\mu \mathrm{mol} \mathrm{m}{ }^{-2} \mathrm{hr}^{-1}\right)$ was estimated for each experiment using the mean aragonite saturation state $\left(\Omega_{\text {Arag }}\right)$ and $T$ of the experiment and their relationships with aragonite precipitation rate reported by Burton and Walter (1987), where precipitation rate $=k\left(\Omega_{\text {Arag }}-1\right)^{n}$ and where $k=-0.0177 T^{2}+1.47 T+14.9$ and $n=0.0628 T+0.0985$ (Table 2.2).

\subsection{Results}

\subsubsection{Precipitate mineralogy and homogeneity}

All Raman spectra taken from experimental precipitates and an aragonite standard contain a double peak in Raman shift between 700 and $708 \mathrm{~cm}^{-1}$ characteristic of aragonite (Brahmi et al., 2010), and clearly distinct from the calcite peak at $712 \mathrm{~cm}^{-1}$ (Fig. 2-3). Further, XRD patterns collected on a subsample of each experimental precipitate are consistent with aragonite and show no contaminating phases, except for a small peak near $2 \theta$ of 30 for experiment h10 (Fig. 2-3). Since this peak is very weak, only aragonite was found in the Raman spectra, crystal morphology is 

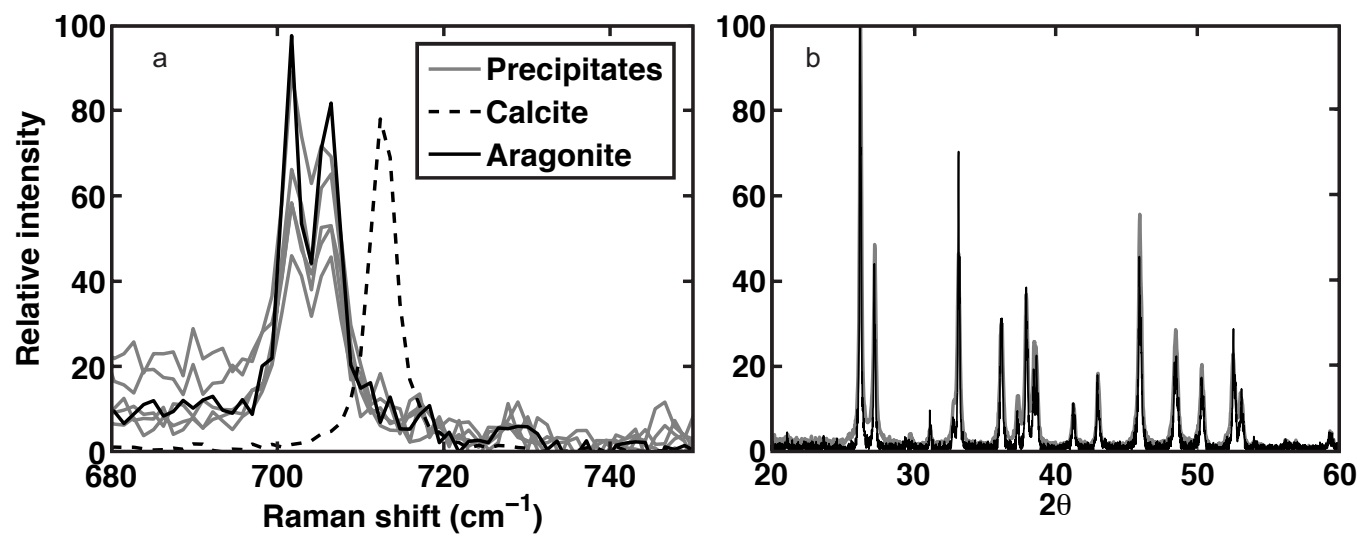

Figure 2-3: Raman and XRD analysis of experimental precipitates. (a) Raman spectra focused on the peaks around $700 \mathrm{~cm}^{-1}$ of aragonite (solid black) and calcite (dashed black) grains, and five example spectra (gray) collected from different experimental precipitates. (b) XRD pattern for aragonite (black) from RRUFF database (ID R060195.1) and a pattern collected on a subset of the precipitate formed in experiment h10 (gray). Raman and XRD data collected on each experimental precipitate clearly indicate the presence of aragonite with no other contaminating phases.

consistent with the other experiments (SEM images in supplementary), and elemental ratios are consistent with the other experiments (i.e. this experiment is not an outlier in $K_{D}^{S r / C a}$ or $K_{D}^{U / C O 3}$ ), this experiment is likely free of significant contamination.

Mean differences between duplicate subsamples of a given precipitate were 0.59 $\%$ and $1.15 \%$ for measured $\mathrm{Sr} / \mathrm{Ca}$ and $\mathrm{U} / \mathrm{Ca}$, respectively. The relative differences between duplicates were less than $2 \sigma$ instrument precision for both $\mathrm{Sr} / \mathrm{Ca}$ and U/Ca. Although composition may vary within individual crystals (i.e. the composition is zoned), for the purposes of this study where we calculate partitioning relative to the bulk aragonite and fluid compositions, sample heterogeneity was not considered a source of error in the Monte Carlo simulation.

\subsubsection{Temperature dependence of element partitioning}

Results from our experiments demonstrate that $K_{D}^{S r / C a}$ is significantly $(\mathrm{p}<0.05)$ inversely correlated with $T$ (Fig. 2-4), whereas $K_{D}^{U / C O 3}$ is independent of $T$ (p > 0.05 ) at 20 to $40{ }^{\circ} \mathrm{C}$ after accounting for the effect of $\left[\mathrm{CO}_{3}^{2-}\right]$ as described below in section 3.3 (i.e. in multiple regression where the influences of $T$ and $\left[\mathrm{CO}_{3}^{2-}\right]$ on $K_{D}^{U / C O 3}$ are evaluated together, there is no significant effect of $T$ ). Ordinary least- 
Table 2.2: Summary of conditions and calculated $K_{D}^{S r / C a}$ and $K_{D}^{U / C O 3}$ for each experiment.

\begin{tabular}{|c|c|c|c|c|c|c|c|c|c|}
\hline Experiment & $\begin{array}{l}\mathrm{T} \\
{ }^{\circ} \mathrm{C}\end{array}$ & $\begin{array}{l}\text { Final } \\
\text { salinity }\end{array}$ & $\begin{array}{l}\text { Precipitation rate } \\
\left(\mu \mathrm{mol} \mathrm{m} \mathrm{m}^{-2} \mathrm{hr}^{-1}\right)\end{array}$ & $\begin{array}{l}\text { TA } \\
\left(\mu \text { eq } \mathrm{kg}^{-1}\right)\end{array}$ & $\mathrm{pH}_{T}$ & $\begin{array}{l}{\left[\mathrm{CO}_{3}^{2-}\right]} \\
(\mu \mathrm{mol} \mathrm{kg}-1)\end{array}$ & $\Omega_{\text {Arag }}$ & $K_{D}^{S r / C a}$ & $K_{D}^{U / C O 3}$ \\
\hline h02 & 20 & 32.455 & $3.4(0.6) \times 10^{3}$ & $7(0.2) \times 10^{3}$ & $8.88(0.01)$ & $2.06(0.09) \times 10^{3}$ & $29(4)$ & $1.13(0.01)$ & $0.33(0.01)$ \\
\hline h08 & 20 & 32.75 & $2.2(0.6) \times 10^{3}$ & $13.1(0.9) \times 10^{3}$ & $8.20(0.01)$ & $1.60(0.09) \times 10^{3}$ & $21(4)$ & $1.17(0.01)$ & $0.36(0.02)$ \\
\hline f01 & 25.5 & 32.703 & $4(2) \times 10^{3}$ & $5.8(0.2) \times 10^{3}$ & $8.62(0.02)$ & $1.31(0.07) \times 10^{3}$ & $16(4)$ & $1.13(0.02)$ & $0.33(0.01)$ \\
\hline f02 & 25.5 & 32.523 & $6(2) \times 10^{3}$ & $7.4(0.3) \times 10^{3}$ & $8.48(0.02)$ & $1.4(0.1) \times 10^{3}$ & $19(3)$ & $1.14(0.01)$ & $0.32(0.01)$ \\
\hline f03 & 25.5 & 32.342 & $13(3) \times 10^{3}$ & $6.8(0.2) \times 10^{3}$ & $8.96(0.02)$ & $2.1(0.1) \times 10^{3}$ & $30(4)$ & $1.08(0.01)$ & $0.363(0.009)$ \\
\hline f04 & 25.5 & 32.686 & $5(2) \times 10^{3}$ & $11.9(0.7) \times 10^{3}$ & $8.16(0.01)$ & $1.38(0.07) \times 10^{3}$ & $19(3)$ & $1.10(0.02)$ & $0.32(0.01)$ \\
\hline f05 & 25.5 & 32.493 & $16(3) \times 10^{3}$ & $7.8(0.2) \times 10^{3}$ & $9.03(0.01)$ & $2.56(0.08) \times 10^{3}$ & $34(3)$ & $1.06(0.01)$ & $0.351(0.009)$ \\
\hline f06 & 25.5 & 32.764 & $2.1(0.5) \times 10^{3}$ & $5.3(0.3) \times 10^{3}$ & $8.38(0.01)$ & $0.86(0.06) \times 10^{3}$ & $11(1)$ & $1.13(0.01)$ & $0.25(0.01)$ \\
\hline f08 & 25.5 & 32.047 & $2(2) \times 10^{3}$ & $8(1) \times 10^{3}$ & $7.90(0.07)$ & $0.6(0.2) \times 10^{3}$ & $12(4)$ & $1.16(0.01)$ & $0.174(0.009)$ \\
\hline g01 & 25.5 & 32.269 & $7(2) \times 10^{3}$ & $5.8(0.3) \times 10^{3}$ & $8.80(0.02)$ & $1.6(0.1) \times 10^{3}$ & $21(4)$ & $1.13(0.01)$ & $0.34(0.01)$ \\
\hline g03 & 25.5 & 32.438 & $5(1) \times 10^{3}$ & $7.0(0.3) \times 10^{3}$ & $8.43(0.01)$ & $1.23(0.08) \times 10^{3}$ & $17(3)$ & $1.13(0.01)$ & $0.30(0.01)$ \\
\hline g04 & 25.5 & 32.514 & $9(2) \times 10^{3}$ & $9.1(0.3) \times 10^{3}$ & $8.48(0.01)$ & $1.72(0.06) \times 10^{3}$ & $25(3)$ & $1.11(0.02)$ & $0.36(0.01)$ \\
\hline g05 & 25.5 & 32.68 & $5(1) \times 10^{3}$ & $14.7(0.8) \times 10^{3}$ & $8.02(0.02)$ & $1.32(0.07) \times 10^{3}$ & $18(2)$ & $1.12(0.03)$ & $0.31(0.01)$ \\
\hline g06 & 25.5 & 32.541 & $5(2) \times 10^{3}$ & $10.4(0.6) \times 10^{3}$ & $8.24(0.02)$ & $1.36(0.06) \times 10^{3}$ & $18(3)$ & $1.15(0.02)$ & $0.29(0.01)$ \\
\hline g07 & 25.5 & 32.901 & $8(2) \times 10^{3}$ & $20(2) \times 10^{3}$ & $8.00(0.01)$ & $1.7(0.2) \times 10^{3}$ & $24(3)$ & $1.13(0.01)$ & $0.32(0.01)$ \\
\hline g08 & 25.5 & 32.47 & $10(3) \times 10^{3}$ & $10.0(0.6) \times 10^{3}$ & $8.49(0.02)$ & $1.9(0.1) \times 10^{3}$ & $26(4)$ & $1.09(0.02)$ & $0.35(0.01)$ \\
\hline g09 & 25.5 & 33.4 & $8(3) \times 10^{3}$ & $30(3) \times 10^{3}$ & $7.78(0.02)$ & $1.7(0.2) \times 10^{3}$ & $23(5)$ & $1.12(0.02)$ & $0.38(0.02)$ \\
\hline g10 & 25.5 & 32.772 & $5(2) \times 10^{3}$ & $15(2) \times 10^{3}$ & $8.06(0.04)$ & $1.5(0.1) \times 10^{3}$ & $18(3)$ & $1.03(0.04)$ & $0.29(0.01)$ \\
\hline g11 & 25.5 & 33.158 & $4(1) \times 10^{3}$ & $22.9(0.9) \times 10^{3}$ & $7.79(0.02)$ & $1.29(0.07) \times 10^{3}$ & $17(2)$ & $1.13(0.01)$ & $0.31(0.01)$ \\
\hline g13 & 25.5 & 32.25 & $1.7(0.9) \times 10^{3}$ & $8(1) \times 10^{3}$ & $7.89(0.02)$ & $0.6(0.1) \times 10^{3}$ & $10(3)$ & $1.07(0.02)$ & $0.154(0.008)$ \\
\hline h01 & 25.5 & 32.486 & $7(2) \times 10^{3}$ & $5.9(0.2) \times 10^{3}$ & $8.86(0.01)$ & $1.69(0.08) \times 10^{3}$ & $21(4)$ & $1.14(0.01)$ & $0.34(0.01)$ \\
\hline h09 & 25.5 & 33.041 & $3(1) \times 10^{3}$ & $16(1) \times 10^{3}$ & $7.89(0.03)$ & $1.1(0.1) \times 10^{3}$ & $14(3)$ & $1.09(0.02)$ & $0.26(0.01)$ \\
\hline h10 & 25.5 & 33.297 & $7(3) \times 10^{3}$ & $30(2) \times 10^{3}$ & $7.78(0.03)$ & $1.6(0.1) \times 10^{3}$ & $21(4)$ & $1.10(0.03)$ & $0.35(0.02)$ \\
\hline h03 & 33 & 32.471 & $18(8) \times 10^{3}$ & $5.2(0.2) \times 10^{3}$ & $8.69(0.03)$ & $1.3(0.1) \times 10^{3}$ & $17(3)$ & $1.07(0.01)$ & $0.34(0.01)$ \\
\hline h07 & 33 & 32.501 & $13(3) \times 10^{3}$ & $9.9(0.5) \times 10^{3}$ & $8.13(0.03)$ & $1.07(0.07) \times 10^{3}$ & $15(1)$ & $1.10(0.01)$ & $0.29(0.01)$ \\
\hline h05 & 40 & 32.532 & $40(20) \times 10^{3}$ & $4.7(0.1) \times 10^{3}$ & $8.67(0.01)$ & $1.10(0.04) \times 10^{3}$ & $15(2)$ & $1.05(0.01)$ & $0.31(0.01)$ \\
\hline h06 & 40 & 32.572 & $22(9) \times 10^{3}$ & $8.0(0.4) \times 10^{3}$ & $8.12(0.04)$ & $0.85(0.06) \times 10^{3}$ & $12(2)$ & $1.04(0.02)$ & $0.24(0.01)$ \\
\hline
\end{tabular}

Notes: Numbers in parentheses indicate $\pm 1 \sigma$. T, salinity, TA, and $\mathrm{pH}_{T}$ are measured, while $\mathrm{CO}_{3}^{2-}$, and $\Omega_{\text {Arag }}$ are calculated with CO2SYS. $\mathrm{pH}$ reported on the total scale, calculated as $\mathrm{pH}_{N B S}-0.099$. Precipitation rate is calculated based upon results of Burton and Walter (1987) where uncertainty is reported as $\pm 1 \sigma$ by propagating uncertainty from the estimate of mean $\Omega_{\text {Arag }}$.

squares linear regression of mean at each $T$ resulted in the following $T$ dependence (numbers in parentheses indicate one standard error uncertainties):

$$
K_{D}^{S r / C a}=-0.0047(0.0003) T+1.24(0.01)\left(r^{2}=0.99\right)
$$

where $T$ is in ${ }^{\circ} \mathrm{C}$. The $T$ dependence of $K_{D}^{S r / C a}$ determined between 20 and $40{ }^{\circ} \mathrm{C}$ is within uncertainty of that determined in three previous experimental studies employing different methodologies (Kinsman and Holland, 1969; Dietzel et al., 2004; Gaetani and Cohen, 2006). This clearly shows that the lack of $T$ dependence for $K_{D}^{U / C O 3}$ is not an artifact of our experimental design or sampling resolution masking the influence of $T$ on element partitioning. Nevertheless, the $K_{D}^{S r / C a}$ variability at $25.5^{\circ} \mathrm{C}$ $( \pm 0.031 \sigma)$ is approximately twice as large as expected on the basis of the analyti- 
Table 2.3: Coefficient of determination $\left(\mathrm{r}^{2}\right)$ matrix for carbonate system parameters across all experiments $(\mathrm{n}=27)$.

\begin{tabular}{llllll}
\hline & $\mathrm{TA}$ & $\mathrm{pH}_{T}$ & $\mathrm{HCO}_{3}^{-}$ & $\mathrm{CO}_{3}^{2-}$ & $\Omega_{\text {Arag }}$ \\
\hline $\mathrm{DIC}$ & 0.995 & 0.581 & 0.996 & 0.004 & 0.000 \\
$\mathrm{TA}$ & & 0.513 & 0.981 & 0.019 & 0.007 \\
$\mathrm{pHT}$ & & & 0.638 & 0.278 & 0.283 \\
$\mathrm{HCO}_{3}^{-}$ & & & & 0.000 & 0.002 \\
$\mathrm{CO}_{3}^{2-}$ & & & & & 0.954 \\
\hline
\end{tabular}

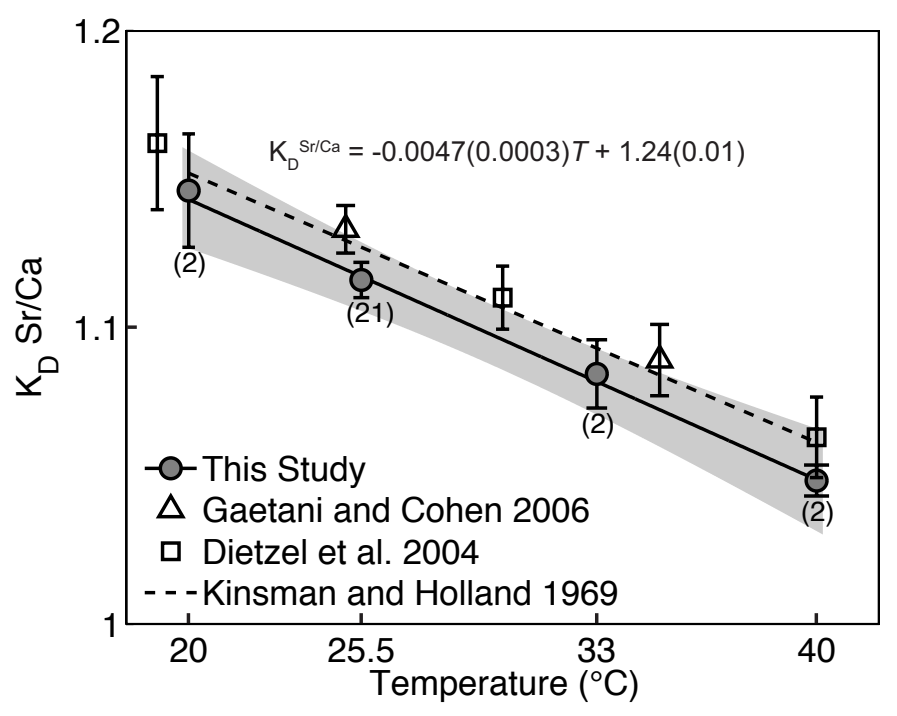

Figure 2-4: Temperature dependence of $K_{D}^{S r / C a}$. Solid line is regression performed with mean $K_{D}^{S r / C a}$ at each temperature, and shading is $95 \%$ confidence interval. Error bars from this study are standard errors of mean $K_{D}^{S r / C a}$, and numbers in parentheses indicate the number of experiments, at each temperature. Note that \pm standard error of two samples is equivalent to the range. Error bars on data from Gaetani and Cohen (2006) and Dietzel et al. (2004) are analytical error and standard deviation of replicates measurements, respectively. 
Figure 2-5: Dependence of $K_{D}^{U / C O 3}$ on $\left[\mathrm{CO}_{3}^{2-}\right]$ of the fluid. Solid line is logarithmic regression performed with all 27 experiments, and shading is $95 \%$ confidence interval. Error bars show $1 \sigma$ uncertainties. Note that $\left[\mathrm{CO}_{3}^{2-}\right]$ is plotted on a logarithmic scale.

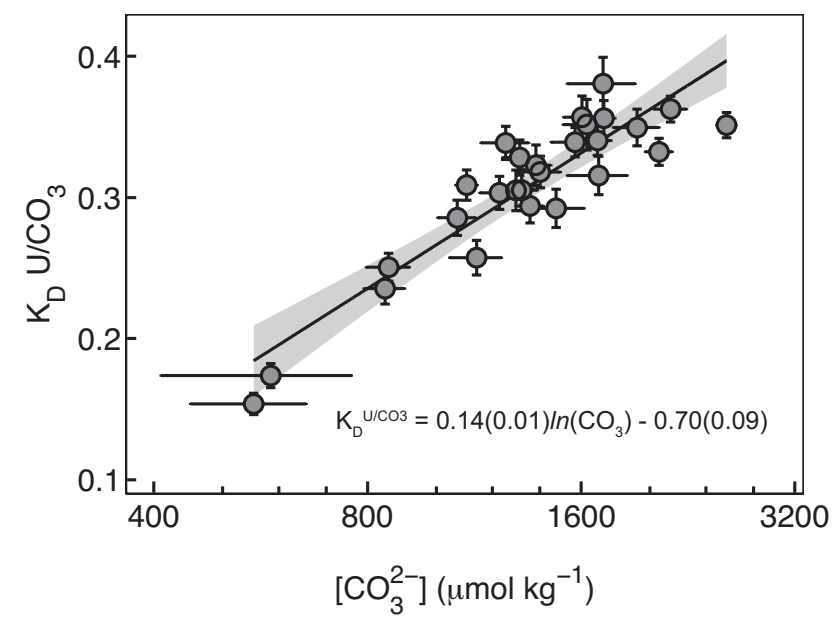

cal uncertainties of individual experiments (Table 2.2), and this variability does not correlate with any of the measured parameters. Similar variability was reported by Dietzel et al. (2004) and Kinsman and Holland (1969) ( \pm 0.02 and $\pm 0.051 \sigma$ respectively, determined from replicate experiments). Despite this, the $T$ dependence of $K_{D}^{S r / C a}$ derived from averaging all experiments conducted at each $T$ appears robust, indicating that $K_{D}^{S r / C a}$ likely follows a Gaussian distribution at a given $T\left(K_{D}^{S r / C a}\right.$ from experiments conducted at $25.5{ }^{\circ} \mathrm{C}$ is not significantly different from a normal distribution, Kolmogorov-Smirnov test, $\mathrm{p}>0.05)$. Our results also contrast the $T$ dependence of $\mathrm{Sr} / \mathrm{Ca}$ in abiogenic experiments (-0.039 to $0.044 \mathrm{mmol} \mathrm{mol}^{-1} \mathrm{Sr} / \mathrm{Ca}$ per ${ }^{\circ} \mathrm{C}$ ) with that of coral (typically -0.05 to $-0.1 \mathrm{mmol} \mathrm{mol}^{-1} \mathrm{Sr} / \mathrm{Ca}$ per ${ }^{\circ} \mathrm{C}$ ), which reinforces previous conclusions that factors other than $T$, such as Rayleigh fractionation (Gaetani and Cohen, 2006), are driving a significant component of the $\mathrm{Sr} / \mathrm{Ca}$ variability in corals.

\subsubsection{Carbonate chemistry dependence of element partition- ing}

The influence of carbonate chemistry on $K_{D}^{S r / C a}$ was investigated using only the experiments conducted at $25.5{ }^{\circ} \mathrm{C}$, whereas all experiments were used to evaluate the carbonate chemistry dependence of $K_{D}^{U / C O 3}$ because of the lack of any discernible $T$ effect. Mean solution $\mathrm{pH}$ and $\left[\mathrm{CO}_{3}^{2-}\right]$ are only weakly correlated $\left(\mathrm{r}^{2}=0.28\right)$, whereas 
there are negligible correlations between $\left[\mathrm{CO}_{3}^{2-}\right]$ and both $\left[\mathrm{HCO}_{3}^{-}\right]$and $\mathrm{TA}\left(\mathrm{r}^{2}<0.1\right)$, allowing the influence of these variables on partitioning to be resolved from one another (Table 2.3). However, a strong correlation between $\left[\mathrm{CO}_{3}^{2-}\right]$ and $\Omega_{\text {Arag }}\left(\mathrm{r}^{2}=\right.$ 0.95) precludes resolving the influence of these two variables. In seawater, variation in $\Omega_{\text {Arag }}$ is dominated by variability in $\left[\mathrm{CO}_{3}^{2-}\right]$ because of its dependence on biogeochemical processes, whereas $\left[\mathrm{Ca}^{2+}\right]$ varies by only a few percent in accordance with changes in salinity. Corals change the $\left[\mathrm{Ca}^{2+}\right]$ of their calcifying fluid by less than $10 \%$ from the seawater concentration but elevate $\mathrm{pH}$ to greater than 9 (Al-Horani et al., 2003), implying that $\left[\mathrm{CO}_{3}^{2-}\right]$ potentially increases to several times that of seawater. Thus, while future experiments could provide valuable insights regarding the relative importance of $\left[\mathrm{CO}_{3}^{2-}\right]$ and $\Omega_{\text {Arag }}$ on element partitioning, in the context of aragonite precipitated from seawater, or the modified seawater of the coral calcifying fluid, these variables are not independent from one another. There are no significant correlations between and carbonate system parameters $\left(\mathrm{pH} ;\left[\mathrm{CO}_{3}^{2-}\right] ; \Omega_{\text {Arag }}\right.$; $\left[\mathrm{HCO}_{3}^{-}\right]$; TA; dissolved inorganic carbon (DIC)) or precipitation rate, whereas $K_{D}^{U / C O 3}$ is significantly positively correlated with $\left[\mathrm{CO}_{3}^{2-}\right](\mathrm{p}<0.05)$, accounting for $83 \%$ of the total variance (Fig. 2-5). There is also a significant correlation between and $\mathrm{pH}$, but only $19 \%$ of variance in $K_{D}^{U / C O 3}$ can be accounted for in this way. Further, the residuals of $K_{D}^{U / C O 3}$ regressed against $\left[\mathrm{CO}_{3}^{2-}\right]$ are not significantly correlated with $\mathrm{pH}$ (i.e. multiple regression yields a significant $\left[\mathrm{CO}_{3}^{2-}\right]$ effect but no significant $\mathrm{pH}$ effect). Thus, $\left[\mathrm{CO}_{3}^{2-}\right]$ is the variable influencing $K_{D}^{U / C O 3}$, while the apparent $\mathrm{pH}$ effect is an artifact of the weak correlation between $\mathrm{pH}$ and $\left[\mathrm{CO}_{3}^{2-}\right]$ in our experiments. The dependence of $K_{D}^{U / C O 3}$ on $\left[\mathrm{CO}_{3}^{2-}\right]$ was fit by logarithmic regression because the residual $K_{D}^{U / C O 3}$ did not correlate with either $K_{D}^{U / C O 3}$ or $\left[\mathrm{CO}_{3}^{2-}\right]$ :

$$
K_{D}^{U / C O 3}=0.14(0.01) \ln \left(\left[C O_{3}^{2-}\right]\right)-0.70(0.09)\left(r^{2}=0.83\right)
$$

where $\left[\mathrm{CO}_{3}^{2-}\right]$ is in $\mu \mathrm{mol} \mathrm{kg}{ }^{-1}$. The activity ratio $\left\{\mathrm{UO}_{2}\left(\mathrm{CO}_{3}\right)_{3}^{4-}\right\} /\left\{\mathrm{CO}_{3}^{2-}\right\}$ is strongly correlated with the concentration ratio $\left[\mathrm{UO}_{2}\left(\mathrm{CO}_{3}\right)_{3}^{4-}\right] /\left[\mathrm{CO}_{3}^{2-}\right]$ in our experiments $\left(\mathrm{r}^{2}\right.$ $=0.978)$, meaning that the general relationship between $K_{D}^{U / C O 3}$ and $\left[\mathrm{CO}_{3}^{2-}\right]$ would 
not change if we defined $K_{D}^{U / C O 3}$ with activity ratios instead of concentration ratios.

\subsection{Discussion}

\subsubsection{Partitioning of $U$ between abiogenic aragonite and sea- water}

Our experimental results indicate that $\left[\mathrm{CO}_{3}^{2-}\right]$ has a significant influence on the partitioning of $\mathrm{U}$ between abiogenic aragonite and seawater. As $\left[\mathrm{CO}_{3}^{2-}\right]$ increases from $600 \pm 100$ to $2560 \pm 80 \mu \mathrm{mol} \mathrm{kg}{ }^{-1}$ in the experimental seawater, $K_{D}^{U / C O 3}$ increases from $0.154 \pm 0.008$ to $0.351 \pm 0.009$. Conversely, our results do not indicate a direct link between $\left[\mathrm{CO}_{3}^{2-}\right]$ and either $T$ or $\mathrm{pH}$. Here we discuss two potential mechanisms for explaining the dependence of $K_{D}^{U / C O 3}$ on $\left[\mathrm{CO}_{3}^{2-}\right]$ : the kinetics of aragonite growth and the speciation of $\mathrm{UO}_{2}^{2+}$ in seawater. We then show how our experimental results bear on interpretation of $\mathrm{U} / \mathrm{Ca}$ in aragonite.

The kinetics of aragonite growth provides one possible explanation for the influence of $\left[\mathrm{CO}_{3}^{2-}\right]$ on the partitioning of $\mathrm{U}$ between aragonite and seawater. Gaetani and Cohen (2006) showed that the partitioning of $\mathrm{Mg}, \mathrm{Sr}$ and $\mathrm{Ba}$ is consistent with the surface entrapment mechanism proposed by Watson (2004). At equilibrium, these elements are enriched in the near-surface region of an aragonite crystal relative to the lattice (Watson, 2004). As the near-surface region of the crystal is incorporated into the lattice, its composition must be modified in order to maintain equilibrium. In a slow-growing crystal, the elemental composition approaches equilibrium as enriched impurities are removed from the lattice via cation transport in the near surface region of the crystal. As crystal growth rate increases, the concentration of impurities "buried" as the near-surface region of the growing crystal advances increases, resulting in a larger apparent $\mathrm{K}_{D}$. As noted above, $\Omega_{\text {Arag }}$ is positively correlated with $\left[\mathrm{CO}_{3}^{2-}\right]$ in our experiments. Given the well established relationship between $\Omega_{\text {Arag }}$ and precipitation rate (Table 2) (Burton and Walter, 1987), the potential exists for a positive correlation between $\left[\mathrm{CO}_{3}^{2-}\right]$ and crystal growth rate and, thereby, increas- 

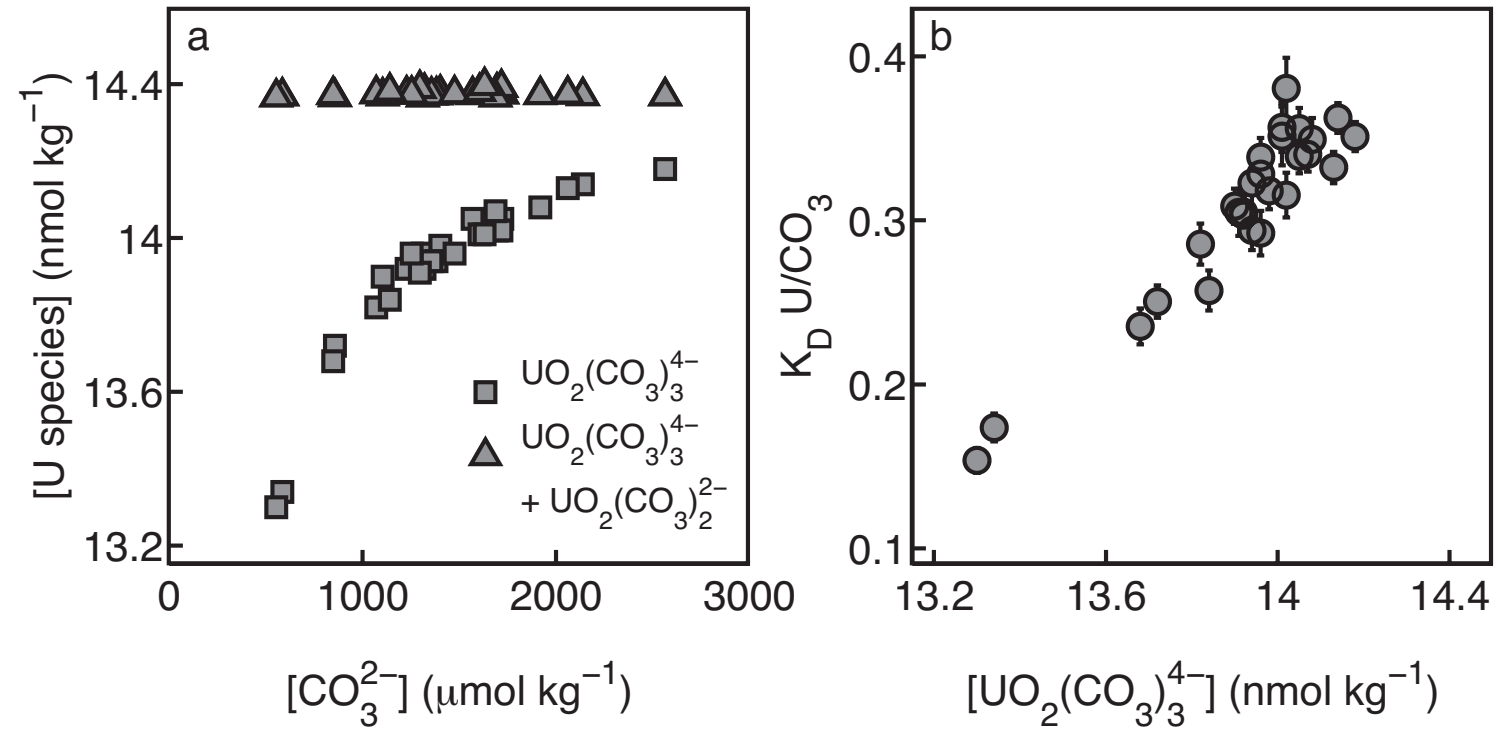

Figure 2-6: The influence of $\mathbf{U O}_{2}^{2+}$ speciation in seawater on $K_{D}^{U / C O 3}$. (a) $\left[\mathbf{C O}_{3}^{2-}\right]$ dependence of the concentration of $\mathrm{UO}_{2}\left(\mathrm{CO}_{3}\right)_{2}^{2-}$ and $\mathrm{UO}_{2}\left(\mathrm{CO}_{3}\right)_{3}^{4-}$ in seawater with $\mathbf{1 3 . 9}$ nmol $\mathrm{kg}^{-1} \mathrm{U}$, calculated with the program PHREEQC using the measured $\mathrm{pH}_{T}$ and TA conditions of each experiment. [ $\mathrm{UO}_{2}\left(\mathrm{CO}_{3}\right)_{3}^{4-}$ ] (squares) increases with increasing $\left[\mathrm{CO}_{3}^{2-}\right]$, while the sum $\left[\mathrm{UO}_{2}\left(\mathbf{C O}_{3}\right)_{2}^{2-}+\mathbf{U O}_{2}\left(\mathbf{C O}_{3}\right)_{3}^{4-}\right]$ (triangles) remains approximately constant, indicating that the dominant change in speciation across our experiments is a conversion of $\mathrm{UO}_{2}\left(\mathrm{CO}_{3}\right)_{2}^{2-}$ to $\mathrm{UO}_{2}\left(\mathrm{CO}_{3}\right)_{3}^{4-}$ with increasing $\left[\mathrm{CO}_{3}^{2-}\right]$. Concentration of all other $\mathrm{UO}_{2}^{2+}$ species calculated as less than $0.003 \mathrm{nmol} \mathrm{kg-1.} \mathrm{(b)} \mathrm{Correlation} \mathrm{between}$ measured $K_{D}^{U / C O 3}$ and calculated concentration of $\mathbf{U O}_{2}\left(\mathbf{C O}_{3}\right)_{3}^{4-}$ for each experiment.

ing surface entrapment. This mechanism could explain the increase in $K_{D}^{U / C O 3}$ with increasing $\left[\mathrm{CO}_{3}^{2-}\right]$, and is consistent with the finding of Gabitov et al. (2008) that $K_{D}^{U / C a}$ increases with increasing precipitation rate until reaching a plateau at high precipitate rate. However, given that cation transport is $T$ dependent (Gaetani and Cohen, 2006), a surface entrapment mechanism implies that $K_{D}^{U / C O 3}$ should be sensitive to both $\left[\mathrm{CO}_{3}^{2-}\right]$ and $T$. Gabitov et al. (2008) found that $K_{D}^{U / C a}$ increased from 22 ${ }^{\circ} \mathrm{C}$ to $53{ }^{\circ} \mathrm{C}$, but this is potentially an artifact because those experiments did not isolate $\left[\mathrm{CO}_{3}^{2-}\right]$ from $T$. Further, since aragonite was precipitated from aqueous chloride solutions with [U] much higher than that of seawater in the experiments of Gabitov et al. (2008), U partitioning in that study may be influenced by different factors than our study, in which aragonite was precipitated from modified seawater. That 
our experimental results do not indicate any significant $T$ dependence for $K_{D}^{U / C O 3}$ at 20 to $40{ }^{\circ} \mathrm{C}$ makes a surface entrapment mechanism an unlikely explanation for our observations.

A second potential mechanism by which the partitioning of $\mathrm{U}$ between aragonite and seawater could be sensitive to $\left[\mathrm{CO}_{3}^{2-}\right]$ derives from the tendency of $\mathrm{UO}_{2}^{2+}$ to form various complexes with $\mathrm{CO}_{3}^{2-}$ in seawater $\left(\mathrm{UO}_{2}\left(\mathrm{CO}_{3}\right) ; \mathrm{UO}_{2}\left(\mathrm{CO}_{3}\right)_{2}^{2-} ; \mathrm{UO}_{2}\left(\mathrm{CO}_{3}\right)_{3}^{4-}\right)$ as a function of $\mathrm{pH}$ (Djogic et al., 1986) and/or $\left[\mathrm{CO}_{3}^{2-}\right]$ (Kitano and Oomori, 1971; Saito and Miyauchi, 1982). The incorporation of $\mathrm{CO}_{3}^{2-}$ into aragonite involves exchange of $\mathrm{UO}_{2}\left(\mathrm{CO}_{3}\right)_{3}^{4-}$ - the dominant complex in seawater with $\mathrm{pH} 8$ (Djogic et al., 1986) - for $\mathrm{CO}_{3}^{2-}$ in the aragonite lattice (Reeder et al., 2000). This combination of factors suggests that the incorporation of $\mathrm{CO}_{3}^{2-}$ into aragonite could be sensitive to $\mathrm{pH}$ and/or $\left[\mathrm{CO}_{3}^{2-}\right]$ because the relative abundance of different uranyl-carbonate complexes varies with carbonate chemistry. A preliminary test of this hypothesis was performed by conducting speciation calculations using the PHREEQC database and software package (Parkhurst and Appelo, 1999) to predict the relative abundances of complexes in our experimental fluids. The modeled abundance of $\mathrm{UO}_{2}\left(\mathrm{CO}_{3}\right)_{3}^{4-}$ ( $\mathrm{UO}_{2}^{2+}+3 \mathrm{CO}_{3}^{2-}=\mathrm{UO}_{2}\left(\mathrm{CO}_{3}\right)_{3}^{4-} ; \log _{10} K=21.397$ at $\left.25.5^{\circ} \mathrm{C}\right)$ increases with increasing $\left[\mathrm{CO}_{3}^{2-}\right]$ in a manner that is consistent with our experimental results $\left(\mathrm{r}^{2}=0.89\right.$ between $\left[\mathrm{UO}_{2}\left(\mathrm{CO}_{3}\right)_{3}^{4-}\right]$ and $\left.K_{D}^{U / C O 3}\right)$, although the magnitude of change predicted by the PHREEQC model is significantly less than that observed in our experiments (Fig. 2-6). However, without direct measurements of the speciation of $\mathrm{UO}_{2}^{2+}$ in the experimental solutions, this mechanism cannot be ruled out and remains the most plausible explanation for our data.

The relationship between $K_{D}^{U / C O 3}$ and $\left[\mathrm{CO}_{3}^{2-}\right]$ determined from our experimental results can be used to predict the sensitivity of aragonite $\mathrm{U} / \mathrm{Ca}$ to seawater $\left[\mathrm{CO}_{3}^{2-}\right]$. As discussed above, the exchange coefficient $K_{D}^{U / C O 3}$ increases with increasing $\left[\mathrm{CO}_{3}^{2-}\right]$, which serves to raise the $\mathrm{U} / \mathrm{CO}_{3}^{2-}$ ratio of aragonite with respect to that of seawater. While $\mathrm{U}$ is effectively conservative in seawater, changing only in proportion to salinity (e.g., Owens et al., 2011; but see Mann and Wong (1993) for exceptions in coastal waters), $\mathrm{CO}_{3}^{2-}$ is non-conservative and varies in response to changes in TA and/or 


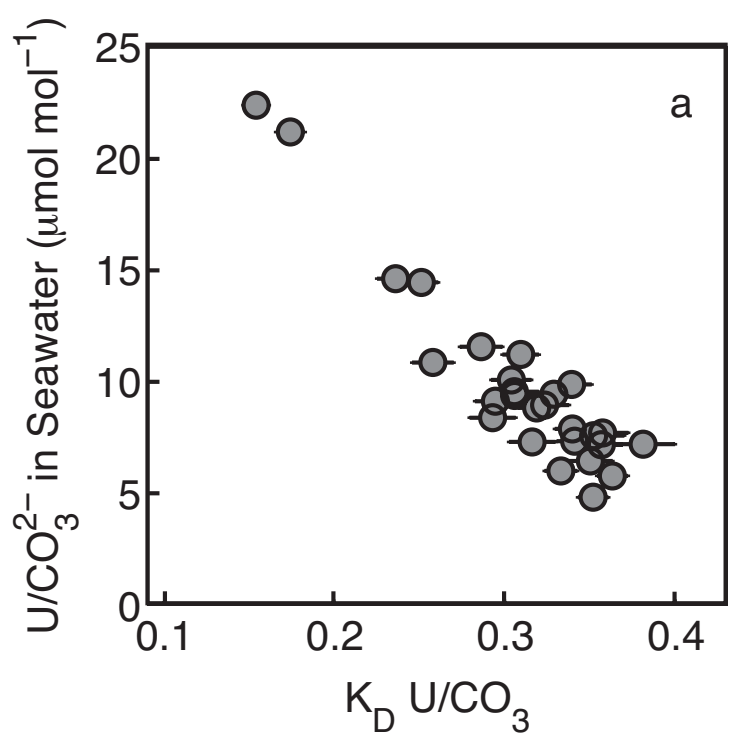

$\mathrm{U} / \mathrm{CO}_{3}^{2-}$ in Seawater $\left(\mu \mathrm{mol} \mathrm{mol}{ }^{-1}\right)$

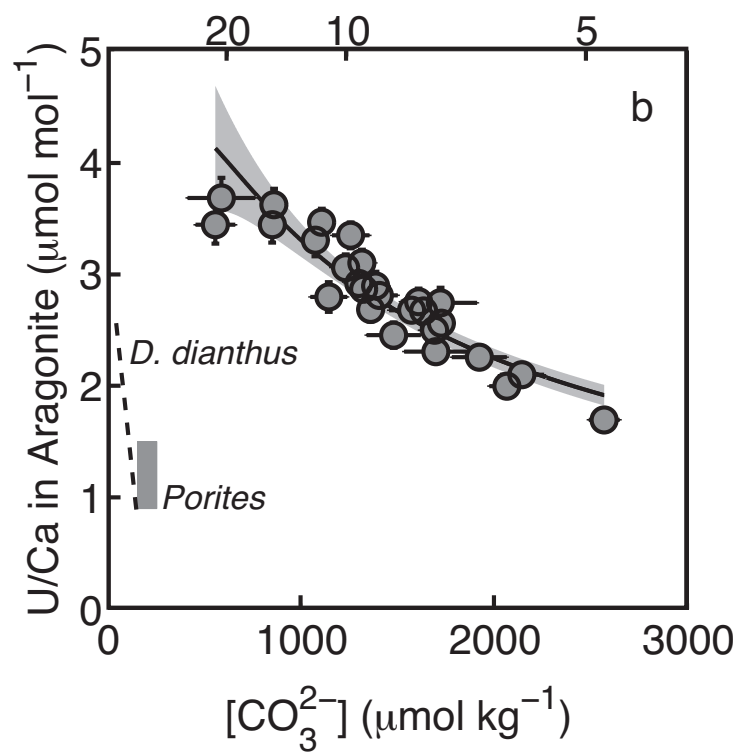

Figure 2-7: Dependence of aragonite U/Ca on seawater $\left[\mathrm{CO}_{3}^{2-}\right]$. (a) Correlation between the $\mathrm{U} / \mathrm{CO}_{3}^{2-}$ ratio of seawater and the experimentally determined $K_{D}^{U / C O 3}$, where the $\mathrm{U} / \mathrm{CO}_{3}^{2-}$ ratio is calculated from $[\mathrm{U}]$ in seawater of salinity 35 ([U] $=14.7 \mathrm{nmol}$ $\left.\mathrm{kg}^{-1}\right)$ and the $\left[\mathrm{CO}_{3}^{2-}\right]$ of each experiment. (b) Predicted $\left[\mathrm{CO}_{3}^{2-}\right]$ dependence of the $\mathrm{U} / \mathrm{Ca}$ ratio of aragonite precipitating from an infinite reservoir of seawater (solid line), calculated as the product of $K_{D}^{U / C O 3}$ from Eq. (10) and the seawater $\mathrm{U} / \mathrm{CO}_{3}^{2-}$ ratio (shading is $95 \%$ confidence interval). The top abscissa shows how the $\mathrm{U} / \mathrm{CO}_{3}^{2-}$ ratio changes with $\left[\mathrm{CO}_{3}^{2-}\right]$ in seawater of salinity 35 . Circles indicate the predicted aragonite $\mathrm{U} / \mathrm{Ca}$ ratio from $K_{D}^{U / C O 3}$ and $\left[\mathrm{CO}_{3}^{2-}\right]$ of each experiment. The dashed line shows the observed relationship between seawater $\left[\mathrm{CO}_{3}^{2-}\right]$ and $\mathrm{U} / \mathrm{Ca}$ in the deep-sea coral $\mathrm{D}$. dianthus (Anagnostou et al., 2011). The gray box indicates the approximate ranges of U/Ca ratios of shallow-water Porites skeletons $\left(\sim 0.9-1.5 \mu \mathrm{mol} \mathrm{mol}{ }^{-1}\right)$ and the of the seawater in which these corals live $\left(150-250 \mu \mathrm{mol} \mathrm{kg} \mathbf{k g}^{-1}\right)$. Error bars show $1 \sigma$ uncertainties.

DIC. Therefore, increasing $\left[\mathrm{CO}_{3}^{2-}\right]$ at constant salinity decreases the $\mathrm{U} / \mathrm{CO}_{3}^{2-}$ ratio of seawater, resulting in a negative correlation between $\mathrm{U} / \mathrm{CO}_{3}^{2-}$ and $K_{D}^{U / C O 3}$ (Fig. 2-7a). The $\mathrm{U} / \mathrm{Ca}$ ratio of aragonite can be calculated from $K_{D}^{U / C O 3}$ because it is approximately equal to the $\mathrm{U} / \mathrm{CO}_{3}^{2-}$ ratio (i.e. $\mathrm{Ca}^{2+}$ and are stoichiometrically linked by charge balance in the crystals). This allows the $\mathrm{U} / \mathrm{Ca}$ ratio of aragonite to be calculated as a function of $\left[\mathrm{CO}_{3}^{2-}\right]$. Results from this calculation show that although $K_{D}^{U / C O 3}$ increases with $\left[\mathrm{CO}_{3}^{2-}\right]$ (Fig. 2-5), the U/Ca ratio of abiogenic aragonite precipitated from an infinite reservoir of seawater decreases with increasing $\left[\mathrm{CO}_{3}^{2-}\right]$ 
(Fig. 2-7b). The reason for this negative dependence of $\mathrm{U} / \mathrm{Ca}$ on fluid $\left[\mathrm{CO}_{3}^{2-}\right]$ is that $\mathrm{U} / \mathrm{Ca}$ is directly proportional to $K_{D}^{U / C O 3}$, and directly inversely proportional to fluid $\mathrm{U} / \mathrm{CO}_{3}^{2-}$, but the percent difference between maximum and minimum $K_{D}^{U / C O 3}(59 \%)$ is less than that of fluid $\mathrm{U} / \mathrm{CO}_{3}^{2-}(77 \%)$.

In their abiogenic precipitation experiments, Meece and Benninger (1993) expressed U partitioning between aragonite and seawater as $K_{D}^{U / C a}$, rather than $K_{D}^{U / C O 3}$, and found that the $\mathrm{U} / \mathrm{Ca}$ ratio of aragonite decreases with increasing $\mathrm{pH}$. Likewise, Kitano and Oomori (1971) precipitated aragonite from magnesium chloride and sodium chloride solutions and found that $K_{D}^{U / C a}$ decreases as $\mathrm{pH}$ increases. The results of these previous experiments that related $\mathrm{U}$ partitioning to increasing $\mathrm{pH}$ (and by inference, increasing $\left[\mathrm{CO}_{3}^{2-}\right]$ ) are consistent with our result of an inverse relationship between the $\mathrm{U} / \mathrm{Ca}$ ratio of aragonite and $\left[\mathrm{CO}_{3}^{2-}\right]$. However, our experiments are the first to isolate $\mathrm{pH}$ from $\left[\mathrm{CO}_{3}^{2-}\right]$ to show that it is the latter that influences the $\mathrm{U} / \mathrm{Ca}$ ratio of aragonite.

\subsubsection{Implications for interpreting $\mathrm{U} / \mathrm{Ca}$ in coral skeleton}

By experimentally precipitating aragonite from seawater under controlled conditions, we show conclusively for the first time that the $\mathrm{U} / \mathrm{Ca}$ ratio of abiogenic aragonite is strongly tied to $\left[\mathrm{CO}_{3}^{2-}\right]$ and is independent of $\mathrm{pH}$ and $\mathrm{T}$ between 20 and $40{ }^{\circ} \mathrm{C}$. While these results can be used to interpret $\mathrm{U} / \mathrm{Ca}$ of coral skeletons, it is important to recognize that coral aragonite is not precipitated directly from an infinite reservoir of seawater. Rather, there is strong evidence that skeleton is accreted in an isolated or semi-isolated space, and that the carbonate chemistry of the calcifying fluid is manipulated by the coral polyp during the biomineralization process (McConnaughey, 1989a,b; Gaetani and Cohen, 2006; Gagnon et al., 2007; Gaetani et al., 2011; Gagnon et al., 2012).

In corals, seawater is transported to an extracellular calcifying site between the base of the calicoblastic epithelium and the top of the existing skeleton or substrate. Evidence for the transport of seawater comes from tracer studies (Venn et al., 2011; Tambutté et al., 2012) and interpretation of skeletal geochemistry which is consistent 


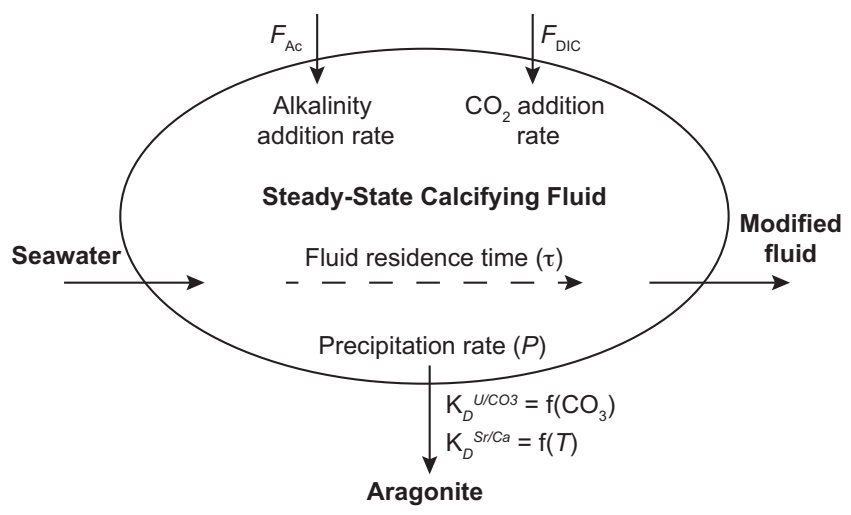

Figure 2-8: Schematic diagram of the steady-state biomineralization model. The calcifying fluid is assumed to be in steady-state and is replenished by seawater exchange. Volume of the calcifying fluid is assumed constant, so fluid is removed at the same rate seawater is added. Alkalinity $\left(\mathrm{A}_{C}\right)$ and DIC fluxes $(\boldsymbol{F})$, combined with aragonite precipitation, modify the carbonate chemistry of the calcifying fluid. Reservoirs are in bold and arrows indicate fluxes. $U$ and $\mathrm{Sr}$ partitioning are functions of $\left[\mathrm{CO}_{3}^{2-}\right]$ and $T$, respectively.

with seawater being the initial fluid for aragonite nucleation and growth (Cohen and McConnaughey, 2003; Gaetani and Cohen, 2006; Cohen and Gaetani, 2010; Gagnon et al., 2012). Once in the calcification site, physiological processes modify the carbonate chemistry of seawater to significantly enhance the rate of aragonite precipitation (Cohen and McConnaughey, 2003; Cohen et al., 2009; Trotter et al., 2011; Venn et al., 2011; Holcomb et al., 2014). Specifically, evidence from crystal microstructure and geochemistry (Cohen et al., 2009; Holcomb et al., 2014), corals cultured with pH-sensitive dye (Venn et al., 2011) and microelectrodes inserted into the calcifying space (Al-Horani et al., 2003) indicates that calcifying fluid $\mathrm{pH}$ and $\Omega_{\text {Arag }}$ are elevated above that of seawater, likely achieved through proton removal from the calcifying fluid (McConnaughey, 1989a,b; Al-Horani et al., 2003; Cohen and McConnaughey, 2003).

Because the carbonate chemistry of the calcifying fluid differs from seawater, the $\mathrm{U} / \mathrm{Ca}$ ratio of coral skeleton does not directly record seawater $\left[\mathrm{CO}_{3}^{2-}\right]$. This is evident from comparing the dependence of $\mathrm{U} / \mathrm{Ca}$ on $\left[\mathrm{CO}_{3}^{2-}\right]$ in our abiogenic experiments to $\mathrm{U} / \mathrm{Ca}$ ratios of shallow-water Porites corals, and the cold-water $\left(\sim 2-11^{\circ} \mathrm{C}\right)$ coral Desmophyllum dianthus (Anagnostou et al., 2011), along with the $\left[\mathrm{CO}_{3}^{2-}\right]$ of the seawater in which these corals lived (Fig. 2-7b). This simple comparison suggests that both Porites and $D$. dianthus calcifying fluid $\left[\mathrm{CO}_{3}^{2-}\right]$ is higher than that of seawater, and for $D$. dianthus its dependence on external seawater $\left[\mathrm{CO}_{3}^{2-}\right]$ is stronger than observed in the abiogenic experiments. 
To investigate further the relationship between coral $\mathrm{U} / \mathrm{Ca}$ and the composition of the calcifying fluid, we developed a steady-state model of a simplified coral biomineralization process in which seawater is constantly replenishing the calcifying space, alkalinity and DIC are constantly added, and aragonite precipitates from the fluid (Fig. 2-8; Appendix A). The model predicts the U/Ca ratio of coral aragonite based on the relative balance between alkalinity addition into the calcifying fluid and the ratio of alkalinity precipitated (removed) to alkalinity added, and using Eq. (2.10) to describe U partitioning between aragonite and seawater (Fig. 2-9). Model runs were carried out for different combinations of the amount of alkalinity added and the alkalinity precipitation to addition ratio in order to identify which combinations produced aragonite $\mathrm{U} / \mathrm{Ca}$ ratios in agreement with the range measured in Porites sp. coral skeletons ( 0.9-1.5 $\left.\mu \mathrm{mol} \mathrm{mol}^{-1}\right)$ (Wei et al., 2000; Quinn and Sampson, 2002; Felis et al., 2009), while also predicting realistic coral Sr/Ca ratios (9.68 - $9.90 \mathrm{mmol}$ $\left.\mathrm{mol}^{-1}\right)$.

A subset of the alkalinity addition and the precipitation to alkalinity addition ratio combinations that are consistent with coral $\mathrm{U} / \mathrm{Ca}$ and $\mathrm{Sr} / \mathrm{Ca}$ are also consistent with measurements of the coral calcifying fluid pH between 8.5 and 9.3 (Al-Horani et al., 2003; Venn et al., 2011; Holcomb et al., 2014). Further, the steady-state model predicts that $14-30 \%$ of $\mathrm{C}$ in coral skeleton is derived directly from seawater, consistent with ${ }^{45} \mathrm{Ca}$ and ${ }^{14} \mathrm{C}$ labeling experiments that found between $25 \%$ and $30 \%$ of precipitated C is derived from ambient seawater in the coral Stylophora pistillata (Furla et al., 2000). Thus, the steady-state model reconciles the U/Ca ratios measured in coral skeleton with our experimentally determined partitioning for abiogenic aragonite, and agrees with measurements of coral calcifying fluid $\mathrm{pH}$ and the relative amount of seawater $\mathrm{C}$ incorporated in coral skeleton. According to our biomineralization model, calcifying fluid [U] decreases with respect to seawater as $\mathrm{U}$ is incorporated into aragonite during precipitation within the semi-enclosed calcifying space. However, calcifying fluid $\left[\mathrm{CO}_{3}^{2-}\right]$ is elevated to several times that of seawater, above 700

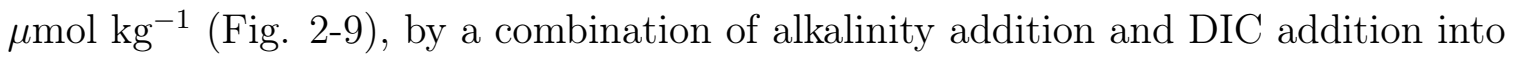
the calcifying space. The model predicts that alkalinity and DIC are elevated, and 


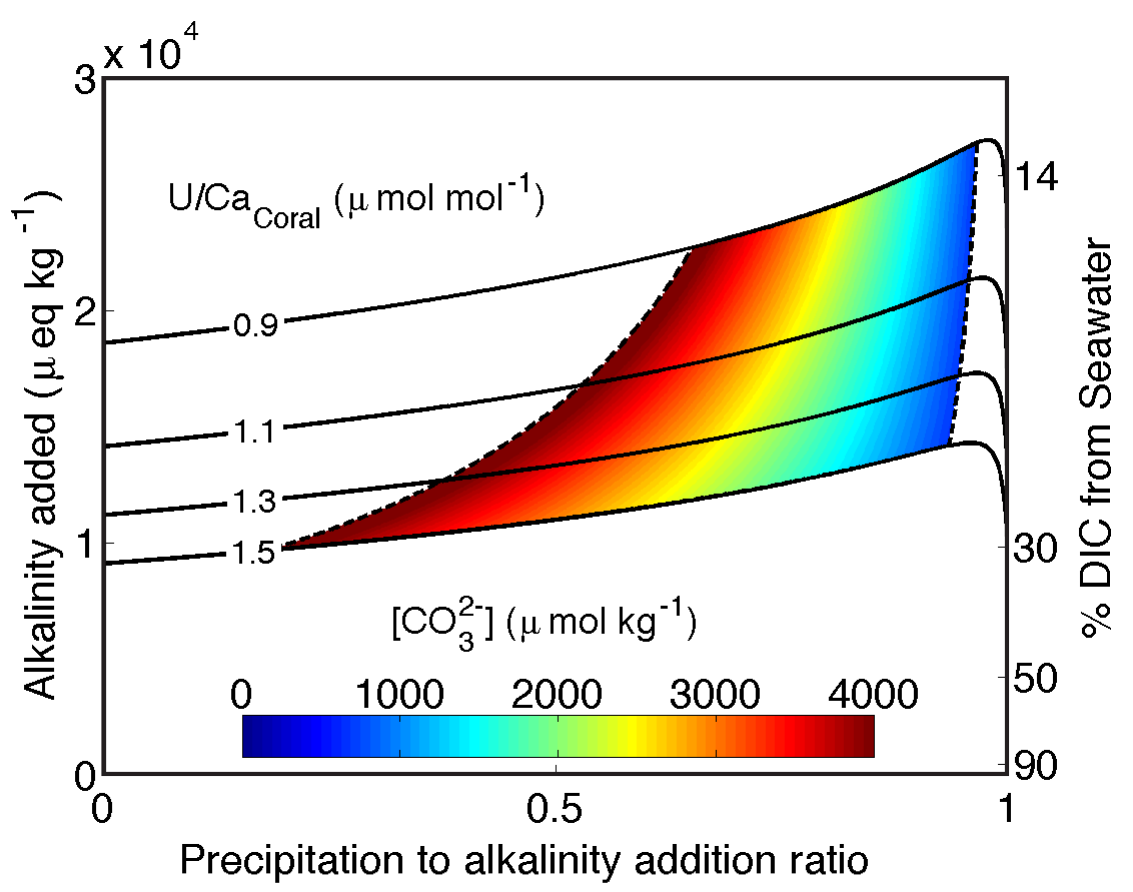

Figure 2-9: Results from steady-state biomineralization model. Predicted coral U/Ca ( $\mu \mathrm{mol} \mathrm{mol} \mathrm{mol}^{-1}$ and indicated by solid black contours) and $\left[\mathrm{CO}_{3}^{2-}\right]$ (colors) are functions of alkalinity addition and precipitation. Dashed lines indicate pH contours at 8.5 (right) and 9.3 (left) based on $\delta^{11} \mathrm{~B}$ of the skeleton (Holcomb et al., 2014), pH-sensitive dye studies (Venn et al., 2011), and microelectrode measurements of coral calcifying fluid pH (Al-Horani et al., 2003). $\left[\mathrm{CO}_{3}^{2-}\right]$ is colored only for combinations of the amount of alkalinity addition and the precipitation to alkalinity addition ratio that are consistent with measured coral $\mathrm{U} / \mathrm{Ca}\left(\mu \mathrm{mol} \mathrm{mol}^{-1}\right)$ and calcifying fluid $\mathrm{pH}(8.5$ - 9.3). The primary vertical axis is defined as the amount of alkalinity added during the residence time of a parcel of calcifying fluid, and the horizontal axis is the ratio of precipitation to alkalinity addition in the calcifying fluid. Secondary vertical axis shows percent DIC in coral skeleton derived directly from seawater as a function of alkalinity added.

$p \mathrm{CO}_{2}$ decreased, relative to seawater, while $\Omega_{\text {Arag }}$ is elevated to at least 11 (Table 2.4 ), consistent with calcifying fluid $\Omega_{\text {Arag }}$ estimated from the crystal aspect ratio of aragonite coral skeletons (Cohen et al., 2009). These results show that corals exert control over their calcifying fluid $\left[\mathrm{CO}_{3}^{2-}\right]$, and therefore strongly influence the $\mathrm{U} / \mathrm{Ca}$ ratios of their skeleton.

$\mathrm{U} / \mathrm{Ca}$ of corals has been investigated as a potential proxy for seawater $\left[\mathrm{CO}_{3}^{2-}\right]$. Our results imply that the utility of such a proxy will depend on whether corals maintain their calcifying fluid $\left[\mathrm{CO}_{3}^{2-}\right]$ in proportion to that of seawater. Evidence to date suggests that the $\mathrm{pH}$ of the coral calcifying fluid, and likely its $\left[\mathrm{CO}_{3}^{2-}\right]$, is proportional to that of the external seawater. Using boron isotopes as a $\mathrm{pH}$ proxy, McCulloch et al. 
Table 2.4: Range of coral calcifying fluid carbonate system parameters predicted by biomineralization model.

\begin{tabular}{lll}
\hline & $\min$ & $\max$ \\
\hline $\mathrm{CO}_{3}^{2-}\left(\mu \mathrm{mol} \mathrm{kg}^{-1}\right)$ & $0.7 \times 10$ & $4.2 \times 10$ \\
$\mathrm{TA}\left(\mu \mathrm{eq} \mathrm{kg}^{-1}\right)$ & $3.2 \times 10$ & $10.2 \times 10$ \\
$\mathrm{DIC}\left(\mu \mathrm{mol} \mathrm{kg}^{-1}\right)$ & $2.6 \times 10$ & $6.1 \times 10$ \\
$p \mathrm{CO}_{2}(\mu \mathrm{atm})$ & 24 & 150 \\
$\Omega_{\text {Arag }}$ & 22 & 68 \\
\hline
\end{tabular}

Notes: Calculations performed at salinity of 35 and temperature of $25{ }^{\circ} \mathrm{C}$. Minimum and maximum values correspond to the region consistent with calcifying fluid $\mathrm{U} / \mathrm{Ca}$ and $\mathrm{pH}$ (Fig. 2-9). $\Omega_{\text {Arag }}$ calculated assuming the $\mathrm{Ca}^{2+}$ concentration of the calcifying fluid is elevated above seawater by $10 \%$ to $11 \mathrm{mmol} \mathrm{kg}^{-1}$. (Al-Horani et al., 2003).

(2012) showed that coral calcifying fluid $\mathrm{pH}$ is positively correlated with seawater $\mathrm{pH}$. Further, U/Ca ratios of the cold-water coral D. dianthus collected across the Atlantic and Pacific basins track differences in seawater $\left[\mathrm{CO}_{3}^{2-}\right]$ (Anagnostou et al., 2011).

Our biomineralization model links coral $\mathrm{U} / \mathrm{Ca}$ with $\left[\mathrm{CO}_{3}^{2-}\right]$ of the calcifying fluid. Environmental and physiological factors that influence calcifying fluid $\left[\mathrm{CO}_{3}^{2-}\right]$ will thus be reflected in the $\mathrm{U} / \mathrm{Ca}$ ratio. Within this framework, $\mathrm{U} / \mathrm{Ca}$ serves as a potentially valuable tool to investigate how changes in climate and/or seawater chemistry influence the coral biomineralization process.

\subsection{Conclusions}

Abiogenic precipitation of aragonite from seawater was carried out under controlled carbonate chemistry conditions in experiments conducted across a range of $\mathrm{pH}$ and $\left[\mathrm{CO}_{3}^{2-}\right]$, and at different $T$. Our experiments confirm that in abiogenic aragonite, $\mathrm{Sr} / \mathrm{Ca}$ is affected by $T$, while also demonstrating that it is independent of carbonate chemistry. The $\mathrm{T}$ dependence of $\mathrm{Sr} / \mathrm{Ca}$ in our experiments agrees well with previous studies that were conducted with different methodologies. U/Ca in aragonite depends on $\left[\mathrm{CO}_{3}^{2-}\right]$, and is independent of $\mathrm{pH}$ and $T$. Using the framework of a newly developed biomineralization model, the $\mathrm{U} / \mathrm{Ca}$ ratio of coral skeleton provides a valuable tool to probe the sensitivity of coral biomineralization, specifically the $\left[\mathrm{CO}_{3}^{2-}\right]$ of the 
calcifying fluid, to changes in the environment in which the coral lives, such as rising temperatures and increasing seawater $\mathrm{CO}_{2}$ concentrations.

\section{Bibliography}

Al-Horani, F. A., Al-Moghrabi, S. M., De Beer, D., 2003. The mechanism of calcification and its relation to photosynthesis and respiration in the scleractinian coral Galaxea fascicularis. Marine Biology 142 (3), 419-426.

Anagnostou, E., Sherrell, R. M., Gagnon, A., LaVigne, M., Field, M. P., McDonough, W. F., 2011. Seawater nutrient and carbonate ion concentrations recorded as P/Ca, $\mathrm{Ba} / \mathrm{Ca}$, and $\mathrm{U} / \mathrm{Ca}$ in the deep-sea coral Desmophyllum dianthus. Geochimica et cosmochimica acta.

Armid, A., Asami, R., Fahmiati, T., Sheikh, M. A., Fujimura, H., Higuchi, T., Taira, E., Shinjo, R., Oomori, T., 2011. Seawater temperature proxies based on DSr, DMg, and DU from culture experiments using the branching coral Porites cylindrica. Geochimica et cosmochimica acta.

Armid, A., Takaesu, Y., Fahmiati, T., Yoshida, S., Hanashiro, R., Fujimura, H., Higuchi, T., Taira, E., Oomori, T., 2008. U/Ca as a possible proxy of carbonate system in coral reef. pp. 92-96.

Brahmi, C., Meibom, A., Smith, D. C., Stolarski, J., Auzoux-Bordenave, S., Nouet, J., Doumenc, D., Djediat, C., Domart-Coulon, I., 2010. Skeletal growth, ultrastructure and composition of the azooxanthellate scleractinian coral Balanophyllia regia. Coral Reefs 29 (1), 175-189.

Cardinal, D., Hamelin, B., Bard, E., Pätzold, J., 2001. Sr/Ca, U/Ca and $\delta 18 \mathrm{O}$ records in recent massive corals from Bermuda: relationships with sea surface temperature. Chemical Geology 176 (1), 213-233.

Cohen, A. L., Gaetani, G. A., 2010. Ion partitioning and the geochemistry of coral skeletons: solving the mystery of the vital effect. EMU Notes in Mineralogy 11, $377-397$.

Cohen, A. L., McConnaughey, T. A., 2003. Geochemical Perspectives on Coral Mineralization. Rev. Mineral. Geochem. 54 (1), 151-187.

Cohen, A. L., McCorkle, D. C., de Putron, S., Gaetani, G. A., Rose, K. A., 2009. Morphological and compositional changes in the skeletons of new coral recruits reared in acidified seawater: Insights into the biomineralization response to ocean acidification. Geochemistry Geophysics Geosystems 10 (1), Q07005. 
Dickson, A. G., Millero, F. J., 1987. A comparison of the equilibrium constants for the dissociation of carbonic acid in seawater media. Deep Sea Research Part A. Oceanographic Research Papers 34 (10), 1733-1743.

Dietzel, M., Gussone, N., Eisenhauer, A., 2004. Co-precipitation of Sr2+ and Ba2+ with aragonite by membrane diffusion of $\mathrm{CO} 2$ between 10 and $50 \mathrm{C}$. Chemical Geology 203 (1), 139-151.

Djogic, R., Sipos, L., Branica, M., 1986. Characterization of uranium (VI) in seawater. Limnology and Oceanography, 1122-1131.

Doerner, H. A., Hoskins, W. M., 1925. Co-Precipitation of Radium and Barium Sulfates. Journal of the American Chemical Society 47 (3), 662-675.

Dong, W., Brooks, S., 2006. Determination of the Formation Constants of Ternary Complexes of Uranyl and Carbonate with Alkaline Ba $2+$ ) Using Anion Exchange Method. Environmental science \& technology, 4689-4695.

Dormand, J. R., Prince, P. J., 1980. A family of embedded Runge-Kutta formulae. Journal of computational and applied mathematics 6 (1), 19-26.

Endrizzi, F., Rao, L., 2014. Chemical speciation of uranium(VI) in marine environments: complexation of calcium and magnesium ions with [(UO2 )(CO3 )3 ](4-) and the effect on the extraction of uranium from seawater. Chemistry (Weinheim an der Bergstrasse, Germany) 20 (44), 14499-506.

Felis, T., Suzuki, A., Kuhnert, H., Dima, M., Lohmann, G., Kawahata, H., 2009. Subtropical coral reveals abrupt early-twentieth-century freshening in the western North Pacific Ocean. Geology 37 (6), 527-530.

Furla, P., Galgani, I., Durand, I., Allemand, D., 2000. Sources and mechanisms of inorganic carbon transport for coral calcification and photosynthesis. Journal of Experimental Biology 203 (22), 3445-3457.

Gabitov, R. I., Gaetani, G. A., Watson, E. B., Cohen, A. L., Ehrlich, H. L., 2008. Experimental determination of growth rate effect on $\mathrm{U} 6+$ and $\mathrm{Mg} 2+$ partitioning between aragonite and fluid at elevated U6+ concentration. Geochimica et cosmochimica acta 72 (16), 4058-4068.

Gaetani, G. A., Cohen, A. L., 2006. Element partitioning during precipitation of aragonite from seawater: A framework for understanding paleoproxies. Geochimica et cosmochimica acta 70 (18), 4617-4634.

Gaetani, G. A., Cohen, A. L., Wang, Z., Crusius, J., 2011. Rayleigh-Based, MultiElement Coral Thermometry: a Biomineralization Approach to Developing Climate Proxies. Geochimica et cosmochimica acta 75, 1920-1932.

Gagnon, A. C., Adkins, J. F., Erez, J., 2012. Seawater transport during coral biomineralization. Earth and Planetary Science Letters 329, 150-161. 
Gagnon, A. C., Adkins, J. F., Fernandez, D. P., Robinson, L. F., 2007. Sr/Ca and $\mathrm{Mg} / \mathrm{Ca}$ vital effects correlated with skeletal architecture in a scleractinian deep-sea coral and the role of Rayleigh fractionation. Earth and Planetary Science Letters 261 (1), 280-295.

Gustafsson, J., Dässman, E., Bäckström, M., 2009. Towards a consistent geochemical model for prediction of uranium (VI) removal from groundwater by ferrihydrite. Applied Geochemistry.

Hathorne, E. C., Gagnon, A., Felis, T., Adkins, J., Asami, R., Boer, W., Caillon, N., Case, D., Cobb, K. M., Douville, E., DeMenocal, P., Eisenhauer, A., GarbeSchönberg, D., Geibert, W., Goldstein, S., Hughen, K., Inoue, M., Kawahata, H., Kölling, M., Cornec, F. L., Linsley, B. K., McGregor, H. V., Montagna, P., Nurhati, I. S., Quinn, T. M., Raddatz, J., Rebaubier, H., Robinson, L., Sadekov, A., Sherrell, R., Sinclair, D., Tudhope, A. W., Wei, G., Wong, H., Wu, H. C., You, C.-F., 2013. Interlaboratory study for coral $\mathrm{Sr} / \mathrm{Ca}$ and other element/Ca ratio measurements. Geochemistry, Geophysics, Geosystems 14 (9), 3730-3750.

Holcomb, M., Cohen, A. L., McCorkle, D. C., 2012. An investigation of the calcification response of the scleractinian coral Astrangia poculata to elevated pCO 2 and the effects of nutrients, zooxanthellae and gender. Biogeosciences 9, 29-39.

Holcomb, M., Venn, A. A., Tambutté, E., Tambutté, S., Allemand, D., Trotter, J., McCulloch, M., 2014. Coral calcifying fluid pH dictates response to ocean acidification. Scientific Reports 4.

Inoue, M., Suwa, R., Suzuki, A., Sakai, K., Kawahata, H., 2011. Effects of seawater pH on growth and skeletal U/Ca ratios of Acropora digitifera coral polyps. Geophysical Research Letters 38 (12), L12809.

Kalin, M., Wheeler, W. N., Meinrath, G., 2005. The removal of uranium from mining waste water using algal/microbial biomass. Journal of environmental radioactivity $78(2), 151-77$.

Keul, N., Langer, G., Nooijer, L. J., Nehrke, G., Reichart, G., Bijma, J., 2013. Incorporation of uranium in benthic foraminiferal calcite reflects seawater carbonate ion concentration. Geochemistry, Geophysics, Geosystems.

Kinsman, D. J. J., Holland, H. D., 1969. The co-precipitation of cations with CaCO3IV. The co-precipitation of Sr2+ with aragonite between 16 and 96 C. Geochimica et cosmochimica acta 33 (1), 1-17.

Kitano, Y., Oomori, T., 1971. The coprecipitation of uranium with calcium carbonate. J. Ocean. Soc. Jpn. 27 (1), 34-42.

Lagarias, J. C., Reeds, J. A., Wright, M. H., Wright, P. E., 1998. Convergence properties of the Nelder-Mead simplex method in low dimensions. SIAM Journal on optimization 9 (1), 112-147. 
Lewis, E., Wallace, D., Allison, L. J., 1998. Program developed for CO2 system calculations. Tech. rep.

Mann, D. K., Wong, G. T., 1993. 'Strongly bound' uranium in marine waters: occurrence and analytical implications. Marine Chemistry 42 (1), 25-37.

McConnaughey, T., 1989a. 13C and 180 isotopic disequilibrium in biological carbonates: I. Patterns. Geochimica et Cosmochimica Acta 53 (1), 151-162.

McConnaughey, T., 1989b. 13C and $18 \mathrm{O}$ isotopic disequilibrium in biological carbonates: II. In vitro simulation of kinetic isotope effects. Geochimica et Cosmochimica Acta 53 (1), 163-171.

McCulloch, M., Trotter, J., Montagna, P., Falter, J., Dunbar, R., Freiwald, A., Försterra, G., López Correa, M., Maier, C., Rüggeberg, A., 2012. Resilience of cold-water scleractinian corals to ocean acidification: Boron isotopic systematics of $\mathrm{pH}$ and saturation state up-regulation. Geochimica et cosmochimica acta 87, $21-34$.

Meece, D. E., Benninger, L. K., 1993. The coprecipitation of Pu and other radionuclides with CaCO3. Geochimica et cosmochimica acta 57 (7), 1447-1458.

Mehrbach, C., 1973. Measurement of the apparent dissociation constants of carbonic acid in seawater at atmospheric pressure.

Min, G. R., Edwards, R. L., Taylor, F. W., Recy, J., Gallup, C. D., Warren Beck, J., 1995. Annual cycles of U/Ca in coral skeletons and U/Ca thermometry. Geochimica et cosmochimica acta 59 (10), 2025-2042.

Ourbak, T., Corrège, T., Malaizé, B., Le Cornec, F., Charlier, K., Peypouquet, J. P., 2006. A highâĂRresolution investigation of temperature, salinity, and upwelling activity proxies in corals. Geochemistry, Geophysics, Geosystems 7 (3), Q03013.

Parkhurst, D. L., Appelo, C. A. J., 1999. User's guide to PHREEQC (Version 2): A computer program for speciation, batch-reaction, one-dimensional transport, and inverse geochemical calculations.

Quinn, T. M., Sampson, D. E., 2002. A Multiproxy Approach to Reconstructing Sea Surface Conditions Using Coral Skeleton Geochemistry. Paleoceanography 17 (4), 1062.

Raddatz, J., Rüggeberg, A., Flögel, S., Hathorne, E. C., Liebetrau, V., Eisenhauer, A., Dullo, W.-C., 2014. The influence of seawater $\mathrm{pH}$ on U/Ca ratios in the scleractinian cold-water coral Lophelia pertusa. Biogeosciences Discussions 10 (10), 15711-15733.

Reeder, R. J., Nugent, M., Lamble, G. M., Tait, C. D., Morris, D. E., 2000. Uranyl incorporation into calcite and aragonite: XAFS and luminescence studies. Environmental science \& technology 34 (4), 638-644. 
Robinson, L. F., Adkins, J. F., Fernandez, D. P., Burnett, D. S., Wang, S., Gagnon, A. C., Krakauer, N., 2006. Primary U distribution in scleractinian corals and its implications for U series dating. Geochemistry, Geophysics, Geosystems 7 (5).

Russell, A. D., Hönisch, B., Spero, H. J., Lea, D. W., 2004. Effects of seawater carbonate ion concentration and temperature on shell $\mathrm{U}, \mathrm{Mg}$, and $\mathrm{Sr}$ in cultured planktonic foraminifera. Geochimica et cosmochimica acta 68 (21), 4347-4361.

Saito, K., Miyauchi, T., 1982. Chemical forms of uranium in artificial seawater. Journal of Nuclear Science and Technology 19 (2), 145-150.

Shen, G. T., Dunbar, R. B., 1995. Environmental controls on uranium in reef corals. Geochimica et cosmochimica acta 59 (10), 2009-2024.

Sinclair, D. J., 2005. Correlated trace element 'vital effects' in tropical corals: a new geochemical tool for probing biomineralization. Geochimica et cosmochimica acta 69 (13), 3265-3284.

Tambutté, E., Tambutté, S., Segonds, N., Zoccola, D., Venn, A., Erez, J., Allemand, D., 2012. Calcein labelling and electrophysiology: insights on coral tissue permeability and calcification. Proceedings of the Royal Society B: Biological Sciences 279 (1726), 19-27.

Trotter, J., Montagna, P., McCulloch, M., Silenzi, S., Reynaud, S., Mortimer, G., Martin, S., Ferrier-Pagès, C., Gattuso, J. P., Rodolfo-Metalpa, R., 2011. Quantifying the $\mathrm{pH}$ 'vital effect' in the temperate zooxanthellate coral Cladocora caespitosa: Validation of the boron seawater $\mathrm{pH}$ proxy. Earth and Planetary Science Letters 303 (3), 163-173.

Venn, A., Tambutte, E., Holcomb, M., Allemand, D., Tambutte, S., 2011. Live tissue imaging shows reef corals elevate $\mathrm{pH}$ under their calcifying tissue relative to seawater. PLoS One 6 (5), e20013.

Watson, E. B., 2004. A conceptual model for near-surface kinetic controls on the traceelement and stable isotope composition of abiogenic calcite crystals. Geochimica et cosmochimica acta 68 (7), 1473-1488.

Wei, G., Sun, M., Li, X., Nie, B., 2000. Mg/Ca, Sr/Ca and U/Ca ratios of a porites coral from Sanya Bay, Hainan Island, South China Sea and their relationships to sea surface temperature. Palaeogeography, Palaeoclimatology, Palaeoecology 162 (1), $59-74$. 


\section{Chapter 3}

\section{Coral Sr-U Thermometry}

\subsection{Abstract}

Coral skeletons archive past climate variability with unrivaled temporal resolution. However, extraction of accurate temperature information from coral skeletons has been limited by "vital effects", which confound, and sometimes override, the temperature dependence of geochemical proxies. We present a new approach to coral paleothermometry based on results of abiogenic precipitation experiments interpreted within a framework provided by a quantitative model of the coral biomineralization process. In Chapter 2, I investigated temperature and carbonate chemistry controls on abiogenic partitioning of $\mathrm{Sr} / \mathrm{Ca}$ and $\mathrm{U} / \mathrm{Ca}$ between aragonite and seawater and modeled the sensitivity of skeletal composition to processes occurring at the site of calcification. The model predicts that temperature can be accurately reconstructed from coral skeleton by combining $\mathrm{Sr} / \mathrm{Ca}$ and $\mathrm{U} / \mathrm{Ca}$ ratios into a new proxy, which we refer to hereafter as the Sr-U thermometer. Here, we test the model predictions with measured $\mathrm{Sr} / \mathrm{Ca}$ and U/Ca ratios of fourteen Porites sp. corals collected from the tropical Pacific Ocean and the Red Sea, with a subset also analyzed using the boron

DeCarlo T.M., Gaetani G.A., Cohen A.L., Foster G.L., Alpert A.E., Stewert J., (2016). Coral Sr-U Thermometry. Paleoceanography 31, 626-638 
isotope $\left(\delta^{11} \mathrm{~B}\right) \mathrm{pH}$ proxy. Observed relationships among $\mathrm{Sr} / \mathrm{Ca}, \mathrm{U} / \mathrm{Ca}$, and $\delta^{11} \mathrm{~B}$, agree with model predictions, indicating that the model accounts for the key features of the coral biomineralization process. By calibrating to instrumental temperature records, we show that $\mathrm{Sr}-\mathrm{U}$ captures $93 \%$ of mean annual temperature variability $\left(26-30{ }^{\circ} \mathrm{C}\right)$ and has a standard deviation of prediction of $0.5{ }^{\circ} \mathrm{C}$, compared to $1{ }^{\circ} \mathrm{C}$ using $\mathrm{Sr} / \mathrm{Ca}$ alone. The $\mathrm{Sr}-\mathrm{U}$ thermometer may offer significantly improved reliability for reconstructing past ocean temperatures from coral skeletons.

\subsection{Introduction}

Since 1900, global mean surface temperatures have increased at an average rate of $0.08{ }^{\circ} \mathrm{C}$ per decade, and state-of-the-art general circulation models (GCMs) project further warming of $1-4{ }^{\circ} \mathrm{C}$ by the end of this century in response to anthropogenic greenhouse gas (GHG) emissions (Meehl et al., 2012; Stocker et al., 2013). These projections depend in large part on estimates of "climate sensitivity", the sensitivity of Earth's temperature to a doubling of atmospheric $\mathrm{CO}_{2}$, and there is substantial uncertainty in these estimates. Natural oscillations in atmospheric and oceanic circulation occurring on inter-annual (e.g. El Nino Southern Oscillation), multi-decadal (e.g. Pacific Decadal Oscillation), and centennial (e.g. the Little Ice Age) timescales can partially obscure climate sensitivity, and how these modes of variability interact with, and possibly change, under GHG forcing remain uncertain (Wittenberg, 2009; Stevenson et al., 2012; Emile-Geay et al., 2013; Li et al., 2013; Meehl et al., 2014). Multi-century long records of temperature can help to resolve these issues by enabling characterization of internal variability and isolation of secular temperature trends driven by external forcing (e.g. GHGs).

Direct observations of temperature, however, extend back only as far as the mid19th century (Smith et al., 2008). Furthermore, in regions such as the central tropical Pacific Ocean where sparse observations exist prior to 1950 (Giese and Ray, 2011), estimates of 20th century warming vary up to a factor of two (Nurhati et al., 2011; Solomon and Newman, 2012; Emile-Geay et al., 2013). These limits to the length 
and reliability of instrumental records make it difficult to constrain the range of natural variability, the degree of 20th century warming, and the climate sensitivity to GHG forcing. Accurate proxy temperature reconstructions offer the only way to extend the relatively short observational period further into the past and overcome the limitations of instrumental temperature records.

The skeletons of long-lived reef-building corals are a promising archive of this information. Distributed across the tropics at shallow water depths, corals are exposed to the sea surface temperature (SST), and accrete their skeletons in alternating highand low-density bands that provide intrinsic, high-resolution time markers extending hundreds of years into the past (Buddemeier et al., 1974). As corals grow, the geochemistry of their skeletal aragonite is sensitive to fluctuations in environmental conditions, including temperature. The most common coral-based temperature proxy currently in use is the $\mathrm{Sr} / \mathrm{Ca}$ thermometer, which exploits the inverse relationship between Sr/Ca and water temperature (Kinsman and Holland, 1969; Smith et al., 1979; Gaetani and Cohen, 2006; DeCarlo et al., 2015b). Typically, Sr/Ca ratios are first calibrated with modern instrumental SST records to establish a coral-specific Sr/Catemperature relationship, and then applied down-core to the older skeleton of the same coral, or in some cases to fossil corals, in order to reconstruct past SST (Smith et al., 1979; Felis et al., 2009; Hereid et al., 2013; Tierney et al., 2015; Toth et al., 2015).

However, problems arise because SST is not the only factor that influences coral $\mathrm{Sr} / \mathrm{Ca}$. The biomineralization process affects $\mathrm{Sr} / \mathrm{Ca}$ ratios and can do so independently of any changes in temperature. These biological influences are known as "vital effects", and are obvious in the comparison between coral and abiogenic aragonites. The temperature dependence of $\mathrm{Sr} / \mathrm{Ca}$ in coral skeleton (-0.05 to $-0.08 \mathrm{mmol} \mathrm{mol}^{-1}$ $\mathrm{Sr} / \mathrm{Ca}$ per $\left.{ }^{\circ} \mathrm{C}\right)$ is significantly stronger than that of abiogenic aragonite $(-0.039$ to $-0.044 \mathrm{mmol} \mathrm{mol}{ }^{-1} \mathrm{Sr} / \mathrm{Ca}$ per ${ }^{\circ} \mathrm{C}$ ) (Cohen et al., 2002; Gaetani and Cohen, 2006; Gaetani et al., 2011; DeCarlo et al., 2015b), and Sr/Ca-temperature relationships derived for different corals can vary widely. For Porites corals, a given $\mathrm{Sr} / \mathrm{Ca}$ ratio can correspond to a range of temperatures in excess of $10^{\circ} \mathrm{C}$ depending on which 
calibration equation is applied (Corrège, 2006; Gaetani et al., 2011). The influences of vital effects on $\mathrm{Sr} / \mathrm{Ca}$ ratios are also borne out in coral-based SST reconstructions, which repeatedly fail to capture observed temperature trends (Grove et al., 2013; Storz et al., 2013; Karnauskas et al., 2015; Alpert et al., 2016), and often decouple from observed SST by $>4{ }^{\circ} \mathrm{C}$ (Marshall and McCulloch, 2002; Felis et al., 2009; Wu et al., 2014).

Evidence suggests that these $\mathrm{Sr} / \mathrm{Ca}$ vital effects arise because corals accrete their skeleton within an isolated calcifying space (Cohen et al., 2006; Gaetani and Cohen, 2006). As aragonite crystals nucleate from the fluid within this space, the elemental composition of the fluid changes. Element ratios that are elevated in aragonite relative to the fluid (e.g. Sr/Ca) become progressively lower in the fluid as precipitation proceeds. This is known as Rayleigh fractionation (Cohen et al., 2006; Gaetani and Cohen, 2006). At a given temperature, the $\mathrm{Sr} / \mathrm{Ca}$ ratio of the aragonite will monotonically decrease as precipitation proceeds, in response to changes in the $\mathrm{Sr} / \mathrm{Ca}$ ratio of the calcifying fluid. Fluctuations in calcifying fluid carbonate ion concentration $\left(\left[\mathrm{CO}_{3}^{2-}\right]\right)$ likely drive variations in the amount of aragonite precipitation and thus cause fluctuations in the magnitude of the Rayleigh fractionation vital effect (Cohen et al., 2009; Gagnon et al., 2013). Accurate coral-based temperature proxies must therefore account for this process in order to isolate the temperature component of geochemical variability in the skeleton.

Abiogenic aragonite precipitation experiments showed that $\mathrm{U} / \mathrm{Ca}$ ratios of aragonite precipitated from seawater decrease as carbonate ion concentrations increase (DeCarlo et al., 2015b), and thus U/Ca ratios have potential to account for the vital effects that influence $\mathrm{Sr} / \mathrm{Ca}$ ratios. Here, we use coral $\mathrm{Sr} / \mathrm{Ca}$ and $\mathrm{U} / \mathrm{Ca}$ ratios interpreted within the context of the biomineralization model developed by DeCarlo et al. (2015b) to test the hypothesis that $\mathrm{Sr} / \mathrm{Ca}$ and U/Ca ratios can be used in tandem to accurately reconstruct past seawater temperature. We use data from fourteen corals collected in the tropical Pacific Ocean and the Red Sea, for which instrumental temperature data are available for comparison. In a subset of these corals, we also measured boron isotopic composition (a proxy for $\mathrm{pH}$ ) to test our hypothesis that vital 
effects in coral $\mathrm{Sr} / \mathrm{Ca}$ ratios arise from processes occurring during biomineralization.

\subsection{Methods}

\subsubsection{Coral records}

Coral skeleton cores were collected from massive Porites sp. colonies using underwater pneumatic drills. Two cores were collected from the central Red Sea near Jeddah, Saudi Arabia, two from Palmyra Atoll, four from Jarvis Island, and six in the Republic of Palau (Fig. 3-1). The mean annual temperatures at which each coral lived were acquired for time periods coincident with element ratio measurements using the NOAA Optimum Interpolation (OI) SST dataset (Reynolds et al., 2002). Temperature was compared between NOAA-OI and in situ temperature loggers deployed on each reef at the water depths of coral samples, and a correction was applied to NOAA-OI to account for any mean bias in temperature during overlapping time periods with the in situ loggers (Fig. 3-1).

Coral cores were scanned with a Siemens Volume Zoom Spiral Computerized Tomography (CT) scanner to determine skeletal density. Annual density banding was used to develop an age model for each coral (Fig. 3-2). Slabs were cut from cores with a water-cooled diamond wafering blade and cleaned for 15 minutes in an ultrasonic bath filled with $18.2 \mathrm{M} \Omega$ deionized water before drying at $60{ }^{\circ} \mathrm{C}$ for at least 24 hours. Subsamples of approximately $100 \mu \mathrm{g}$ were drilled from slabs with a fine-tipped, diamond-impregnated drillbit at 0.5 to $1.25 \mathrm{~mm}$ (approximately monthly) resolution. Sampling followed primary growth axes, tracking the growth paths of corallites.

\subsubsection{Trace elements}

Coral powders were dissolved in $5 \%$ trace metal grade nitric acid and counts of ${ }^{48} \mathrm{Ca}$, ${ }^{88} \mathrm{Sr}$, and ${ }^{238} \mathrm{U}$ were measured in low-resolution on a Thermo Element2 inductively coupled plasma mass spectrometer (ICP-MS) at Woods Hole Oceanographic Institution. External precision (one relative standard deviation) was $0.4 \%$ for $\mathrm{Sr} / \mathrm{Ca}$ and 
Figure 3-1: Coral sampling locations and sea surface temperatures. Map of climatological mean (19712000) sea surface temperature (SST) from the NOAA-OI dataset, with coral reef sampling locations indicated by white dots. (b) Satellite images of each reef, with locations of coral sampling indicated by red dots. (c) Comparisons between NOAA-OI and in situ logger temperatures for each coral sampling location. Horizontal bars indicate mean temperature for each location.

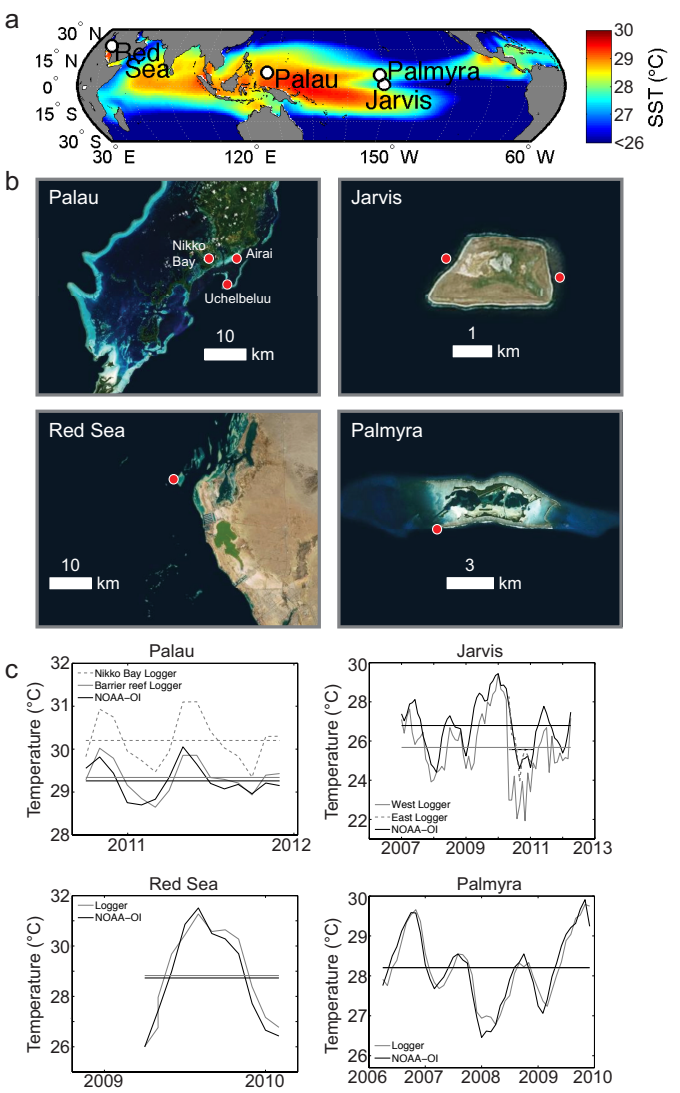

$0.8 \%$ for $\mathrm{U} / \mathrm{Ca}$, determined via repeated measurements of a secondary coral standard treated as a sample. Jarvis data are reported in Alpert et al. (2016). Element ratio measurements were standardized to the JCp-1 coral standard (Okai et al., 2002), which has nominal $\mathrm{Sr} / \mathrm{Ca}$ and $\mathrm{U} / \mathrm{Ca}$ ratios of $8.838 \pm 0.042 \mathrm{mmol} \mathrm{mol}{ }^{-1}$ and 1.192 $\pm 0.045 \mu \mathrm{mol} \mathrm{mol}{ }^{-1}$, respectively (Hathorne et al., 2013). JCp-1 analyses bracketed every eight sample analyses. Sr/Ca ratios were also measured repeatedly in standard materials derived from fish otoliths (Yoshinaga et al., 2000; Sturgeon et al., 2005) and the NBS-19 limestone (Fernandez et al., 2011) to ensure consistency of our Sr/Ca calibrations. As reported in Alpert et al. (2016), the batch of JCp-1 used in this study was compared to High Purity Standards single element standards gravimetrically mixed to simulate coral skeleton (40 ppm Ca with variable concentrations of $\mathrm{Mg}$, $\mathrm{Sr}, \mathrm{Ba}$, and U). Three aliquots of JCp-1 powder were dissolved and each analyzed in duplicate with resulting mean $\pm 1 \sigma$ for $\mathrm{Sr} / \mathrm{Ca}$ of $8.87 \pm 0.03 \mathrm{mmol} \mathrm{mol}^{-1}$ and $\mathrm{U} / \mathrm{Ca}$ of 1.23 $\pm 0.01 \mu \mathrm{mol} \mathrm{mol}{ }^{-1}$. 


\subsubsection{Boron isotopes}

Two pairs of corals, each pair collected from a single reef in Palau, were analyzed for boron isotopic composition. $\delta^{11} \mathrm{~B}$ was measured in splits of the same samples used for $\mathrm{Sr} / \mathrm{Ca}$ and $\mathrm{U} / \mathrm{Ca}$ analyses following the methods of Foster (2008) and Foster et al. (2013). Briefly, $\delta^{11} \mathrm{~B}$ splits were oxidatively cleaned at $80{ }^{\circ} \mathrm{C}$ in $1 \% \mathrm{H}_{2} \mathrm{O}_{2}$ (buffered with $0.1 \mathrm{M} \mathrm{NH}_{4} \mathrm{OH}$ ) in the clean lab of the University of Southampton. Oxidatively cleaned samples were then subjected to a weak acid leach and dissolved in a minimum volume of $0.5 \mathrm{M} \mathrm{HNO}_{3}$, and boron was then separated from the dissolved sample using Amberlite IRA 743 anion ex-

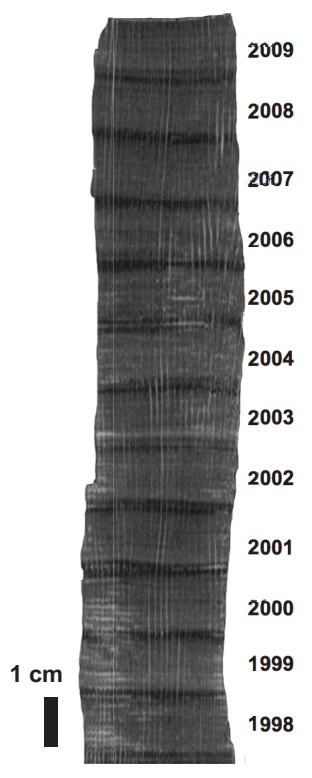

Figure 3-2: Computerized tomography (CT) scan of Palmyra 3 coral. Light (dark) shading indicates relatively high (low) density skeleton. The timescale is derived from annual density banding, visible as approximately horizontal alternating low- and high-density bands. change resin in $20 \mu \mathrm{l}$ micro-columns. The boron isotopic composition was determined using a Thermo Scientific Neptune multicollector ICP-MS at the University of Southampton normalized against NIST SRM 951. The long term precision (following Henehan et al. (2013)) was better than \pm $0.21 \%$ at $95 \%$ confidence, and during the course of this study repeat analysis of JCp-1 gave $\delta^{11} \mathrm{~B}$ of $24.2 \pm 0.2 \%$ at $95 \%$ confidence. Calcifying fluid $\mathrm{pH}$ was calculated from measured $\delta^{11} \mathrm{~B}_{\text {coral }}$ as

$$
p H_{E C F}=p K_{B}-\log \left(-\frac{\delta^{11} B_{\text {seawater }}-\delta^{11} B_{\text {coral }}}{\delta^{11} B_{\text {seawater }}-\alpha_{B} \delta^{11} B_{\text {coral }}-1000\left(\alpha_{B}-1\right)}\right)
$$

following Zeebe and Wolf-Gladrow (2001) where $\alpha \mathrm{B}$ is equal to 1.0272 (Klochko et al., 2006), pKB is estimated from temperature and salinity based on (Dickson, 1990), and $\delta^{11} \mathrm{~B}_{\text {seawater }}$ is assumed to be $39.6 \%$ (following Foster et al. (2010)) and 
representative of the calcifying fluid. For each coral we calculated the mean $\mathrm{pH}_{E C F}$ over 2008-2009 in order to facilitate comparison among corals.

\subsubsection{Statistics}

The relationship between $\mathrm{Sr} / \mathrm{Ca}$ and $\mathrm{U} / \mathrm{Ca}$ in our coral samples was examined using linear regression, and with analysis of covariance (ANCOVA) in which $\mathrm{Sr} / \mathrm{Ca}$ is the dependent variable, $\mathrm{U} / \mathrm{Ca}$ is the covariate, and coral colony is an independent factor. ANCOVA tests the significance of $\mathrm{Sr} / \mathrm{Ca}$ to $\mathrm{U} / \mathrm{Ca}$ correlation in our corals, while allowing the relationship between $\mathrm{Sr} / \mathrm{Ca}$ and $\mathrm{U} / \mathrm{Ca}$ to vary among coral colonies. We evaluated our data with ANCOVA both including and excluding an interaction between coral colony and $\mathrm{U} / \mathrm{Ca}$ (i.e. different slopes of $\mathrm{Sr} / \mathrm{Ca}$ vs $\mathrm{U} / \mathrm{Ca}$ for different corals). Differences in mean values of element ratios or calcifying fluid $\mathrm{pH}$ between corals were evaluated with two-sample t-tests. Linear regression was used to test for correlations between coral geochemical data and temperature. Throughout this study, significance is defined as $\mathrm{p}<0.05$.

\subsection{Results and Discussion}

\subsubsection{Modeling vital effects}

Vital effects on coral skeletal geochemistry are linked with the coral biomineralization process. Corals nucleate and grow the aragonite crystals that form their skeleton within an isolated space located beneath the calicoblastic epithelial cells (Barnes, 1970; Venn et al., 2011). Evidence from culture experiments with calcein dyes and solutions doped with biologically inert elements suggests that seawater transport into this space supplies the elements for crystallization (Gagnon et al., 2012; Tambutté et al., 2012). Corals modify the carbonate chemistry of the incoming seawater - likely via alkalinity pumping (Al-Horani et al., 2003; Cohen and McConnaughey, 2003; Venn et al., 2011) - to induce aragonite precipitation. The modified seawater from

which the aragonite crystals precipitate is referred to as the extracellular calcifying 


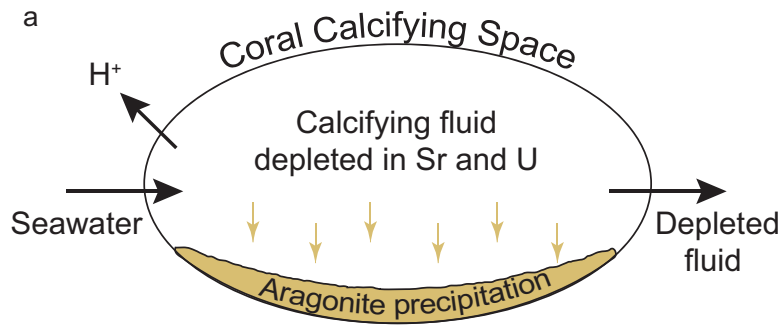

b
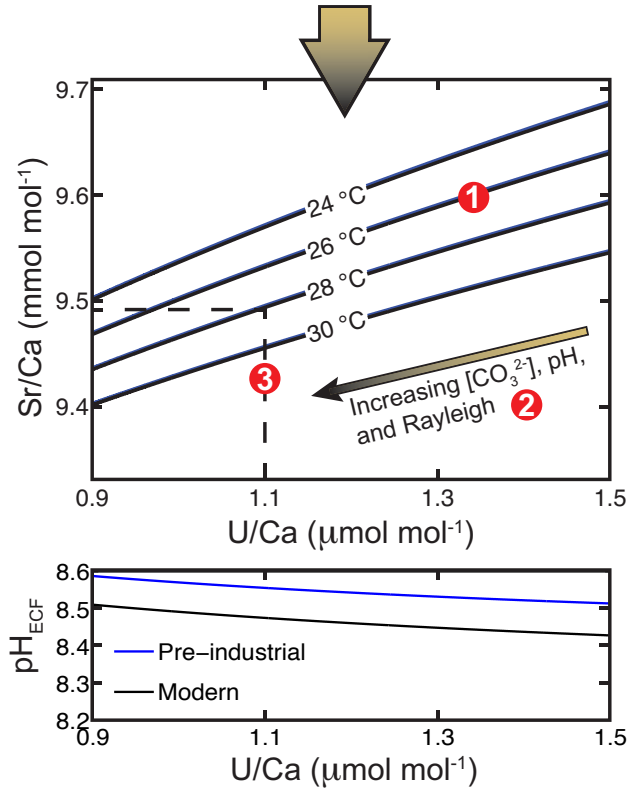

Figure 3-3: Coral biomineralization model. (a) Schematic diagram of semi-isolated coral calcifying space where the fluid in the space is supplied by seawater and elemental concentrations of the fluid are depleted relative to seawater as aragonite precipitates. Removal of protons $\left(\mathrm{H}^{+}\right)$from the fluid represents alkalinity pumping. (b) The model is evaluated between $24{ }^{\circ} \mathrm{C}$ and $30{ }^{\circ} \mathrm{C}$ (solid black lines, each representing the relationship between $\mathrm{Sr} / \mathrm{Ca}$ and $\mathrm{U} / \mathrm{Ca}$ at a specific temperature) and plotted for $\mathrm{U} / \mathrm{Ca}$ ratios consistent with Porites coral skeleton $\left(0.9\right.$ to $\left.1.5 \mu \mathrm{mol} \mathrm{mol}^{-1}\right)$. Red circles indicate the three predictions of the model that we test with coral data: (1) skeleton $\mathrm{Sr} / \mathrm{Ca}$ and $\mathrm{U} / \mathrm{Ca}$ ratios are positively correlated, (2) increasing Rayleigh fractionation, combined with increasing ECF $\mathbf{p H}$ and $\left[\mathrm{CO}_{3}^{2-}\right]$, decreases both skeleton $\mathrm{Sr} / \mathrm{Ca}$ and $\mathrm{U} / \mathrm{Ca}$ ratios, and (3) at a specific skeleton U/Ca ratio (dashed line), $\mathrm{Sr} / \mathrm{Ca}$ depends only upon temperature. (c) Predicted calcifying fluid $\mathrm{pH}$ related to the coral skeleton $\mathrm{U} / \mathrm{Ca}$ ratio at salinity 35 and temperature of $25{ }^{\circ} \mathrm{C}$, and assuming ambient seawater total alkalinity of $2300 \mu \mathrm{eq} \mathrm{kg}^{-1}$, and $\left[\mathrm{CO}_{3}^{2-}\right]$ of pre-industrial (blue) and today (black) bacon on Feely et al. (2009). While the absolute $\mathrm{pH}_{E C F}$ at a particular $\mathrm{U} / \mathrm{Ca}$ ratio is sensitive to ambient seawater $\left[\mathrm{CO}_{3}^{2-}\right]$, the model consistently predicts increasing $\mathrm{pH}_{E C F}$ with decreasing $\mathrm{Sr} / \mathrm{Ca}$ and $\mathrm{U} / \mathrm{Ca}$ ratios. Critically, though, seawater $\left[\mathrm{CO}_{3}^{2-}\right]$ has little influence on Sr-U temperature sensitivity, and the industrial $\left[\mathrm{CO}_{3}^{2-}\right]$ change would shift the isolines in panel (b) by the equivalent of only $0.03{ }^{\circ} \mathrm{C}$ (note that the blue and black lines representing the two $\left[\mathrm{CO}_{3}^{2-}\right]$ scenarios are partially overlapping in panel $b$ ). 
fluid (ECF). If calcification proceeds in an isolated (or semi-isolated) space, as microscopy (Venn et al., 2011) and geochemical (Cohen et al., 2006; Gaetani and Cohen, 2006) evidence suggests, there are critical implications for interpreting compositional variations in coral skeleton. Changes in the extent of precipitation from an isolated calcifying fluid would lead to variability of element ratios in coral skeletons as a result of Rayleigh fractionation. For many corals, more than half of the $\mathrm{Sr} / \mathrm{Ca}$ variance has been attributed to such vital effects (Cohen et al., 2002; Gaetani et al., 2011).

To shed light on the origin of vital effects, and to potentially quantify their effects on the composition of coral skeleton, we can look to co-variability among multiple element ratios. The basis for a multi-element approach to coral paleothermometry comes from laboratory experiments that determined the abiogenic controls on elemental partitioning between aragonite and seawater (Gaetani and Cohen, 2006; Gabitov et al., 2008), and modeling studies that placed abiogenic partitioning of multiple elements within a coral biomineralization framework (Cohen et al., 2006; Cohen and Gaetani, 2010; Gaetani et al., 2011; Gagnon et al., 2012). Subsequent coral culture and modeling studies identified the importance of carbonate chemistry changes occurring within the ECF on the elemental composition of the skeleton (Cohen et al., 2009; Gagnon et al., 2013; Tanaka et al., 2015). DeCarlo et al. (2015b) recently conducted laboratory precipitation experiments that characterized the abiogenic carbonate chemistry and temperature controls on $\mathrm{Sr} / \mathrm{Ca}$ and $\mathrm{U} / \mathrm{Ca}$ partitioning between aragonite and seawater. Previous studies consistently report positive correlations between coral Sr/Ca and U/Ca ratios (Cardinal et al., 2001; Hendy et al., 2002; Quinn and Sampson, 2002; Fallon et al., 2003; Sinclair and Risk, 2006; Felis et al., 2009, 2012; Jones et al., 2015). However, correlations between $\mathrm{Sr} / \mathrm{Ca}$ and $\mathrm{U} / \mathrm{Ca}$ are not found in experimentally precipitated abiogenic aragonite, in which $\mathrm{Sr} / \mathrm{Ca}$ is controlled by temperature and is insensitive to $\left[\mathrm{CO}_{3}^{2-}\right]$, whereas $\mathrm{U} / \mathrm{Ca}$ is controlled by $\left[\mathrm{CO}_{3}^{2-}\right]$ but is insensitive to temperature (DeCarlo et al., 2015b). The correlations between $\mathrm{Sr} / \mathrm{Ca}$ and $\mathrm{U} / \mathrm{Ca}$ in coral skeletons must, therefore, derive from processes occurring during biomineralization.

Quantitative, geochemical models of the coral biomineralization process provide a 
framework within which the environmental drivers of variability in skeletal composition (e.g. Sr/Ca sensitivity to SST) can be distinguished from vital effects that arise during biomineralization (e.g. influence of Rayleigh fractionation on $\mathrm{Sr} / \mathrm{Ca}$ ). DeCarlo et al. (2015b) developed a forward biomineralization model that successfully predicts $\mathrm{Sr} / \mathrm{Ca}$ and $\mathrm{U} / \mathrm{Ca}$ ratios of coral skeleton. Seawater exchange, alkalinity pumping, and aragonite precipitation modify the elemental composition of the ECF (Fig. 3-3). Together, these processes influence the $\mathrm{Sr} / \mathrm{Ca}$ and $\mathrm{U} / \mathrm{Ca}$ ratios of the skeleton via Rayleigh fractionation and changes in the ECF $\left[\mathrm{CO}_{3}^{2-}\right]$. This combination of factors produces a positive correlation between coral skeleton $\mathrm{Sr} / \mathrm{Ca}$ and $\mathrm{U} / \mathrm{Ca}$ ratios at a single temperature, such that a given coral $\mathrm{Sr} / \mathrm{Ca}$ ratio does not correspond to a unique temperature (Fig. 3-3). However, the modeling results also suggest a new approach for deriving temperature from coral skeletons. Since U/Ca is sensitive to Rayleigh fractionation - through variations in $\left[\mathrm{CO}_{3}^{2-}\right]$ - but not to temperature, a single $\mathrm{U} / \mathrm{Ca}$ ratio can serve as a benchmark with which to investigate variability in other element ratios independent of vital effects driven by Rayleigh fractionation. Comparing $\mathrm{Sr} / \mathrm{Ca}$ ratios that correspond to a single $\mathrm{U} / \mathrm{Ca}$ ratio should, therefore, isolate the temperature component of the $\mathrm{Sr} / \mathrm{Ca}$ signal (Fig. 3-3).

\subsubsection{Development of Sr-U thermometry}

The implication of the biomineralization model is that $\mathrm{Sr} / \mathrm{Ca}$ and $\mathrm{U} / \mathrm{Ca}$ ratios in coral skeleton can be combined to accurately reconstruct past seawater temperature. Here, we use our coral $\mathrm{Sr} / \mathrm{Ca}, \mathrm{U} / \mathrm{Ca}$, and $\delta^{11} \mathrm{~B}$ data to test predictions from the biomineralization model (Fig. 3-3). The first prediction of the model is that $\mathrm{Sr} / \mathrm{Ca}$ and $\mathrm{U} / \mathrm{Ca}$ are positively correlated within the skeleton of each coral colony. We found that $\mathrm{Sr} / \mathrm{Ca}$ is significantly positively correlated with $\mathrm{U} / \mathrm{Ca}$ (ANCOVA including interaction between coral colony and $\mathrm{U} / \mathrm{Ca}, \mathrm{r}^{2}=0.86$ ) across all of our corals (Fig. 3-4 and Fig. 3-5). According to the model, corals that experience the same temperature may have different $\mathrm{Sr} / \mathrm{Ca}$ ratios, but we expect that any differences in $\mathrm{Sr} / \mathrm{Ca}$ among such corals will be positively correlated with $\mathrm{U} / \mathrm{Ca}$ and inversely correlated with $\mathrm{pH}_{E C F}$ (Fig. 3-3). We tested this prediction using corals from Palau that have significantly 

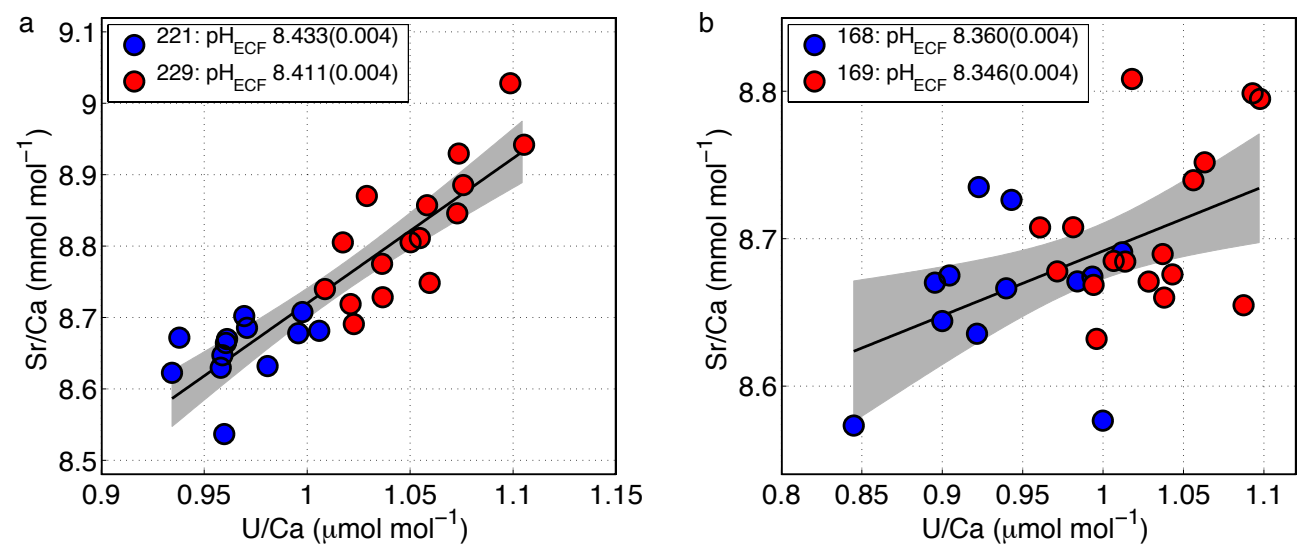

Figure 3-4: Vital effects in two pairs of corals, each pair collected from a single reef in Palau and sampled over the same time period (2008-2009). Property-property plots of $\mathrm{Sr} / \mathrm{Ca}$ and U/Ca ratios from corals collected in (a) Uchelbeluu (corals "221" and "229") and (b) Nikko Bay (corals "168" and "169"). Sr/Ca and U/Ca ratios of corals collected from a single reef are positively correlated. Within each pair of corals from a single reef, lower $\mathrm{Sr} / \mathrm{Ca}$ and $\mathrm{U} / \mathrm{Ca}$ ratios are correlated with elevated $\mathbf{p H} \mathrm{H}_{E C F}$. The $\mathbf{p H}_{E C F}$ is reported as the mean with the number in parentheses indicating the standard error of the mean. Solid black lines with gray bounds indicate least squares regression and $\mathbf{9 5 \%}$ confidence interval between $\mathrm{Sr} / \mathrm{Ca}$ and $\mathrm{U} / \mathrm{Ca}$ ratios. Note that the scales are different between the panels in order to aid interpretation of the plots.

different $\mathrm{Sr} / \mathrm{Ca}$ ratios even though they experienced the same temperatures (Fig. 34). Within each pair of corals collected from a single reef and sampled over the same time period (i.e. that experienced the same temperatures), the $\mathrm{pH}_{E C F}$ is significantly higher, and the $\mathrm{U} / \mathrm{Ca}$ ratio is significantly lower, in the coral with lower $\mathrm{Sr} / \mathrm{Ca}$ (Fig. 3-4), consistent with the model prediction (Fig. 3-3).

The key prediction of the model for paleothermometry is that $\mathrm{Sr} / \mathrm{Ca}$ and $\mathrm{U} / \mathrm{Ca}$ ratios can be used in tandem to accurately reconstruct temperature. In particular, here we test the prediction that the $\mathrm{Sr} / \mathrm{Ca}$ ratio of each coral corresponding to a specific U/Ca ratio correlates with temperature (Fig. 3-3). To do this, we select the median $\mathrm{U} / \mathrm{Ca}$ ratio among all of our coral data $\left(1.1 \mu \mathrm{mol} \mathrm{mol}{ }^{-1}\right)$, and we use the correlations between $\mathrm{Sr} / \mathrm{Ca}$ and $\mathrm{U} / \mathrm{Ca}$ to estimate the $\mathrm{Sr} / \mathrm{Ca}$ ratio, for each coral, that corresponds to this median $\mathrm{U} / \mathrm{Ca}$ ratio. We first regress $\mathrm{Sr} / \mathrm{Ca}$ with $\mathrm{U} / \mathrm{Ca}$, separately for each coral:

$$
\widehat{S r / C a}=m_{i}(U / C a)+b_{i}
$$

where $\widehat{S r / C} a$ is the estimated $\mathrm{Sr} / \mathrm{Ca}$ ratio from a given $\mathrm{U} / \mathrm{Ca}$ ratio, $\mathrm{m}_{i}$ is the slope 
and $\mathrm{b}_{i}$ is the intercept of ordinary least squares regression performed using the data of a single coral i with $\mathrm{Sr} / \mathrm{Ca}$ as the dependent variable and $\mathrm{U} / \mathrm{Ca}$ the independent variable. We then define $\mathrm{Sr}-\mathrm{U}$ for each coral as the estimated $\mathrm{Sr} / \mathrm{Ca}$ ratio at the median $\mathrm{U} / \mathrm{Ca}$ ratio:

$$
S r-U_{i}=m_{i}(1.1)+b_{i}
$$

where a single $\mathrm{Sr}-\mathrm{U}_{i}$ value is estimated for each coral, i. Sr-U from the fourteen corals is significantly correlated with mean annual temperature $\left(\mathrm{r}^{2}=0.93\right.$, Fig. 35 and Table 3.1), in agreement with the prediction of the biomineralization model. Temperature is predicted from $\mathrm{Sr}-\mathrm{U}$ according to the following calibration equation ( \pm 1 standard error of coefficients):

$$
\text { Temperature }\left({ }^{\circ} \mathrm{C}\right)=(-11 \pm 1)(\operatorname{Sr} U-9)+(28.1 \pm 0.1)
$$

where 9 is subtracted from $\mathrm{Sr}-\mathrm{U}$ to center the regression about zero. Whereas equations (3.2) and (3.3) are defined independently for each colony (i.e. the regression between $\mathrm{Sr} / \mathrm{Ca}$ and $\mathrm{U} / \mathrm{Ca}$ is based on a particular coral record), the temperature sensitivity of $\mathrm{Sr}-\mathrm{U}$ in equation (3.4) is calibrated with all fourteen corals in our dataset. The standard deviation of prediction of mean temperature for $\mathrm{Sr}-\mathrm{U}$ is $\pm 0.5^{\circ} \mathrm{C}$ and the root mean square error between observed and predicted temperature is $0.4^{\circ} \mathrm{C}$, approximately half of the uncertainty based on $\mathrm{Sr} / \mathrm{Ca}$ alone (Fig. 3-5).

In our ANCOVA, the intercept of the relationship between $\mathrm{Sr} / \mathrm{Ca}$ and $\mathrm{U} / \mathrm{Ca}$ varies greatly among coral colonies (explaining $58 \%$ of total $\mathrm{Sr} / \mathrm{Ca}$ variance). While differences in the slope of the $\mathrm{Sr} / \mathrm{Ca}$ and $\mathrm{U} / \mathrm{Ca}$ relationship (i.e. interaction between coral colony and $\mathrm{U} / \mathrm{Ca}$ ) are significant, the slopes vary only slightly (explaining $1 \%$ of total $\mathrm{Sr} / \mathrm{Ca}$ variance). This means that most (84\%) of $\mathrm{Sr} / \mathrm{Ca}$ variance is explained by regression to $\mathrm{U} / \mathrm{Ca}$ with a single slope applied to all corals, but with different intercepts (i.e. offsets in $\mathrm{Sr} / \mathrm{Ca}$ among corals). Including the interaction term is statistically robust, but it has potentially important ramifications for applying Sr-U outside of our calibration. The strength of the correlation between $\mathrm{Sr} / \mathrm{Ca}$ and $\mathrm{U} / \mathrm{Ca}$ influences the ordinary least squares slope, and thus, Sr-U could be sensitive to any effect of 
sampling resolution on the $\mathrm{r}^{2}$ between $\mathrm{Sr} / \mathrm{Ca}$ and $\mathrm{U} / \mathrm{Ca}$. Further, if we include the interaction term, we must define $\mathrm{Sr}-\mathrm{U}$ as the $\mathrm{Sr} / \mathrm{Ca}$ ratio predicted at a certain $\mathrm{U} / \mathrm{Ca}$ ratio, one that is within the range of our dataset. Extrapolation to higher or lower $\mathrm{U} / \mathrm{Ca}$ ratios would lead to small differences in the $\mathrm{Sr} / \mathrm{Ca}$ to U/Ca slope among corals having a disproportionally large effect on Sr-U. Alternatively, similar results are produced when $\mathrm{Sr}-\mathrm{U}$ is defined without the interaction term (i.e. the slope of $\mathrm{Sr} / \mathrm{Ca}$ and $\mathrm{U} / \mathrm{Ca}$ is the same for all corals), which is implemented by replacing equations (3.3) and (3.4) with equations (3.5) and (3.6), respectively:

$$
\begin{gathered}
S r U_{\text {parallel }}=\overline{\operatorname{Sr} / \mathrm{Ca}}-1.1107 \overline{\mathrm{U} / \mathrm{Ca}} \\
\text { Temperature }\left({ }^{\circ} \mathrm{C}\right)=(-10 \pm 1)\left(\operatorname{Sr} U_{\text {parallel }}-7.7\right)+(28.8 \pm 0.1)
\end{gathered}
$$

where overbars indicate means and $\mathrm{Sr} / \mathrm{Ca}$ and $\mathrm{U} / \mathrm{Ca}$ are in units of $\mathrm{mmol} \mathrm{mol}^{-1}$ and $\mu \mathrm{mol} \mathrm{mol}{ }^{-1}$, respectively.

The theoretical basis for $\mathrm{Sr}-\mathrm{U}$ thermometry is derived from the general relationships predicted by the model (Fig. 3-3), which are consistent with coral data (Fig. 3-4 and Fig. 3-5). Yet, it is critical to recognize that $\mathrm{Sr}-\mathrm{U}$ is empirically regressed against temperature in a core-top calibration, which has two important implications for its application to corals outside of our calibration dataset. First, seasonal temperature variability likely contributes, in part, to coral $\mathrm{Sr} / \mathrm{Ca}$ signals, so that the regression line fit between $\mathrm{Sr} / \mathrm{Ca}$ and $\mathrm{U} / \mathrm{Ca}$ for a particular coral (Eq. 3.2) captures this seasonal temperature variability in $\mathrm{Sr} / \mathrm{Ca}$ in addition to variability imposed by vital effects. For this reason, $\mathrm{Sr}-\mathrm{U}$ as defined here is correlated with mean annual temperature, and cannot yet be applied to reconstruct seasonal temperature variability. Second, we have defined $\mathrm{Sr}-\mathrm{U}$ over the temperature range $26{ }^{\circ} \mathrm{C}$ to $30{ }^{\circ} \mathrm{C}$ based on approximately monthly sampling of Porites skeletons for $\mathrm{Sr} / \mathrm{Ca}$ and $\mathrm{U} / \mathrm{Ca}$ ratios calibrated with the JCp-1 coral standard. Existing $\mathrm{Sr} / \mathrm{Ca}$ and U/Ca datasets from Diploria and Porites corals collected in the Atlantic and Pacific basins show correlations and slopes between these two ratios that are similar to those found in our fourteen corals (Table 3.1), suggesting that the link between $\mathrm{Sr} / \mathrm{Ca}$ and $\mathrm{U} / \mathrm{Ca}$ is a consistent feature of coral 
skeletons. However, only corals analyzed in this study are used to calibrate $\mathrm{Sr}-\mathrm{U}$ to temperature because previous paired measurements of modern coral $\mathrm{Sr} / \mathrm{Ca}$ and $\mathrm{U} / \mathrm{Ca}$ ratios are not traceable to $\mathrm{JCp}-1$. We hypothesize that $\mathrm{Sr}-\mathrm{U}$ is robust to a range of conditions, but we note that its accuracy for different coral genera, timescales, and mean annual temperatures outside of our calibration dataset should be validated with modern corals before application to paleo-reconstructions.

Sr-U thermometry uses $\mathrm{U} / \mathrm{Ca}$ ratios to account for the vital effects on $\mathrm{Sr} / \mathrm{Ca}$ that are driven by the carbonate chemistry, specifically the $\left[\mathrm{CO}_{3}^{2-}\right]$, of the ECF. While ECF $\left[\mathrm{CO}_{3}^{2-}\right]$ may be sensitive to seawater $\left[\mathrm{CO}_{3}^{2-}\right]$, our model and our coral data indicate that variability in seawater chemistry does not impact the fidelity of the Sr$\mathrm{U}$ thermometer. The modeled relationship between $\mathrm{pH}_{E C F}$ and $\mathrm{U} / \mathrm{Ca}$ is sensitive to ambient seawater chemistry (Fig. 3-3c), but the relationships among $\mathrm{Sr} / \mathrm{Ca}, \mathrm{U} / \mathrm{Ca}$, and temperature - for the most part - are not (Fig. 3-3b). Since the start of the industrial era, anthropogenic emissions have increased atmospheric $\mathrm{CO}_{2}$ from 280 to 400 ppmv, which has decreased seawater $\left[\mathrm{CO}_{3}^{2-}\right]$ by $40 \mathrm{~mol} \mu \mathrm{mol} \mathrm{kg}{ }^{-1}$ (Feely et al., 2009). Our model predicts that this $\left[\mathrm{CO}_{3}^{2-}\right]$ change alone has a negligible effect, less than $0.03{ }^{\circ} \mathrm{C}$, on the accuracy of $\mathrm{Sr}-\mathrm{U}$ thermometry (Fig. 3-3), because it is mostly overridden by changes within the coral ECF. In fact, the corals used in this study were collected from reefs spanning a range of seawater carbonate chemistry (DeCarlo et al., 2015a), including a two-fold difference in $\left[\mathrm{CO}_{3}^{2-}\right]$ from $141 \mu \mathrm{mol} \mathrm{\textrm {kg } ^ { - 1 }}$ in the

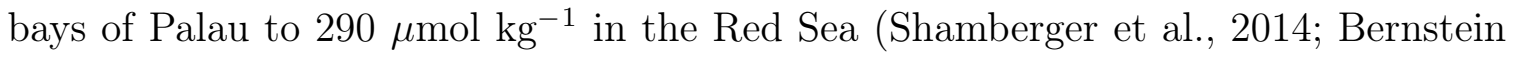
et al., 2016). Despite this wide range, residuals of the $\mathrm{Sr}-\mathrm{U}$ temperature calibration are not significantly correlated with seawater $\left[\mathrm{CO}_{3}^{2-}\right]\left(\mathrm{r}^{2}=0.01\right)$, further highlighting that $\mathrm{Sr}-\mathrm{U}$ is largely robust to changes in ambient seawater carbonate chemistry.

\subsubsection{Application of Sr-U to new corals}

The standard deviation of temperature prediction associated with Eq. 3.4 represents the uncertainty of the calibration equation for a precisely known $\mathrm{Sr}-\mathrm{U}$ value. Application of Sr- $\mathrm{U}$ to new corals, ones not included in the calibration, must also consider the uncertainty of the $\mathrm{Sr}-\mathrm{U}$ values themselves. Here we derive an expression for the 

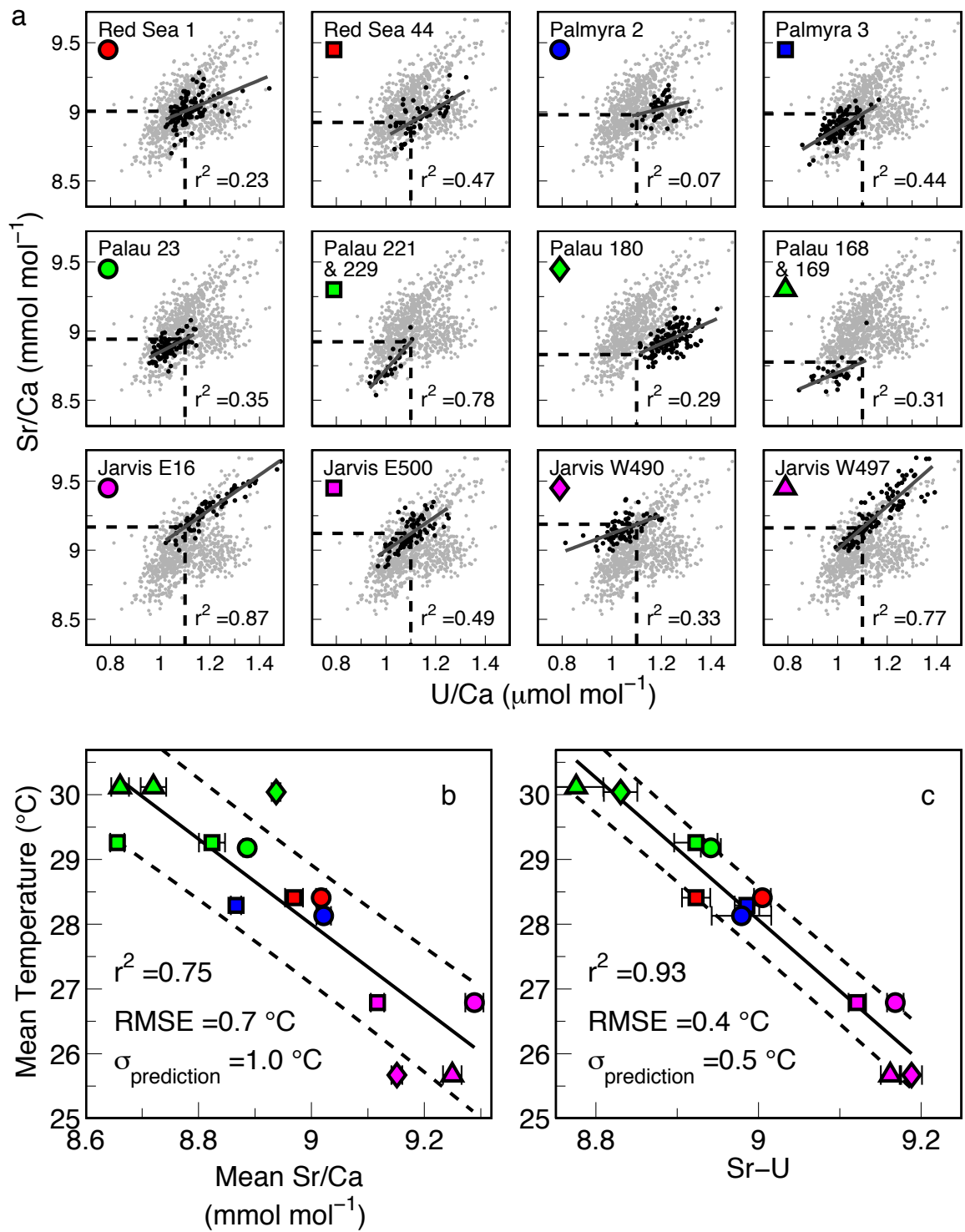

Figure 3-5: Calibration of the Sr-U thermometer. (a) Sr/Ca and U/Ca relationship of 14 Porites colonies from the Pacific Ocean and Red Sea. Each panel shows the data for a given coral in black and all other corals in light gray. The trend lines for each coral were fit by ordinary least squares regression between $\mathrm{Sr} / \mathrm{Ca}$ and U/Ca (solid dark gray lines). Sr-U is the estimated $\mathrm{Sr} / \mathrm{Ca}$ at $\mathrm{U} / \mathrm{Ca}$ of $1.1 \mu \mathrm{mol} \mathrm{mol}^{-1}$ (dashed lines). The colored symbol below the name of each coral indicates its position on the calibration plots in panels (b) and (c). Palau 221 and 229 (Uchelbeluu), and Palau 168 and 169 (Nikko Bay) data are each grouped from two separate corals collected on the same reefs because one coral from each location did not include U/Ca ratios as high as $1.1 \mu \mathrm{mol}$ $\mathrm{mol}^{-1}$ needed to define Sr-U. (b) Mean Sr/Ca and (c) Sr-U for each coral regressed with mean annual temperature. Dashed lines in (b) and (c) show $1 \sigma$ of prediction. Horizontal error bars in (b) show standard error of mean $\mathrm{Sr} / \mathrm{Ca}$, and in (c) show the 1 $\sigma$ uncertainty of the $\mathrm{Sr} / \mathrm{Ca}$ and $\mathrm{U} / \mathrm{Ca}$ regression at $\mathrm{U} / \mathrm{Ca}$ of $1.1 \mu \mathrm{mol} \mathrm{mol}^{-1}$. 


\begin{tabular}{|c|c|c|c|c|c|c|c|}
\hline Jarvis West W490 & $0.3696^{\circ} \mathrm{S} 160.0083^{\circ} \mathrm{W}$ & 7 & $25.67(2007-2012)$ & 0.81 & $1.3(0.4)$ & 9.19 & 9.15 \\
\hline Jarvis West W497 & $0.3689^{\circ} \mathrm{S} 160.0081^{\circ} \mathrm{W}$ & 16 & $25.67(2007-2012)$ & 0.64 & $1.9(0.2)$ & 9.16 & 9.25 \\
\hline Jarvis East 16 & $0.3739^{\circ} \mathrm{S} 159.9834^{\circ} \mathrm{W}$ & 5 & $26.79(2007-2012)$ & 0.86 & $1.4(0.1)$ & 9.17 & 9.29 \\
\hline Jarvis East E500 & $0.3715^{\circ} \mathrm{S} 159.9823^{\circ} \mathrm{W}$ & 5 & $26.79(2007-2012)$ & 0.49 & $2.2(0.5)$ & 9.12 & 9.12 \\
\hline Palmyra 2 & $5.8664^{\circ} \mathrm{N} 162.1095^{\circ} \mathrm{W}$ & 13 & $28.13(2006-2010)$ & 0.07 & $5(5)$ & 8.98 & 9.02 \\
\hline Palmyra 3 & $5.8664^{\circ} \mathrm{N} 162.1095^{\circ} \mathrm{W}$ & 13 & $28.29(1998-2010)$ & 0.44 & $2(0.4)$ & 8.99 & 8.89 \\
\hline Palau 23 (Airai) & $7.3321^{\circ} \mathrm{N} 134.5602^{\circ} \mathrm{E}$ & 4 & $29.18(1997-1999)$ & 0.36 & $2.0(0.5)$ & 8.94 & 8.89 \\
\hline Palau 221 (Uchelbeluu)* & $7.267^{\circ} \mathrm{N} 134.521^{\circ} \mathrm{E}$ & 5 & $29.26(2008-2009)$ & 0.79 & $2.5(0.5)$ & 8.92 & 8.66 \\
\hline Palau 229 (Uchelbeluu)* & $7.267^{\circ} \mathrm{N} 134.521^{\circ} \mathrm{E}$ & 5 & $29.26(2008-2009)$ & 0.79 & $2.5(0.5)$ & 8.92 & 8.82 \\
\hline Palau 180 (Nikko Bay) & $7.3248^{\circ} \mathrm{N} 134.4684^{\circ} \mathrm{E}$ & 6 & 30.04 (1997-1999) & 0.29 & $2.0(0.5)$ & 8.83 & 8.94 \\
\hline Palau 168 (Nikko Bay)* & $7.3248^{\circ} \mathrm{N} 134.4684^{\circ} \mathrm{E}$ & 3 & $30.12(2008-2009)$ & 0.30 & $1.8(0.9)$ & 8.78 & 8.66 \\
\hline Palau 169 (Nikko Bay)* & $7.3248^{\circ} \mathrm{N} 134.4684^{\circ} \mathrm{E}$ & 6 & $30.12(2008-2009)$ & 0.30 & $1.8(0.9)$ & 8.78 & 8.72 \\
\hline Bermuda N Rocks & $32.5^{\circ} \mathrm{N} 64.67^{\circ} \mathrm{W}$ & 24 & $23.0(1971-1984)$ & 0.67 & $2.1(0.4)$ & & \\
\hline Bermuda NE Breakers & $32.5^{\circ} \mathrm{N} 64.67^{\circ} \mathrm{W}$ & 11 & $22.9(1981-1984)$ & 0.49 & $1.9(0.6)$ & & \\
\hline \multicolumn{8}{|l|}{ [Ouinn and Sampson 2002] } \\
\hline New Caledonia & $22.48^{\circ} \mathrm{S} 116.47^{\circ} \mathrm{E}$ & 3 & $24.7(1968-1990)$ & 0.52 & $1.6(0.2)$ & & \\
\hline \multicolumn{8}{|l|}{ [Felis et al., 2009] } \\
\hline Japan & $27.106^{\circ} \mathrm{N} 142.194^{\circ} \mathrm{E}$ & 6 & $24.3(1982-1994)$ & 0.88 & $1.6(0.1)$ & & \\
\hline
\end{tabular}

Notes: Coefficient of determination $\left(\mathrm{r}^{2}\right)$ and slope $(\mathrm{m})$ of $\mathrm{Sr} / \mathrm{Ca}$ vs U/Ca relationship determined by reduced major axis regression. Parentheses indicate $\pm 2 \sigma$. All corals show significant relationships between $\mathrm{Sr} / \mathrm{Ca}$ and $\mathrm{U} / \mathrm{Ca}$.

* Palau 168 and 169 (Nikko Bay), and Palau 221 and 229 (Uchelbeluu) were grouped together to calculate Sr-U.

uncertainty of reconstructed temperature by propagating uncertainty of Sr-U values with the uncertainty of the calibration. We begin with the general form of linear regression, including error terms:

$$
y \pm \sigma_{y}=\left(m \pm \sigma_{m}\right)\left(x \pm \sigma_{x}\right)+\left(b \pm \sigma_{b}\right)
$$

The error of the slope term $(m x)$ is calculated by propagation of errors for multiplication:

$$
\sigma_{m x}=|m x| \sqrt{\left(\frac{\sigma_{m}}{m}\right)^{2}+\left(\frac{\sigma_{x}}{x}\right)^{2}}
$$

The error of the predicted values $\left(\sigma_{y}\right)$ is calculated by propagating error between the slope term $(m x)$ and the intercept term $(b)$ using propagation of errors rules for addition:

$$
\sigma_{m x+b}=\sigma_{y}=\sqrt{\sigma_{m x}^{2}+\sigma_{b}^{2}}=\sqrt{|m x|^{2}\left(\left(\frac{\sigma_{m}}{m}\right)^{2}+\left(\frac{\sigma_{x}}{x}\right)^{2}\right)+\sigma_{b}^{2}}
$$

For Sr-U thermometry (Eq. 3.4), the standard error (standard deviation) of the slope is \pm 1 (3.5) and the intercept is \pm 0.1 (0.35). Inserting the $\mathrm{Sr}-\mathrm{U}$ coefficients 
and uncertainties into Eq. 3.9 gives:

$$
\sigma_{\text {Temperature }}=\sqrt{|(11)(S r U-9)|^{2}\left(\left(\frac{3.5}{11}\right)^{2}+\left(\frac{\sigma_{S r U}}{S r U-9}\right)^{2}\right)+0.35^{2}}
$$

where $\sigma_{S r U}$ is the standard error of prediction of $\mathrm{Sr} / \mathrm{Ca}$ corresponding to U/Ca of $1.1 \mu \mathrm{mol} \mathrm{mol}{ }^{-1}$, which is calculated as:

$$
\sigma_{S r U}=\frac{\sqrt{|1.1 m|^{2}\left(\left(\frac{\sigma_{m}}{m}\right)^{2}+\left(\frac{\sigma_{U / C a}}{1.1}\right)^{2}\right)+\sigma_{b}^{2}}}{\sqrt{n}}
$$

where $m, \sigma_{m}, b, \sigma_{b}$ are the coefficients and their uncertainties, and $n$ is the number of data points, for ordinary least squares regression between $\mathrm{Sr} / \mathrm{Ca}$ and U/Ca, and $\sigma_{U / C a}$ is the measurement precision of $\mathrm{U} / \mathrm{Ca}$. Thus, given a set of $\mathrm{Sr} / \mathrm{Ca}$ and $\mathrm{U} / \mathrm{Ca}$ measurements, the steps to calculate temperature and its uncertainty are as follows. First, perform ordinary least squares regression between $\mathrm{Sr} / \mathrm{Ca}$ and $\mathrm{U} / \mathrm{Ca}$ (Eq. 3.2), and then calculate Sr-U (Eq. 3.3) and its uncertainty (Eq. 3.11). Next, convert Sr-U to temperature (Eq. 3.4) and calculate the uncertainty of the derived temperature (Eq. 3.10).

To illustrate how Sr-U uncertainties propagate to uncertainties in derived temperature, we reconstructed temperature time series using coral "Palmyra 03", the longest core in our study. We first calculated one Sr-U value for the entire 12-year record (i.e. the same Sr-U value for this coral reported in Table 1 and Figure 5). Next, we sub-divided the geochemical data and calculated $\mathrm{Sr}-\mathrm{U}$ in "windows" ranging in length from 2 to 6 years (Figure 3-6). When one Sr-U value was calculated for the full time series, $\sigma_{S r-U}$ was only 0.02 and the uncertainty in derived temperature $(0.5$ ${ }^{\circ} \mathrm{C}$ ) was close to the uncertainty of the calibration equation. However, as shorter windows were used, $\sigma_{S r U}$ increased. When $\mathrm{Sr}-\mathrm{U}$ was defined in 2-year windows, the average $\sigma_{S r U}$ was 0.12 , and the average $\sigma_{T e m p e r a t u r e}$ was $1.4^{\circ} \mathrm{C}$, more than twice the uncertainty of the calibration alone. These patterns highlight that when $\mathrm{Sr}-\mathrm{U}$ is used in down-core reconstructions, improving temperature precision comes at the cost of 
lowering temporal resolution. Applications of $\mathrm{Sr}-\mathrm{U}$ must therefore carefully weigh the balance between temperature and temporal resolution depending on the climate question to be investigated. While there is no strict rule for the shortest window that can be used (i.e. the highest temporal resolution), our Palmyra reconstruction indicates that windows of 3-years or longer are required to maintain $\sigma_{\text {Temperature }}$ less than $\pm 1{ }^{\circ} \mathrm{C}$.
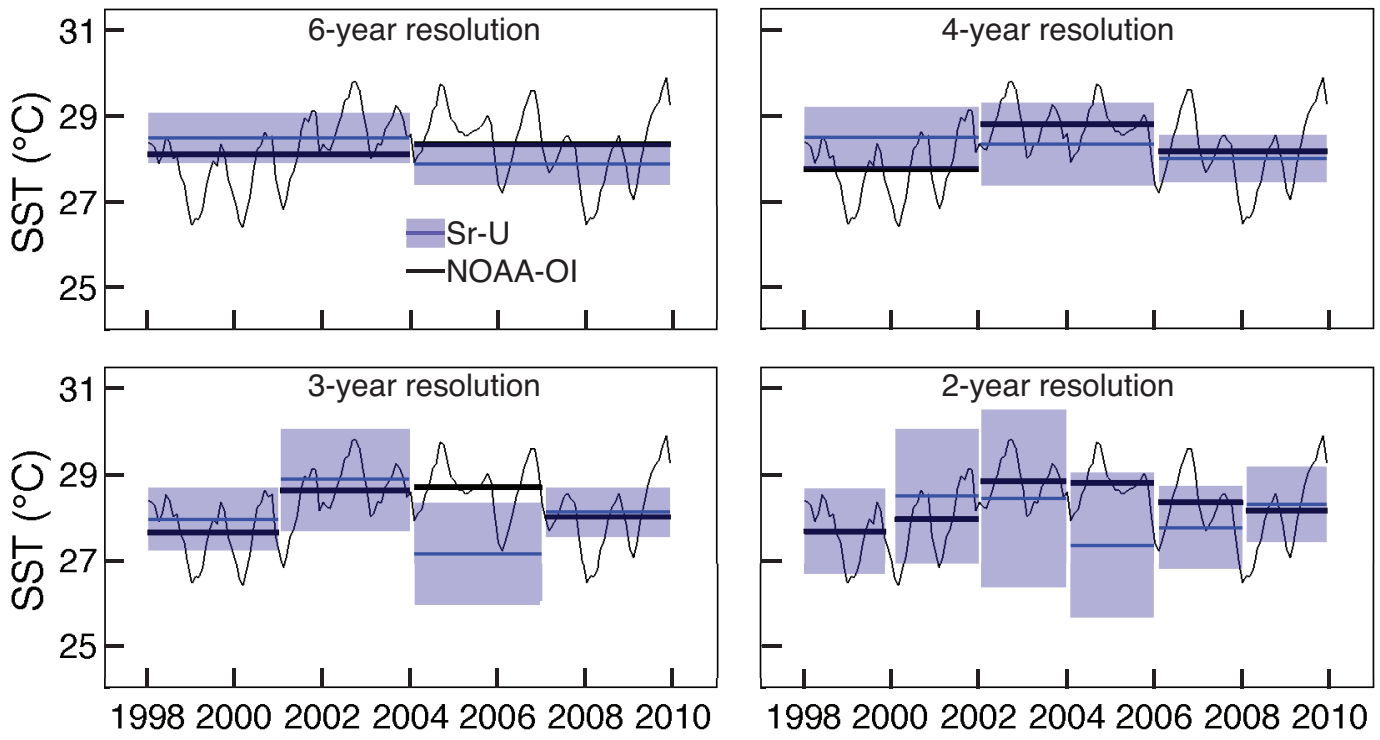

Figure 3-6: Sr-U applied in temporal domain. Blue lines indicate Sr-U reconstructed temperatures for Palmyra 03 coral, thin black indicates monthly NOAA-OI SST for the $1^{\circ}$ by $1^{\circ}$ grid-box surrounding Palmyra Atoll, and thick black indicates SST averaged over the same windows as Sr-U. Each panel shows the reconstruction for Sr-U defined with various window lengths ranging from 6 years (top left) to 2 years (bottom right). Blue shading indicates the $1 \sigma$ of temperature prediction for each window. The uncertainty of temperature prediction increases as window length decreases.

\subsubsection{Implications for coral paleothermometry}

Coral paleothermometry began with the discoveries that seasonal cycles of $\delta^{18} \mathrm{O}$ and Sr/Ca correlate with seawater temperature (Weber and Woodhead, 1972; Smith et al., 1979). The application of $\delta^{18} \mathrm{O}$ as a direct temperature proxy is limited by its sensitivity to salinity, leaving $\mathrm{Sr} / \mathrm{Ca}$ as the preferred temperature proxy. However, once temperature calibrations were developed for many different corals collected across the tropics, it became clear that a single relationship between temperature and $\mathrm{Sr} / \mathrm{Ca}$ 
does not exist (Corrège, 2006). A variety of approaches have been undertaken to resolve the non-temperature controls on coral $\mathrm{Sr} / \mathrm{Ca}$ ratios, including sampling along maximum growth axes (de Villiers et al., 1994), empirically regressing temperature to a variety of element ratios (Quinn and Sampson, 2002), correcting with coral growth rate (Saenger et al., 2008), accounting for "biosmoothing" (Gagan et al., 2012), and replicating time series (DeLong et al., 2013). However, no one approach has been able to resolve all of the $\mathrm{Sr} / \mathrm{Ca}$ vital effects, and $\mathrm{Sr} / \mathrm{Ca}$-based reconstructions continue to be plagued with unexplained decouplings from temperature (Wu et al., 2014).

Here, we present a new coral paleothermometer developed from a bottom-up approach. Laboratory experiments were used to evaluate the temperature and carbonate chemistry controls of aragonite $\mathrm{Sr} / \mathrm{Ca}$ and $\mathrm{U} / \mathrm{Ca}$ ratios, in the absence of any influence from the coral polyp (DeCarlo et al., 2015a). The abiogenic partitioning results were then placed within the framework of a biomineralization model to understand how corals influence these element ratios while building their skeletons. Importantly, the model makes testable predictions of the relationships among coral skeleton $\mathrm{Sr} / \mathrm{Ca}$ and $\mathrm{U} / \mathrm{Ca}$ ratios, and $\mathrm{pH}_{E C F}$ (Fig. 3-3), even though there are no correlations among these variables in experimentally precipitated abiogenic aragonite (DeCarlo et al., 2015a). These predictions are borne out in the composition of coral skeletons collected from different reefs across the Pacific Ocean and Red Sea (Fig. 3-4 and Fig. 3-5). The agreement between the model predictions and the coral data show that by combining information from $\mathrm{Sr} / \mathrm{Ca}$ and $\mathrm{U} / \mathrm{Ca}$ ratios, we are capturing the essential elements of the biomineralization process that influence the elemental composition of the skeleton.

Sr-U offers a new approach to coral paleothermometry that is based on our understanding of the biomineralization process. Coral $\mathrm{Sr} / \mathrm{Ca}$ ratios are sensitive to temperature, but that influence is subordinate to vital effects, which produce a range of Sr/Ca-temperature relationships (Fig. 3-3). With the Sr-U thermometer, we incorporate information from two element ratios that are sensitive to different aspects of the biomineralization process - $\mathrm{Sr} / \mathrm{Ca}$, which is sensitive to temperature but also influenced by "vital effects" and U/Ca, which records vital effects but is insensitive 
to temperature. In this way, $\mathrm{U} / \mathrm{Ca}$ ratios can be used to normalize $\mathrm{Sr} / \mathrm{Ca}$ ratios to a single temperature. Sr-U thermometry combines the temperature sensitivity of $\mathrm{Sr} / \mathrm{Ca}$ with the vital effect sensitivity of $\mathrm{U} / \mathrm{Ca}$ to extract temperature information from coral skeleton with accuracy not obtained by any other geochemical approach (Fig. 3-5).

The utility of a temperature proxy is judged on its ability to provide accurate temperature information prior to the beginning of instrumental records. Currently, reconstruction of SST several centuries or more into the past is performed using $\mathrm{Sr} / \mathrm{Ca}$ calibrations developed with modern corals and applied to fossil samples (DeLong et al., 2010; Hereid et al., 2013; Toth et al., 2015). This approach is subject to significant uncertainty as a result of the wide variability in $\mathrm{Sr} / \mathrm{Ca}$-temperature relationships derived from coral colonies living at the same temperatures (Fig. 3-4). For this reason, Sr-U thermometry may prove particularly valuable for predicting SST from fossil corals that lack a modern calibration period. The ability of the Sr-U thermometer to accurately predict absolute temperature from different corals with a single calibration equation, applicable over a broad spatial scale, separates it from thermometers based on $\mathrm{Sr} / \mathrm{Ca}$ alone.

Proxy reconstructions of past climate variability assume that the relationship between the proxy and the climate variable of interest is constant with respect to space and time. Coral $\mathrm{Sr} / \mathrm{Ca}$ paleothermometry violates this assumption due to the influence of vital effects on $\mathrm{Sr} / \mathrm{Ca}$-temperature relationships within the skeleton of single colonies. Decoupling (or "breakdown") of the relationship between $\mathrm{Sr} / \mathrm{Ca}$ and SST has been observed in several studies (Marshall and McCulloch, 2002; Felis et al., 2009; Wu et al., 2014). Perhaps the most drastic Sr/Ca breakdown was observed by Felis et al. (2009), in which $\mathrm{Sr} / \mathrm{Ca}$ ratios of a coral from the northwest Pacific implied that 1995-2000 was the coolest period of the 20th century, when in fact it was the warmest. Critically, this $\mathrm{Sr} / \mathrm{Ca}$ breakdown is accompanied by a positive correlation with U/Ca ratios (Felis et al., 2009). Our model explains this breakdown: corals may shift along the $\mathrm{Sr} / \mathrm{Ca}$ and U/Ca trajectory driven by "vital effects", even in the absence of temperature changes (Fig. 3-3). The positive correlation between $\mathrm{Sr} / \mathrm{Ca}$ and $\mathrm{U} / \mathrm{Ca}$ 
reported by Felis et al. (2009) suggests that observed Sr/Ca breakdowns are actually temporal variations in the coral biomineralization process. This likely explains why many existing $\mathrm{Sr} / \mathrm{Ca}$ records diverge from instrumental SST (Grove et al., 2013; Storz et al., 2013; Wu et al., 2014), and potentially influences $\mathrm{Sr} / \mathrm{Ca}$ records extended prior to the instrumental record for which no independent, direct observations of SST are available for comparison. When $\mathrm{Sr} / \mathrm{Ca}$ breakdowns are observed during recent decades, instrumental SST allows us to identify that the $\mathrm{Sr} / \mathrm{Ca}$ thermometer failed (Felis et al., 2009; Grove et al., 2013; Storz et al., 2013; Wu et al., 2014). It is important to recognize, however, that when $\mathrm{Sr} / \mathrm{Ca}$ is extended into the paleo-record, a $\mathrm{Sr} / \mathrm{Ca}$ breakdown cannot be distinguished from a true temperature change unless coupled with $\mathrm{U} / \mathrm{Ca}$ ratios to calculate $\mathrm{Sr}-\mathrm{U}$.

\subsection{Conclusion}

Coral skeletons are promising archives for high-resolution reconstructions of climate changes in the ocean over the past several millennia. However, application of geochemical temperature proxies - such as $\mathrm{Sr} / \mathrm{Ca}$ - has proven difficult due to the confounding influence of physiological vital effects. Here we present a new coral paleothermometer, Sr-U, which uses $\mathrm{U} / \mathrm{Ca}$ ratios to account for the influence of vital effects on $\mathrm{Sr} / \mathrm{Ca}$-temperature relationships. This approach significantly improves the accuracy of reconstructed temperature from coral skeleton. We calibrated $\mathrm{Sr}-\mathrm{U}$ to temperature using a new dataset of $\mathrm{Sr} / \mathrm{Ca}$ and $\mathrm{U} / \mathrm{Ca}$ ratios measured in fourteen corals collected in the Pacific Ocean and the Red Sea spanning a mean annual temperature range of 26 ${ }^{\circ} \mathrm{C}$ to $30{ }^{\circ} \mathrm{C}$. Sr-U thermometry has a standard deviation of prediction of only $0.5{ }^{\circ} \mathrm{C}$, which is twice the accuracy compared to using $\mathrm{Sr} / \mathrm{Ca}$ alone. Coral skeleton $\mathrm{Sr} / \mathrm{Ca}$ and $\mathrm{U} / \mathrm{Ca}$ ratios are routinely measured by ICP-MS, making the $\mathrm{Sr}-\mathrm{U}$ thermometer readily available to perform temperature reconstructions. With the improved accuracy and applicability of a single calibration equation to individual corals collected from different locations, Sr-U thermometry has great potential for extending our limited instrumental temperature records in the ocean. 


\section{Bibliography}

Al-Horani, F. A., Al-Moghrabi, S. M., De Beer, D., 2003. The mechanism of calcification and its relation to photosynthesis and respiration in the scleractinian coral Galaxea fascicularis. Marine Biology 142 (3), 419-426.

Alpert, A. E., Cohen, A. L., Oppo, D. W., DeCarlo, T. M., Gove, J. M., Young, C. W., 2016. Comparison of equatorial Pacific sea surface variability and trends with $\mathrm{Sr} / \mathrm{Ca}$ records from multiple corals. Paleoceanography 31, 252-265.

Barnes, D. J., 1970. Coral skeletons: an explanation of their growth and structure. Science 170 (3964), 1305-1308.

Bernstein, W. N., Hughen, K. A., Langdon, C., McCorkle, D. C., Lentz, S. J., 2016. Environmental controls on daytime net community calcification on a Red Sea reef flat. Coral Reefs 35 (2), 697-711.

Buddemeier, R. W., Maragos, J. E., Knutson, D. W., 1974. Radiographic studies of reef coral exoskeletons: rates and patterns of coral growth. J. Exp. Mar. Biol. Ecol. 14 (2), 179-199.

Cardinal, D., Hamelin, B., Bard, E., Pätzold, J., 2001. Sr/Ca, U/Ca and $\delta 18 \mathrm{O}$ records in recent massive corals from Bermuda: relationships with sea surface temperature. Chemical Geology 176 (1), 213-233.

Cohen, A. L., Gaetani, G. A., 2010. Ion partitioning and the geochemistry of coral skeletons: solving the mystery of the vital effect. EMU Notes in Mineralogy 11, $377-397$.

Cohen, A. L., Gaetani, G. A., Lundälv, T., Corliss, B. H., George, R. Y., 2006. Compositional variability in a cold-water scleractinian, Lophelia pertusa: new insights into 'vital effects'. Geochemistry Geophysics Geosystems 7 (12), Q12004.

Cohen, A. L., McConnaughey, T. A., 2003. Geochemical Perspectives on Coral Mineralization. Rev. Mineral. Geochem. 54 (1), 151-187.

Cohen, A. L., McCorkle, D. C., de Putron, S., Gaetani, G. A., Rose, K. A., 2009. Morphological and compositional changes in the skeletons of new coral recruits reared in acidified seawater: Insights into the biomineralization response to ocean acidification. Geochemistry Geophysics Geosystems 10 (1), Q07005.

Cohen, A. L., Owens, K. E., Layne, G. D., Shimizu, N., 2002. The Effect of Algal Symbionts on the Accuracy of $\mathrm{Sr} / \mathrm{Ca}$ Paleotemperatures from Coral. Science 296 (5566), 331-333.

Corrège, T., 2006. Sea surface temperature and salinity reconstruction from coral geochemical tracers. Palaeogeography, Palaeoclimatology, Palaeoecology 232 (2), 408-428. 
de Villiers, S., Shen, G. T., Nelson, B. K., 1994. The -temperature relationship in coralline aragonite: Influence of variability in and skeletal growth parameters. Geochimica et Cosmochimica Acta 58 (1), 197-208.

DeCarlo, T. M., Cohen, A. L., Barkley, H. C., Cobban, Q., Young, C., Shamberger, K. E., Brainard, R. E., Golbuu, Y., 2015a. Coral macrobioerosion is accelerated by ocean acidification and nutrients. Geology 43 (1), 7-10.

DeCarlo, T. M., Gaetani, G. A., Holcomb, M., Cohen, A. L., 2015b. Experimental determination of factors controlling $\mathrm{U} / \mathrm{Ca}$ of aragonite precipitated from seawater: implications for interpreting coral skeleton. Geochimica et cosmochimica acta 162, $151-165$.

DeLong, K. L., Quinn, T. M., Shen, C., Lin, K., 2010. A snapshot of climate variability at Tahiti at 9.5 ka using a fossil coral from IODP Expedition 310. Geochemistry Geophysics Geosystems 11 (6), Q06005.

DeLong, K. L., Quinn, T. M., Taylor, F. W., Shen, C., Lin, K., 2013. Improving coralbase paleoclimate reconstructions by replicating 350years of coral $\mathrm{Sr} / \mathrm{Ca}$ variations. Palaeogeography, Palaeoclimatology, Palaeoecology 373, 6-24.

Dickson, A. G., 1990. Standard potential of the reaction: $\mathrm{AgCl}(\mathrm{s})+12 \mathrm{H} 2(\mathrm{~g})=\mathrm{Ag}$ $(\mathrm{s})+\mathrm{HCl}(\mathrm{aq})$, and and the standard acidity constant of the ion HSO4- in synthetic sea water from 273.15 to $318.15 \mathrm{~K}$. The Journal of Chemical Thermodynamics $22(2), 113-127$.

Emile-Geay, J., Cobb, K. M., Mann, M. E., Wittenberg, A. T., 2013. Estimating central equatorial Pacific SST variability over the past millennium. Part I: methodology and validation. Journal of Climate 26 (7), 2302-2328.

Fallon, S. J., McCulloch, M. T., Alibert, C., 2003. Examining water temperature proxies in Porites corals from the Great Barrier Reef: a cross-shelf comparison. Coral Reefs 22 (4), 389-404.

Feely, R. A., Doney, S. C., Cooley, S. R., 2009. Ocean acidification: present conditions and future changes in a high-CO2 world. Oceanography 22 (4), 37-47.

Felis, T., Merkel, U., Asami, R., Deschamps, P., Hathorne, E., Kölling, M., Bard, E., Cabioch, G., Durand, N., Prange, M., 2012. Pronounced interannual variability in tropical South Pacific temperatures during Heinrich Stadial 1. Nature Communications 3,965 .

Felis, T., Suzuki, A., Kuhnert, H., Dima, M., Lohmann, G., Kawahata, H., 2009. Subtropical coral reveals abrupt early-twentieth-century freshening in the western North Pacific Ocean. Geology 37 (6), 527-530.

Fernandez, D. P., Gagnon, A. C., Adkins, J. F., 2011. An Isotope Dilution ICP-MS Method for the Determination of $\mathrm{Mg} / \mathrm{Ca}$ and $\mathrm{Sr} / \mathrm{Ca}$ Ratios in Calcium Carbonate. Geostandards and Geoanalytical Research 35 (1), 23-37. 
Foster, G. L., 2008. Seawater pH, pCO2 and [CO32-] variations in the Caribbean Sea over the last 130 kyr: A boron isotope and B/Ca study of planktic foraminifera. Earth and Planetary Science Letters 271 (1), 254-266.

Foster, G. L., Pogge von Strandmann, P. A. E., Rae, J. W. B., 2010. Boron and magnesium isotopic composition of seawater. Geochemistry, Geophysics, Geosystems 11 (8), Q08015.

Foster, L. C., Schmidt, D. N., Thomas, E., Arndt, S., Ridgwell, A., 2013. Surviving rapid climate change in the deep sea during the Paleogene hyperthermals. Proceedings of the National Academy of Sciences 110 (23), 9273-9276.

Gabitov, R. I., Gaetani, G. A., Watson, E. B., Cohen, A. L., Ehrlich, H. L., 2008. Experimental determination of growth rate effect on $\mathrm{U} 6+$ and $\mathrm{Mg} 2+$ partitioning between aragonite and fluid at elevated U6+ concentration. Geochimica et cosmochimica acta 72 (16), 4058-4068.

Gaetani, G. A., Cohen, A. L., 2006. Element partitioning during precipitation of aragonite from seawater: A framework for understanding paleoproxies. Geochimica et cosmochimica acta 70 (18), 4617-4634.

Gaetani, G. A., Cohen, A. L., Wang, Z., Crusius, J., 2011. Rayleigh-Based, MultiElement Coral Thermometry: a Biomineralization Approach to Developing Climate Proxies. Geochimica et cosmochimica acta 75, 1920-1932.

Gagan, M. K., Dunbar, G. B., Suzuki, A., 2012. The effect of skeletal mass accumulation in Porites on coral $\mathrm{Sr} / \mathrm{Ca}$ and $\delta 18 \mathrm{O}$ paleothermometry. Paleoceanography 27 (1), PA1203.

Gagnon, A. C., Adkins, J. F., Erez, J., 2012. Seawater transport during coral biomineralization. Earth and Planetary Science Letters 329, 150-161.

Gagnon, A. C., Adkins, J. F., Erez, J., Eiler, J. M., Guan, Y., 2013. Sr/Ca sensitivity to aragonite saturation state in cultured subsamples from a single colony of coral: Mechanism of biomineralization during ocean acidification. Geochimica et cosmochimica acta.

Giese, B. S., Ray, S., 2011. El Niño variability in simple ocean data assimilation (SODA), 1871-2008. Journal of Geophysical Research: Oceans (1978-2012) 116 (C2), C02024.

Grove, C. A., Kasper, S., Zinke, J., Pfeiffer, M., GarbeâĂ̌̌Schonberg, D., Brummer, G. A., 2013. Confounding effects of coral growth and high SST variability on skeletal Sr/Ca: implicatiaons for coral paleothermometry. Geochemistry, Geophysics, Geosystems 14 (4), 1277-1293.

Hathorne, E. C., Gagnon, A., Felis, T., Adkins, J., Asami, R., Boer, W., Caillon, N., Case, D., Cobb, K. M., Douville, E., DeMenocal, P., Eisenhauer, A., GarbeSchönberg, D., Geibert, W., Goldstein, S., Hughen, K., Inoue, M., Kawahata, H., 
Kölling, M., Cornec, F. L., Linsley, B. K., McGregor, H. V., Montagna, P., Nurhati, I. S., Quinn, T. M., Raddatz, J., Rebaubier, H., Robinson, L., Sadekov, A., Sherrell, R., Sinclair, D., Tudhope, A. W., Wei, G., Wong, H., Wu, H. C., You, C.-F., 2013. Interlaboratory study for coral $\mathrm{Sr} / \mathrm{Ca}$ and other element/Ca ratio measurements. Geochemistry, Geophysics, Geosystems 14 (9), 3730-3750.

Hendy, E. J., Gagan, M. K., Alibert, C. A., McCulloch, M. T., Lough, J. M., Isdale, P. J., 2002. Abrupt decrease in tropical Pacific sea surface salinity at end of Little Ice Age. Science 295 (5559), 1511-1514.

Henehan, M. J., Rae, J. W., Foster, G. L., Erez, J., Prentice, K. C., Kucera, M., Bostock, H. C., Martínez-Botí, M. A., Milton, J. A., Wilson, P. A., Marshall, B. J., Elliott, T., 2013. Calibration of the boron isotope proxy in the planktonic foraminifera Globigerinoides ruber for use in palaeo-CO2 reconstruction. Earth and Planetary Science Letters 364, 111-122.

Hereid, K. A., Quinn, T. M., Okumura, Y. M., 2013. Assessing spatial variability in El Niño-Southern Oscillation event detection skill using coral geochemistry. Paleoceanography.

Jones, J. P., Carricart-Ganivet, J. P., Iglesias Prieto, R., Enríquez, S., Ackerson, M., Gabitov, R. I., 2015. Microstructural variation in oxygen isotopes and elemental calcium ratios in the coral skeleton of Orbicella annularis. Chemical Geology 419, 192-199.

Karnauskas, K. B., Cohen, A. L., Drenkard, E. J., 2015. Comment on "Equatorial Pacific coral geochemical records show recent weakening of the Walker circulation" by J. Carilli et al. Paleoceanography 30 (5), 570-574.

Kinsman, D. J. J., Holland, H. D., 1969. The co-precipitation of cations with CaCO3IV. The co-precipitation of Sr2+ with aragonite between 16 and $96 \mathrm{C}$. Geochimica et cosmochimica acta 33 (1), 1-17.

Klochko, K., Kaufman, A. J., Yao, W., Byrne, R. H., Tossell, J. A., 2006. Experimental measurement of boron isotope fractionation in seawater. Earth and Planetary Science Letters 248 (1), 276-285.

Li, J., Sun, C., Jin, F., 2013. NAO implicated as a predictor of Northern Hemisphere mean temperature multidecadal variability. Geophysical Research Letters 40 (20), $5497-5502$.

Marshall, J. F., McCulloch, M. T., 2002. An assessment of the $\mathrm{Sr} / \mathrm{Ca}$ ratio in shallow water hermatypic corals as a proxy for sea surface temperature. Geochimica et cosmochimica acta 66 (18), 3263-3280.

Meehl, G. A., Teng, H., Arblaster, J. M., 2014. Climate model simulations of the observed early-2000s hiatus of global warming. Nature Climate Change 4 (10), 898-902. 
Meehl, G. A., Washington, W. M., Arblaster, J. M., Hu, A., Teng, H., Tebaldi, C., Sanderson, B. N., Lamarque, J.-F., Conley, A., Strand, W. G., White, J. B., 2012. Climate System Response to External Forcings and Climate Change Projections in CCSM4. Journal of Climate 25 (11), 3661-3683.

Nurhati, I. S., Cobb, K. M., Di Lorenzo, E., 2011. Decadal-scale SST and salinity variations in the central tropical Pacific: Signatures of natural and anthropogenic climate change. Journal of Climate 24 (13), 3294-3308.

Okai, T., Suzuki, A., Kawahata, H., Terashima, S., Imai, N., 2002. Preparation of a New Geological Survey of Japan Geochemical Reference Material: Coral JCp-1. Geostandards Newsletter 26 (1), 95-99.

Quinn, T. M., Sampson, D. E., 2002. A Multiproxy Approach to Reconstructing Sea Surface Conditions Using Coral Skeleton Geochemistry. Paleoceanography 17 (4), 1062.

Reynolds, R. W., Rayner, N. A., Smith, T. M., Stokes, D. C., Wang, W., 2002. An improved in situ and satellite SST analysis for climate. Journal of Climate 15 (13), 1609-1625.

Saenger, C., Cohen, A. L., Oppo, D. W., Hubbard, D., 2008. Interpreting sea surface temperature from strontium/calcium ratios in Montastrea corals: Link with growth rate and implications for proxy reconstructions. Paleoceanography 23 (3), PA3102.

Shamberger, K. E., Cohen, A. L., Golbuu, Y., McCorkle, D. C., Lentz, S. J., Barkley, H. C., 2014. Diverse coral communities in naturally acidified waters of a Western Pacific reef. Geophys. Res. Lett. 41 (2), 499-504.

Sinclair, D. J., Risk, M. J., 2006. A numerical model of trace-element coprecipitation in a physicochemical calcification system: Application to coral biomineralization and trace-element [] vital effects'. Geochimica et cosmochimica acta 70 (15), 38553868.

Smith, S. V., Buddemeier, R. W., Redalje, R. C., Houck, J. E., 1979. Strontiumcalcium thermometry in coral skeletons. Science 204 (4391), 404-7.

Smith, T. M., Reynolds, R. W., Peterson, T. C., Lawrimore, J., 2008. Improvements to NOAA's Historical Merged Land-Ocean Surface Temperature Analysis (18802006). Journal of Climate 21 (10), 2283-2296.

Solomon, A., Newman, M., 2012. Reconciling disparate twentieth-century Indo-Pacific ocean temperature trends in the instrumental record. Nature Climate Change 2 (9), 691-699.

Stevenson, S., Fox-Kemper, B., Jochum, M., Neale, R., Deser, C., Meehl, G., 2012. Will there be a significant change to El Niño in the twenty-first century? Journal of Climate 25 (6), 2129-2145. 
Stocker, T. F., Qin, D., Plattner, G. K., Tignor, M., Allen, S. K., Boschung, J., Nauels, A., Xia, Y., Bex, V., Midgley, P. M., 2013. IPCC, 2013: Summary for Policymakers. In Climate Change 2013: The Physical Science Basis. Tech. rep.

Storz, D., Gischler, E., Fiebig, J., Eisenhauer, A., Garbe-Schönberg, D., 2013. Evaluation of oxygen isotope and $\mathrm{Sr} / \mathrm{Ca}$ ratios from a Maldivian scleractinian coral for reconstruction of climate variability in the northwestern Indian Ocean. Palaios 28 (1), 42-55.

Sturgeon, R. E., Willie, S. N., Yang, L., Greenberg, R., Spatz, R. O., Chen, Z., Scriver, C., Clancy, V., Lam, J. W., Thorrold, S., 2005. Certification of a fish otolith reference material in support of quality assurance for trace element analysis. Journal of Analytical Atomic Spectrometry 20 (10), 1067-1071.

Tambutté, E., Tambutté, S., Segonds, N., Zoccola, D., Venn, A., Erez, J., Allemand, D., 2012. Calcein labelling and electrophysiology: insights on coral tissue permeability and calcification. Proceedings of the Royal Society B: Biological Sciences 279 (1726), 19-27.

Tanaka, K., Holcomb, M., Takahashi, A., Kurihara, H., Asami, R., Shinjo, R., Sowa, K., Rankenburg, K., Watanabe, T., McCulloch, M., 2015. Response of Acropora digitifera to ocean acidification: constraints from $\delta 11 \mathrm{~B}, \mathrm{Sr}, \mathrm{Mg}$, and $\mathrm{Ba}$ compositions of aragonitic skeletons cultured under variable seawater $\mathrm{pH}$. Coral Reefs 34 (4), 1139-1149.

Tierney, J. E., Abram, N. J., Anchukaitis, K. J., Evans, M. N., Giry, C., Kilbourne, K. H., Saenger, C. P., Wu, H. C., Zinke, J., 2015. Tropical sea surface temperatures for the past four centuries reconstructed from coral archives. Paleoceanography 30, $226-252$.

Toth, L. T., Aronson, R. B., Cobb, K. M., Cheng, H., Edwards, R. L., Grothe, P. R., Sayani, H. R., 2015. Climatic and biotic thresholds of coral-reef shutdown. Nature Climate Change 5, 369-374.

Venn, A., Tambutte, E., Holcomb, M., Allemand, D., Tambutte, S., 2011. Live tissue imaging shows reef corals elevate $\mathrm{pH}$ under their calcifying tissue relative to seawater. PLoS One 6 (5), e20013.

Weber, J. N., Woodhead, P. M. J., 1972. Temperature dependence of oxygen-18 concentration in reef coral carbonates. J. Geophys. Res. 77 (3), 463-473.

Wittenberg, A. T., 2009. Are historical records sufficient to constrain ENSO simulations? Geophysical Research Letters 36 (12).

Wu, H. C., Moreau, M., Linsley, B. K., Schrag, D. P., Corrège, T., 2014. Investigation of sea surface temperature changes from replicated coral $\mathrm{Sr} / \mathrm{Ca}$ variations in the eastern equatorial Pacific (Clipperton Atoll) since 1874. Palaeogeography, Palaeoclimatology, Palaeoecology 412, 208-222. 
Yoshinaga, J., Nakama, A., Morita, M., Edmonds, J. S., 2000. Fish otolith reference material for quality assurance of chemical analyses. Marine Chemistry 69 (1), 9197.

Zeebe, R. E., Wolf-Gladrow, D. A., 2001. CO2 in seawater: equilibrium, kinetics, isotopes. Vol. 65. Elsevier Science Limited. 


\section{Chapter 4}

\section{Coral bioerosion is accelerated by ocean acidification and nutrients}

\subsection{Abstract}

Coral reefs exist in a delicate balance between calcium carbonate $\left(\mathrm{CaCO}_{3}\right)$ production and $\mathrm{CaCO}_{3}$ loss. Ocean acidification (OA), the $\mathrm{CO}_{2}$-driven decline in seawater $\mathrm{pH}$ and $\mathrm{CaCO}_{3}$ saturation state $(\Omega)$, threatens to tip this balance by decreasing calcification, and increasing erosion and dissolution. While multiple $\mathrm{CO}_{2}$ manipulation experiments show coral calcification declines under OA, the sensitivity of bioerosion to $\mathrm{OA}$ is less well understood. Previous work suggests that coral and coral reef bioerosion increase with decreasing seawater $\Omega$. However, in the surface ocean, $\Omega$ and nutrient concentrations often covary, making their relative influence difficult to resolve. Here, we exploit unique natural gradients in $\Omega$ and nutrients across the Pacific basin to quantify the impact of these factors, together and independently, on macrobioerosion rates of coral skeletons. Using an automated program to quantify macrobioerosion in 3-D computerized tomography (CT) scans of coral cores, we show

DeCarlo T.M., Cohen A.L., Barkley H.C., Cobban Q., Young C., Shamberger K.E., Brainard R.E., Golbuu Y., 2015. Coral macrobioerosion is accelerated by ocean acidification and nutrients. Geology 43 (1), 7-10. 
that macrobioerosion rates of live Porites colonies in both low-nutrient (oligotrophic) and high-nutrient ( $>1 \mu \mathrm{M}$ nitrate) waters increase significantly as $\Omega$ decreases. However, the sensitivity of macrobioerosion to $\Omega$ is ten times greater under high-nutrient conditions. Our results demonstrate that OA (decreased $\Omega$ ) alone can increase coral macrobioerosion rates, but the interaction of OA with local stressors exacerbates its impact, accelerating a shift toward net $\mathrm{CaCO}_{3}$ removal from coral reefs.

\subsection{Introduction}

Tropical coral reefs are oases of productivity that support some of the world's most biologically diverse ecosystems and important fisheries. High productivity by sessile organisms on reefs requires formation of hard calcium carbonate $\left(\mathrm{CaCO}_{3}\right)$ substrate in the euphotic zone, where photosynthesis can occur. This is achieved through biogenic calcification by reef organisms such as corals, coralline algae, echinoids, foraminifera, and mollusks which, together with precipitation of abiogenic $\mathrm{CaCO}_{3}$, build and cement the reef framework. Coral reef frameworks are degraded through bioerosion, the biologically mediated breakdown and dissolution of $\mathrm{CaCO}_{3}$ skeletons, as well as natural dissolution and export of sand and rubble off the reef (Glynn, 1997). Today, net $\mathrm{CaCO}_{3}$ accretion typically exceeds, albeit barely, net erosion and dissolution, allowing reefs to remain near the sea surface (Stearn et al., 1977; Hubbard et al., 1990).

Of mounting concern is that ocean acidification (OA), the decrease in ocean $\mathrm{pH}$ caused by absorption of anthropogenic $\mathrm{CO}_{2}$, could shift this delicate balance toward a negative $\mathrm{CaCO}_{3}$ budget where $\mathrm{CaCO}_{3}$ loss exceeds $\mathrm{CaCO}_{3}$ production. Addition of $\mathrm{CO}_{2}$ to seawater decreases $\mathrm{pH}$ and lowers the $\mathrm{CaCO}_{3}$ saturation state $(\Omega)$, creating a less favorable environment for $\mathrm{CaCO}_{3}$ precipitation. Aragonite is the polymorph of $\mathrm{CaCO}_{3}$ that corals use to build skeletons and the $\mathrm{CaCO}_{3}$ saturation state with respect to aragonite $\left(\Omega_{\text {Arag }}\right)$ is therefore a useful quantity in identifying how OA impacts the reef $\mathrm{CaCO}_{3}$ budget. $\mathrm{CO}_{2}$ laboratory manipulation experiments show that as $\Omega_{\text {Arag }}$ decreases, rates of calcification by corals and coralline algae generally decline (Kroeker et al., 2010; Chan and Connolly, 2013). Additionally, laboratory $\mathrm{CO}_{2}$ 

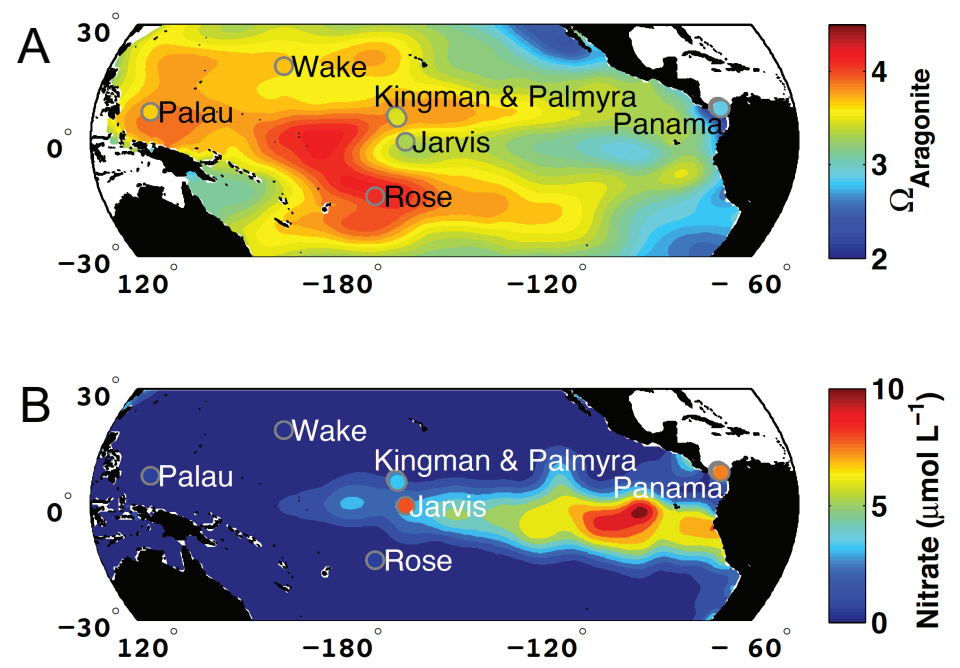

Figure 4-1: $\quad$ Study reef systems and climatological means of (A), aragonite saturation state $\left(\Omega_{\text {Arag }}\right)$ and (B), nitrate concentration in surface waters of the tropical Pacific Ocean.

manipulation experiments show that rates of bioerosion of coral skeleton increase with decreasing pH (Tribollet et al., 2009; Wisshak et al., 2012; Reyes-Nivia et al., 2013). The combination of declining calcification and increasing bioerosion under low $\mathrm{pH}$ and $\Omega_{\text {Arag }}$ implies that $\mathrm{OA}$ alone could drive coral reefs toward a state of net $\mathrm{CaCO}_{3}$ loss. However, the impact of OA on coral reef bioerosion has not been unequivocally demonstrated outside of the laboratory because in the tropical oceans, low $\Omega_{\text {Arag }}$ generally covaries with elevated nutrients, and high nutrient concentrations can drive high rates of coral bioerosion in the absence of acidification (Risk et al., 1995; Edinger et al., 2000; Holmes et al., 2000; Tribollet and Golubic, 2005).

We exploited natural gradients in $\Omega_{\text {Arag }}$ and nutrient concentrations across the Pacific basin to investigate the independent and interactive effects of ocean acidification and nutrients on macrobioerosion rates of live colonies of the Indo-Pacific coral Porites spp. While macrobioerosion ( $>1 \mathrm{~mm}$ boring diameter including bivalves, worms, and sponges) of coral skeleton is a fraction of total $\mathrm{CaCO}_{3}$ bioerosion on a reef (Glynn, 1997), independent studies show that macrobioerosion occurs in proportion to total bioerosion of coral rubble (Holmes et al., 2000) and experimental blocks of coral skeleton (Chazottes et al., 2002), and can thus be linked to total reef bioerosion. Macrobioerosion also affects the longevity of individual coral colonies, increasing their susceptibility to breakage and dislodgment by waves and storms (Scott and Risk, 1988; Chen et al., 2013). 


\subsection{Materials and Methods}

A total of 103 skeletal cores (3-7 cm diameter) were collected using underwater pneumatic/hydraulic drills from live Porites spp. coral colonies $(\sim 40-100 \mathrm{~cm}$ tall $)$ that appeared visually healthy at 11 sampling locations within 7 reef systems across the Pacific basin (Fig. 4-1; Table 4.1). Cores were drilled downwards along the axis of maximum growth from approximately the center of the colonies, to an average depth of $\sim 35 \mathrm{~cm}$. Across the Pacific basin, strong natural gradients exist in $\Omega_{\text {Arag }}$ and nutrient concentrations (Fig. 4-1), and in general, this pattern is supported by in situ sampling of the carbonate chemistry and dissolved inorganic nutrients of reef seawater (Table 3.1). Two eastern Pacific reefs (Pearl Islands and Taboga) in the Gulf of Panama are exposed to local upwelling water of low $\Omega_{\text {Arag }}$ and high nutrient concentrations (D'Croz and O'Dea, 2007; Manzello et al., 2008). In the central Pacific, Jarvis Island, Palmyra Atoll, and Kingman Reef are located near the margin of the Pacific cold-tongue, where wind-driven upwelling along the Equator brings water to the surface that is relatively acidic and nutrient-rich compared to surrounding water. Rose Atoll and Wake Atoll are not exposed to cold-tongue waters and are characterized by high $\Omega_{A r a g}$, low nutrient conditions. On Palau, in the tropical western Pacific, a strong natural gradient in $\Omega_{\text {Arag }}$ exists across the archipelago, at persistently low nutrient concentrations (Table 4.1) (Shamberger et al., 2014). This

reef system provides a unique opportunity to investigate the effect of low $\Omega_{\text {Arag }}$ on coral macrobioerosion in the absence of the confounding effect of elevated nutrients.

To characterize $\Omega_{\text {Arag }}$ and nutrient concentrations in reef seawater, samples were collected during multiple years, seasons, and times of day at the majority of our eleven reef locations (Table 4.1). Nevertheless, some degree of uncertainty remains because accurate estimates of the average $\Omega_{\text {Arag }}$ and nutritional environment over the lifetime of the coral requires sampling on all relevant timescales, including diurnal, seasonal, inter-annual and decadal. Comparison with other in situ datasets suggests that this uncertainty is small relative to the range captured by our study sites (details provided in the Supplementary Information). 


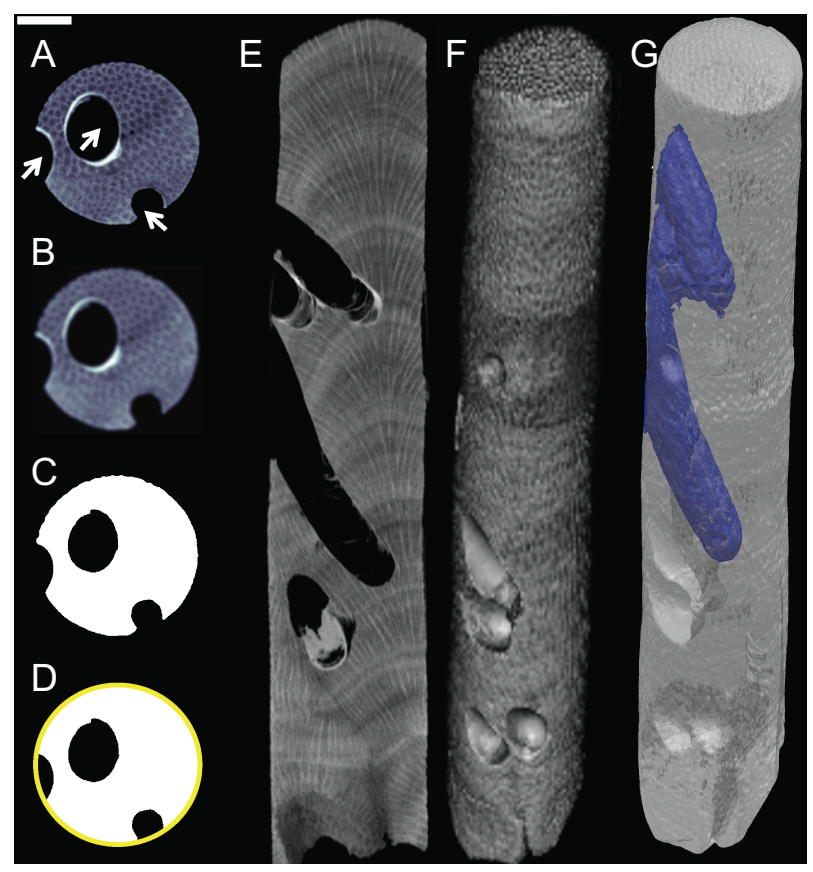

Figure 4-2: Macrobioerosion (by lithophagid bivalves in this particular core) in a CT scan of a Porites skeleton core from Panama. (A-D), axial cross-sections showing measurement of \% volume bioeroded. (A), Density variability (relatively light shading indicates high density) shows $\sim 200$ individual corallites (dark spots) and three borings (arrows). The image in (A) was filtered to reduce density variability of corallites in (B), converted to binary (coral / surrounding air) in (C), and fit with an ellipse to identify area of borings (black regions within yellow circle) in (D). (E), Sagittal cross-section showing annual density banding and borings. (F), Surface rendering showing outside of the core. (G), translucent surface showing borings in the center of the core (blue) that are visible in the cross-section in (E) but not in the outside surface of (F). Scale bar in upper left is $1 \mathrm{~cm}$.

We developed an automated computer program to quantify calcification and macrobioerosion rates in coral skeleton cores scanned by computerized tomography (CT). The program quantifies coral extension rate following the methods of Cantin et al. (2010), with modification to automatically trace the 3-dimensional growth paths of individual corallites within the core. This enables growth information to be collected from the entire 3-D core. Bulk skeletal density was determined from CT scans by comparison to coral standards, cylinders of coral skeleton whose density is calculated from mass and volume. Annual coral calcification rate $\left(\mathrm{g} \mathrm{cm}^{-2} \mathrm{yr}^{-1}\right)$ was calculated as the product of skeletal density $\left(\mathrm{g} \mathrm{cm}^{-3}\right)$ and extension rate $\left(\mathrm{cm} \mathrm{yr}^{-1}\right)$. The automated program is described in detail in the Supplementary Information. We define "bioerosion rate" as the average rate at which $\mathrm{CaCO} 3$ is removed from the colony over the timespan represented by the core:

bioerosion rate $\left(\mathrm{g} \mathrm{CaCO}_{3} \mathrm{~cm}^{-2}\right.$ year $\left.^{-1}\right)=\frac{\text { (volume bioeroded })(\text { skeletal density })}{(\text { coral surface area })(\text { core timespan })}$ 
Equation 4.1 is equivalent to the product of $\%$ volume bioeroded (Fig. 4-2) and coral calcification rate. Converting \% volume bioeroded to a mean bioerosion rate corrects potential biases caused by differences in growth rates and density amongst corals.

The $\%$ volume bioeroded data were fit with $\Omega_{\text {Arag }}$ as the predictor variable using a generalized additive model for location, scale, and shape with a beta zero-inflated distribution (GAMLSS-BID) (Rigby and Stasinopoulos, 2005). GAMLSS allows both the mean \% volume bioeroded and the skewness toward zero values (i.e. cores without macrobioerosion) to depend on $\Omega_{\text {Arag }}$ and nutrients. Sensitivity of macrobioerosion to $\Omega_{\text {Arag }}$ between low- ( $<1 \mu \mathrm{M}$ nitrate) and high- ( $>1 \mu \mathrm{M}$ nitrate) nutrient reefs was evaluated by comparing slopes of ordinary least squares regressions fit to the reef mean macrobioerosion rates. Heteroscedasticity of the data precluded significance tests using linear regression, but did not invalidate the regression coefficients.

\subsection{Results and Discussion}

Using only those cores collected from low-nutrient reefs spanning a natural gradient in $\Omega_{\text {Arag }}$ we first quantified the impact of ocean acidification on macrobioerosion without the confounding influence of nutrients (Fig. 4-3). Our results show a significant ( $\mathrm{p}<$ $0.05)$ increase in macrobioerosion with decreasing seawater $\Omega_{\text {Arag }}$. This result confirms that ocean acidification alone increases rates of coral macrobioerosion, consistent with laboratory experiments that show increased sponge (Wisshak et al., 2012) and micro(Tribollet et al., 2009; Reyes-Nivia et al., 2013) bioerosion of coral skeleton under simulated $\mathrm{OA} /$ low-nutrient conditions. In our corals, macrobioerosion rates increase by $10 \mathrm{mg} \mathrm{CaCO}_{3} \mathrm{~cm}^{-2} \mathrm{yr}^{-1}$ per unit decrease of $\Omega_{\text {Arag }}$. Other field studies have reported high rates of bioerosion where seawater $\Omega_{\text {Arag }}$ is relatively low. For example, in the eastern tropical Pacific, high bioerosion rates (Reaka-Kudla et al., 1996) were measured on coral reefs bathed with naturally low $\Omega_{\text {Arag }}$ upwelled water (Manzello et al., 2008). Similarly, the density of macrobioeroders observed at the surface of live Porites colonies increased along a natural acidification gradient caused by $\mathrm{CO}_{2}$ venting onto reefs in Papua New Guinea (Fabricius et al., 2011). Low-pH seawater caused 


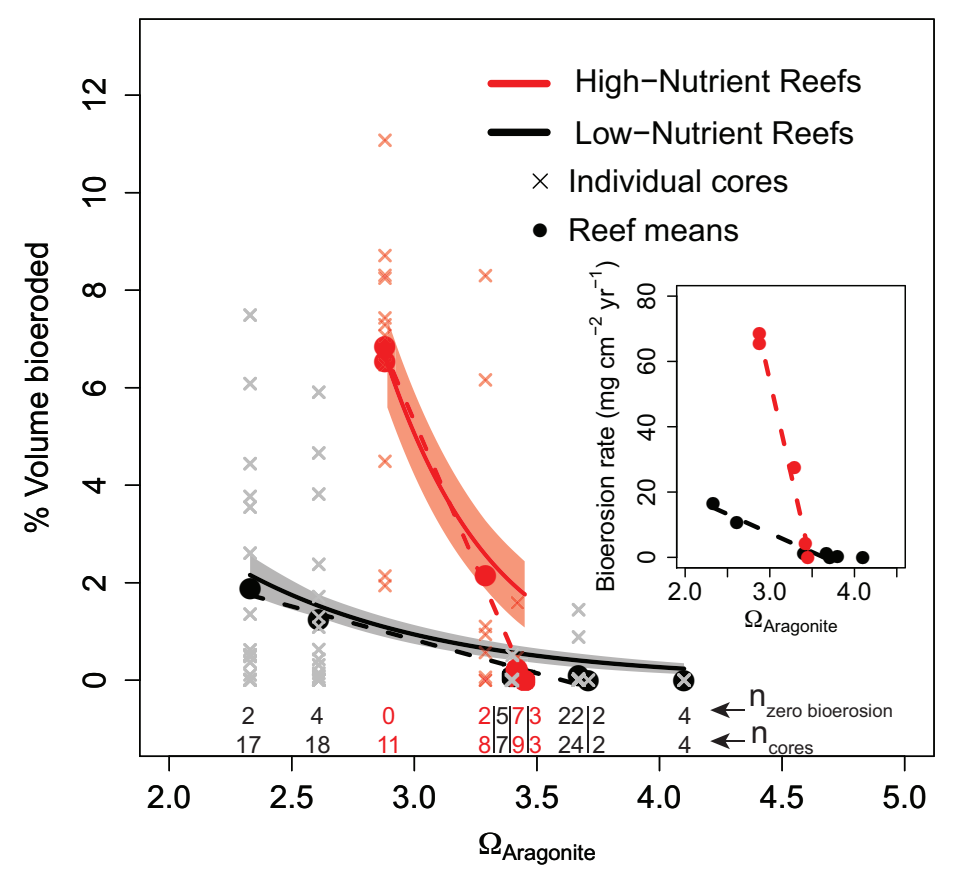

Figure 4-3: Relationship between macrobioerosion in the skeletons of living Porites colonies and aragonite saturation state $\left(\Omega_{\text {Arag }}\right)$ for low-nutrient (black) and high-nutrient (red) reefs (solid lines are model fits; shading is standard error). Reef mean macrobioerosion indicated with circles and linear fits with dashed lines. The inset shows reef mean macrobioerosion rate.

by submarine discharge was also linked to higher incidence of bioerosion in Porites astreoides colonies in the Yucatan (Crook et al., 2013). In these studies however, low $\mathrm{pH}$ and low $\Omega_{\text {Arag }}$ either covary with high nutrient concentrations (Manzello et al., 2008; Crook et al., 2013), or nutrient data were not reported (Fabricius et al., 2011), making it difficult to attribute increased bioerosion or bioeroder density solely to OA.

Using a second set of cores, collected from high-nutrient reefs spanning a natural gradient in $\Omega_{\text {Arag }}$, we investigated the combined impact of ocean acidification and elevated nutrients on coral macrobioerosion rates (Fig. 4-3). Our results show that sensitivity of macrobioerosion rate to $\Omega_{\text {Arag }}$ increases by an order of magnitude - from 10 to $110 \mathrm{mg} \mathrm{CaCO} \mathrm{cm}^{-2} \mathrm{yr}^{-1}$ per unit decrease of $\Omega_{\text {Arag }}$ - from low-nutrient reefs to high-nutrient reefs. The GAMLSS-BID analysis showed a significant effect of $\Omega_{\text {Arag }}$ on macrobioerosion within high-nutrient reefs, and a significant effect of nutrients when all reefs were included with $\Omega_{\text {Arag }}$ as a continuous predictor and nutrients as a categorical predictor. Our observation that nutrients accelerate coral bioerosion rates is consistent with that reported for live corals (Sammarco and Risk, 1990; Risk et al., 1995; Edinger et al., 2000; Holmes et al., 2000; Chen et al., 2013), coral rubble (Holmes 
et al., 2000), and experimental blocks of coral skeleton exposed on high-nutrient reefs (Chazottes et al., 2002; Tribollet and Golubic, 2005).

There are several potential mechanisms for coral macrobioerosion rates to increase with decreasing $\Omega_{\text {Arag }}$ and with increasing nutrients. First, relatively acidic seawater may increase the efficiency with which coral skeleton is dissolved by bioeroding organisms. For example, boring algae that infest live coral colonies, and increase their susceptibility to macrobioerosion, drive dissolution along the most soluble crystal surfaces (Kobluk and Risk, 1977). Second, the skeletons in relatively low $\Omega_{\text {Arag }}$ may be more soluble than those formed in higher $\Omega_{\text {Arag }}$ waters. However, the role of coral skeletal density in determining sensitivity to macrobioerosion has been considered previously, with mixed results (Highsmith, 1981; Sammarco and Risk, 1990), and we found no significant effect of skeletal density on macrobioerosion in the GAMLSSBID analyses. Nor did we find a relationship to water depth or reef type (Table 4.1). Third, nutrient enrichment may stimulate primary productivity, elevating particulate food availability and turbidity, making nutrient-rich reefs favorable environments for filter-feeding bioeroders. Thus, it is possible that productivity or the concentration of particulate organic matter, rather than nitrate concentration, is the variable directly affecting bioerosion rates. If this is the case, more of the variance in bioerosion rates may be attributable to food availability than nitrate concentration because the standing stock of nutrients does not necessarily represent the rate of productivity or the amount of particulate organic matter in the water column. In the semi-isolated bays of Palau, for instance, it is possible that bioeroders benefit from local production that maintains consistently low nitrate concentrations but provides particulate food for filter-feeding bioeroders, and that the relatively low $\Omega_{\text {Arag }}$ of these waters has a less important influence on bioerosion than suggested by our results based on $\mathrm{CO}_{2}$ chemistry and nitrate concentrations alone.

Bioerosion is a natural process on coral reefs that supplies carbonate sediments critical to the cementation of the reef (Glynn, 1997), and may contribute to propagation of certain coral species that reproduce by fragmentation (Tunnicliffe, 1981). However, calcification must exceed bioerosion in order for reefs to grow and persist 
in the euphotic zone. Ocean acidification will drive a decrease in rates of calcification by corals and coralline algae, and ocean warming will exacerbate these impacts by inducing coral bleaching and mortality (Hoegh-Guldberg et al., 2007). If decreased calcification co-occurs with increased bioerosion, the $\mathrm{CaCO}_{3}$ balance will shift more rapidly toward a negative $\mathrm{CaCO}_{3}$ budget.

\subsection{Conclusions}

The results of this study show that the combination of OA (low $\Omega_{\text {Arag }}$ ) and nutrient loading is ten times more effective at driving coral macrobioerosion than OA alone. Over the next century, $\Omega_{\text {Arag }}$ of reef seawater will be governed by the ocean's absorption of anthropogenic $\mathrm{CO}_{2}$, and local and regional variability in biogeochemical processes (e.g., net photosynthesis and net calcification). However, anthropogenic nutrient loading is already a major threat to coral reef ecosystems, with at least one quarter of coral reefs impacted by coastal development and watershed pollution (Burke et al., 2011). Curtailing global $\mathrm{CO}_{2}$ emissions, the primary driver of ocean acidification, cannot be tackled at a local level. However, effective local management strategies can limit anthropogenic nutrient fluxes to coral reefs, and are urgently needed to slow the shift to net $\mathrm{CaCO}_{3}$ removal for corals, and potentially coral reef ecosystems, worldwide.

\subsection{Supplementary Information}

\subsubsection{Details of Carbonate System Chemistry Measurements}

Mean $\Omega_{\text {Arag }}$ in the Gulf of Panama was calculated previously from in situ seawater samples collected during the day and night during one wet and one dry season (Manzello et al., 2008; Manzello, 2010). Seawater samples from the following sites were analyzed for both alkalinity/DIC and dissolved inorganic nutrients. On Jarvis, Kingman and Palmyra, seawater samples were collected over the course of the day (9 AM to 5 PM), over multiple years $(2006,2008,2010)$, primarily in springtime 
(March-May). Our Jarvis data include additional Fall samples (September, 2012). To assess the representativeness of our samples of average conditions, we compared $\mathrm{pH}$ calculated from alkalinity and DIC analyses with $\mathrm{pH}$ data reported by Price et al. (2012), who deployed automated, in situ SeaFet pH sensors on the same reefs over diurnal and seasonal cycles (Table DR1). Our values are within error of the Price et al. (2012) values for each reef.

On Rose Atoll, seawater samples were collected in springtime of 2006, 2008, 2010, and 2012. Mean $\Omega_{\text {Arag }}$ (4.10) calculated from in situ alkalinity and DIC is consistent with the climatology (4.19) calculated from GLODAP/World Ocean Atlas. 6 out of 103 cores were collected from Rose Atoll and Wake Atoll. Any uncertainty in our average $\Omega_{\text {Arag }}$ estimate has a small influence on our statistical model, and our significance tests and our conclusions would remain the same if data from Rose Atoll and Wake Atoll were excluded.

Within Palau, $\Omega_{\text {Arag }}$ at each sampling site was calculated from alkalinity/DIC analyses of seawater samples collected from 6 AM to 6 PM over multiple tidal cycles, seasons and years. These data are reported in Shamberger et al. (2014). To assess the representativeness of our daytime samples of the average diurnal $\Omega_{\text {Arag }}$, we compared our Palau $\Omega_{\text {Arag }}$ values with data recently generated from seawater samples collected every two hours for 4 consecutive days in November 2013 on both a low-pH reef and a barrier (ambient $\mathrm{pH}$ ) reef. Daytime $\Omega_{\text {Arag }}$ was not significantly different from nighttime $\Omega_{\text {Arag }}$ over this sampling period (Table DR2; K.E. Shamberger 2014 unpublished data), and our values are within error. This suggests that sampling from dawn to dusk does not bias our estimates of the mean $\Omega_{\text {Arag }}$ of our Palau sample sites.

\subsubsection{Computerized Tomography (CT) Scans}

A Siemens Volume Zoom Spiral computerized tomography (CT) scanner at Woods Hole Oceanographic Institution was used to image the cores following the methods

described in Saenger et al. (2009); Cantin et al. (2010); Crook et al. (2013). The standard curve used to convert CT scan x-ray attenuation to density was constructed 
from nine, 3-cm diameter, dried Porites cores (Fig. DR1). Absolute bulk skeletal density of each standard, ranging from $0.809-1.537 \mathrm{~g} \mathrm{~cm}^{-3}$, was calculated as the quotient of measured core mass and volume.

\subsubsection{Automated Analysis of CT Scan Data to Quantify Coral Skeletal Parameters (Extension, Density, Calcification)}

Calcification rate $\left(\mathrm{g} \mathrm{cm}^{-2} \mathrm{yr}^{-1}\right)$ was calculated as the product of extension of the coral colony surface during one year $\left(\mathrm{cm} \mathrm{yr}^{-1}\right)$ and density of skeleton over the year's extension $\left(\mathrm{g} \mathrm{cm}^{-3}\right)$ (Barnes and Lough 1993).

Corallites were identified in each image by finding local density minima, which are the porous centers of calices surrounded by dense thecal walls. Images were first filtered with a 2-dimensional Gaussian filter (standard deviation $0.29 \mathrm{~mm}$ and clipped at $0.97 \mathrm{~mm}$ ), which resulted in one local density minima per corallite (Fig. DR2). A Euclidian-distance nearest neighbors approach was used to assign each voxel within the core to the nearest corallite. The mean density of all voxels in one image assigned to a given corallite was taken as the corallite density in that image. Corallites were connected throughout the core by finding the nearest corallites in consecutive images.

Annual density bands were identified by visual inspection of slabs digitally cut along the vertical growth axis of the cores (Fig. DR2). Local density minima (annual bands) were identified in several locations in each slab and repeated in 4 slabs throughout the core. Low-density bands were mapped in 3-dimensions by interpolating between the coordinates where the bands were marked.

Corallite density tracks were used to objectively define the locations of annual density bands. For each identified band, all corallites passing through the band were searched for local density minima within $1 \mathrm{~mm}$ of the identified band location. If a density minimum was found, the annual band at the location of the given corallite was shifted to match the density minimum. After making adjustments for all corallites passing through a band, the new coordinates of the band were interpolated to map the band in 3 dimensions. Bands were smoothed by a 2-dimensional Gaussian filter 
(standard deviation $0.97 \mathrm{~mm}$ and clipped at $0.97 \mathrm{~mm}$ ).

For each year's growth (region between 2 low-density bands), all corallites were identified that extended in the core throughout the full year. A vector was fit to the 3dimensional coordinates every $2 \mathrm{~mm}$ of vertical growth with the origin set to the first corallite coordinate, the vector direction determined by singular value decomposition and the magnitude (length) determined by Euclidian distance. The sum of lengths of all vectors fit on a corallite's path between annual bands was taken as the annual extension rate of that corallite. Calcification rate was determined for each corallite as the product of annual extension and density, and all corallite calcification rates were averaged to determine the annual whole-core calcification rate. All image analyses were conducted with MATLAB 2012a.

TABLE DR1. PH MEASURED ON CENTRAL PACIFIC REEFS

\begin{tabular}{lcc}
\hline \hline Reef Site & Our pH & Price et al. (2012) $\mathrm{pH}$ \\
\hline Jarvis Island & $7.98 \pm 0.02$ & $8.005 \pm 0.013$ \\
Palmyra Atoll S forereef & $8.007 \pm 0.011$ & $7.995 \pm 0.012$ \\
Kingman Reef & $8.004 \pm 0.012$ & $8.025 \pm 0.009$ \\
\hline
\end{tabular}

TABLE DR2. DIURNAL VARIABILITY OF ARAGONITE SATURATION STATE $(\Omega)$ IN PALAU

\begin{tabular}{lccc}
\hline \hline Reef Site & Daytime $\Omega \pm 1 \sigma$ & Nighttime $\Omega \pm 1 \sigma$ & Average Diurnal $\Omega \pm 1 \sigma$ \\
\hline Low pH bay reef & $2.77 \pm 0.05$ & $2.74 \pm 0.20$ & $2.75 \pm 0.22$ \\
Barrier reef & $3.72 \pm 0.27$ & $3.57 \pm 0.27$ & $3.66 \pm 0.28$ \\
\hline
\end{tabular}

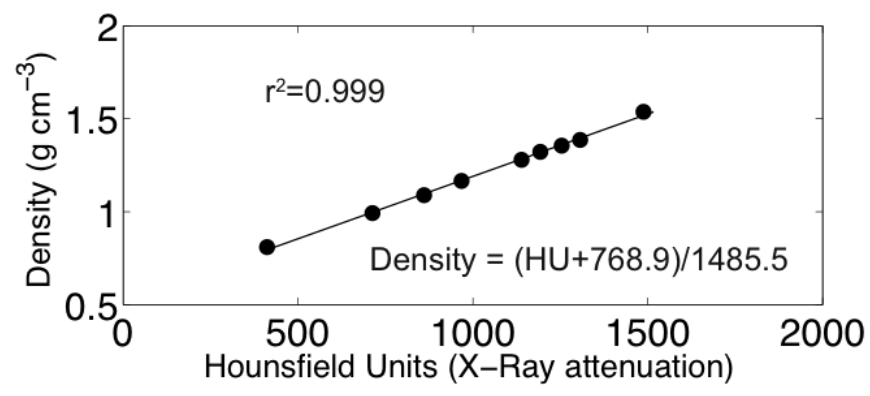

Figure DR1. Standard curve used to convert CT attenuation (Hounsfield Units) to bulk coral skeletal density $\left(\mathrm{g} \mathrm{cm}^{-3}\right)$. 


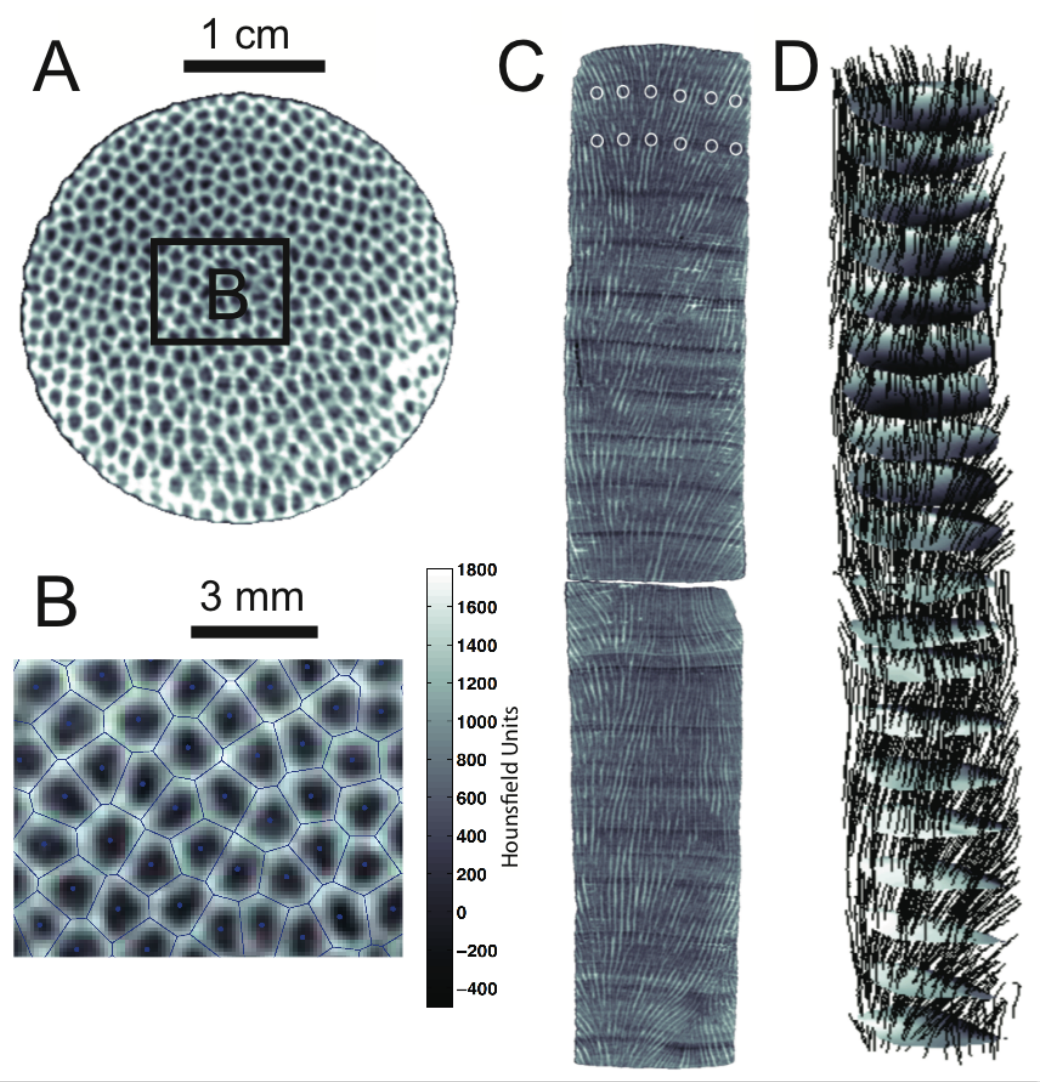

Figure DR2. Calcification rate analysis in a CT scan of a Porites core. (A), Axial cross-section of the core showing corallites (dark regions, low density) surrounded by skeletal walls (white, high density). (B), Blue dots show the identification of corallites by finding local density minima. Blue lines show a Voronoi diagram drawn around the corallites. (C), A slab digitally cut in the sagittal plane. Near-vertical light and dark streaks are paths of individual corallites through the core. Horizontal dark (low density) bands were interpreted as indicating annual growth. The first two low-density bands have been identified in the figure, as indicated by the white circles. (D), A 3-dimensional reconstruction of annual banding and corallite paths. Horizontal sheets are the mapped and interpolated annual low-density bands, and have been shaded to aid visualization of 3-dimensional shape. Black lines indicate paths of individual corallites traced through the core. For clarity, the image is viewed from an oblique angle looking slightly downward, and only $20 \%$ of all corallite paths are plotted. Scale bar is $1 \mathrm{~cm}$ and the core is $30 \mathrm{~cm}$ in height. 


\section{Bibliography}

Burke, L. M., Reytar, K., Spalding, M., Perry, A., 2011. Reefs at risk revisited. World Resources Institute Washington, DC.

Cantin, N. E., Cohen, A. L., Karnauskas, K. B., Tarrant, A. M., McCorkle, D. C., 2010. Ocean warming slows coral growth in the central Red Sea. Science 329 (5989), 322.

Chan, N. C. S., Connolly, S. R., 2013. Sensitivity of coral calcification to ocean acidification: a meta-analysis. Global Change Biology 19 (1), 282-290.

Chazottes, V., Le Campion-Alsumard, T., Peyrot-Clausade, M., Cuet, P., 2002. The effects of eutrophication-related alterations to coral reef communities on agents and rates of bioerosion (Reunion Island, Indian Ocean). Coral Reefs 21 (4), 375-390.

Chen, T., Li, S., Yu, K., Zheng, Z., Wang, L., Chen, T., 2013. Increasing temperature anomalies reduce coral growth in the Weizhou Island, northern South China Sea. Estuarine, Coastal and Shelf Science.

Crook, E. D., Cohen, A. L., Rebolledo-Vieyra, M., Hernandez, L., Paytan, A., 2013. Reduced calcification and lack of acclimatization by coral colonies growing in areas of persistent natural acidification. Proceedings of the National Academy of Sciences.

D'Croz, L., O'Dea, A., 2007. Variability in upwelling along the Pacific shelf of Panama and implications for the distribution of nutrients and chlorophyll. Estuarine, Coastal and Shelf Science 73 (1), 325-340.

Edinger, E. N., Limmon, G. V., Jompa, J., Widjatmoko, W., Heikoop, J. M., Risk, M. J., 2000. Normal coral growth rates on dying reefs: are coral growth rates good indicators of reef health? Marine Pollution Bulletin 40 (5), 404-425.

Fabricius, K. E., Langdon, C., Uthicke, S., Humphrey, C., Noonan, S., De'ath, G., Okazaki, R., Muehllehner, N., Glas, M. S., Lough, J. M., 2011. Losers and winners in coral reefs acclimatized to elevated carbon dioxide concentrations. Nature Climate Change 1 (3), 165-169.

Glynn, P. W., 1997. Bioerosion and coral-reef growth: a dynamic balance. Life and death of coral reefs, 68-95.

Highsmith, R. C., 1981. Coral bioerosion at Enewetak: agents and dynamics. Internationale Revue der Gesamten Hydrobiologie und Hydrographie 66 (3), 335-375.

Hoegh-Guldberg, O., Mumby, P. J., Hooten, A. J., Steneck, R. S., Greenfield, P., Gomez, E., Harvell, C. D., Sale, P. F., Edwards, A. J., Caldeira, K., 2007. Coral reefs under rapid climate change and ocean acidification. Science 318 (5857), 17371742 . 
Holmes, K. E., Edinger, E. N., Limmon, G. V., Risk, M. J., 2000. Bioerosion of live massive corals and branching coral rubble on Indonesian coral reefs. Marine Pollution Bulletin 40 (7), 606-617.

Hubbard, D. K., Miller, A. I., Scaturo, D., 1990. Production and cycling of calcium carbonate in a shelf-edge reef system (St. Croix, US Virgin Islands): applications to the nature of reef systems in the fossil record. Journal of Sedimentary Research $60(3)$.

Kobluk, D. R., Risk, M. J., 1977. Rate and nature of infestation of a carbonate substratum by a boring alga. Journal of experimental marine biology and ecology 27 (2), 107-115.

Kroeker, K. J., Kordas, R. L., Crim, R. N., Singh, G. G., 2010. Meta-analysis reveals negative yet variable effects of ocean acidification on marine organisms. Ecology letters 13 (11), 1419-1434.

Manzello, D. P., 2010. Coral growth with thermal stress and ocean acidification: lessons from the eastern tropical Pacific. Coral Reefs 29 (3), 749-758.

Manzello, D. P., Kleypas, J. A., Budd, D. A., Eakin, C. M., Glynn, P. W., Langdon, C., 2008. Poorly cemented coral reefs of the eastern tropical Pacific: Possible insights into reef development in a high-CO2 world. Proceedings of the National Academy of Sciences 105 (30), 10450.

Price, N. N., Martz, T. R., Brainard, R. E., Smith, J. E., 2012. Diel variability in seawater $\mathrm{pH}$ relates to calcification and benthic community structure on coral reefs. PLoS One 7 (8), e43843.

Reaka-Kudla, M. L., Feingold, J. S., Glynn, W., 1996. Experimental studies of rapid bioerosion of coral reefs in the Galapagos Islands. Coral Reefs 15 (2), 101-107.

Reyes-Nivia, C., Diaz-Pulido, G., Kline, D., Guldberg, O., Dove, S., 2013. Ocean acidification and warming scenarios increase microbioerosion of coral skeletons. Global Change Biology.

Rigby, R. A., Stasinopoulos, D. M., 2005. Generalized additive models for location, scale and shape. Journal of the Royal Statistical Society: Series C (Applied Statistics) $54(3), 507-554$.

Risk, M. J., Sammarco, P. W., Edinger, E. N., 1995. Bioerosion in Acropora across the continental shelf of the Great Barrier Reef. Coral Reefs 14 (2), 79-86.

Saenger, C., Cohen, A. L., Oppo, D. W., Halley, R. B., Carilli, J. E., 2009. Surfacetemperature trends and variability in the low-latitude North Atlantic since 1552. Nature Geoscience 2 (7), 492-495. 
Sammarco, P. P. W., Risk, M. M. J., 1990. Large-scale patterns in internal bioerosion of Porites: cross continental shelf trends on the GBR. Marine Ecology Progress Series-pages: 59: 145-156.

Scott, P. J. B., Risk, M. J., 1988. The effect of Lithophaga (Bivalvia: Mytilidae) boreholes on the strength of the coral Porites lobata. Coral Reefs 7 (3), 145-151.

Shamberger, K. E., Cohen, A. L., Golbuu, Y., McCorkle, D. C., Lentz, S. J., Barkley, H. C., 2014. Diverse coral communities in naturally acidified waters of a Western Pacific reef. Geophys. Res. Lett. 41 (2), 499-504.

Stearn, C. W., Scoffin, T. P., Martindale, W., 1977. Calcium Carbonate Budget of a Fringing Reef on the West Coast of Barbados Part I-Zonation and Productivity. Bulletin of Marine Science 27 (3), 479-510.

Tribollet, A., Godinot, C., Atkinson, M., Langdon, C., 2009. Effects of elevated pCO2 on dissolution of coral carbonates by microbial euendoliths. Global Biogeochemical Cycles 23 (3), GB3008.

Tribollet, A., Golubic, S., 2005. Cross-shelf differences in the pattern and pace of bioerosion of experimental carbonate substrates exposed for 3 years on the northern Great Barrier Reef, Australia. Coral Reefs 24 (3), 422-434.

Tunnicliffe, V., 1981. Breakage and propagation of the stony coral Acropora cervicornis. Proceedings of the National Academy of Sciences 78 (4), 2427-2431.

Wisshak, M., Schönberg, C. H. L., Form, A., Freiwald, A., 2012. Ocean Acidification Accelerates Reef Bioerosion. PLoS One 7 (9), e45124. 


\section{Chapter 5}

\section{Community production modulates}

\section{coral reef $\mathrm{pH}$ and the sensitivity of}

ecosystem calcification to ocean

\section{acidification}

\subsection{Abstract}

Coral reefs are built of calcium carbonate $\left(\mathrm{CaCO}_{3}\right)$ produced biogenically by a diversity of calcifying plants, animals and microbes. As the oceans warm and acidify, there is mounting concern that declining rates of calcification could shift coral reef $\mathrm{CaCO}_{3}$ budgets from net accretion to net dissolution. We quantified net ecosystem calcification (NEC) and production (NEP) on Dongsha Atoll, northern South China Sea, over a two-week period that included a transient bleaching event. Peak daytime $\mathrm{pH}$ on the wide, shallow reef flat during the non-bleaching period was 8.5, significantly elevated above that of the surrounding open ocean (8.0-8.1) as a consequence

DeCarlo T.M., Cohen A.L., Wong G.T.F., Shiah F.-K., Lentz S.J., Davis K.A., Shamberger K.E.F., Lohmann P. (submitted). Community production modulates coral reef $\mathrm{pH}$ and the sensitivity of ecosystem calcification to ocean acidification. Journal of Geophysical Research - Oceans 
of high daytime NEP (up to $120 \mathrm{mmol} \mathrm{C} \mathrm{m}^{-2} \mathrm{hr}^{-1}$ ). Diurnal averaged NEC was 390 $\pm 90 \mathrm{mmol} \mathrm{CaCO}_{3} \mathrm{~m}^{-2}$ day $^{-1}$, higher than any other coral reef studied to date despite comparable calcifier cover (25\%) and relatively high fleshy algal cover (19\%). A transient coral bleaching event linked to elevated temperatures significantly reduced daytime NEP by $31 \mathrm{mmol} \mathrm{C} \mathrm{m}{ }^{-2} \mathrm{hr}^{-1}$. $\mathrm{pH}$ on the reef flat declined by 0.2 units, causing a $40 \%$ reduction in NEC in the absence of any changes in the $\mathrm{pH}$ of the surrounding open ocean. Our findings highlight the interactive relationship between the carbonate system chemistry of coral reef ecosystems and rates of ecosystem production and calcification, which are in turn impacted by ocean warming. As the open ocean surrounding coral reefs warms and acidifies over the 21st century, the health and composition of the reef benthic community will play a major role in determining on-reef conditions that will in turn dictate the ecosystem response to climate change.

\subsection{Introduction}

Coral reef ecosystems feed millions of people worldwide, provide shoreline protection, and generate trillions of dollars annually in tourism revenue (Costanza et al., 2014). Yet coral reefs are threatened by the rapid acidification of the oceans. Since the start of the industrial era, atmospheric $\mathrm{CO}_{2}$ concentrations have increased at rates unprecedented for hundreds of millions of years (Hönisch et al., 2012; Zeebe et al., 2016), and one quarter of anthropogenic $\mathrm{CO}_{2}$ emissions have already been absorbed into the oceans (Sabine et al., 2004), driving down ocean $\mathrm{pH}$ and $\Omega_{\text {Arag }}$, a process known as ocean acidification (Doney et al., 2009). Multiple studies have investigated coral reef calcification (net ecosystem calcification, or NEC) with techniques ranging from flow respirometry to inventories of species present and their individual calcification rates (Odum and Odum, 1955; Kinsey, 1985). These studies consistently report correlations between NEC and reef-water $\Omega_{\text {Arag }}$, and these relationships are used to forecast when ocean acidification will shift reefs from net accretion to net dissolution (Ohde and van Woesik, 1999; Shamberger et al., 2011; Shaw et al., 2012; Bernstein et al., 2016; Muehllehner et al., 2016). Multi-decade declines of NEC have already 
been observed on the Great Barrier Reef and attributed primarily to ocean acidification (Silverman et al., 2012, 2014). Supporting this assertion, Albright et al. (2016) artificially manipulated reef-water $\mathrm{pH}$ to levels of the pre-industrial open ocean, and found that NEC increased. If these results are representative of coral reefs worldwide they imply that ocean acidification has already decreased NEC rates, and they raise concerns that this trend will endure into the next century as open-ocean $\mathrm{pH}$ continues to decline.

Such concerns are rooted in the assumption that reef-water $\mathrm{pH}$ tracks open-ocean $\mathrm{pH}$. While the chemistry of open-ocean waters surrounding coral reefs appears to exert at least some influence on reef-water chemistry (DeCarlo et al., 2015a; Yeakel et al., 2015), local benthic community metabolism (calcification and production) often drives significant changes (Shaw et al., 2012; Cyronak et al., 2014; Shamberger et al., 2014). NEC represents the balance between calcification and dissolution, whereas net ecosystem production (NEP) represents the balance between photosynthesis and respiration:

$$
\begin{gathered}
\text { NEC: } \mathrm{Ca}^{2+}+\mathrm{CO}_{3}^{2-} \rightleftharpoons \mathrm{CaCO}_{3} \\
\text { NEP: } \mathrm{CO}_{2}+\mathrm{H}_{2} \mathrm{O} \rightleftharpoons \mathrm{CH}_{2} \mathrm{O}+\mathrm{O}_{2}
\end{gathered}
$$

As a result of community metabolism, the $\mathrm{pH}$ of water bathing corals may be higher (Ohde and van Woesik, 1999) or lower (Shamberger et al., 2014) than, and may not respond linearly to (Cyronak et al., 2014), the $\mathrm{pH}$ of the open ocean. Accurate predictions of coral reef futures therefore require an understanding of the processes that control rates of community metabolism, reef-water carbonate chemistry, and any feedbacks between the two.

Chemical feedbacks between NEP and NEC are expected based on their relation with the seawater carbonate system. Community metabolism perturbs the carbonate system equilibria:

$$
\mathrm{H}_{2} \mathrm{O}+\mathrm{CO}_{2} \rightleftharpoons \mathrm{H}_{2} \mathrm{CO}_{3} \rightleftharpoons \mathrm{H}^{+}+\mathrm{HCO}_{3}^{-} \rightleftharpoons 2 \mathrm{H}^{+}+\mathrm{CO}_{3}^{2-}
$$


where $\mathrm{CO}_{2}\left(\mathrm{CO}_{3}^{2-}\right)$ is produced from calcification (photosynthesis) because the removal of $\mathrm{CO}_{3}^{2-}\left(\mathrm{CO}_{2}\right)$ shifts the carbonate system (Eq. 5.3) to the left (right). Therefore, NEC and NEP are linked because products of one are reactants of the other. This feedback system has potentially important ramifications for the sensitivity of coral reefs to ocean acidification. Photosynthesis by seagrass and algae has been proposed as a potential mechanism buffering coral reefs from ocean acidification because it removes $\mathrm{CO}_{2}$ from reef water (Kleypas et al., 2011; Smith et al., 2013; Andersson et al., 2014). However, the role of this chemical feedback system in modulating reefwater carbonate chemistry has so far been difficult to isolate because NEC, NEP, and reef-water $\mathrm{pH}$ are usually dominated by diurnal cycles that create strong correlations, but do not necessarily reflect causation (Andersson and Mackenzie, 2011). Identifying the mechanistic, interactive links between community metabolism and reef-water carbonate chemistry is key for understanding the sensitivity of coral reef ecosystems to $\mathrm{CO}_{2}$-driven climate change, including any compounding effects of ocean warming or changes in benthic community structure or health.

In this study, we investigated the drivers of reef-water carbonate chemistry and the metabolic rates of NEC and NEP on Dongsha Atoll, a remote coral reef in the northern South China Sea (SCS) (Fig. 1). Here, relatively high abundances of benthic flora and fauna on a wide and shallow reef flat impose dramatic changes in reef-water carbonate chemistry. We evaluate potential drivers of NEC, including elevated reefwater $\mathrm{pH}$, coral community structure, and local oceanographic effects. Further, we tracked the community metabolism response to a transient, week-long coral bleaching event, which provided a novel opportunity to identify the sensitivity of reef-water carbonate chemistry, and NEC and NEP to changes in community health and function. Overall, we explore potential links between NEC and NEP arising from chemical feedbacks within the seawater carbonate system, and we consider how changes in benthic community metabolism will modulate the sensitivity of coral reef ecosystems to future open-ocean acidification. 


\subsection{Methods}

\subsubsection{Experimental design}

The SCS is a tropical to sub-tropical ocean basin extending from the equator to the Tropic of Cancer in the far western Pacific Ocean (Fig. 5-1). A monsoon climate dominates the wind field in this region, with southwesterlies during the wet season from May to October, and northeasterlies during the dry season from November to April (Wong et al., 2007). Surface ocean currents follow the wind pattern, with a basin-scale anti-cyclonic gyre in summer and a cyclonic gyre in winter (Shaw and Chao, 1994). Within the centers of these gyres, high sea surface temperatures $(>22$ ${ }^{\circ} \mathrm{C}$ throughout the year) produce a sharply defined pycnocline (Shaw and Chao, 1994; Gawarkiewicz et al., 2004), maintaining strong stratification and oligotrophic surface waters (Wong et al., 2007). Coral reef ecosystems are abundant in the coastal waters of the South China Sea, including a portion of the Coral Triangle, the epicenter of coral reef biodiversity. Our study was conducted on Dongsha Atoll $\left(20.8^{\circ} \mathrm{N}, 116.7^{\circ} \mathrm{E}\right)$, a ring-shaped coral reef ecosystem on the northern SCS shelf. On the western margin of the atoll is Dongsha Island, which is bordered to the north and south by $5 \mathrm{~m}$ deep channels into the large lagoon. Fringing the rest of the atoll is an extensive reef flat that is 1-3 $\mathrm{m}$ deep (Fig. 5-1).

We quantified ecosystem production and calcification rates based on tracking changes in carbonate chemistry as seawater flows from the open ocean, across the shallow reef flat of Dongsha Atoll. In June 2014, we collected seawater samples both offshore and on the eastern reef flat, while simultaneously characterizing the flow of water with current profilers. Additional data were collected to describe the benthic cover, and the physical setting on the reef flat, including photosynthetically active radiation (PAR), temperature, wind speed, and sea level. The instruments deployed and their roles in the experimental design are listed in Table 5.1. We also observed a transient coral bleaching event on the reef flat in late May and early June 2014, in response to a $5{ }^{\circ} \mathrm{C}$ temperature rise over the course of just 2-3 weeks (Fig. S1). Although we did not precisely quantify the extent of bleaching, all of the massive Porites 
Figure 5-1: Map of Dongsha Atoll in the northern South China Sea. (a) Regional map, (b) satellite image of Dongsha Atoll, and (c) study location and sampling stations on the eastern margin of the atoll. In (c), bathymetry data from Shih et al. (2011) are overlaid on the satellite imagery. Offshore samples were collected at station ED, located $80 \mathrm{~km}$ east of the atoll, and fore reef samples were collected at station E1. Instruments were deployed across the reef flat (Table 1), but the primary location for reef-water sampling was E5, located $2 \mathrm{~km}$ west of the reef crest.

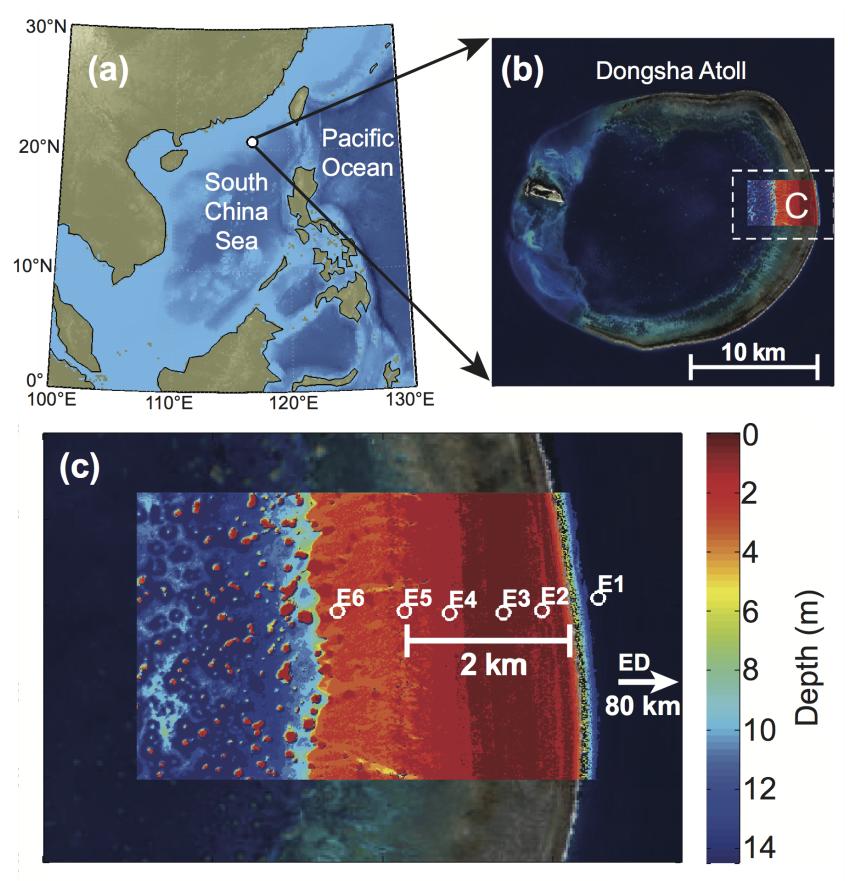

colonies, which compose $>30 \%$ of coral cover at station E5, appeared bleached. The bleaching event lasted less than 2 weeks, after which all of the coral colonies recovered their pigmentation.

Ecological surveys were conducted at 8 stations across the eastern reef flat between 29 May and 7 June 2015, following a protocol similar to previously established methods for characterizing benthic cover on coral reefs (Golbuu et al., 2007). At each station, 5x $50 \mathrm{~m}$ transect tapes were laid out and the seafloor was photographed every meter along each tape ( $0.5 \mathrm{~m}$ by $0.5 \mathrm{~m}$ image area), for a total of 250 photographs per station. Transects were oriented N-S (along-shore) and spaced $5 \mathrm{~m}$ apart (crossshore). Images were analyzed using Coral Point Count (Kohler and Gill, 2006) with 5 randomly placed points per image identified to coral genera or benthic substrate type (Table 5.2).

Bathymetry surveys were conducted across the reef flat between station E5 and the reef crest. A Reefnet Sensus Ultra pressure logger recording every $1 \mathrm{~s}$ was attached to a lead weight and dragged along the bottom following an E-W (cross-shore) transect line. A Garmin 650 logging GPS was attached to a buoy and maintained above the pressure logger. We synced the depth and location data using the time logs from 
both the pressure logger and the GPS. The depth data were adjusted to mean sea level based on the local sea level at the time of surveying.

Table 1. Experimental design and instrument deployments.

\begin{tabular}{|c|c|c|c|c|}
\hline Site & Location & Depth (m) & Instruments / activity & Purpose \\
\hline ED & $20.699^{\circ} \mathrm{N} 117.721^{\circ} \mathrm{E}$ & 1200 & OR3 water sampling station & $\begin{array}{l}\text { Characterize depth profile of nutrients for comparison of } \\
\text { temperature-nitrate relationship to that on the fore reef }\end{array}$ \\
\hline E1 & $20.7008^{\circ} \mathrm{N} 116.9252^{\circ} \mathrm{E}$ & 25 & $\begin{array}{l}\text { Seafet } \mathrm{pH}, \mathrm{SBE}-37 \mathrm{~T} / \mathrm{S} / \mathrm{O}_{2} \\
\text { SBE- } 56 \text { on buoy at } 10 \mathrm{~m} \text { depth / } \\
\text { OR3 water sampling station }\end{array}$ & $\begin{array}{l}\text { Characterize chemistry of source-water to the reef, capture } \\
\text { internal wave signal }\end{array}$ \\
\hline E2 & $20.6993^{\circ} \mathrm{N} 116.9186^{\circ} \mathrm{E}$ & 0.8 & $\begin{array}{l}\text { SAMI pH, SBE- } 37 \mathrm{~T} / \mathrm{S} \text {, } \\
\text { Seagauge } \mathrm{P} / \text { Benthic survey }\end{array}$ & $\begin{array}{l}\text { T/S properties of incoming water to the reef flat for sTA and } \\
\text { SDIC calculations, local sea level from pressure / describe } \\
\text { benthic community }\end{array}$ \\
\hline $\mathrm{E} 2.5$ & $20.6992^{\circ} \mathrm{N} 116.9163^{\circ} \mathrm{E}$ & 0.8 & Benthic survey & Describe benthic community \\
\hline E3 & $20.6991^{\circ} \mathrm{N} 116.9140^{\circ} \mathrm{E}$ & 0.7 & $\begin{array}{l}\text { Nortek Aquadopp ADP / } \\
\text { Benthic survey }\end{array}$ & $\begin{array}{l}\text { Validate assumption of constant flow direction across reef flat } \\
\text { transect / describe benthic community }\end{array}$ \\
\hline E3.5 & $20.6990^{\circ} \mathrm{N} 116.9109^{\circ} \mathrm{E}$ & 0.7 & Benthic survey & Describe benthic community \\
\hline E4 & $20.6990^{\circ} \mathrm{N} 116.9077^{\circ} \mathrm{E}$ & 0.8 & Seagauge $\mathrm{P}$ / Benthic survey & Local sea level from pressure / describe benthic community \\
\hline E4.5 & $20.6991^{\circ} \mathrm{N} 116.9051^{\circ} \mathrm{E}$ & 0.9 & Benthic Survey & Describe benthic community \\
\hline E5 & $20.6993^{\circ} \mathrm{N} 116.9024^{\circ} \mathrm{E}$ & 2.0 & $\begin{array}{l}\text { RAS, SAMI pH, SBE- } 37 \mathrm{~T} / \mathrm{S} \text {, } \\
\text { Nortek Aquadopp ADP, Onset } \\
\text { Hobo U26 } \mathrm{O}_{2} \text {, Wetlabs ECO- } \\
\text { PAR, eKo meteorological } \\
\text { station / Benthic survey }\end{array}$ & $\begin{array}{l}\text { Collect water samples via RAS for NEC/NEP calculations, pH } \\
\text { to validate TA/DIC collected in RAS, T/S properties of RAS } \\
\text { samples to calculate } \rho, \mathrm{O}_{2} \text { to validate NEP, ADP to estimate } \\
\text { reef water residence time, meteorological station to estimate } \\
\mathrm{CO}_{2} \text { gas exchange rates / describe benthic community }\end{array}$ \\
\hline E6 & $20.6993^{\circ} \mathrm{N} 116.8945^{\circ} \mathrm{E}$ & 2.6 & Seagauge $\mathrm{P} /$ Benthic survey & Local sea level from pressure / describe benthic community \\
\hline
\end{tabular}

Table 2. Benthic survey results. Benthic type reported as $\%$ areal cover; coral genera reported as $\%$ of total live coral cover.

\begin{tabular}{|lllll|llll|}
\hline Site & $\begin{array}{l}\text { CCA } \\
\text { (\%) }\end{array}$ & $\begin{array}{l}\text { Fleshy } \\
\text { algae (\%) }\end{array}$ & $\begin{array}{l}\text { Seagrass } \\
\text { (\%) }\end{array}$ & $\begin{array}{l}\text { Live } \\
\text { coral (\%) }\end{array}$ & $\begin{array}{l}\text { Acropora } \\
\text { (\%) }\end{array}$ & $\begin{array}{l}\text { Pavona } \\
\mathbf{( \% )}\end{array}$ & $\begin{array}{l}\text { Porites } \\
\mathbf{( \% )}\end{array}$ & $\begin{array}{l}\text { Stylophora } \\
\text { (\%) }\end{array}$ \\
\hline E2 & 15 & 26 & 2 & 6 & 15 & 0 & 2 & 83 \\
E2.5 & 4 & 17 & 10 & 24 & 24 & 0 & 29 & 47 \\
E3 & 1 & 8 & 38 & 27 & 35 & 0 & 6 & 59 \\
E3.5 & 1 & 10 & 37 & 23 & 40 & 0 & 1 & 59 \\
E4 & 0 & 21 & 2 & 33 & 5 & 6 & 0 & 89 \\
E4.5 & 0 & 34 & 13 & 16 & 41 & 9 & 17 & 33 \\
E5 & 0 & 19 & 13 & 26 & 48 & 6 & 38 & 8 \\
E6 & 0 & 3 & 78 & 0 & 0 & 0 & 0 & 0 \\
Mean E2-E5 & $\mathbf{3}$ & $\mathbf{1 9}$ & $\mathbf{1 6}$ & $\mathbf{2 2}$ & $\mathbf{2 9}$ & $\mathbf{3}$ & $\mathbf{1 4}$ & $\mathbf{5 3}$ \\
\hline
\end{tabular}

\subsubsection{Carbonate chemistry measurements}

Seawater sampling was conducted on the fore reef (station E1) of Dongsha Atoll in order to characterize the total alkalinity (TA) and dissolved inorganic carbon (DIC) concentrations of seawater bathing the atoll. During 4-5 June 2014, seawater samples were collected at 2, 5, and $10 \mathrm{~m}$ depths every three hours at station E1 using a 
Niskin bottle rosette deployed from the Taiwanese vessel Ocean Researcher 3 (OR3). These samples were analyzed for TA, DIC, and salinity. Two additional surface water samples were collected at E1 from a small boat, one each on 3 and 18 June 2014. All TA/DIC samples were collected in $300 \mathrm{~mL}$ glass bottles and were immediately poisoned with $0.05-0.1 \mathrm{~mL}$ saturated $\mathrm{HgCl}_{2}$ poison. Water samples were stored in the dark at ambient temperature and then returned to a shore-based laboratory for analysis. DIC was determined by measuring the infrared absorption of the $\mathrm{CO}_{2}$ released upon the acidification of the sample by using an Apollo SciTech model ASC3 DIC analyzer. TA was determined by an acidimetric Gran titration with an Apollo SciTech model AS-ALK2 alkalinity titrator. The precisions in the determination of TA and DIC were $\pm 2 \mu \mathrm{eq} \mathrm{kg}^{-1}$ and $\pm 2 \mu \mathrm{mol} \mathrm{kg} \mathrm{kg}^{-1}$, respectively. Details of the analyses are given in Guo and Wong (2015). Salinity samples were collected in 125 $\mathrm{mL}$ glass bottles and analyzed with a Guildline autosal with a precision of \pm 0.003 .

On the reef flat, seawater samples were collected over multiple diurnal cycles at station E5 for carbonate chemistry analyses. A McLane Research Labs Remote Access Sampler-500 (RAS) was programmed to collect $450 \mathrm{~mL}$ seawater samples every two hours in gastight Kynar Luer bags, in which $0.2 \mathrm{~mL}$ of saturated $\mathrm{HgCl} 2$ poison was added prior to sampling (see Shamberger et al. (2011) for additional details regarding the application of the RAS for community metabolism measurements). Two 4-day RAS deployments were conducted, one during the transient bleaching event 3-6 June 2014 and another deployment post-bleaching between 10-14 June 2014. Samples collected by the RAS were transferred to $300 \mathrm{~mL}$ glass bottles for transportation to the laboratory where TA and DIC were determined as in the discrete samples collected onboard the ship. Seawater density corresponding to each RAS sample was calculated with the standard 48-term equation (McDougall et al., 2009), using temperature and salinity measured with a Seabird SBE-37 MicroCAT mounted on the RAS frame and calibrated against salinity measured in bottle samples. The TA and DIC of RAS samples, combined with temperature and salinity, were also used to calculate seawater $\mathrm{pH}, \Omega_{\text {Arag }}$ and $\mathrm{pCO}_{2}$ using the program CO2SYS (Lewis et al., 1998) with the acidity constants of (Mehrbach, 1973) as refit by (Dickson and Millero, 
1987).

The TA and DIC of our RAS samples were validated by comparison to handcollected samples and to independent $\mathrm{pH}$ measurements. We collected 7 discrete samples by opening bottles next to the RAS intake at the same times that the RAS collected samples. The average absolute differences in TA and DIC between the hand-

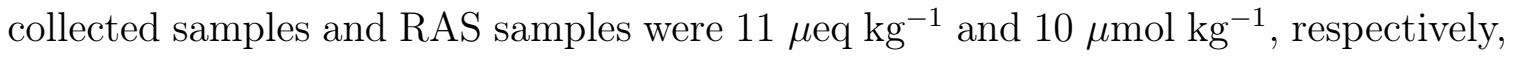
with no significant biases. In addition, we measured in situ $\mathrm{pH}$ (total scale) with a SAMI pH meter deployed alongside the RAS, and we used these data to calculate TA from measured DIC and $\mathrm{pH}$, and to calculate DIC from measured TA and $\mathrm{pH}$. Strong correlations were found between calculated and measured values $\left(\mathrm{r}^{2}=0.97\right.$ for $\mathrm{TA}$, and $\mathrm{r}^{2}=0.99$ for $\left.\mathrm{DIC}\right)$. We used the average absolute differences between measured TA and calculated TA $\left(15 \mu \mathrm{eq} \mathrm{kg}^{-1}\right)$, and between measured DIC and

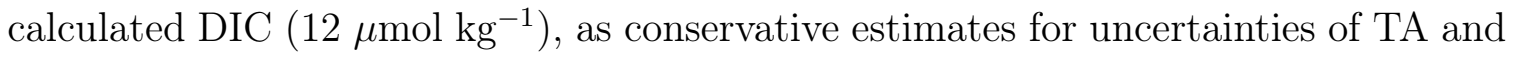
DIC in our RAS samples. While these uncertainties are several times larger than the analytical precisions, the TA and DIC changes in our study were large enough to clearly detect metabolic signals (mean absolute differences in TA and DIC between

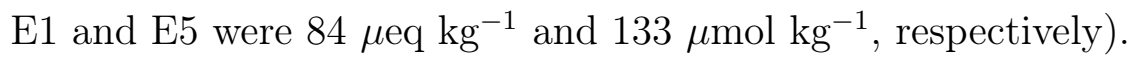

Using our seawater samples, we quantified the relative influences of NEC and NEP on the seawater carbonate system (Fig. 5-2). However, this information alone is insufficient to calculate metabolic rates for comparison to other reef systems. Only by coupling our TA and DIC measurements with estimates of reef water residence times can we quantify these rates.

\subsubsection{Reef water residence time}

We estimated residence time of water flowing over the reef flat under a quasi-Lagrangian framework in which we traced the trajectories of water parcels across the reef indirectly with current velocity and bathymetry data. Current velocities were measured every 4 minutes at station E5 with a Nortek Aquadopp acoustic Doppler current profiler (ADP). To test whether flow direction and transport were conserved across the reef flat, a second ADP was deployed at station E3, approximately halfway between 


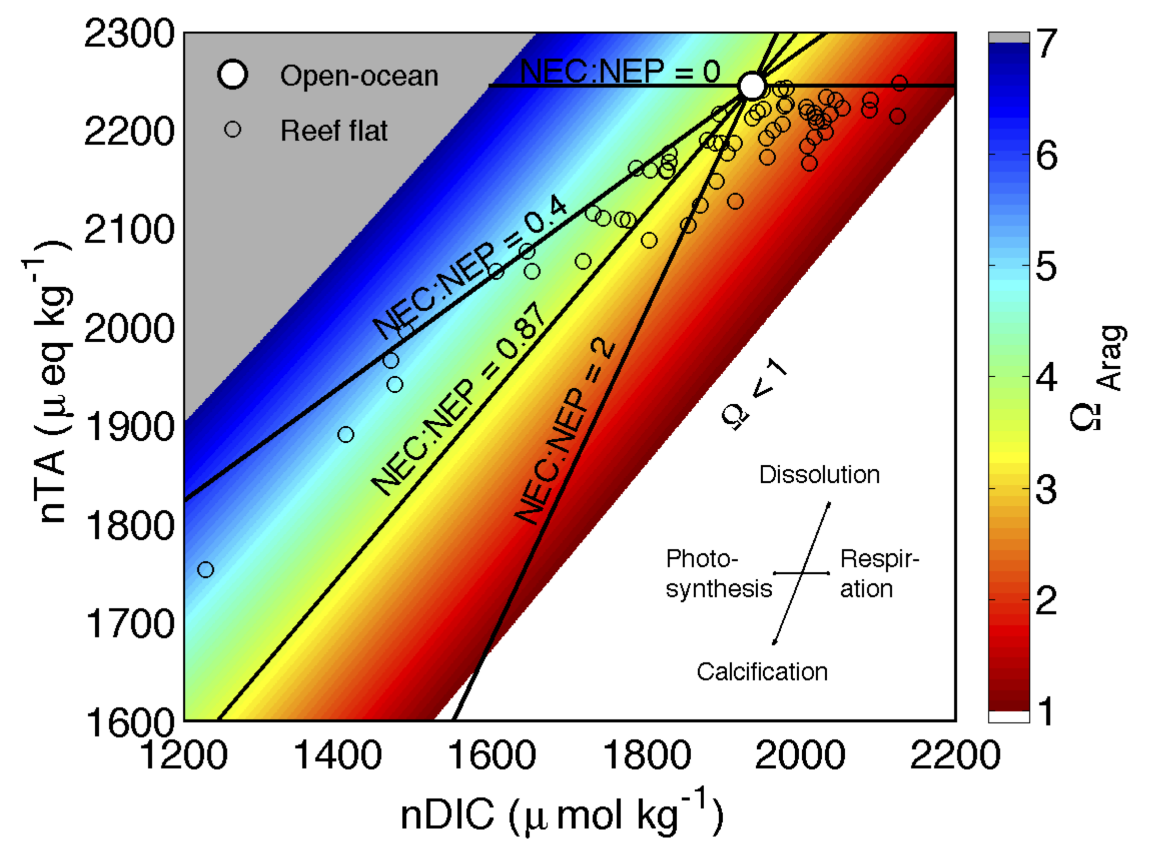

Figure 5-2: The seawater $\mathbf{C O}_{2}$ system as a function of nDIC and nTA. Colors show $\Omega_{\text {Arag }}$ contours (calculated at $25{ }^{\circ} \mathrm{C}$ ), with white indicating undersaturation $\left(\Omega_{\text {Arag }}<1\right.$ ). The vector diagram in the lower right shows the predicted effects of community metabolic processes on TA and DIC. The large white circle shows the seawater composition of the open ocean surrounding Dongsha Atoll, the small open circles show our reef flat (station E5) measurements, and solid black lines show the effects of NEC and NEP imposed on the offshore source-water for various NEC:NEP ratios. A NEC:NEP ratio of 0.87 maintains approximately constant $\Omega_{\text {Arag }}$, whereas higher ratios decrease $\Omega_{\text {Arag }}$ and lower ratios increase $\Omega_{\text {Arag }}$.

station E5 and the reef crest. We found that the major axis of flow direction was consistent within $2^{\circ}$ and that transport was strongly correlated $\left(\mathrm{r}^{2}=0.84\right)$, but was $12 \%$ less at E3 compared to E5 (major axis regression slope $=0.88$ ). This difference in transport across the reef flat can be explained by assuming that water flows inward toward the lagoon symmetrically around the ring of the atoll. Transport increases toward the lagoon-ward side of the reef flat because the perimeter of the inside of the reef flat is less than that of the outside edge of the atoll. We calculated the transport at any location on the reef flat based on the transport measured at E5 with the following expression:

$$
q(x)=q_{E 5} \frac{12,500-x_{E 5}}{12,500-x}
$$


where $q$ is transport $\left(\mathrm{m}^{2} \mathrm{~s}^{-1}\right), x$ is distance in meters from the reef crest toward the lagoon, $q_{E 5}$ is transport measured at station E5, and 12,500 meters is the approximate distance from the reef crest to the center of the lagoon. Following this adjustment to transport across the reef flat, the mean difference in transport between E5 and E3 was less than 1\%. This close agreement allows us to quantify the velocity at any location on the reef flat based on water depth and velocity measurements at a fixed point (station E5). For each seawater sample collected at station E5, residence time $(\tau)$ of the sampled water parcel was estimated by back-tracking in time from E5 to the reef crest using depth-averaged cross-shore current velocity $(u)$ and water depth (h) across the reef flat (Fig. 5-3). The location $x$ along the reef flat (i.e. distance from the reef crest) of a water parcel is estimated at any time $t$ by:

$$
x(t)=\int_{0}^{t} \frac{u_{E 5}(t) h_{E 5}(t)}{h(t, x)} d t
$$

where $t$ is time in seconds, $\mathrm{u}_{E 5}$ is the depth-averaged current velocity $\left(\mathrm{m} \mathrm{s}^{-1}\right)$ measured by the ADP at station $\mathrm{E} 5, \mathrm{~h}_{E 5}$ is water depth at $\mathrm{E} 5$ based on pressure measurements from the ADP, and $h(t, x)$ is the local water depth at time $\mathrm{t}$ and location $\mathrm{x}$ along the path of each water parcel traversing the reef flat. In practice, Eq. 5.5 must be integrated stepwise from $x=2020 \mathrm{~m}$ (i.e. the distance from E5 to the reef crest) backward in time every 4 minutes (ADP sampling interval) until each water parcel is traced to the reef crest (Fig. 5-3). With this approach, we calculated the residence time of each water parcel as the difference between the time that it crossed the reef crest and the time it was sampled by the RAS at station E5. The time-averaged depth of a water parcel is:

$$
\bar{h}=\frac{1}{\tau} \int_{0}^{\tau} h(t, x) d t
$$

which is calculated following the same step-wise approach described above.

Uncertainty of $\tau$ for each seawater sample was estimated with a Monte Carlo method, repeating the $\tau$ calculations $10^{3}$ times while randomly adding measurement uncertainty in the current velocity $\left(1 \sigma=0.04 \mathrm{~m} \mathrm{~s}^{-1}\right.$ and assuming a Gaussian distribution) at each time step, and excluding any water parcels traced into the lagoon 
(a)

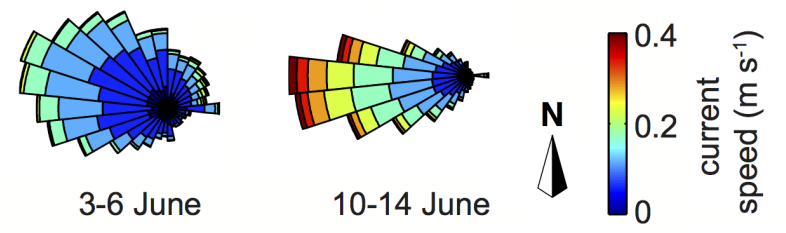

(b)
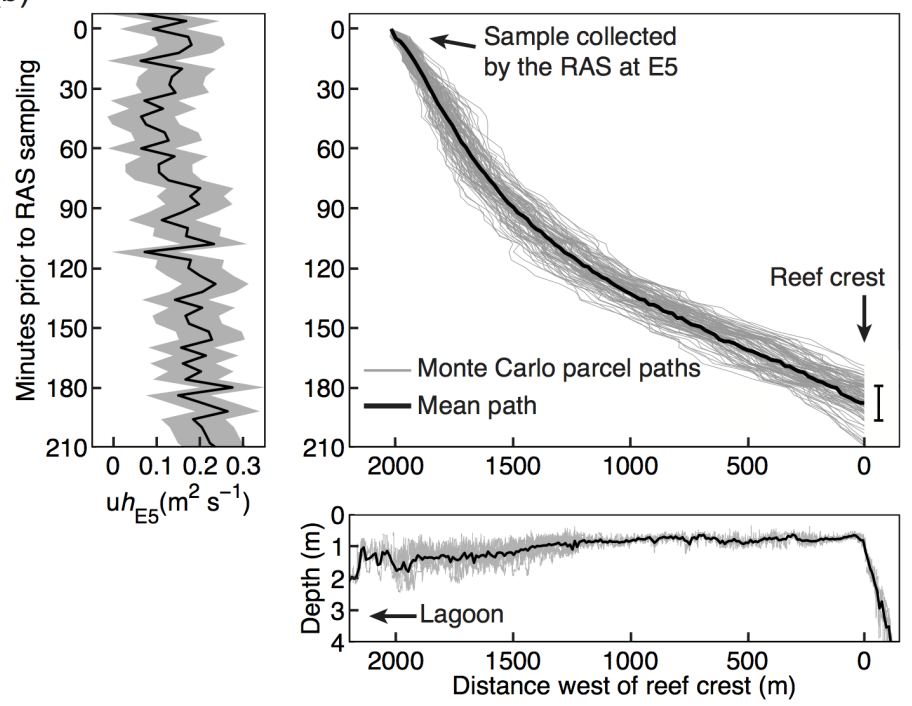

Figure 5-3: Reef water residence time. (a) Current velocities at station E5 during the two RAS deployments: 3-6 June and 10-14 June. The angle of each wedge indicates the compass direction of water flow, the length of each wedge indicates the relative frequency of currents flowing in that direction, and the colors on the wedge indicate the distribution of velocities in that direction. During 10-14 June, reef water was persistently flowing from the ocean toward to the lagoon (i.e., westward) but during 3-6 June, current direction switched between eastward and westward depending on the tide. (b) Quasi-Lagrangian calculation of reef water residence time. Left panel: transport $(u h)$ measured at station E5 over 3.5 hours during 10 June (positive westward). Gray error bounds represent measurement uncertainty of the ADP. Bottom panel: bathymetry profile across the reef flat. Gray lines represent individual bathymetry transects with 1-3 $\mathrm{m}$ resolution. Thick black line shows mean bathymetry profile in $10 \mathrm{~m}$ horizontal bins. The RAS was located 2020 meters from the reef crest. Main panel: seawater parcel tracing for one sample collected by the RAS on 10 June. Gray lines show the parcel trajectories for each of 100 Monte Carlo simulations. Tracing the seawater parcel begins with collection at the RAS, at known time and distance from the reef crest. The water parcel is then traced backward in time until it reaches the reef crest. Uncertainty in the current velocity at each time step imposes variability in parcel trajectories among Monte Carlo simulations. The thick black line shows the mean trajectory averaged across all iterations. The black error bar shows the $1 \sigma$ uncertainty of residence time for this water parcel.

$(x=3000)$ or that traversed the reef crest at lowest spring tides when water depth at the reef crest was $<30 \mathrm{~cm}$ and boulders on parts of the reef became emergent. This analysis yielded a total of 60 reliable measurements of paired NEC and NEP rates. 


\subsubsection{Reef flat metabolism}

Community metabolic rates were quantified by combining estimates of reef-water residence time with measured carbonate chemistry changes. Exploiting the predictable ways in which community metabolism alters reef water carbonate chemistry (Eqs. 1-2), we can determine NEC and NEP rates by tracking changes in seawater TA and DIC over time (Langdon et al., 2010). Both TA and DIC are depleted by calcification, but only DIC is depleted by productivity. These metabolic rates are calculated as follows:

$$
\begin{gathered}
\mathrm{NEC}=\frac{\mathrm{TA}_{E 1}-\mathrm{TA}_{E 5}}{2 \tau} \bar{h} \rho \\
\mathrm{NEP}=\frac{\mathrm{DIC}_{E 1}-\mathrm{DIC}_{E 5}}{\tau} \bar{h} \rho-\mathrm{NEC}-F_{C O_{2}}
\end{gathered}
$$

where NEC and NEP are in units of $\mathrm{mmol} \mathrm{CaCO}_{3} \mathrm{~m}^{-2} \mathrm{hr}^{-1}$ and mmol organic carbon $\mathrm{m}^{-2} \mathrm{hr}^{-1}$ respectively, $\bar{h}$ is the time-averaged depth as the water parcel is traced across the reef flat and is calculated from bathymetry and sea level, $\rho$ is seawater density $(\mathrm{kg}$ $\left.\mathrm{m}^{-3}\right), \tau$ is the residence time of a parcel of water on the reef (hr), the factor 2 appears in the denominator of the NEC equation because 2 equivalents of TA are removed for each mole of $\mathrm{CaCO}_{3}$ formed, and NEC is subtracted from NEP to account for the depletion (addition) of DIC by the precipitation (dissolution) of $\mathrm{CaCO}_{3} \cdot \mathrm{F}_{\mathrm{CO}_{2}}$ is the $\mathrm{CO}_{2}$ air-sea gas exchange flux $\left(\mathrm{mmol} \mathrm{CO}_{2} \mathrm{~m}^{-2} \mathrm{hr}^{-1}\right)$ :

$$
F_{\mathrm{CO}_{2}}=k s \rho\left(\mathrm{CO}_{2-\text { water }}-\mathrm{CO}_{2-\text { air }}\right)
$$

where $k$ is the gas transfer velocity $\left(\mathrm{m} \mathrm{hr}^{-1}\right), s$ is the solubility of $\mathrm{CO}_{2}$ in seawater ( $m m o l ~ \mathrm{~kg}^{-1}$ atm $\mathrm{CO}_{2}^{-1}$ ) calculated from temperature and salinity (Weiss, 1974), and $\mathrm{CO}_{2-\text { air }}$ was assumed to be $400 \mu$ atm. The $\mathrm{CO}_{2}$ transfer velocity is calculated with the parameterization of (Ho et al., 2006) based on wind speed measured at $6 \mathrm{~m}$ altitude on a scaffolding tower constructed at station E5 and adjusted to $10 \mathrm{~m}$ altitude wind speed following the calculations of (Johnson, 1999), and converted to in situ temperature at salinity 35 following Wanninkhof (1992). We estimated uncertainty in NEC and NEP rates by propagating uncertainty of offshore TA and DIC, reef flat TA and DIC, 
and $\tau$. Mean relative standard deviations of NEC and NEP rates were $29 \%$ and $27 \%$, respectively. The DIC-based NEP rates were validated by comparison to dissolved $\mathrm{O}_{2}$-based NEP rates (Supporting Information and Fig. S2).

\subsection{Results}

\subsubsection{Open-ocean seawater chemistry}

The TA and DIC of each fore reef sample were normalized to salinity 34 (approximately the average offshore salinity) with the equations

$$
\begin{aligned}
& \mathrm{nTA}=\frac{34 \mathrm{TA}_{\text {measured }}}{\mathrm{S}_{\text {measured }}} \\
& \mathrm{nDIC}=\frac{34 \mathrm{DIC}_{\text {measured }}}{\mathrm{S}_{\text {measured }}}
\end{aligned}
$$

to compare to other studies of open-ocean carbonate chemistry. nTA and nDIC on the fore reef were $2241 \pm 6 \mu \mathrm{eq} \mathrm{kg}^{-1}$ and $1936 \pm 7 \mu \mathrm{mol} \mathrm{\textrm {kg } ^ { - 1 }}(1 \sigma)$, respectively. These results are within uncertainty of nTA and nDIC in samples collected at 10-20 m depth at station "ED" located in the open-ocean $80 \mathrm{~km}$ east of Dongsha Atoll (nTA of $2240 \pm 2 \mu \mathrm{eq} \mathrm{kg} \mathrm{kg}^{-1}$ and nDIC of $1927 \pm 3 \mu \mathrm{mol} \mathrm{kg}-1$ ), and within uncertainty of other published relationships between TA/DIC and salinity for the tropical Pacific Ocean (Lee et al. (2006) relationship predicts nTA of 2239-2243 $\mu \mathrm{eq} \mathrm{kg}^{-1}$ between 25-30 ${ }^{\circ} \mathrm{C}$ ) and the South China Sea (Guo and Wong (2015) relationship predicts nTA of $2249 \pm 8 \mu \mathrm{eq} \mathrm{kg}^{-1}$ and $\mathrm{nDIC}$ of $\left.1940 \pm 9 \mu \mathrm{mol} \mathrm{kg}-1\right)$. The consistency between our fore reef, open-ocean, and published nTA and nDIC values gives us confidence that our nTA and nDIC estimates on the Dongsha Atoll fore reef are representative of the background oceanic composition, and that we can reliably estimate nTA and nDIC of water flowing onto the reef for times when only salinity, and not TA or DIC, was measured.

\subsubsection{Reef flat metabolism}

We calculated NEC and NEP based on our nTA and nDIC measurements at station E5, combined with estimates of water residence time on the reef flat. Reef-water 

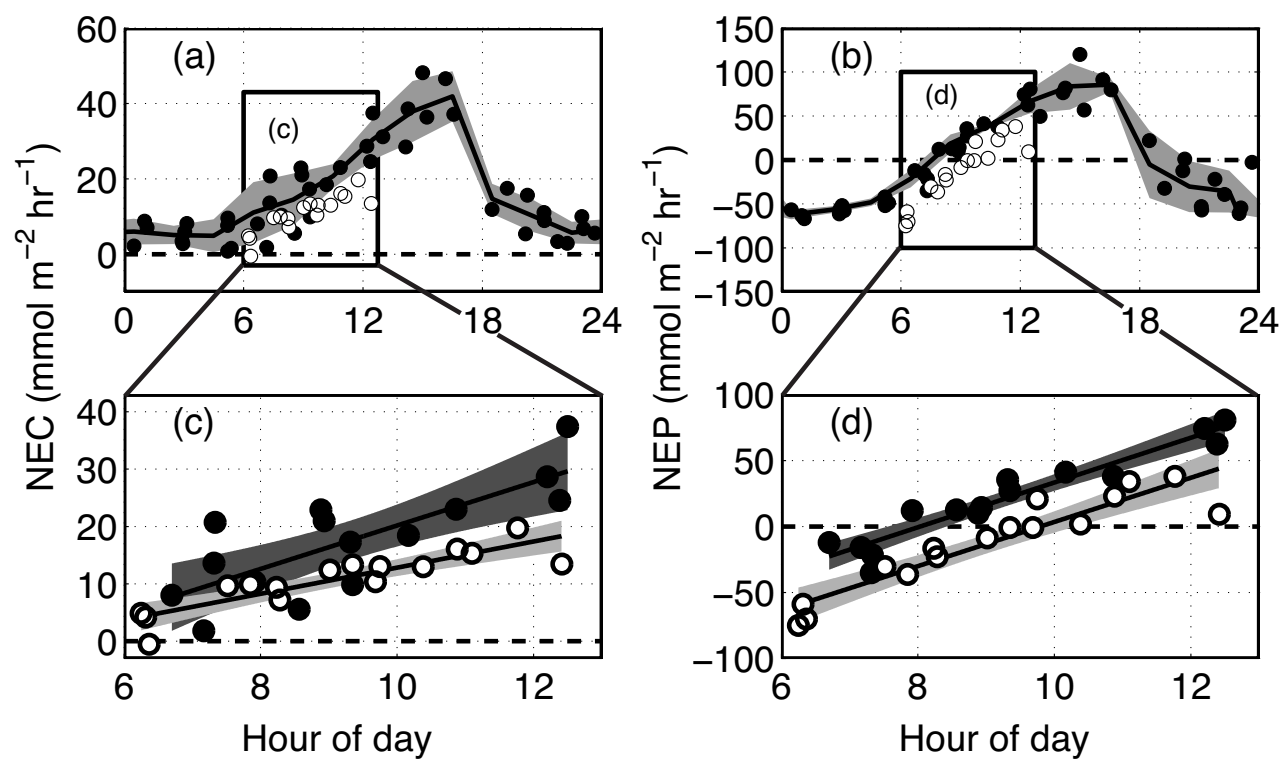

Figure 5-4: Diurnal compilations of NEC (a,c) and NEP (b,d) rates. Dashed horizontal lines indicate 0 rates that separate net calcification from dissolution and net photosynthesis from respiration. White and black circles indicate 3-6 June (during bleaching) and 10-14 June (post-bleaching) measurements, respectively. In $(a, b)$ the solid black line and gray shading represent the mean rates $\pm 1 \sigma$ in 2-hour bins, calculated using only the post-bleaching data. (c,d) Measurements during bleaching and post-bleaching overlap between approximately 06:00 and 12:30, and over this time the NEC and NEP rates during bleaching are significantly reduced (see Results section). Solid black lines are linear regression fits, and light and dark shading are $95 \%$ confidence intervals for during- and post-bleaching data, respectively. All points are plotted on the time axis as the mid-point between when the water parcel traversed the reef crest and the sampling time (see Supporting Information for further details).

residence times varied between 1 and 7 hours, nTA varied between 1754 and 2247 $\mu$ eq $\mathrm{kg}^{-1}$, and nDIC varied between 1229 and $2127 \mu \mathrm{mol} \mathrm{\textrm {kg } ^ { - 1 }}$ at station E5 (Fig. 5-2). NEC and NEP rates also changed throughout the course of a day (Fig. 5-4). Maximum NEC and NEP rates typically occurred in late afternoon, approximately the same time as maximum $\mathrm{O}_{2}, \mathrm{pH}$, and $\Omega_{\text {Arag }}$ (Fig. 5-5). During nighttime, NEC decreased to near zero, but we observed no significant net dissolution, which contrasts with most coral reefs studied to date (Table 5.3). Conversely, nighttime NEP was consistently negative (net respiration). NEP rates calculated based on O2 stoichiometry were in close agreement with the carbon-based estimates (Fig. S2). Minimum $\mathrm{O}_{2}$, $\mathrm{pH}$, and $\Omega_{\text {Arag }}$ all occurred shortly before dawn. Throughout our study, the ranges 

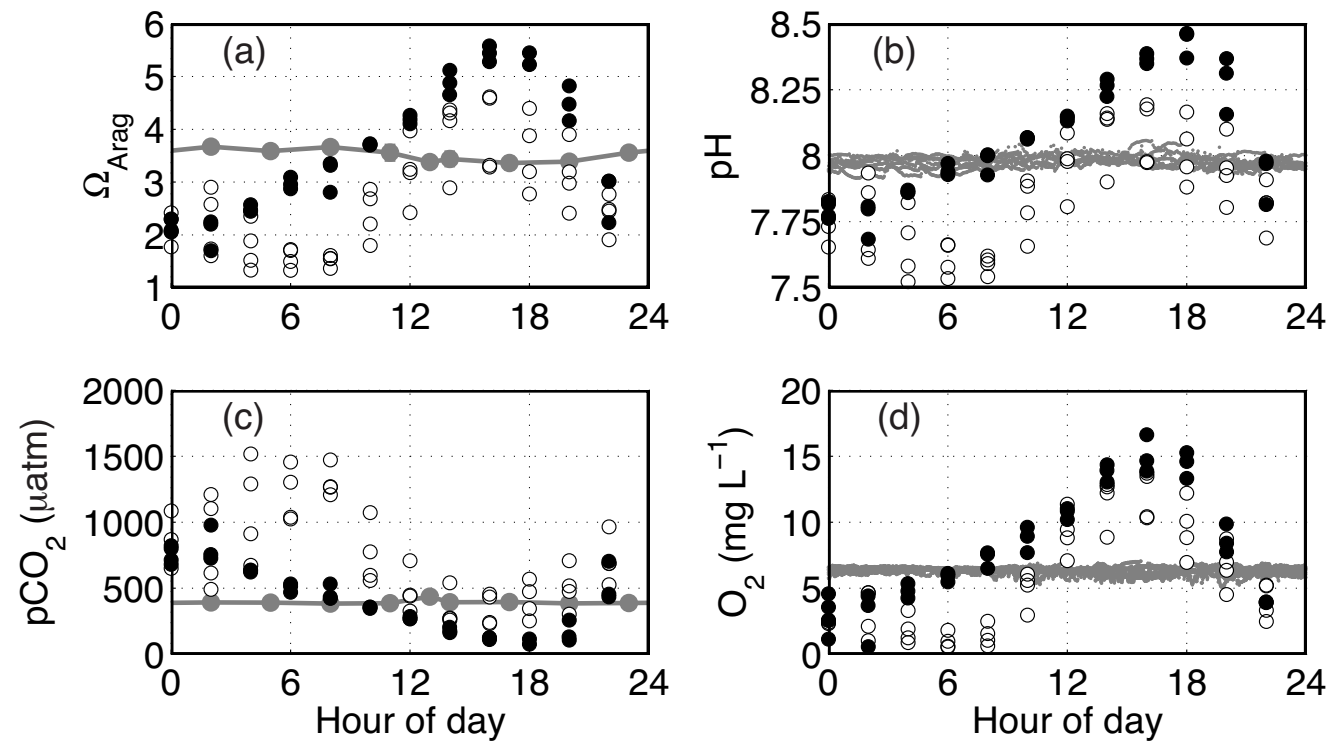

Figure 5-5: Diurnal compilations of seawater (a) $\Omega_{\text {Arag }}$, (b) pH, (c) $\mathbf{p C O}_{2}$, and (d) dissolved $\mathrm{O}_{2}$. Open and filled black circles indicate 3-6 June (during bleaching) and 1014 June (post-bleaching) measurements, respectively, on the reef flat at station E5, and gray points are open-ocean measurements from station $\mathrm{E} 1$ over the same time period as the reef flat measurements. The reef flat data were derived from RAS samples and an $\mathrm{O} 2$ sensor at E5, open-ocean $\mathrm{pH}$ and $\mathrm{O} 2$ were measured at E1, and open-ocean $\Omega_{\text {Arag }}$ and $\mathrm{pCO}_{2}$ were calculated from OR3 samples. $\Omega_{\text {Arag }}$ and $\mathrm{pH}$ are greatly elevated on the reef flat during the day, and in comparison they change relatively little in the surrounding open ocean. These carbonate system parameters follow similar diurnal patterns during and after the bleaching event, but they are all significantly $(\mathrm{p}<0.05$; two-sample t-tests) different during bleaching ( $\mathrm{pH}, \Omega_{\text {Arag }}$ and $\mathrm{O}_{2}$ decreased; $\mathrm{pCO}_{2}$ increased).

of NEC and NEP were between 0 and $47 \mathrm{mmol} \mathrm{CaCO}_{3} \mathrm{~m}^{-2} \mathrm{hr}^{-1}$, -64 and $118 \mathrm{mmol}$ $\mathrm{C} \mathrm{m}{ }^{-2} \mathrm{hr}^{-1}$, and the ranges of seawater chemical properties were $\mathrm{O}_{2} 0-18 \mathrm{mg} \mathrm{L}^{-1}$, $\mathrm{pCO}_{2}$ 76-1520 $\mu \mathrm{atm}, \mathrm{pH}$ 7.3-8.5, and $\Omega_{\text {Arag }}$ 1.3-5.6 (Fig. 5-4 and Fig. 5-5).

The multi-day metabolic rate time series were compiled to estimate diurnalaverage NEC and NEP for comparison with other coral reef systems worldwide (Table 5.3). During 10-14 June, persistent westward currents allowed us to capture full diurnal cycles. However, during 3-6 June westward flow occurred only during flood tides, and as a result our metabolic rate measurements only span daylight hours (Fig. 5-4 and Fig. S5). Therefore, we compare rates between 3-6 June and 10-14 June for the overlapping times of day, but we use only 10-14 June measurements to estimate diurnal-averaged metabolic rates. Mean metabolic rates were calculated in 2-hour 
bins and integrated over 24 hours (Fig. 5-4). This resulted in diurnal-average NEC of $390 \pm 90$ (1 standard error) mmol $\mathrm{CaCO}_{3} \mathrm{~m}^{-2}$ day $^{-1}$ and NEP of $100 \pm 360 \mathrm{mmol}$ $\mathrm{C} \mathrm{m}^{-2}$ day $^{-1}$.

We evaluated the effect of coral bleaching on the community metabolic rates by comparing NEC and NEP during the bleaching event (3-6 June) to post-bleaching (1014 June). Since our measurements during the bleaching event only span a portion of the diurnal cycle, we calculated the differences between the measured 3-6 June metabolic rates and the rates expected at the same times of day based on the 10-14 June diurnal cycle (Fig. 5-4). The residual NEC (-7 $\left.\pm 1 \mathrm{mmol} \mathrm{CaCO}_{3} \mathrm{~m}^{-2} \mathrm{hr}^{-1}\right)$ and NEP rates $\left(-31 \pm 4 \mathrm{mmol} \mathrm{C} \mathrm{m}{ }^{-2} \mathrm{hr}^{-1}\right)$ were significantly $(\mathrm{p}<0.05)$ different from zero, meaning that metabolic rates were reduced during the bleaching event relative to post-bleaching. Further, we tested whether the reduced NEC and NEP rates during bleaching were attributable to any differences in abiotic factors. We found that for any PAR or temperature level, NEC and NEP rates were lower during bleaching than post-bleaching, and multi regression analysis accounting for the combined influence of PAR, temperature, current speeds, and water depth still produced significant effects of bleaching on the metabolic rates (Figs. S3-4).

NEC and NEP were significantly $(\mathrm{p}<0.05)$ positively correlated with both linear and exponential type II (major axis) regressions (Fig. 5-6). However, investigation of the residuals of the linear regression showed clear structure and the NEC residuals were significantly correlated with NEP using a second-order polynomial, whereas NEC residuals of the exponential regression showed no clear structure and produced no significant correlation with NEP. The best-fit equation $( \pm 2 \sigma)$ was:

$$
\mathrm{NEC}=e^{0.015(0.003) \mathrm{NEP}+2.3(0.2)}
$$

where NEC and NEP are in units of mmol $\mathrm{CaCO}_{3} \mathrm{~m}^{-2} \mathrm{hr}^{-1}$ and $\mathrm{mmol} \mathrm{C} \mathrm{m} \mathrm{Ch}^{-1}$ respectively. There was no significant difference in the NEC to NEP relationship during- and post-bleaching (Fig. 5-6 and Figs. S6-7). 


\subsection{Discussion}

\subsubsection{Carbonate chemistry and community metabolism}

Anthropogenic $\mathrm{CO}_{2}$ emissions are forecast to drive changes in $\mathrm{pH}$ and $\Omega_{\text {Arag }}$ of 0.3 and 1.5 units, respectively, by the end of the 21st century in surface waters of the tropical oceans. These waters bath coral reefs, and the changes driven by ocean acidification are projected to cause declines in ecosystem calcification rates (Shamberger et al., 2011; Shaw et al., 2012; Bernstein et al., 2016). Yet these projections do not account for the potentially compounding effects of ocean warming or the processes that differentiate reef-water and open-ocean chemistry. Predicting the sensitivity of coral reef ecosystems to $\mathrm{CO}_{2}$-driven climate changes requires an understanding of the interactions between open-ocean acidification and the processes driving carbonate system changes in reef waters.

As open-ocean seawater flows onto coral reefs, benthic communities alter its carbonate chemistry. The reef flat of Dongsha Atoll is shallow $(1-3 \mathrm{~m})$, wide $(3 \mathrm{~km})$, and has high live benthic cover (61\% combined coral, algae and seagrass). TA and DIC fluxes are imposed by most of the benthic area (high living cover), chemical changes accumulate rapidly in the shallow water column, and these changes are integrated as seawater traverses the wide reef flat. On the Dongsha Atoll reef flat at station E5, TA and DIC depletions relative to the surrounding open ocean are as high as 481 $\mu$ eq $\mathrm{kg}^{-1}$ and $707 \mu \mathrm{mol} \mathrm{kg} \mathrm{kg}^{-1}$ respectively (Fig. 5-2), greater than those measured in water flowing across other coral reefs where $\mathrm{CO}_{2}$ with similar residence times and bathymetry (Shamberger et al., 2011; Shaw et al., 2014; Silverman et al., 2014; Kline et al., 2015).

Due to these changes in reef-water chemistry, calcifiers on the Dongsha reef flat build their shells and skeletons in seawater with elevated $\mathrm{pH}$ and $\Omega_{\text {Arag }}$. The vast majority of NEC (80\%) occurs during daytime, when reef-water $\mathrm{pH}$ and $\Omega_{\text {Arag }}$ reach as high as 8.5 and 5.0, respectively, compared to 8.0 and 3.4 in the surrounding open ocean (Fig. 5-5). Under these conditions, the diurnal-average NEC rate on Dongsha Atoll was greater than that measured for all other coral communities studied to 


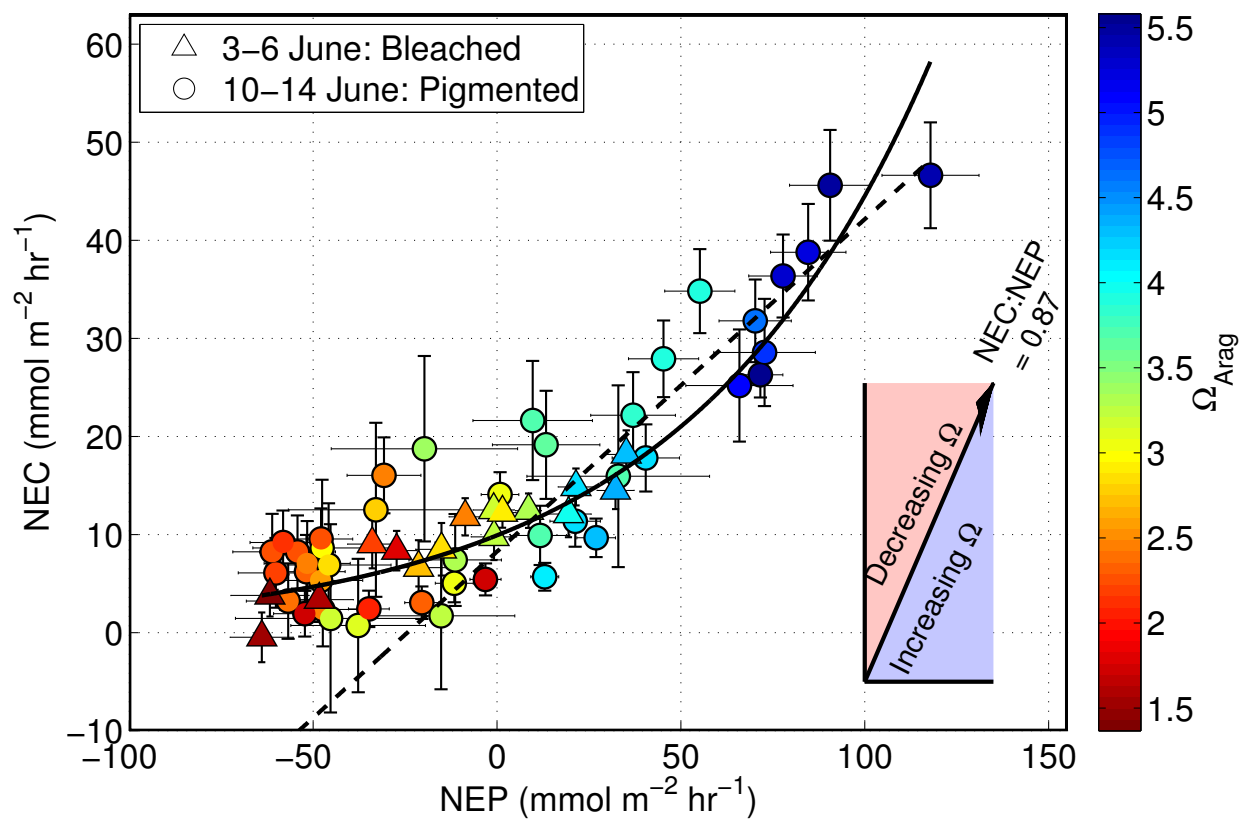

Figure 5-6: Interactive relationship between NEC, NEP, and $\Omega_{\text {Arag }}$. Triangles and circles indicate 3-6 June (bleaching) and 10-14 June (post-bleaching) measurements, respectively, and colors show $\Omega_{A r a g}$ at station E5. Solid black line is exponential fit between NEC and NEP. Theoretical vector in lower right shows the slope between NEC and NEP $(0.87)$ that maintains an approximately constant $\Omega_{\text {Arag }}$. Greater slopes decrease $\Omega_{\text {Arag }}$ and lesser slopes increase $\Omega_{\text {Arag }}$. The exponential curve is increasing in slope at higher NEP, but is always less than the 0.87 critical value, and thus the highest $\Omega_{\text {Arag }}$ values correspond to the highest NEC and NEP rates. The dashed black line shows a linear fit between NEC and NEP for only daylight hours and extrapolated to all hours of the day, showing that net dissolution would be expected during night based on the daytime relationship. Even though respiration drives down $\Omega_{\text {Arag }}$ to $<\mathbf{2}$ during nighttime, net dissolution did not occur. See Supporting Information comparisons of NEC and NEP between 3-6 June and 10-14 June only during the common hours of day.

date (Table 5.3; Fig. 5-7). On average worldwide, reef flat NEC rates are 110-130 mmol $\mathrm{CaCO}_{3} \mathrm{~m}^{-2}$ day $^{-1}$ (Kinsey, 1985; Atkinson, 2011), and the highest diurnalaverage NEC rate previously measured in the field was $290 \mathrm{mmol} \mathrm{CaCO}_{3} \mathrm{~m}^{-2}$ day $^{-1}$ (Shamberger et al., 2011). Conversely, we measured diurnal-average NEC of 390 mmol $\mathrm{CaCO}_{3} \mathrm{~m}^{-2}$ day $^{-1}$ on the Dongsha reef flat. Although our measurements do not capture seasonal changes, the June NEC rate on Dongsha Atoll is uniquely high relative to all seasons on other coral reefs, and this is not explained by calcifier cover or coral community structure. The calcifier cover on the Dongsha reef flat (25\%) is similar to other reefs where NEC has been measured (Table 5.3; Fig. 5-7), and 

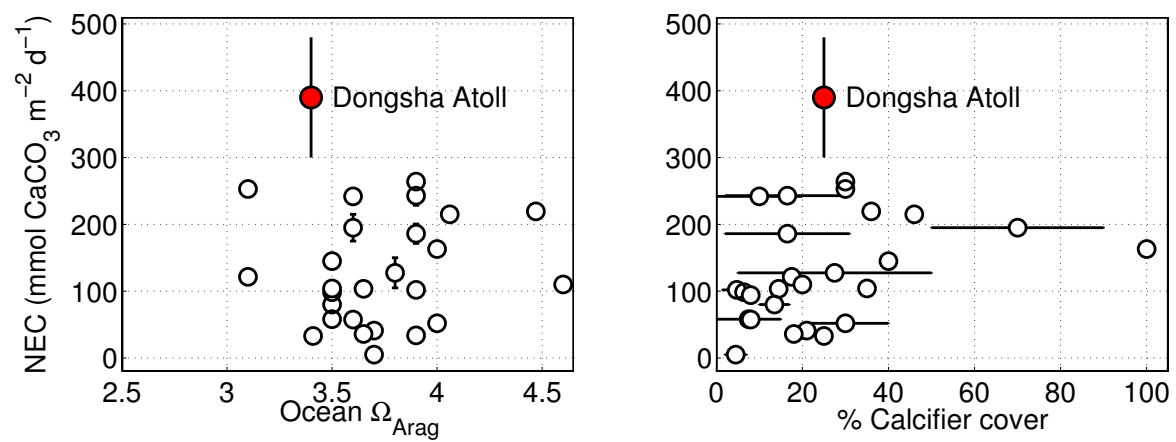

Figure 5-7: Global compilation of coral reef diurnal-average NEC rates plotted as functions of open-ocean $\Omega_{A r a g}$ and \% calcifier cover. Despite relatively low open-ocean $\Omega_{\text {Arag }}$ and comparable calcifier cover, NEC rates on Dongsha Atoll are significantly higher than those of all other reef systems studied to date. The data sources are tabulated in Table 3.

even though community structure data are not available for most metabolism studies, the relatively high abundance of fast-growing Acropora and Stylophora (Dullo, 2005) on Dongsha is similar to that of other reefs with lower NEC rates (Gattuso et al., 1996). Our findings challenge the paradigm that healthy coral reefs with favorable conditions for calcification have low algal cover and high open-ocean $\Omega_{\text {Arag }}$ (HoeghGuldberg et al., 2007). Rather, the benthic cover of fleshy algae on the Dongsha reef flat is relatively high (19\%) compared to most Indo-Pacific reefs (Bruno et al., 2009; Roff and Mumby, 2012), and the open-ocean $\Omega_{\text {Arag }}$ (3.4) in the northern SCS is near the minimum associated with most coral reefs today (Hoegh-Guldberg et al., 2007).

Daytime photosynthesis plays a key role in sustaining the rapid calcification on the Dongsha reef flat. The NEC rates are so high that they alone would drive daytime $\Omega_{\text {Arag }}$ toward saturation $\left(\Omega_{\text {Arag }}=1\right.$ ), and sometimes even below (Fig. 5-8). We observed the opposite response, however, with daytime $\Omega_{\text {Arag }}$ rising to greater than 5 on the reef at the same time of day as the most rapid NEC (Fig. 5-4 and Fig. 5-5). This paradox is explained by feedbacks between NEC, NEP, and the seawater carbonate system. Using our diurnal measurements of coupled TA and DIC changes, we isolated the effects of NEC and NEP on reef-water carbonate chemistry. Daytime $\mathrm{pCO}_{2}$ is elevated 2-fold under the combined effects of NEC and NEP compared to the isolated effect of NEP (Fig. 5-8). Yet the role of feedbacks between metabolism and carbonate chemistry is even more important for $\left[\mathrm{CO}_{3}^{2-}\right]$ and $\Omega_{\text {Arag. }}$. Our analysis 
indicates that daytime $\left[\mathrm{CO}_{3}^{2-}\right]$ is elevated 8-fold under the combined effects of NEC and NEP compared to the isolated effect of NEC (Fig. 5-8). NEP removes $\mathrm{CO}_{2}$ from reef water, preventing aragonite undersaturation $\left(\Omega_{\text {Arag }}<1\right)$ that would favor dissolution over calcification. Correlations between NEC and NEP are a common feature both within (Shaw et al., 2012; Albright et al., 2015; Koweek et al., 2015), and among (Gattuso et al., 1999), coral reef communities. Likewise, we observed this link on Dongsha Atoll, where it is maintained even at extremely high NEC and NEP rates (Fig. 5-6). This chemical feedback system - in which NEP produces $\mathrm{CO}_{3}^{2-}$ for calcification, and NEC feeds back by producing $\mathrm{CO}_{2}$ for photosynthesis thus highlights the important function of primary producers in modulating carbonate chemistry of coral reef waters.

Table 3. Global compilation of NEC and NEP rates measured on coral reefs.

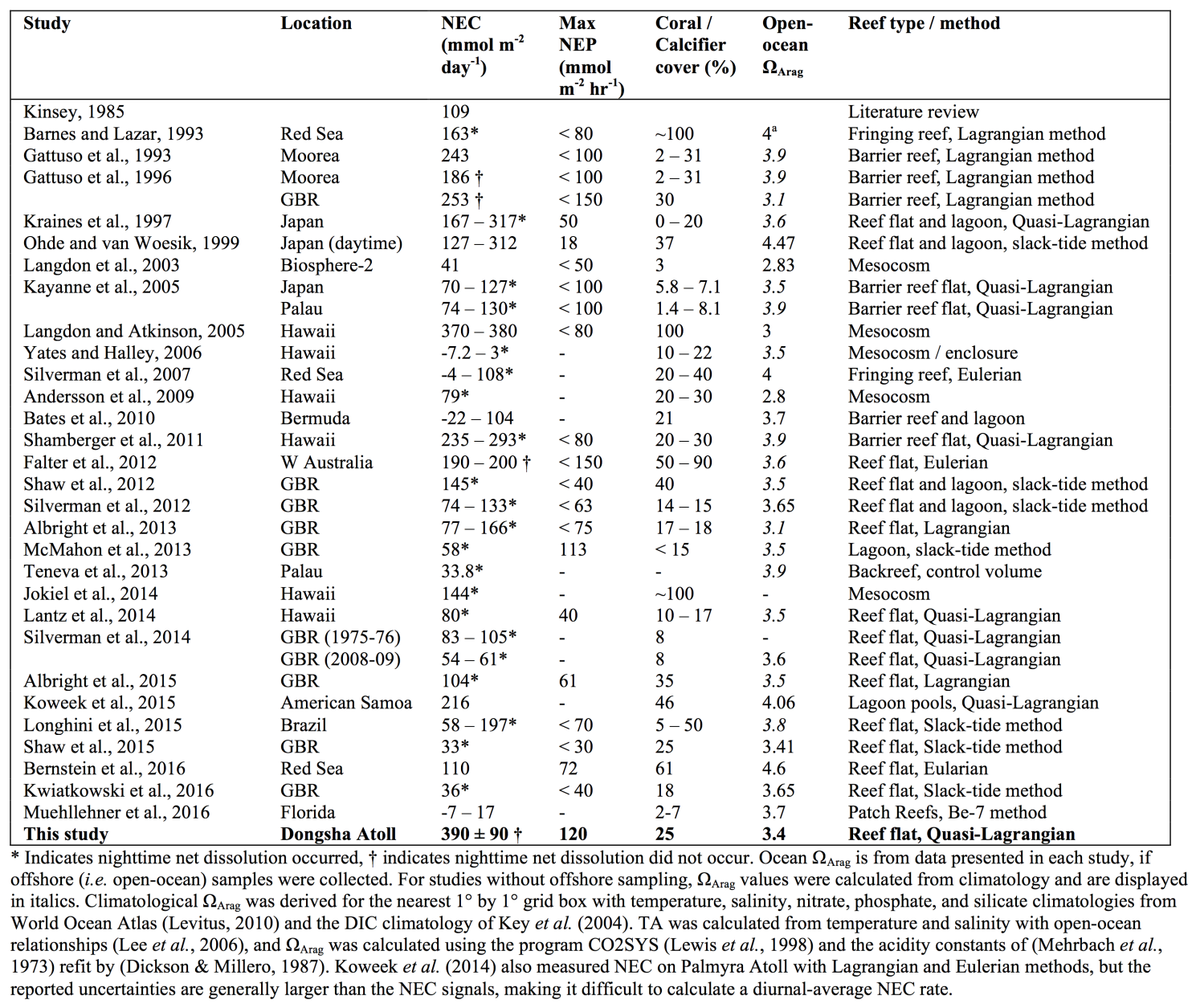


Community metabolism on Dongsha Atoll is also unique in that NEC increases exponentially, rather than linearly, with increasing NEP (Fig. 5-6). Related to this exponential relationship, we found that NEC decreases near zero at night but we found no significant net dissolution, which is rare among coral reef community metabolism studies (Table 3.3). In fact, the lack of nighttime dissolution is partly responsible for the uniquely high NEC rates on Dongsha Atoll (Fig. 5-6), as diurnal-average NEC on most other reefs is a balance between net calcification during the day and net dissolution at night. Because our data reveal only the net rates, we cannot determine if dissolution is entirely absent on the reef flat or nighttime dissolution is balanced by calcification. Identifying the factors that influence dissolution is thus a key question in understanding net $\mathrm{CaCO}_{3}$ production on Dongsha Atoll in particular, and in coral reef ecosystems generally. Future studies of coral reef community metabolism may benefit by combining our method for the net rates with techniques to quantify certain components of the metabolic signals, such as by using benthic flux chambers to measure dissolution in sediments.

\subsubsection{Effects of bleaching on community metabolism}

The role that the benthic community plays in modulating carbonate chemistry of reef water is further evident from changes in community metabolism associated with thermal stress. Anomalously high, or rapidly increasing, temperature can induce coral bleaching, the loss of the symbiotic algae from the coral holobiont Glynn (1993). Coral mortality following bleaching has been shown to reduce NEC rates (Kayanne et al., 2005), but no data exist to evaluate changes in community metabolism during a bleaching event. On Dongsha Atoll, reef-water temperature increased by $5{ }^{\circ} \mathrm{C}$ in less than three weeks during May 2014 (Fig. S1), and by the beginning of June most of the massive corals had bleached (Fig. S2). As reef waters cooled, bleaching subsided and corals regained their symbiotic algae populations by mid-June.

During the transient bleaching event, NEP decreased by $31 \mathrm{mmol} \mathrm{m}^{-2} \mathrm{hr}^{-1}$ and NEC decreased by $7 \mathrm{mmol} \mathrm{m}^{-2} \mathrm{hr}^{-1}$, a $40 \%$ reduction compared to the non-bleaching measurements (Fig. 5-4). Yet bleaching is not the only possible explanation for these 
(a)

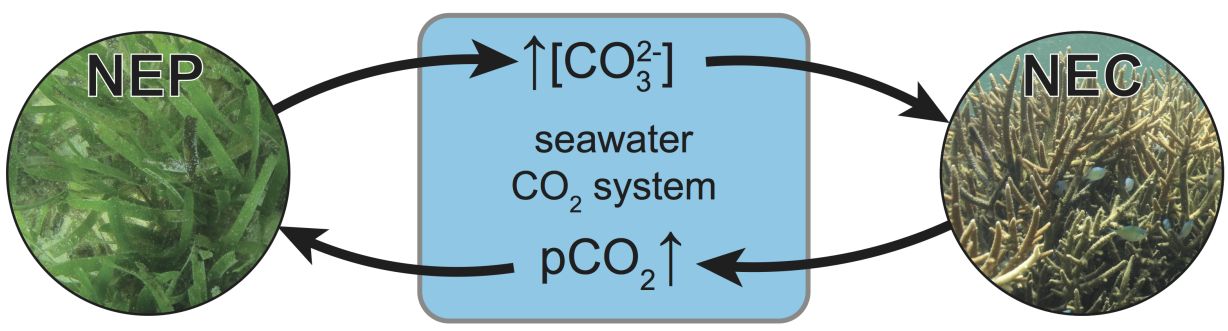

(b)
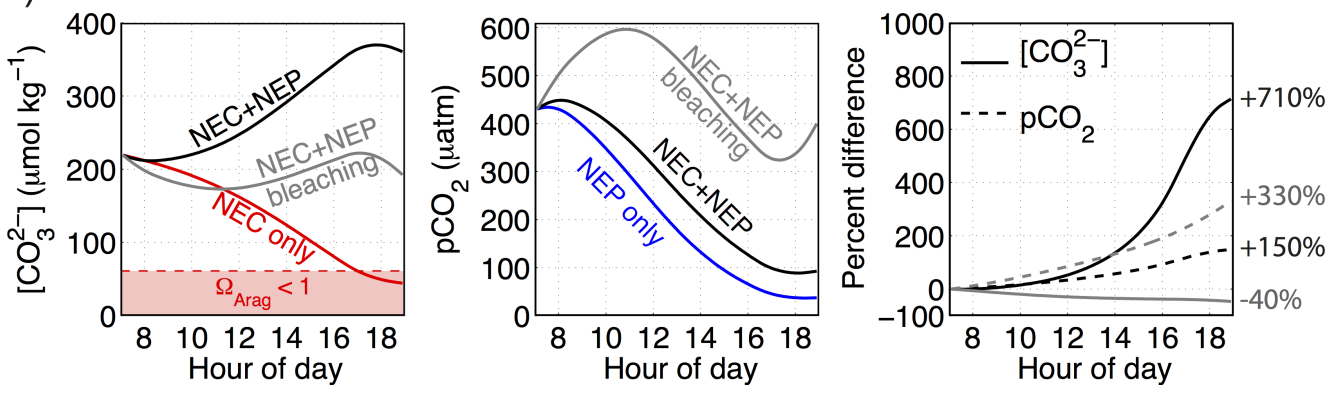

Figure 5-8: Conceptual model of feedbacks between community metabolism and carbonate chemistry. (a) NEP elevates $\left[\mathrm{CO}_{3}^{2-}\right]$, which is consumed by NEC. In turn, NEC elevates $\mathrm{CO}_{2}$, which is consumed by NEP. (b) Daytime profiles of reef-water $\left[\mathrm{CO}_{3}^{2-}\right]$ and $\mathrm{pCO}_{2}$ with isolated and combined effects of NEC and NEP. The calculations are performed for a 1-meter deep water column with residence time on the reef flat from dawn to dusk. Thus, the differences between curves show effects of community metabolism and are not dependent upon residence times. Black curves are calculated effects of NEC and NEP, red and blue curves show the expected $\left[\mathrm{CO}_{3}^{2-}\right]$ and $\mathrm{pCO}_{2}$ profiles with the isolated effects of NEC and NEP, respectively. The gray curves show the combined effects of NEC and NEP during the bleaching event (when NEC and NEP were reduced by 7 and $31 \mathrm{mmol} \mathrm{m}{ }^{-2} \mathrm{hr}^{-1}$, respectively). The isolated effect of $\mathrm{NEC}$ on $\left[\mathrm{CO}_{3}^{2-}\right]$ is so strong that it alone would drive $\Omega_{\text {Arag }}$ to undersaturation (light red shading). The right panel shows in black the percent difference between $\left[\mathrm{CO}_{3}^{2-}\right]$ based on $\mathrm{NEC}+\mathrm{NEP}$ compared to NEC alone; and for $\mathrm{pCO}_{2}$ based on NEC+NEP compared to NEP alone; and in gray the percent differences between bleaching and non-bleaching periods. The interaction between NEC and NEP is most important for $\left[\mathrm{CO}_{3}^{2-}\right]$, which is elevated approximately 8-fold by the effect of NEP, although $\mathrm{pCO}_{2}$ is still elevated more than $100 \%$ by the effect of NEC. Reduced metabolic rates during the bleaching event have the effect of reducing daytime $\left[\mathrm{CO}_{3}^{2-}\right]$ and increasing daytime $\mathrm{pCO}_{2}$.

changes. Rates of community metabolism are naturally variable and the percent differences between bleaching and non-bleaching periods that we observed are within the range of natural variability recorded on weekly timescales (e.g. Shamberger et al. (2011)). Further, mean current velocities during the bleaching event were approximately $50 \%$ lower compared to the non-bleaching period, and this could have affected the rates of community metabolism. Nevertheless, using multiple-regression analysis with our suite of physical measurements, we found that abiotic factors, including temperature, light, water depth, and current speed, were unable to account for the 
changes in metabolism between 3-6 June and 10-14 June (Figs S3-4), leaving bleaching as a likely driver. During the bleaching event, mean reef-water $\mathrm{pH}$ and $\Omega_{\text {Arag }}$ also declined on average by 0.2 and 0.8 units, respectively (Fig. 5-5). Reef-water chemistry is directly related to the rates of metabolism and to the residence time of water on the reef. Therefore, these changes in carbonate chemistry cannot be ascribed solely to changes in metabolism because the residence time of water on the reef was, on average, twice as long during the bleaching period relative to the non-bleaching period. To illustrate how the changes in metabolism alone would affect reef-water chemistry, we calculated the influence of metabolism on a parcel of water residing on the reef from dawn to dusk under the observed NEC and NEP rates during the bleaching and non-bleaching periods (Fig. 5-8). This analysis shows that bleachinginduced changes in metabolism, primarily the reductions in NEP, were sufficient to reduce maximum daytime $\left[\mathrm{CO}_{3}^{2-}\right]$ by more than $40 \%$. These effects - which occurred in less than two weeks and are comparable to changes predicted for the open ocean by the year 2100 (Feely et al., 2009) - further highlight that variations in community structure or health strongly modulate reef-water carbonate chemistry.

The tight relationship between NEC and NEP rates was maintained during bleaching and post-bleaching (Fig. 5-6), even though the rates were lower during the bleaching event (Fig. 5-4). Several possibilities exist to explain how thermal stress affects NEC and NEP rates together, without decoupling them. If photosynthesis by the symbiotic algae within coral colonies constitutes a significant proportion of the total NEP rate, then the expulsion of these algae from bleached coral colonies could decrease NEP directly. The simultaneous response of NEC may be due to some combination of increasing seawater $\mathrm{CO}_{2}$ concentrations and direct energetic stress imposed on corals by the loss of their symbionts (Cohen and Holcomb, 2009). Alternatively, symbiont photosynthesis may not contribute substantially to the NEP rates. If this is the case, then the bleaching event potentially reduced NEC directly by perturbing the coral-algal symbiosis, and/or NEP directly by thermal stress on seagrass or fleshy algae (Campbell et al., 2006). Because our metabolic rate data do not identify the relative contributions of various organisms, we cannot determine whether the link 
between NEC and NEP is established at the organismal level (i.e., the link is driven by the coral-algal symbiosis) or the community level (i.e., the link is driven by interactions between calcifiers and photosynthesizers and is mediated by the seawater carbonate system). Yet, whichever is the dominant mechanism, a reduction in one of the metabolic rates is clearly associated with a reduction in the other (Fig. 5-4 and Fig. 5-6), indicating that they are inextricably linked.

\subsubsection{Implications for coral reef resilience to ocean acidifica- tion and warming}

A worldwide search is underway to locate the coral reef ecosystems most likely to withstand the effects of $\mathrm{CO}_{2}$-driven climate change into the next century (Castillo et al., 2012; Karnauskas and Cohen, 2012; van Hooidonk et al., 2013; Shamberger et al., 2014; DeCarlo et al., 2015b). Our findings imply that anthropogenic $\mathrm{CO}_{2}$-driven changes in open-ocean chemistry will not necessarily translate directly to changes in reef-water chemistry. Decreases in open-ocean $\mathrm{pH}$ and $\Omega_{\text {Arag }}$ projected by the end of this century (0.3 and 1.5, respectively) (Feely et al., 2009) are comparable to the daytime elevation of $\mathrm{pH}$ and $\Omega_{\text {Arag }}$ driven by productivity on Dongsha Atoll. While ocean acidification poses a major threat to coral reef ecosystems, it will not be the sole driver of reef-water carbonate chemistry, nor will it affect all coral reefs equally. Feedbacks between community metabolism and reef-water carbonate chemistry may influence the sensitivity of coral reef ecosystems to acidification of the open ocean, and reefs with high rates of photosynthesis to remove $\mathrm{CO}_{2}$ from seawater may be the most likely to sustain conditions favorable for rapid calcification. Yet the capacity of benthic communities to modulate reef-water chemistry depends on community structure and health, which are sensitive to thermal stress. By the end of this century, temperatures on more than $80 \%$ of the world's reefs are projected to exceed coral

bleaching thresholds annually (van Hooidonk et al., 2013). Ocean warming therefore poses an inescapable threat to the metabolic performance of coral reef ecosystems, one that benthic communities cannot buffer. 


\section{Bibliography}

Albright, R., Benthuysen, J., Cantin, N., Caldeira, K., Anthony, K., 2015. Coral reef metabolism and carbon chemistry dynamics of a coral reef flat. Geophysical Research Letters 42 (10), 3980-3988.

Albright, R., Caldeira, L., Hosfelt, J., Kwiatkowski, L., Maclaren, J. K., Mason, B. M., Nebuchina, Y., Ninokawa, A., Pongratz, J., Ricke, K. L., Rivlin, T., Schneider, K., Sesboüé, M., Shamberger, K., Silverman, J., Wolfe, K., Zhu, K., Caldeira, K., 2016. Reversal of ocean acidification enhances net coral reef calcification. Nature $531,362-365$.

Albright, R., Langdon, C., Anthony, K. R. N., 2013. Dynamics of seawater carbonate chemistry, production, and calcification of a coral reef flat, Central Great Barrier Reef. Biogeosciences Discussions 10 (5), 7641-7676.

Andersson, A. J., Kuffner, I. B., Mackenzie, F. T., Jokiel, P. L., Rodgers, K. S., Tan, A., 2009. Net loss of CaCO 3 from coral reef communities due to human induced seawater acidification. Biogeosciences Discussions 6 (1), 2163-2182.

Andersson, A. J., Mackenzie, F. T., 2011. Ocean acidification: setting the record straight. Biogeosciences Discussions 8, 6161-6190.

Andersson, A. J., Yeakel, K. L., Bates, N. R., de Putron, S. J., 2014. Partial offsets in ocean acidification from changing coral reef biogeochemistry. Nature Climate Change 4 (1), 56-61.

Atkinson, M. J., 2011. Biogeochemistry of Nutrients. In: Dubinsky, Z., Stambler, N. (Eds.), Coral Reefs: An Ecosystem in Transition. Springer Netherlands, Dordrecht.

Barnes, D., Lazar, B., 1993. Metabolic performance of a shallow reef patch near Eilat on the Red Sea. Journal of Experimental Marine Biology and Ecology 174 (1), $1-13$.

Bates, N. R., Amat, A., Andersson, A. J., 2010. Feedbacks and responses of coral calcification on the Bermuda reef system to seasonal changes in biological processes and ocean acidification. Biogeosciences 7 (8), 2509-2530.

Bernstein, W. N., Hughen, K. A., Langdon, C., McCorkle, D. C., Lentz, S. J., 2016. Environmental controls on daytime net community calcification on a Red Sea reef flat. Coral Reefs 35 (2), 697-711.

Bruno, J. F., Sweatman, H., Precht, W. F., Selig, E. R., Schutte, V. G. W., 2009. Assessing evidence of phase shifts from coral to macroalgal dominance on coral reefs. Ecology 90 (6), 1478-1484.

Campbell, S. J., McKenzie, L. J., Kerville, S. P., 2006. Photosynthetic responses of seven tropical seagrasses to elevated seawater temperature. Journal of Experimental Marine Biology and Ecology 330 (2), 455-468. 
Castillo, K. D., Ries, J. B., Weiss, J. M., Lima, F. P., 2012. Decline of forereef corals in response to recent warming linked to history of thermal exposure. Nature Climate Change 2, 756-760.

Cohen, A. L., Holcomb, M., 2009. Why corals care about ocean acidification: uncovering the mechanism. Oceanography 22 (4), 118-127.

Costanza, R., de Groot, R., Sutton, P., van der Ploeg, S., Anderson, S. J., Kubiszewski, I., Farber, S., Turner, R. K., 2014. Changes in the global value of ecosystem services. Global Environmental Change 26, 152-158.

Cyronak, T., Schulz, K. G., Santos, I. R., Eyre, B. D., 2014. Enhanced acidification of global coral reefs driven by regional biogeochemical feedbacks. Geophysical Research Letters 41 (15), 5538-5546.

DeCarlo, T. M., Cohen, A. L., Barkley, H. C., Cobban, Q., Young, C., Shamberger, K. E., Brainard, R. E., Golbuu, Y., 2015a. Coral macrobioerosion is accelerated by ocean acidification and nutrients. Geology 43 (1), 7-10.

DeCarlo, T. M., Karnauskas, K. B., Davis, K. A., Wong, G. T., 2015b. Climate modulates internal wave activity in the Northern South China Sea. Geophysical Research Letters 42 (3), 831-838.

Dickson, A. G., Millero, F. J., 1987. A comparison of the equilibrium constants for the dissociation of carbonic acid in seawater media. Deep Sea Research Part A. Oceanographic Research Papers 34 (10), 1733-1743.

Doney, S. C., Fabry, V. J., Feely, R. A., Kleypas, J. A., 2009. Ocean acidification: the other CO2 problem. Marine Science 1.

Dullo, W.-C., 2005. Coral growth and reef growth: a brief review. Facies 51 (1-4), $33-48$

Falter, J. L., Lowe, R. J., Atkinson, M. J., Cuet, P., 2012. Seasonal coupling and de-coupling of net calcification rates from coral reef metabolism and carbonate chemistry at Ningaloo Reef, Western Australia. Journal of Geophysical Research 117 (C5), C05003.

Falter, J. L., Lowe, R. J., Atkinson, M. J., Monismith, S. G., Schar, D. W., 2008. Continuous measurements of net production over a shallow reef community using a modified Eulerian approach. Journal of Geophysical Research 113 (C7), C07035.

Feely, R. A., Doney, S. C., Cooley, S. R., 2009. Ocean acidification: present conditions and future changes in a high-CO2 world. Oceanography 22 (4), 37-47.

Garcia, H. E., Gordon, L. I., 1992. Oxygen solubility in seawater: Better fitting equations. Limnology and Oceanography 37 (6), 1307-1312. 
Gattuso, J. P., Allemand, D., Frankignoulle, M., 1999. Photosynthesis and calcification at cellular, organismal and community levels in coral reefs: a review on interactions and control by carbonate chemistry. American Zoologist 39 (1), 160183.

Gattuso, J.-P., Pichon, M., Delesalle, B., Canon, C., Frankignoulle, M., 1996. Carbon fluxes in coral reefs. I. Lagrangian measurement of community metabolism and resulting air-sea CO2 disequilibrium. Marine Ecology Progress Series 145, 109-121.

Gattuso, J.-P., Pichon, M., Delesalle, B., Frankignoulle, M., jan 1993. Community metabolism and air-sea CO2 fluxes in a coral reef ecosystem (Moorea, French Polynesia). Marine Ecology Progress Series 96, 259-267.

Gawarkiewicz, G., Wang, J., Caruso, M., Ramp, S. R., Brink, K. H., Bahr, F., 2004. Shelfbreak circulation and thermohaline structure in the northern south China Sea-contrasting spring conditions in 2000 and 2001. IEEE Journal of Oceanic Engineering 29 (4), 1131-1143.

Glynn, P. W., 1993. Coral reef bleaching: ecological perspectives. Coral Reefs 12 (1), $1-17$.

Golbuu, Y., Victor, S., Penland, L., Idip, D., Emaurois, C., Okaji, K., Yukihira, H., Iwase, A., van Woesik, R., 2007. Palau's coral reefs show differential habitat recovery following the 1998-bleaching event. Coral Reefs 26 (2), 319-332.

Guo, X., Wong, G. T., 2015. Carbonate chemistry in the northern South China Sea shelf-sea in June 2010. Deep Sea Research Part II: Topical Studies in Oceanography $117,119-130$.

Ho, D. T., Law, C. S., Smith, M. J., Schlosser, P., Harvey, M., Hill, P., 2006. Measurements of air-sea gas exchange at high wind speeds in the Southern Ocean: Implications for global parameterizations. Geophysical Research Letters 33 (16), L16611.

Hoegh-Guldberg, O., Mumby, P. J., Hooten, A. J., Steneck, R. S., Greenfield, P., Gomez, E., Harvell, C. D., Sale, P. F., Edwards, A. J., Caldeira, K., 2007. Coral reefs under rapid climate change and ocean acidification. Science 318 (5857), 17371742 .

Hönisch, B., Ridgwell, A., Schmidt, D. N., Thomas, E., Gibbs, S. J., Sluijs, A., Zeebe, R., Kump, L., Martindale, R. C., Greene, S. E., 2012. The geological record of ocean acidification. Science 335 (6072), 1058-1063.

Johnson, H. K., 1999. Simple expressions for correcting wind speed data for elevation. Coastal Engineering 36 (3), 263-269.

Jokiel, P. L., Jury, C. P., Rodgers, K. S., 2014. Coral-algae metabolism and diurnal changes in the CO2-carbonate system of bulk sea water. PeerJ 2, e378. 
Karnauskas, K. B., Cohen, A. L., 2012. Equatorial refuge amid tropical warming. Nature Climate Change 2, 530-534.

Kayanne, H., Hata, H., Kudo, S., Yamano, H., Watanabe, A., Ikeda, Y., Nozaki, K., Kato, K., Negishi, A., Saito, H., 2005. Seasonal and bleaching-induced changes in coral reef metabolism and CO 2 flux. Global Biogeochemical Cycles 19 (3), GB3015.

Kinsey, D. D., 1985. Metabolism, calcification and carbon production. I. System level studies.

Kleypas, J. A., Anthony, K. R. N., Gattuso, J.-P., 2011. Coral reefs modify their seawater carbon chemistry - case study from a barrier reef (Moorea, French Polynesia). Global Change Biology 17 (12), 3667-3678.

Kline, D. I., Teneva, L., Hauri, C., Schneider, K., Miard, T., Chai, A., Marker, M., Dunbar, R., Caldeira, K., Lazar, B., Rivlin, T., Mitchell, B. G., Dove, S., HoeghGuldberg, O., 2015. Six Month In Situ High-Resolution Carbonate Chemistry and Temperature Study on a Coral Reef Flat Reveals Asynchronous pH and Temperature Anomalies. PLOS ONE 10 (6), e0127648.

Kohler, K. E., Gill, S. M., 2006. Coral Point Count with Excel extensions (CPCe): A Visual Basic program for the determination of coral and substrate coverage using random point count methodology. Computers \& Geosciences 32 (9), 1259-1269.

Koweek, D., Dunbar, R. B., Rogers, J. S., Williams, G. J., Price, N., Mucciarone, D., Teneva, L., 2014. Environmental and ecological controls of coral community metabolism on Palmyra Atoll. Coral Reefs 34 (1), 339-351.

Koweek, D. A., Dunbar, R. B., Monismith, S. G., Mucciarone, D. A., Woodson, C. B., Samuel, L., 2015. High-resolution physical and biogeochemical variability from a shallow back reef on Ofu, American Samoa: an end-member perspective. Coral Reefs 34 (3), 979-991.

Kraines, S., Suzuki, Y., Omori, T., 1997. Carbonate dynamics of the coral reef system at Bora Bay, Miyako Island. Mar. Ecol. Prog. Ser. 156, 1-16.

Kwiatkowski, L., Albright, R., Hosfelt, J., Nebuchina, Y., Ninokawa, A., Rivlin, T., Sesboüé, M., Wolfe, K., Caldeira, K., 2016. Interannual stability of organic to inorganic carbon production on a coral atoll. Geophysical Research Letters 43 (8), 3880-3888.

Langdon, C., Atkinson, M. J., 2005. Effect of elevated pCO2 on photosynthesis and calcification of corals and interactions with seasonal change in temperature/irradiance and nutrient enrichment. Journal of Geophysical Research 110 (C9), C09S07.

Langdon, C., Broecker, W. S., Hammond, D. E., Glenn, E., Fitzsimmons, K., Nelson, S. G., Peng, T.-H., Hajdas, I., Bonani, G., 2003. Effect of elevated CO 2 on the 
community metabolism of an experimental coral reef. Global Biogeochemical Cycles $17(1), 1-14$.

Langdon, C., Gattuso, J., Andersson, A., 2010. Measurements of calcification and dissolution of benthic organisms and communities. In: Riebesell, U., Fabry, V., Hansson, L., Gattuso, J. (Eds.), Guide to best practices for ocean acidification research and data reporting. Publications Office of the European Union, Luxembourg.

Lantz, C. A., Atkinson, M. J., Winn, C. W., Kahng, S. E., 2014. Dissolved inorganic carbon and total alkalinity of a Hawaiian fringing reef: chemical techniques for monitoring the effects of ocean acidification on coral reefs. Coral Reefs 33 (1), $105-115$.

Lee, K., Tong, L. T., Millero, F. J., Sabine, C. L., Dickson, A. G., Goyet, C., Park, G., Wanninkhof, R., Feely, R. A., Key, R. M., 2006. Global relationships of total alkalinity with salinity and temperature in surface waters of the world's oceans. Geophysical Research Letters 33 (19), L19605.

Lewis, E., Wallace, D., Allison, L. J., 1998. Program developed for CO2 system calculations. Tech. rep.

Longhini, C., Souza, M., Silva, A., 2015. Net ecosystem production, calcification and CO2 fluxes on a reef flat in Northeastern Brazil. Estuarine, Coastal and Shelf Science 166, 13-23.

McDougall, T., Feistel, R., Millero, F., 2009. The International Thermodynamic Equation Of Seawater 2010 (TEOS-10): Calculation and Use of Thermodynamic Properties. Tech. rep.

McMahon, A., Santos, I. R., Cyronak, T., Eyre, B. D., 2013. Hysteresis between coral reef calcification and the seawater aragonite saturation state. Geophysical Research Letters 40 (17), 4675-4679.

Mehrbach, C., 1973. Measurement of the apparent dissociation constants of carbonic acid in seawater at atmospheric pressure.

Muehllehner, N., Langdon, C., Venti, A., Kadko, D., 2016. Dynamics of carbonate chemistry, production, and calcification of the Florida Reef Tract (2009-2010): Evidence for seasonal dissolution. Global Biogeochemical Cycles 30, 661-688.

Odum, H., Odum, E., 1955. Trophic structure and productivity of a windward coral reef community on Eniwetok Atoll. Ecological Monographs 25 (3), 291-320.

Ohde, S., van Woesik, R., 1999. Carbon dioxide flux and metabolic processes of a coral reef, Okinawa. Bulletin of Marine Science 65 (2), 559-576.

Roff, G., Mumby, P. J., 2012. Global disparity in the resilience of coral reefs. Trends in ecology \& evolution 27, 404-413. 
Sabine, C. L., Feely, R. A., Gruber, N., Key, R. M., Lee, K., Bullister, J. L., Wanninkhof, R., Wong, C., Wallace, D. W. R., Tilbrook, B., 2004. The oceanic sink for anthropogenic CO2. Science 305 (5682), 367-371.

Sarmiento, J., Gruber, N., 2006. Ocean Biogeochemical Dynamics. Princeton University Press, Princeton, NJ.

Shamberger, K. E., Cohen, A. L., Golbuu, Y., McCorkle, D. C., Lentz, S. J., Barkley, H. C., 2014. Diverse coral communities in naturally acidified waters of a Western Pacific reef. Geophys. Res. Lett. 41 (2), 499-504.

Shamberger, K. E. F., Feely, R. A., Sabine, C. L., Atkinson, M. J., DeCarlo, E. H., Mackenzie, F. T., Drupp, P. S., Butterfield, D. A., 2011. Calcification and organic production on a Hawaiian coral reef. Marine Chemistry 127 (1), 64-75.

Shaw, E. C., McNeil, B. I., Tilbrook, B., 2012. Impacts of ocean acidification in naturally variable coral reef flat ecosystems. Journal of Geophysical Research: Oceans 117 (C3), C03038.

Shaw, E. C., Phinn, S. R., Tilbrook, B., Steven, A., 2014. Comparability of slack water and lagrangian flow respirometry methods for community metabolic measurements. PloS one 9 (11), e112161.

Shaw, E. C., Phinn, S. R., Tilbrook, B., Steven, A., 2015. Natural in situ relationships suggest coral reef calcium carbonate production will decline with ocean acidification. Limnology and Oceanography 00, 1-12.

Shaw, P. T., Chao, S. Y., 1994. Surface circulation in the South China Sea. Deep Sea Research Part I: Oceanographic Research Papers 41 (11-12), 1663-1683.

Shih, P.-Y., Arumugam, D., Shyue, S.-W., 2011. Bathymetric Lidar Survey Of Penghu Islands and Dongsha Atoll. Sea Technology 52 (11), 42-45.

Silverman, J., Kline, D. I., Johnson, L., Rivlin, T., Schneider, K., Erez, J., Lazar, B., Caldeira, K., 2012. Carbon turnover rates in the One Tree Island reef: A 40âĂRyear perspective. Journal of Geophysical Research: Biogeosciences 117 (G3), G03023.

Silverman, J., Lazar, B., Erez, J., 2007. Effect of aragonite saturation, temperature, and nutrients on the community calcification rate of a coral reef. Journal of Geophysical Research: Oceans (1978-2012) 112 (C5), C05004.

Silverman, J., Schneider, K., Kline, D., Rivlin, T., Rivlin, A., Hamylton, S., Lazar, B., Erez, J., Caldeira, K., 2014. Community calcification in Lizard Island, Great Barrier Reef: A 33year perspective. Geochimica et Cosmochimica Acta 144, 72-81.

Smith, J. E., Price, N. N., Nelson, C. E., Haas, A. F., 2013. Coupled changes in oxygen concentration and $\mathrm{pH}$ caused by metabolism of benthic coral reef organisms. Marine Biology 160 (9), 2437-2447. 
Teneva, L., Dunbar, R. B., Mucciarone, D. A., Dunckley, J. F., Koseff, J. R., 2013. High-resolution carbon budgets on a Palau back-reef modulated by interactions between hydrodynamics and reef metabolism. Limnology and Oceanography 58 (5), 1851-1870.

van Hooidonk, R., Maynard, J. A., Planes, S., 2013. Temporary refugia for coral reefs in a warming world. Nature Climate Change 3, 508-511.

Wanninkhof, R., 1992. Relationship between wind speed and gas exchange over the ocean. Journal of Geophysical Research 97 (C5), 7373.

Weiss, R. F., 1974. Carbon dioxide in water and seawater: the solubility of a non-ideal gas. Marine Chemistry 2 (3), 203-215.

Wong, G. T. F., Ku, T.-L., Mulholland, M., Tseng, C.-M., Wang, D.-P., 2007. The SouthEast Asian time-series study (SEATS) and the biogeochemistry of the South China Sea - an overview. Deep Sea Research Part II: Topical Studies in Oceanography 54 (14), 1434-1447.

Yates, K. K., Halley, R. B., 2006. CO3 concentration and pCO2 thresholds for calcification and dissolution on the Molokai reef flat, Hawaii. Biogeosciences 3 (3), 357-369.

Yeakel, K. L., Andersson, A. J., Bates, N. R., Noyes, T. J., Collins, A., Garley, R., 2015. Shifts in coral reef biogeochemistry and resulting acidification linked to offshore productivity. Proceedings of the National Academy of Sciences of the United States of America 112 (47), 14512-7.

Zeebe, R. E., Ridgwell, A., Zachos, J. C., 2016. Anthropogenic carbon release rate unprecedented during the past 66 million years. Nature Geoscience 9 (4), 325-329.

\subsection{Supporting Information}

\subsubsection{Coral bleaching in response to thermal stress}

We observed mass coral bleaching on the Dongsha Atoll reef flat in response to thermal stress during May and June 2014. From mid-April to early May 2014, daily mean reef flat temperatures remained between $25^{\circ} \mathrm{C}$ and $27^{\circ} \mathrm{C}$, but increased steadily from 25.5 ${ }^{\circ} \mathrm{C}$ on 9 May to exceed $31{ }^{\circ} \mathrm{C}$ by 26 May, sparking widespread bleaching of massive corals (Fig. S1). Temperature decreased to $29{ }^{\circ} \mathrm{C}$ by 10 June, and the corals rapidly regained their pigmentation. 


\subsubsection{Oxygen-based NEP rate estimates}

In addition to the dissolved inorganic carbon (DIC)-based NEP rates presented in the main text, we calculated NEP using dissolved $\mathrm{O}_{2}$ measurements. The $\mathrm{O}_{2}$-based NEP equation is:

$$
\mathrm{NEP}=-\mathrm{PQ} \frac{\mathrm{O}_{2 \text { saturation }}-\mathrm{O}_{2 E 5}}{\tau} \bar{h}+\mathrm{F}_{\mathrm{O}_{2}}
$$

where NEP is in units of mmol organic carbon $\mathrm{m}^{-2} \mathrm{hr}^{-1}, \mathrm{O}_{2}$ is in $\mathrm{mmol} \mathrm{m}^{-3}$, $\mathrm{PQ}$ is the photosynthetic quotient (moles of oxygen to moles of carbon fixed via photosynthesis and released via respiration) estimated as $1.05 \pm 0.1$ following Falter et al. (2008), $\bar{h}$ is the time-averaged depth of the water parcel, $\tau$ is the residence time of a parcel of water on the reef $(\mathrm{hr})$, and $\mathrm{F}_{\mathrm{O}_{2}}$ is the $\mathrm{O}_{2}$ air-sea gas exchange flux $\left(\mathrm{mmol} \mathrm{O}_{2} \mathrm{~m}^{-2} \mathrm{hr}^{-1}\right)$. The initial $\mathrm{O}_{2}$ concentration was assumed to be equal to $100 \%$ saturation with the atmosphere, and was calculated following Garcia and Gordon (1992) using the temperature and salinity measured at station E2. The gas exchange flux was calculated as:

$$
\mathrm{F}_{\mathrm{O}_{2}}=\mathrm{k}_{\mathrm{O}_{2}}\left(\mathrm{O}_{2 E 5}-\mathrm{O}_{2 \text { saturation }}\right) / 2
$$

where $\mathrm{k}_{\mathrm{O}_{2}}$ is the $\mathrm{O}_{2}$ gas transfer velocity $\left(\mathrm{m} \mathrm{hr}^{-1}\right)$ and $\mathrm{O}_{2 E 5}$ is the measured oxygen concentration in water at E5. The factor 2 is used to approximate the average gas flux during reef flat residence time. We assume that as water initially flows onto the reef, the oxygen concentration is at saturation and thus $\mathrm{F}_{\mathrm{O}_{2}}$ is zero, whereas $\mathrm{O}_{2 E 5}$ represents the end-point of the residence time and presumably the greatest difference from saturation. Thus, assuming oxygen concentration changes linearly in time as a water parcel traverses the reef flat, $\mathrm{F}_{\mathrm{O}_{2}}=\mathrm{k}_{\mathrm{O}_{2}}\left(\mathrm{O}_{2 E 5}-\mathrm{O}_{2 \text { saturation }}\right) / 2$ approximates the average $\mathrm{F}_{\mathrm{O}_{2}}$ during the reef flat residence time. $\mathrm{k}_{\mathrm{O}_{2}}$ is calculated following Sarmiento and Gruber (2006):

$$
\mathrm{k}_{\mathrm{O}_{2}}=\mathrm{k}_{600}\left(\frac{S c_{\mathrm{O}_{2}}}{S c_{600}}\right)^{-0.5}
$$

where $\mathrm{k}_{600}$ is the piston velocity of $\mathrm{CO}_{2}$ in freshwater at $20{ }^{\circ} \mathrm{C}$ calculated with the 
parameterization of Ho et al. (2006) based on wind speed measured at $6 \mathrm{~m}$ mean altitude on a scaffolding tower constructed at station E5 and adjusted to $10 \mathrm{~m}$ altitude wind speed following the calculations of Johnson (1999), and $S c_{\mathrm{O}_{2}}$ is the Schmidt number of oxygen calculated assuming salinity of 35 and with the temperature dependent formula of Sarmiento and Gruber (2006). Wind speed measurements are averaged over the reef flat residence time of each water parcel. We estimated the uncertainty of $\mathrm{O}_{2}$-based NEP by propagating uncertainty of PQ $( \pm 0.1), \mathrm{O}_{2}$ measurement uncertainty from our Onset U026 logger $\left( \pm 6.25 \mathrm{mmol} \mathrm{m}^{-3}\right.$ for $<250 \mathrm{mmol}$ $\mathrm{m}^{-3}$ and $\pm 15.6 \mathrm{mmol} \mathrm{m}^{-3}$ for $>250 \mathrm{mmol} \mathrm{m}^{-3}$ ), uncertainty in $\mathrm{k}_{600}$ (Ho et al., 2006), and uncertainty in $\tau$ (following Methods section in main text). Our coupled measurements of $\mathrm{O}_{2}$ and wind speed at E5 spanned 10-12 June, corresponding with part of our second RAS deployment. During this time, $\mathrm{O}_{2}$-based and DIC-based NEP rates were in close agreement and followed similar diurnal patterns (Fig. S2), giving us confidence in the accuracy of our longer DIC-based NEP time series.

\subsubsection{Effects of coral bleaching on NEC and NEP rates}

We evaluated the response of NEC and NEP to the coral bleaching event by comparing our metabolic rates measurements between 3-6 June (bleached) and 10-14 June (postbleaching). However, this comparison must account for the different hours of day sampled, and potentially any differences in physical variables, between the two time periods. We found that for the hours of day in common between our 3-6 June and our 10-14 June measurements, NEC and NEP rates were significantly lower during the bleaching event (Results section in main text). Here, we test if any abiotic factors contributed to the differences in metabolism using our suite of physical measurements (Fig. S3). First, we found that NEC and NEP were correlated with temperature and light, and that for any temperature or light level the rates were lower during bleaching (Fig. S4). Next, we performed multiple linear regressions between the metabolic rates and physical factors, and including bleaching as a categorical variable. These tests are not intended to proscribe the direct effects of abiotic factors on NEC and NEP rates because the correlations are potentially artifacts of coherent diurnal cycles. Rather, 
this analysis evaluates the potential for differences in abiotic factors to account for the changes in NEC and NEP during- and post-bleaching event. The best-fit equations are reported in Table S1. These analyses show that our measured abiotic factors cannot explain the differences in NEC and NEP between 3-6 June and 10-14 June, leaving bleaching as a significant effect on the metabolic rates (i.e. the bleaching term in each equation is significantly different from zero).

\subsubsection{NEC and NEP during- and post-bleaching}

We found a significant relationship between NEC and NEP, with no significant effect of bleaching on this relationship (Results section in main text). Here, we evaluate this relationship during the hours of day common to both our during- and post-bleaching measurements. The common hours of day are from 06:00 to 12:30 based on the midpoints of residence times, and from 05:00 to 16:00 based on the full residence times (Fig. S5). We evaluated the relationship between NEC and NEP using only these subsets of overlapping data, from 06:00 to 12:30 (Fig. S6) and from 05:00 to 16:00 (Fig. S7). Linear regression between NEC and NEP produced the following fits:

$$
\begin{aligned}
& (06: 00 \text { to } 12: 30) \mathrm{NEC}=13(3)+0.17(0.05) \mathrm{NEP}-1(4) \mathrm{B} \\
& (05: 00 \text { to } 16: 00) \mathrm{NEC}=14(2)+0.23(0.04) \mathrm{NEP}-2(4) \mathrm{B}
\end{aligned}
$$

where numbers in parentheses indicate $\pm 2 \sigma, \mathrm{NEC}$ and NEP are in units of mmol $\mathrm{CaCO}_{3} \mathrm{~m}^{-2} \mathrm{hr}^{-1}$ and mmol $\mathrm{C} \mathrm{m}^{-2} \mathrm{hr}^{-1}$ respectively, and " $\mathrm{B}$ " = 1 during the transient bleaching event and 0 otherwise. In both cases, the bleaching term is not significantly different from zero, meaning that there were no detectable changes in the relationship between NEC and NEP during- and post-bleaching. 
Table S1. Muliple-regression coefficients for NEC and NEP as functions of abiotic factors.

\begin{tabular}{|l|lllcccc|}
\hline & Intercept & PAR $^{\mathrm{a}}$ & Temperature & $\begin{array}{l}\text { Current } \\
\text { speed }\end{array}$ & $\begin{array}{l}\text { Water } \\
\text { depth }\end{array}$ & $\begin{array}{l}\text { Coral } \\
\text { bleaching }\end{array}$ & $\mathrm{r}^{2}$ \\
\hline NEC $^{\mathrm{b}}$ & $-60 \pm 70$ & $15 \pm 7$ & $2 \pm 2$ & - & - & $-12 \pm 5$ & 0.58 \\
& $-110 \pm 80$ & $14 \pm 7$ & $4 \pm 3$ & $30 \pm 30$ & - & $-8 \pm 5$ & 0.62 \\
& $-40 \pm 50$ & $24 \pm 5$ & $2 \pm 2$ & $50 \pm 20$ & $-20 \pm 5$ & $-6 \pm 4$ & 0.84 \\
\hline NEP & $-400 \pm 200$ & $80 \pm 30$ & $13 \pm 8$ & - & - & $-40 \pm 10$ & 0.79 \\
& $-400 \pm 300$ & $80 \pm 30$ & $13 \pm 9$ & $8 \pm 70$ & - & $-40 \pm 20$ & 0.79 \\
& $-300 \pm 200$ & $100 \pm 30$ & $9 \pm 8$ & $30 \pm 70$ & $-40 \pm 20$ & $-40 \pm 10$ & 0.84 \\
\hline
\end{tabular}

Notes: Values indicate coefficient terms $\pm 2 \sigma, \mathrm{NEC}$ and NEP are in units of $\mathrm{mmol} \mathrm{CaCO}_{3} \mathrm{~m}^{-2} \mathrm{hr}^{-1}$ and $\mathrm{mmol} \mathrm{C} \mathrm{m}^{-2} \mathrm{hr}^{-1}$ respectively, PAR is in units of

$\mu \mathrm{mol}$ photons $\mathrm{m}^{-2} \mathrm{~s}^{-1}$, temperature is in ${ }^{\circ} \mathrm{C}$, current speed is in $\mathrm{m} \mathrm{s}^{-1}$, water depth is in $\mathrm{m}$, and "Coral bleaching" $=1$ during the transient bleaching event and 0 otherwise. For all physical parameters, values were calculated as the mean of measurements during the residence time of each water parcel (i.e. averaged over the same time as represented by each metabolic rate measurement). All equations are significant at the 0.01 level.

${ }^{a}$ PAR term is $\tan ^{-1}(\mathrm{PAR} / 370)$ for NEC and $\tan ^{-1}(\mathrm{PAR} / 690)$ for NEP.

${ }^{b}$ For example, the equation for the first NEC row is: NEC $=-60+24 * \tan ^{-1}(\mathrm{PAR} / 370)+2 *$ temperature -12 during bleaching
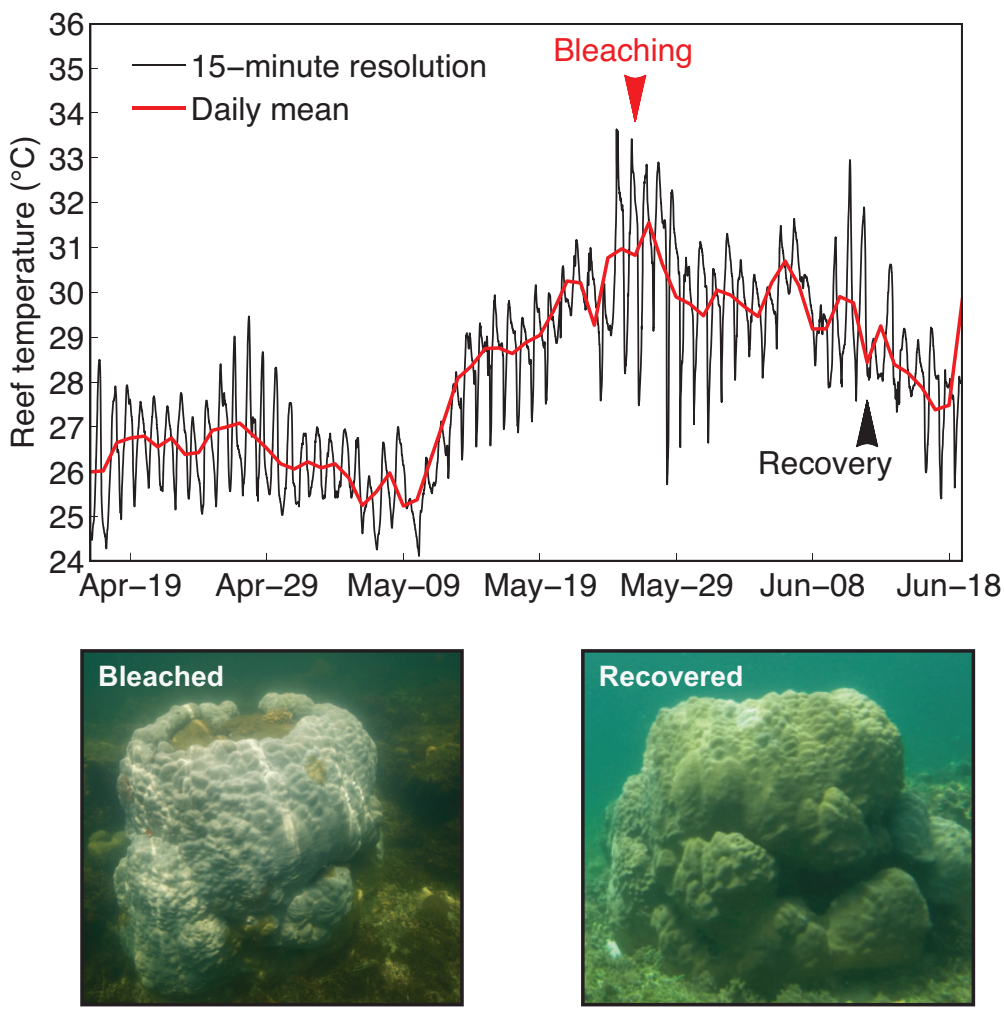

Fig. S1. Reef flat temperatures during April-June 2014. Temperatures rose on average 5-6 ${ }^{\circ} \mathrm{C}$ between early to late May, initiating coral bleaching. The corals recovered by mid-June as temperatures decreased. The photographs show the same massive Porites colony bleached white and recovered (pigmented) 2 weeks later. 


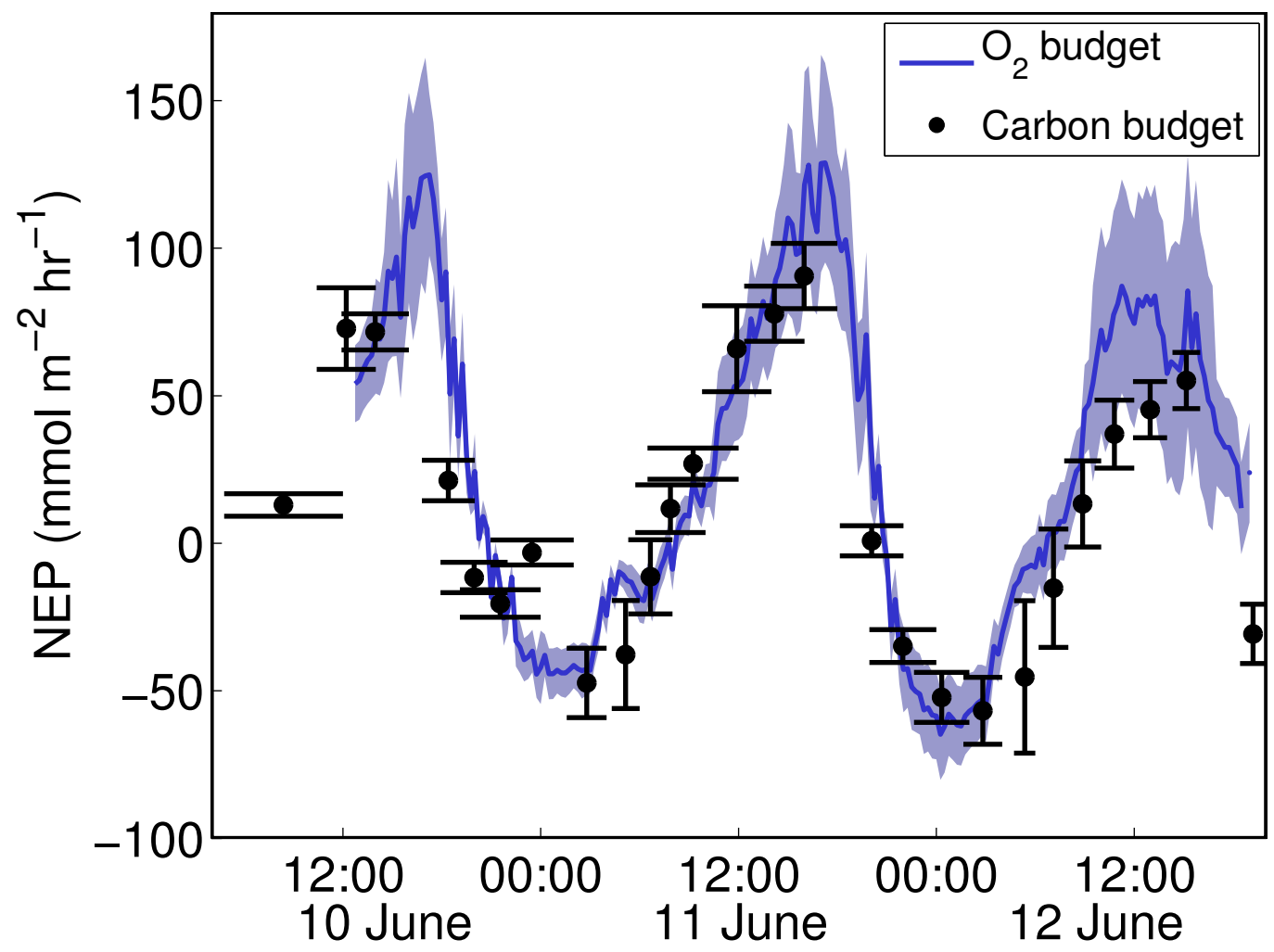

Fig. S2. Net Ecosystem Productivity (NEP) based on oxygen (blue) and carbon (black) budgets are in close agreement. Light blue shading represents $95 \%$ confidence interval of oxygen NEP estimates, and black error bars represent $1 \sigma$ of carbon NEP estimates. Carbon budget data are plotted on the time axis as the mid-point between the sampling time and the time when the water parcel traversed the reef crest, and the horizontal error bars represent the residence times (i.e. the left end-point is when the water parcel crossed the reef crest and the right end-point is the reef flat sampling time). 


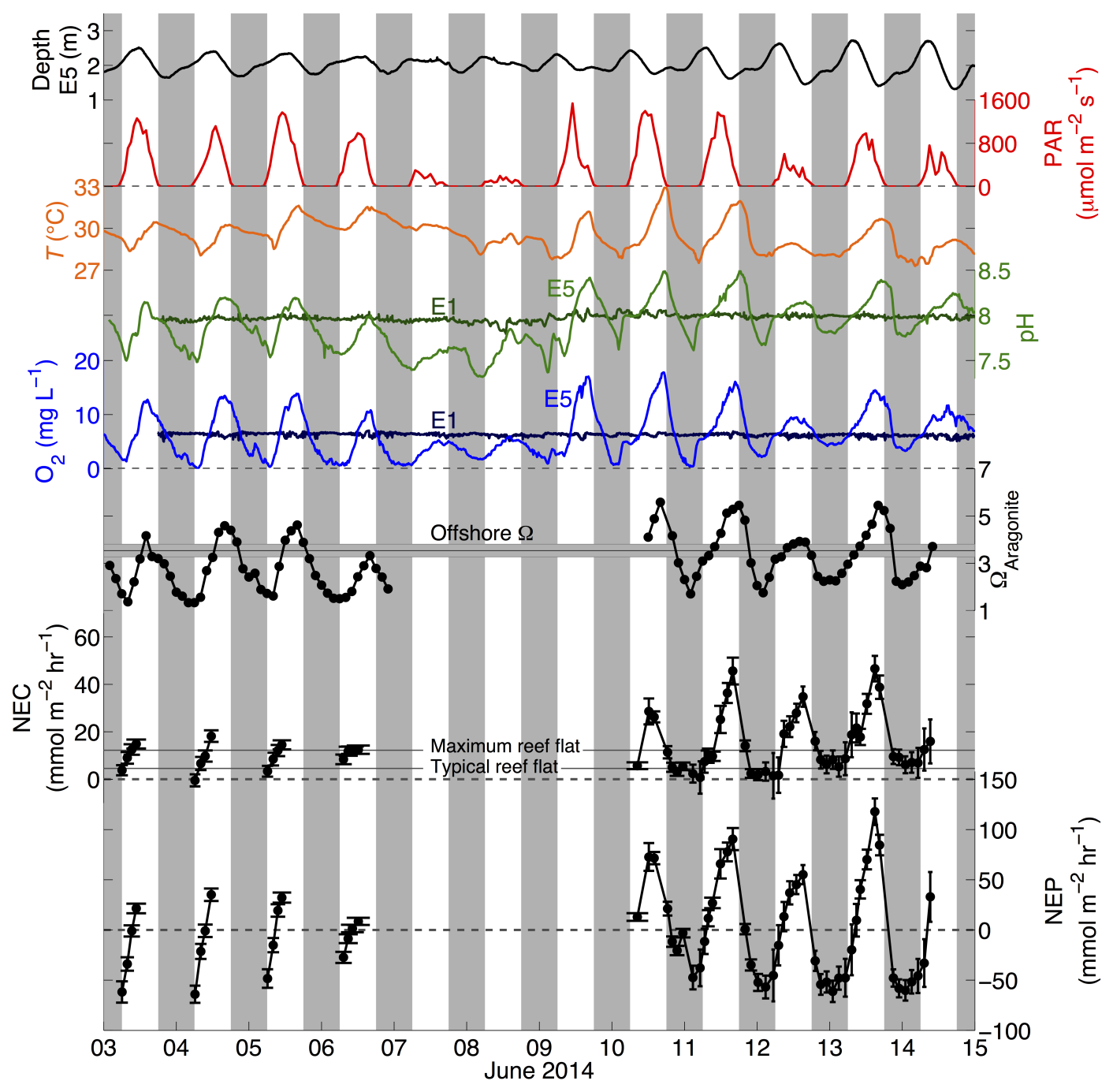

Fig.

S3. Time series of physical and chemical properties, and metabolic rates on the Dongsha Atoll reef flat in June 2014. From top to bottom: sea level, PAR, temperature, $\mathrm{pH}, \mathrm{O}_{2}, \Omega_{\text {Arag }}$, NEC and NEP. For $\mathrm{pH}$ and $\mathrm{O}_{2}$, lighter colors show reef flat measurements at station E5 and darker colors fore reef measurements at station E1. Mean offshore $\Omega_{\text {Arag }}$ and its $1 \sigma$ are plotted as the black horizontal line with gray error bound. NEC and NEP are plotted with vertical error bars representing the uncertainty of the rates and the width of these error bars representing the time over which each measurement represents (i.e. the residence time). Horizontal dashed lines show 0 rates that separate calcification from dissolution and photosynthesis from respiration. 

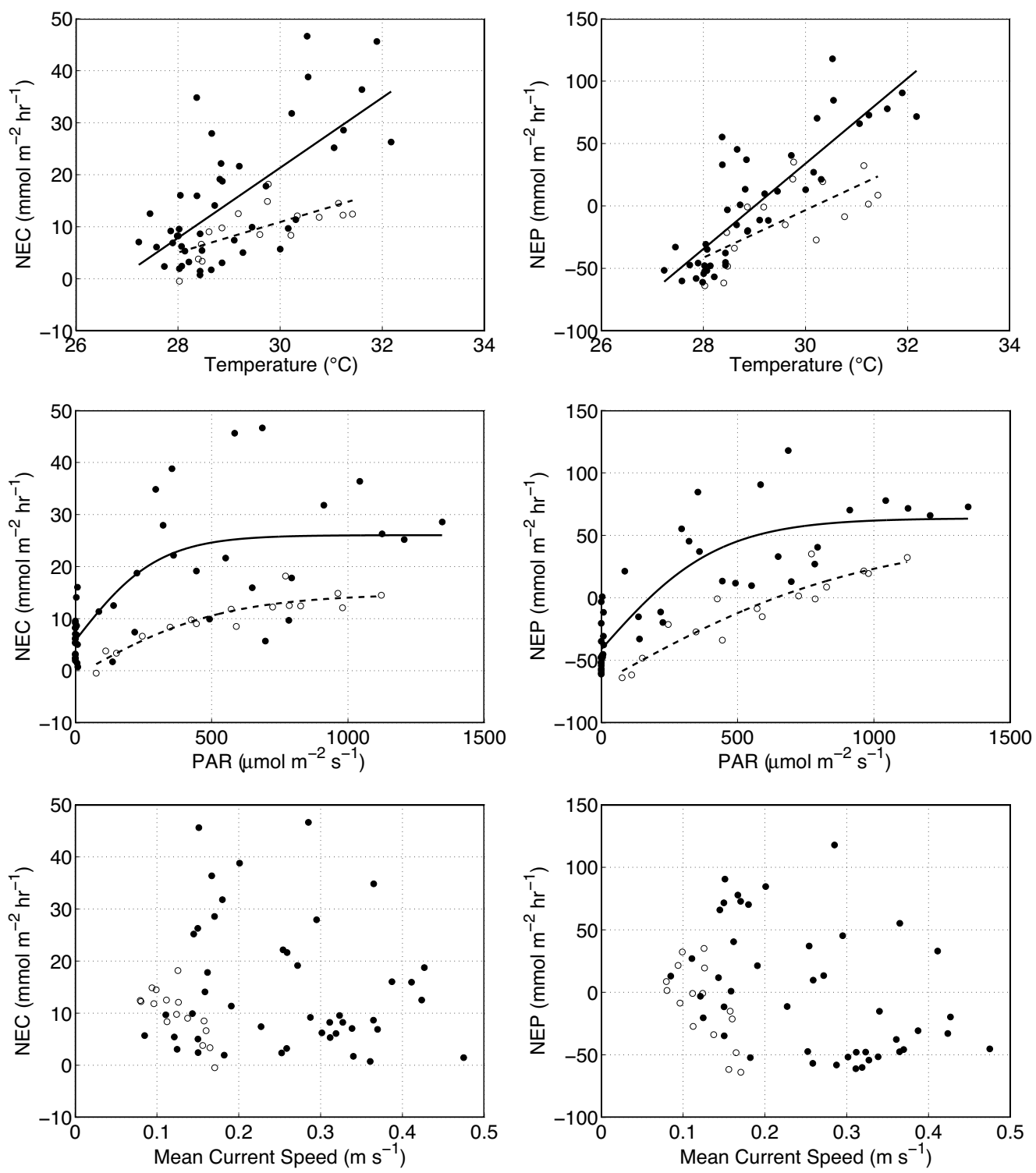

Fig. S4. Correlations between community metabolism and temperature (top), PAR (middle), and current speed (bottom). NEC (left) and NEP (right) measurements are plotted for bleaching (open circles) and post-bleaching (black circles) measurements, and solid (dashed) lines indicate curves fit to the post-bleaching (bleaching) data. At the same temperature and PAR levels, both NEC and NEP were depressed during bleaching relative to post-bleaching. 

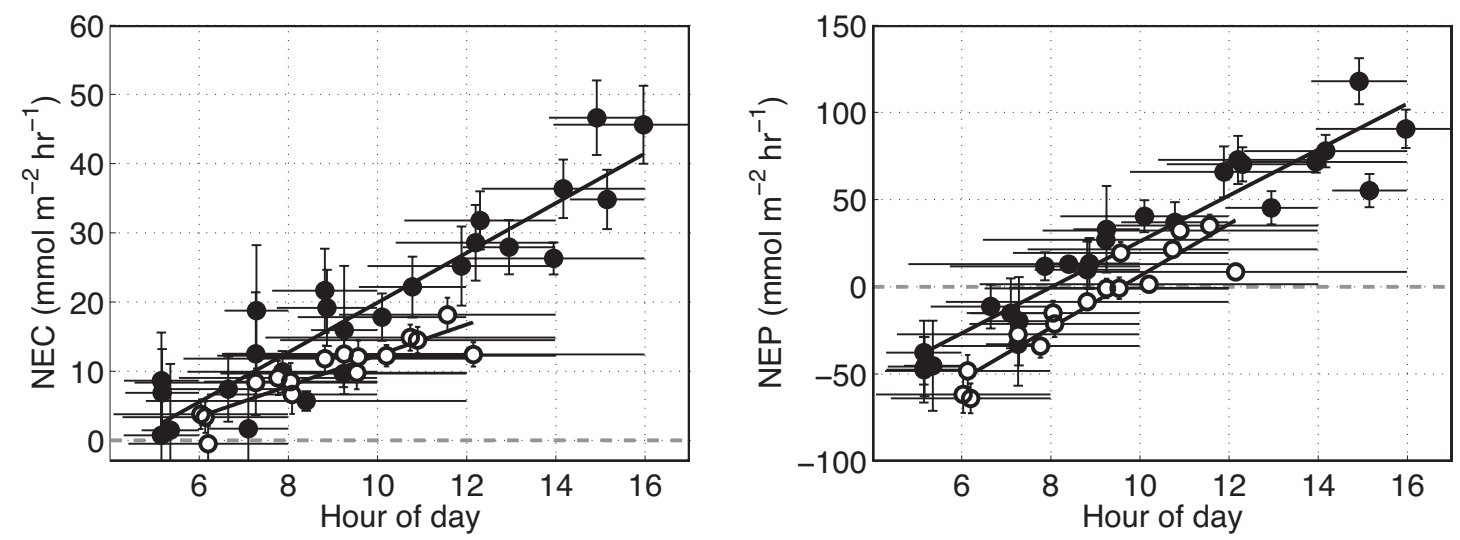

Fig. S5. NEC and NEP measurements during bleaching (white) and post-bleaching (black) for hours of day common to both time periods. All points are plotted on the time axis as the mid-point between the sampling time and the time when the water parcel traversed the reef crest, and the horizontal error bars represent the residence times (i.e. the left end-point is when the water parcel crossed the reef crest and the right end-point is the reef flat sampling time). Based on the residence time mid-points, the two time periods overlap between approximately 06:00 and 12:30, and based on the full residence times, the common times are approximately 05:00 to 16:00. Solid black lines are linear regression fits, which show that NEC and NEP rates were lower during the bleaching event compared to post-bleaching. 


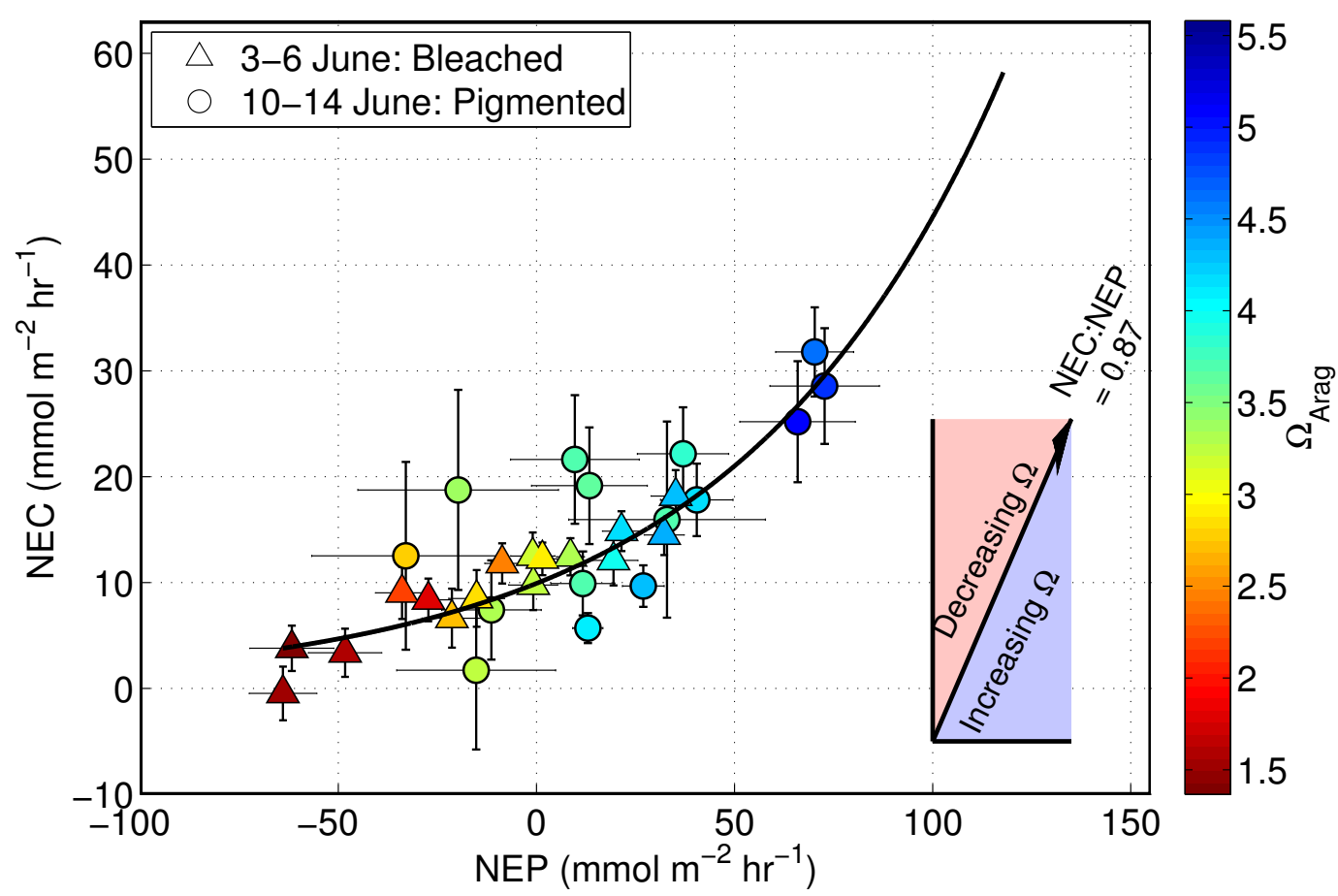

Fig. S6. Correlation between NEC and NEP during bleaching (triangles) and postbleaching (circles) during 06:00 to 12:30. Regression between NEC and NEP using this subset of data shows no significant effect of bleaching. Colors indicate $\Omega_{\text {Arag }}$ at station E5 corresponding to the metabolic rate measurement times. Solid black line is exponential fit between NEC and NEP using all of the data (see Fig. 8 in main text). Theoretical vector in lower right shows the slope between NEC and NEP (0.87) that maintains an approximately constant $\Omega_{\text {Arag }}$. Greater slopes decrease $\Omega_{\text {Arag }}$ and lesser slopes increase $\Omega_{\text {Arag }}$. The exponential curve is increasing in slope at higher NEP, but is always less than the 0.87 critical value, and thus the highest $\Omega_{\text {Arag }}$ values correspond to the highest NEC and NEP rates. 


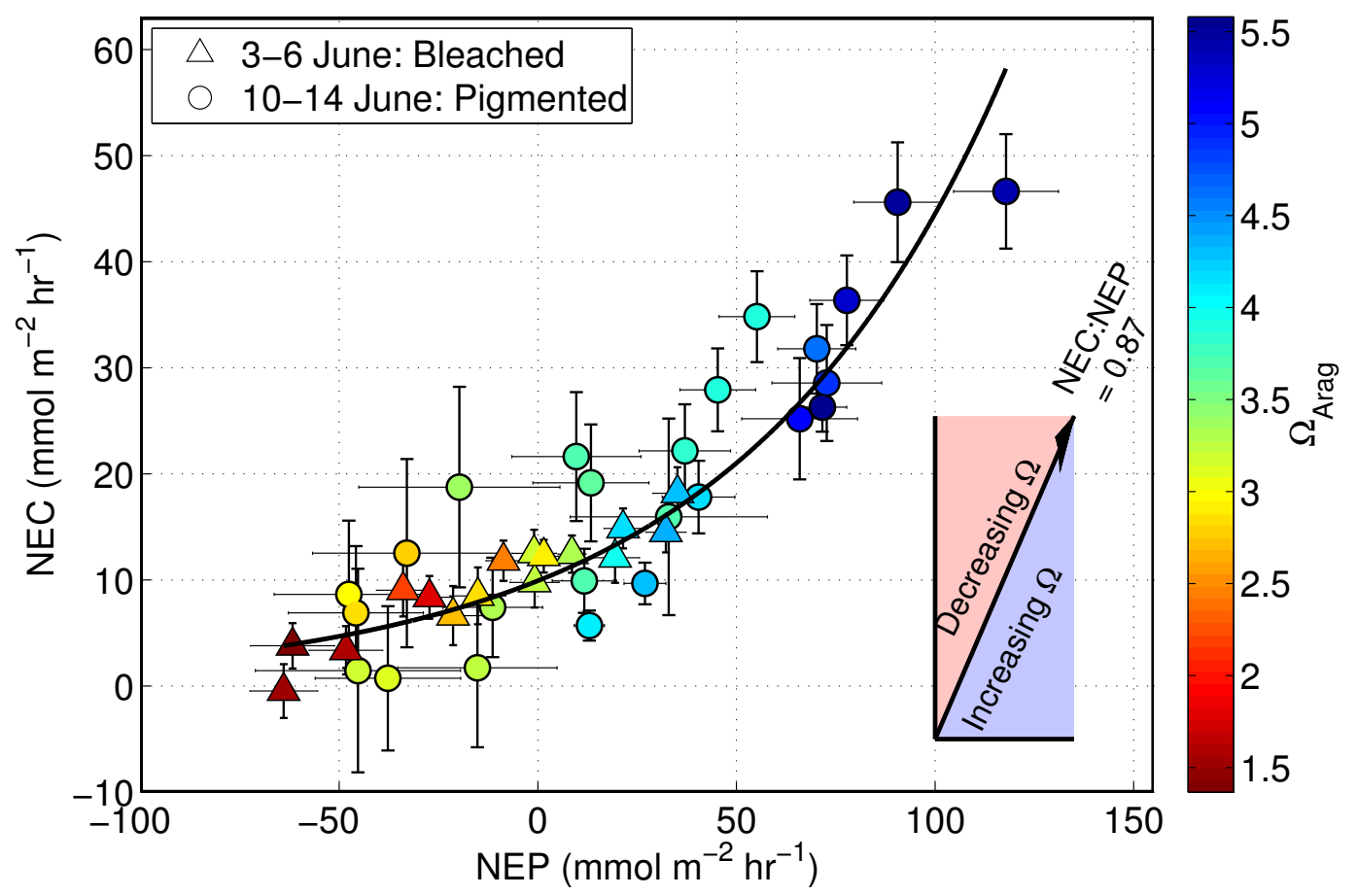

Fig. S7. Same as Fig. S6, but including measurements between 05:00 and 16:00. 


\section{Chapter 6}

\section{Mass coral mortality under local amplification of $2{ }^{\circ} \mathrm{C}$ ocean warming}

\subsection{Abstract}

A $2{ }^{\circ} \mathrm{C}$ increase in global temperature above pre-industrial levels is considered a reasonable target for avoiding the most devastating impacts of anthropogenic climate change. In June 2015, sea surface temperature (SST) of the South China Sea (SCS) increased by $2{ }^{\circ} \mathrm{C}$ in response to the developing Pacific El Niño. On its own, this moderate, short-lived warming was unlikely to cause widespread damage to coral reefs in the region, and the coral reef "Bleaching Alert" alarm was not raised. However, on Dongsha Atoll, in the northern SCS, unusually weak winds created low-flow conditions that amplified the $2{ }^{\circ} \mathrm{C}$ basin-scale anomaly. Water temperatures on the reef flat, normally indistinguishable from open-ocean SST, exceeded $6{ }^{\circ} \mathrm{C}$ above normal summertime levels. Mass coral bleaching quickly ensued, killing $40 \%$ of the resident coral community in an event unprecedented in at least the past 40 years. Our findings highlight the risks of $2{ }^{\circ} \mathrm{C}$ ocean warming to coral reef ecosystems when global and

DeCarlo T.M., Cohen A.L., Wong G.T.F., Davis K.A., Lohmann P., Soong K. (submitted). Mass coral mortality under local amplification of $2{ }^{\circ} \mathrm{C}$ ocean warming. Scientific Reports 
local processes align to drive intense heating, with devastating consequences.

\subsection{Introduction}

An historic international agreement reached at the Conference of Parties 21st session (COP21) aims to limit global warming within $2{ }^{\circ} \mathrm{C}$ above pre-industrial levels by reducing greenhouse gas emissions, an attempt to avert the most devastating impacts of climate change (UNFCCC, 2015). Yet there is growing concern that the $2{ }^{\circ} \mathrm{C}$ limit is wholly insufficient to protect the world's at-risk populations and ecosystems (Victor and Kennel, 2014; Tschakert, 2015). Tropical coral reefs, which provide hundreds of millions of people worldwide with food and income, fall in this category (HoeghGuldberg et al., 2007; Pandolfi et al., 2011; Costanza et al., 2014). Considered the ocean's most productive ecosystems, coral reefs are particularly sensitive to ocean warming, which disrupts the symbiotic relationship between the coral animal and its photosynthetic algae. Bleaching, so-called because the coral turns white as it expels damaged algae, is lethal if prolonged (Baker et al., 2008). In the past 30 years, coral bleaching caused by ocean warming has contributed to the loss of $19 \%$ of the world's coral reef area (Glynn, 1993; Wilkinson, 2008).

Global climate model simulations of open-ocean warming under business-as-usual greenhouse gas emissions scenarios imply that bleaching will occur annually on over $80 \%$ of the world's remaining reefs by the second half of this century (Frieler et al., 2012; van Hooidonk et al., 2013). Strategies designed to cap ocean warming have potential to reduce or at least delay these impacts (Frieler et al., 2012; van Hooidonk et al., 2013), and some corals may be able to adapt to moderate rates of warming (Frieler et al., 2012; Palumbi et al., 2014). Critically however, the thermal environments of most tropical coral reef ecosystems do not resemble those of the open ocean (Davis et al., 2011; DeCarlo et al., 2015b; Wall et al., 2015). Limited by availability of light, tropical reefs flourish in shallow waters, even those perched atop undersea volcanoes whose bases stretch kilometers to the seafloor. In these shallow environments, regional weather conditions and local hydrodynamics exert strong influence and when 
they align, a moderate open-ocean warming can quickly translate to intense heating on the reef, with devastating consequences.

Here we document the physical and ecological consequences of such an alignment on Dongsha Atoll, a coral reef in the northern South China Sea (SCS). We developed a reef-flat heat budget to diagnose the physical drivers of warming in June 2015, linking it to a regional atmospheric anomaly, and we tracked the coral community response to extreme thermal stress. Finally, we evaluate the historical precedence for an event of this magnitude using markers of thermal stress preserved in the skeletons of long-lived corals.

\subsection{Methods}

\subsubsection{Climate data}

Sea surface temperature (SST) data were acquired from the Extended Reconstructed SST (ERSST) product (Smith et al., 2008), NOAA Optimum Interpolation (NOAAOI) (Reynolds et al., 2002), NOAA Coral Reef Watch (Watch, 2013), and Moderate Resolution Imaging Spectroradiometer (MODIS) (NASA Goddard Space Flight Center, Ocean Ecology Lab, 2014). The different SST products possess a range of temporal coverage and spatial resolution. ERSST covers the entire 20th century at relatively course $\left(2^{\circ}\right.$ by $\left.2^{\circ}\right)$ resolution, NOAA-OI begins in 1982 at $1^{\circ}$ resolution (Fig. 6-1), Coral Reef Watch begins only in 2013 at high resolution (5 km), and MODIS covers only 2002-present but at very high spatial resolution $(4 \mathrm{~km})$. ERSST and NOAA-OI anomalies were calculated relative to the 1940-1970 ERSST mean. The NOAA Coral Reef Watch program calculated monthly climatologies for 1985-1993, and we used this as the climatology in our assessment of SST anomalies in the open ocean around Dongsha Atoll during June 2015. ERSST data were used to evaluate the centennial-scale warming trend in the northern South China Sea (Fig. 6-1). MODIS was used to plot the high-resolution distribution of SST in and around Dongsha Atoll at the time of bleaching (Fig. 6-2c). Sea level pressure (SLP) data were 
acquired from the National Centers for Environmental Prediction / National Center for Atmospheric Research (NCEP/NCAR) Reanalysis (Kalnay, 1996). Monthly SLP anomalies were calculated relative to the 1949-2015 monthly climatology.

\subsubsection{Local reef conditions}

The physical conditions leading to the bleaching event were monitored with a series of instruments deployed on Dongsha Island and underwater on the reef flat. Solar radiation, wind speed, air temperature, precipitation, and relative humidity were measured every 6 minutes on Dongsha Island with a meteorological station maintained by the Dongsha Atoll Research Station. Seawater temperature was monitored on the Dongsha Atoll eastern reef flat (station E5) at $2 \mathrm{~m}$ depth, on the eastern fore reef (station E1) at $7 \mathrm{~m}$ depth, and in the channel north of Dongsha Island at $5 \mathrm{~m}$ depth with Onset Hobo U22 temperature loggers deployed on buoys $0.5 \mathrm{~m}$ above the bed (accuracy $\pm 0.1{ }^{\circ} \mathrm{C}$ after calibration in an isothermal bath) and sampling every 15

minutes. Currents at station E5 on the reef flat were measured between June 2014 and June 2015 with a Lowell Instruments Tilt Current Meter (TCM; sampling every 5 minutes in 1-minute bursts at $8 \mathrm{~Hz}$ ) and in June 2013 and June 2014 with Nortek Aquadopp acoustic Doppler current profilers (ADP; sampling every 4 minutes). The TCM was calibrated to the depth-mean current velocity measured by an ADP during a 1-week co-deployment at station E5 $(\mathrm{r}=0.86)$.

\subsubsection{Heat budget calculations}

We used the meteorological data to estimate the air-sea heat flux in June 2015 as the sum of latent, sensible, longwave radiation, and shortwave radiation fluxes. Longwave radiation was estimated following Reed (1976), and latent and sensible fluxes were estimated using bulk-formula calculations with COARE 2.6 (Fairall et al., 2003) following the approach previously developed and validated on Red Sea reefs with similar bathymetry to the Dongsha reef flat (Davis et al., 2011). Heat fluxes were converted 
to temperature $(T)$ change by:

$$
\frac{d T}{d t}=\frac{Q}{\rho c_{p} h}
$$

where $t$ is time, $Q$ is heat flux in $\mathrm{W} \mathrm{m}^{-2}, \rho$ is seawater density $\left(\mathrm{kg} \mathrm{m}^{-3}\right), c_{p}$ is the heat capacity of seawater ( $\left.\mathrm{W} \mathrm{s} \mathrm{kg}-1{ }^{\circ} \mathrm{C}^{-1}\right)$, and $h$ is water depth $(\mathrm{m})$. The total heat budget (in ${ }^{\circ} \mathrm{C} \mathrm{hr}-1$ ) on the reef flat was calculated by taking the time-derivative of measured water temperature, and the advective component was estimated as the difference between total (observed) and air-sea (calculated) components (benthic and diffusive heat fluxes assumed negligible).

\subsubsection{Ecological surveys}

Ecological surveys were conducted at 8 stations across the reef flat and 2 stations on the fore reef following a protocol similar to previously established methods for characterizing benthic cover on coral reefs (Golbuu et al., 2007). Pre-bleaching surveys were conducted between 29 May and 7 June (reported in Chapter 5), and post-bleaching surveys were conducted between 27 July and 2 August. At each station, 5x 50 m transects were laid out and photographed every meter ( $0.5 \mathrm{~m}$ by $0.5 \mathrm{~m}$ image area), giving a total of 250 photos per station. Transects were oriented N-S (along-shore) and spaced $5 \mathrm{~m}$ apart (cross-shore). Images were analyzed using the program Coral Point Count (Kohler and Gill, 2006) with 5 randomly placed points per image identified to coral genera or benthic substrate type (Appendix F). The same survey methodology was repeated at the same locations pre- and post-bleaching for reef flat stations (E2E6), while fore reef station E1 was surveyed only post-bleaching. The channel north of Dongsha Island was inspected visually for bleaching on 24 June and 29 July, but no photo surveys were conducted. In total, we made 22,500 point identifications in our study. All corals, whether alive and pigmented, bleached, or recently dead were identified to genera level. Bleached corals were identified based on lack of pigment and the presence of live polyps, whereas recently dead corals were distinguished based on structurally intact corallites without any live polyps present. 


\subsubsection{Bleaching histories}

Coral skeletal cores were collected from massive Porites colonies using underwater pneumatic drills with $3 \mathrm{~cm}$ diameter drill bits. The cores were scanned at Woods Hole Oceanographic Institution Computerized Scanning and Imaging Facility and skeletal density was calculated by comparison to previously calibrated coral skeletal density standards (DeCarlo et al., 2015a). Annual calcification rates were calculated using the software program coralCT (DeCarlo and Cohen, 2016) and the mean calcification rate was calculated for 2007-2012, the years that are overlapping among all colonies. Stress bands were identified visually in 1983 (1/3 cores), 1998 (5/13 cores) and 2007 (6/22 cores) from coral CT scans following previous studies that linked observed bleaching with anomalous high-density band formation (Mendes and Woodley, 2002; Carilli et al., 2009; Cantin and Lough, 2014; Barkley and Cohen, 2016). We determined the linear trend of annual calcification rates from 1990-2013 [(1.310 $\left.\pm 0.031 \mathrm{~g} \mathrm{~cm}^{-2} \mathrm{yr}^{-1}\right)$ $\left.+\left(0.0061 \pm 0.0024 \mathrm{~g} \mathrm{~cm}^{-2} \mathrm{yr}^{-2}\right)\right]$ (standard error), following the statistical approach of Castillo et al. (2012) that accounts for fixed effects among cores and autocorrelation within the time series. Estimated mean calcification rates for $1998(1.36 \pm 0.04 \mathrm{~g}$ $\left.\mathrm{cm}^{-2} \mathrm{yr}^{-1}\right)$ and $2007\left(1.47 \pm 0.07 \mathrm{~g} \mathrm{~cm}^{-2} \mathrm{yr}^{-1}\right)$ were within uncertainty of measured calcification rates measured for those years $\left(1.38 \pm 0.03 \mathrm{~g} \mathrm{~cm}^{-2} \mathrm{yr}^{-1}\right.$ and $1.43 \pm$

$0.03 \mathrm{~g} \mathrm{~cm}^{-2} \mathrm{yr}^{-1}$, respectively), indicating that there were no significant declines in calcification during these past bleaching events.

\subsection{Results and Discussion}

The ocean surface surrounding coral reefs in the northern SCS has warmed at a rate of $0.09 \pm 0.015{ }^{\circ} \mathrm{C}(95 \%$ confidence) per decade since 1900 (Fig. 6-1), closely tracking the warming trend globally $\left(0.071 \pm 0.013{ }^{\circ} \mathrm{C}\right.$ per decade) (Hartmann et al., 2013; Rhein et al., 2013), and in most coral reef regions (Fitt et al., 2001; Jokiel and Brown, 2004; Hoegh-Guldberg et al., 2014) (Fig. 6-1a). In spring and summer 2015, weakened surface winds in the northern SCS associated with a developing Pacific El Niño and diminished sea to air latent heat flux (Kleypas et al., 2015; Rong et al., 2007; 
Liu et al., 2013), were superimposed on this secular trend (Fig. 6-1d-e). Anomalous warming of the sea surface culminated in a June SST anomaly $2{ }^{\circ} \mathrm{C}$ above the 1985 1993 climatological mean for that time of year (Fig. 6-2e). The open-ocean SST anomaly was not high enough for long enough to raise NOAA's Coral Reef Watch "Bleaching Alert" (Fig. 6-2b), and coral bleaching was not anticipated in the northern SCS in June 2015 (Watch, 2013; Liu et al., 2014).
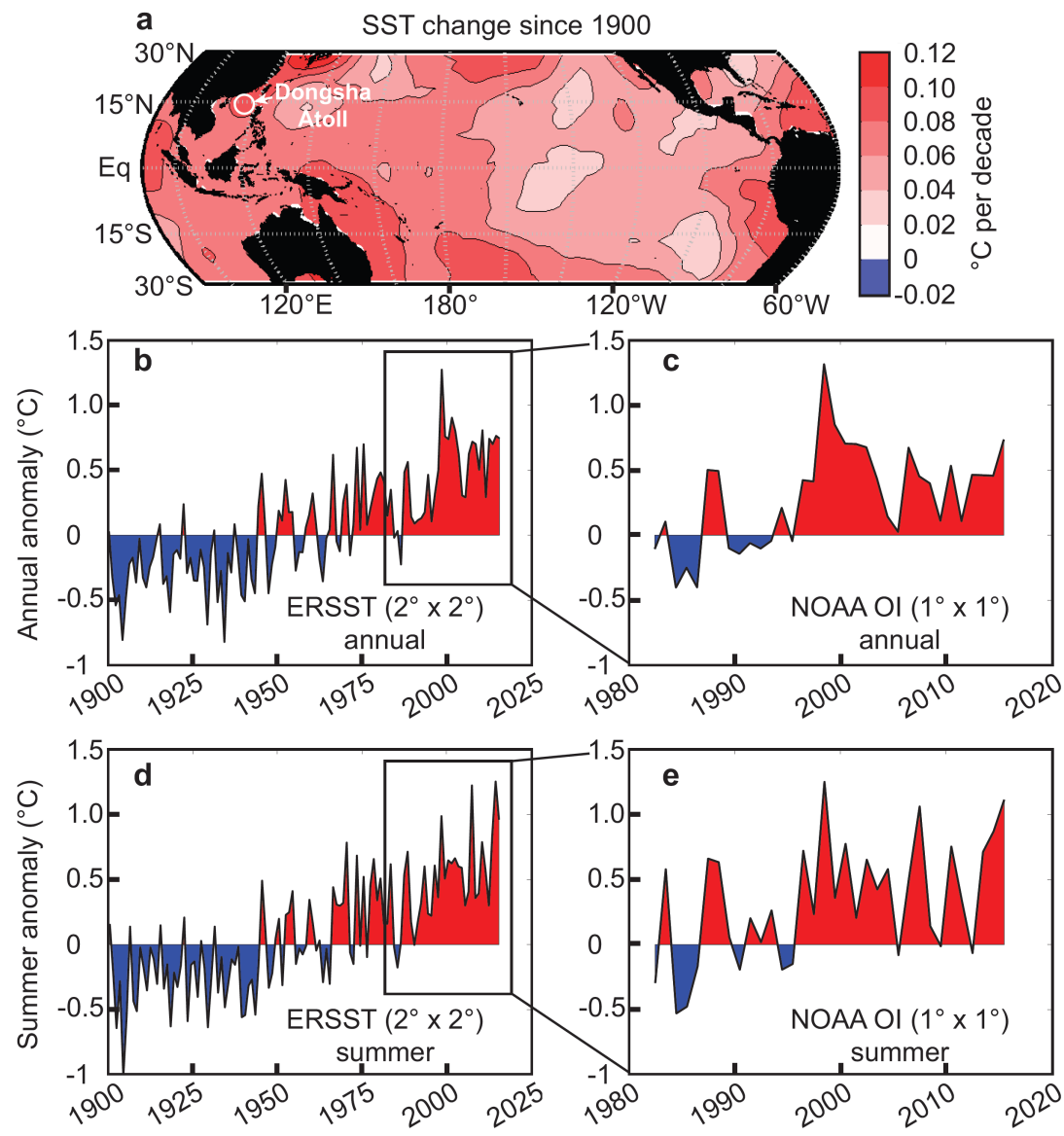

Figure 6-1: Historical sea surface temperature (SST) changes. a, Map of the rate of SST increase since 1900 (data from Extended Reconstructed Sea Surface Temperature, ERSST). The northern SCS has warmed at a rate similar to other coral reef regions such at the Great Barrier Reef, Melanesia, and the eastern Caribbean. b-c, annual mean and d-e, summer (June-July-August, or JJA) SST anomalies for the open-ocean surrounding Dongsha Atoll. The data are plotted in $b$ and $d$ for 1900-2015 from ERSST and in $\mathrm{c}$ and e for 1982-2015 from NOAA Optimal Interpolation (OI). In all panels, the data are derived from the single gridbox $\left(2^{\circ}\right.$ resolution for ERRST and $1^{\circ} \mathrm{C}$ resolution for OI) covering Dongsha Atoll. Red and blue shading corresponds to years that were warmer or cooler, respectively, than the 1940-1970 climatology calculated from ERSST. Anomalously warm SST often occurred in the South China Sea during strong El Niño events, especially pronounced in summertime during 1998, 2007, and 2015. 
Dongsha Atoll is a massive (25 km diameter), circular coral reef emerging from $500 \mathrm{~m}$ water depth on the continental shelf slope in the northern SCS. The living reef flat encircling the lagoon is just 1-3 m deep (Fig. 6-2d), as is characteristic of many coral atolls, and barrier and fringing reefs worldwide. In summer, water on the shallow reef is heated during the day by solar insolation, and cooled via advection of relatively cooler offshore water across the reef flat by tidal and wave-driven currents. Consequently, daily average temperatures on the reef flat resemble those of the surrounding open ocean. Indeed, mean temperature recorded by our in situ logger on the reef flat during June-July-August (JJA) of 2013-2015 was $29.7^{\circ} \mathrm{C}$, nearly identical to that of the surrounding open ocean $\left(29.6{ }^{\circ} \mathrm{C}\right.$ in both NOAA-OI and NOAA Coral Reef Watch) (Supplementary Fig. S1). However, in June 2015 however, an anomalous high-pressure system (Fig. 6-2b) resulted in reduced wind speeds and surface waves across the northern SCS. As a result, current speeds on the reef flat decreased by $40-60 \%$ compared to the previous two years (Supplementary Fig. S2), disrupting the local heat budget. For several days, heating from solar insolation exceeded the advective cooling that normally keeps the reef flat at open-ocean temperatures, adding $4{ }^{\circ} \mathrm{C}$ to the relatively modest $2{ }^{\circ} \mathrm{C}$ open-ocean anomaly. Reef-flat temperatures peaked in excess of $6{ }^{\circ} \mathrm{C}$ above the climatological mean June SST (Fig. 6-2 and Supplementary Figs. S1-3). We diagnosed the causes of this transient heating event using high-resolution physical measurements and a heat-budget analysis. The extreme temperature $\left(36{ }^{\circ} \mathrm{C}\right)$ reached in June 2015 was anomalous, a result of global (El Niño warming superimposed upon a global warming trend), regional (high pressure system and reduced winds), and local hydrodynamic (shallow reef, neap tide and unusually slow currents) factors aligning - at the right time - to drive intense heating (see Supplementary Information for additional details).

Ecological surveys conducted across the reef flat in early June prior to the bleaching event, and again in late July after the bleaching provide a rare quantitative characterization of the response of the benthic community to extreme thermal stress (Baker et al., 2008). In early June, live, healthy coral on the reef flat covered $22 \%$ of the benthic area. By late July, bleaching gave way to mass mortality and the cover of 


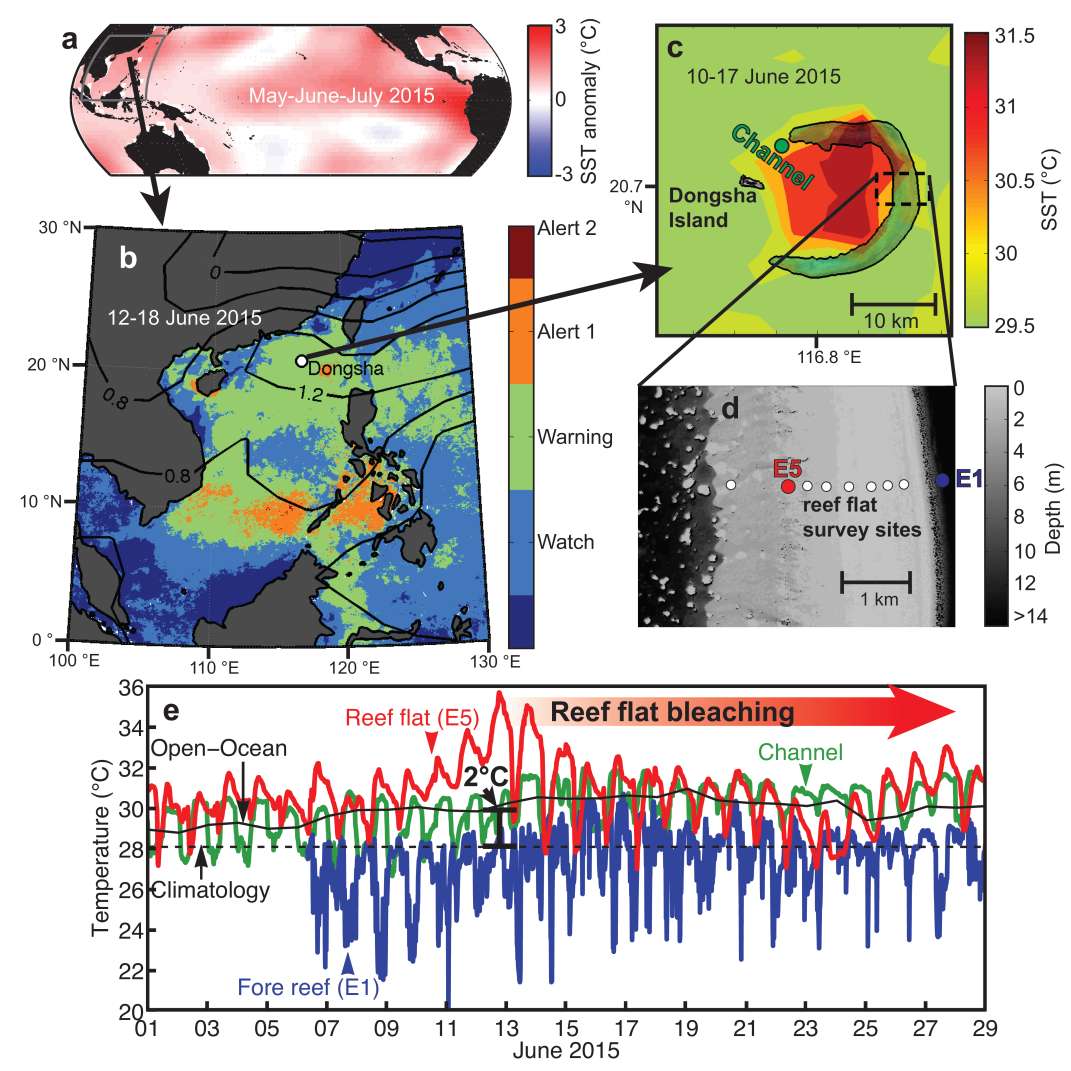

Figure 6-2: Local amplification of regional warming. a, May-June-July (MJJ) 2015 SST anomalies relative to the 1940-1970 (May-June-July, or MJJ ) ERSST climatology shows Pacific basin-wide warming in response to developing El Niño conditions. b, NOAA Coral Reef Watch 7-day maximum alert level (colours) for the South China Sea region 12-18 June 2015. Black contours are June 2015 monthly sea level pressure anomaly $(\mathrm{hPa})$ from NCEP/NCAR reanalysis, showing a high-pressure system centered over Dongsha Atoll (white circle). c, SST in and around Dongsha Atoll 10-17 June 2015 derived from 4-km MODIS data. SST is higher within the lagoon and on the submerged reef flat compared to the adjacent open-ocean. Dashed black box is where ecological surveys were conducted. d, Bathymetry map of the eastern reef flat highlights the shallow habitat created by the atoll. e, Temperatures captured by in situ loggers on the reef flat (red), in the channel (green), and on the fore reef (blue); and open-ocean (solid black) and the open-ocean climatological mean for June (dashed grey; NOAA Coral Reef Watch 5-km product). Open-ocean temperatures were $2{ }^{\circ} \mathrm{C}$ above normal (black bar) in mid-June but were amplified to $6{ }^{\circ} \mathrm{C}$ on the shallow reef flat, triggering mass bleaching and mortality.

live, un-bleached coral was halved to $11 \%$ of the benthic area. Our ecological survey point-counts showed 33-40\% of coral points recently dead and 10\% still bleached (Fig. 6-3). The response of the benthic community was exceptionally fast. Whereas corals typically bleach - and recover - in response to several months of accumulated heating or cooling (Liu et al., 2014; Schmidt et al., 2016), corals on the Dongsha reef flat 
bleached within 1 week of peak temperatures and $90 \%$ of them were either recovered or dead less than 6 weeks later.

In contrast to the reef flat, coral communities in the channel north of Dongsha Island were not exposed to local amplification, and those on the upper fore reef slope were cooled by internal waves. Large-amplitude internal waves are generated on tidal frequencies in the Luzon Strait to the east of Dongsha Atoll and propagate along the thermocline (70-100 m depth) into the northern SCS (Wang et al., 2007; DeCarlo et al., 2015b). When these internal waves collide with Dongsha Atoll, they deliver deep, cool water up the fore reef slope (Wang et al., 2007; DeCarlo et al., 2015b). As a consequence, temperatures at $7 \mathrm{~m}$ depth on the fore reef decrease as much as 8 r̆C for several hours each day (DeCarlo et al., 2015b), and during 6-15 June 2015, eastern fore reef temperatures were on average $2.8{ }^{\circ} \mathrm{C}$ cooler than the surrounding open-ocean SST (Fig. 6-2e). Yet over the same time in the channel north of Dongsha Island, where the internal waves are absent, mean temperature was within $0.1^{\circ} \mathrm{C}$ of the open-ocean SST (Figs. 6-2e). Bleaching did not occur on the fore reef or in the channel (Fig. 6-3), implying that the internal waves were sufficient, but not necessary at this time, to relieve thermal stress and prevent bleaching. Critically, the lack of bleaching in the channel indicates that the $2{ }^{\circ} \mathrm{C}$ open-ocean warming was insufficient to drive bleaching on its own, and that the synergy of global, regional, and local drivers of warming was responsible for the mass coral morality event on the reef flat.

We observed strong species-specific patterns in mortality as a result of bleaching (Fig. 6-3). Based on visual surveys conducted on 20 June, all colonies of Porites, Acropora, Pavona, and Stylophora, the four most common coral genera on the reef flat, appeared bleached. However, 6 weeks later, we found only $17 \%$ mortality of Porites in our ecological point count data, compared with $56 \%$ for Acropora (Fig. 63). Contrasting bleaching responses have the potential to shift coral reef community composition in favor of the most resistant species (Grottoli et al., 2014). Branching corals that are most vulnerable to bleaching, such as Acropora, are among the fastest growing coral genera (Dullo, 2005), creating habitat for many other reef taxa (Jones et al., 2004; Bonin, 2012; Pandolfi et al., 2011). Their selective demise, therefore, 


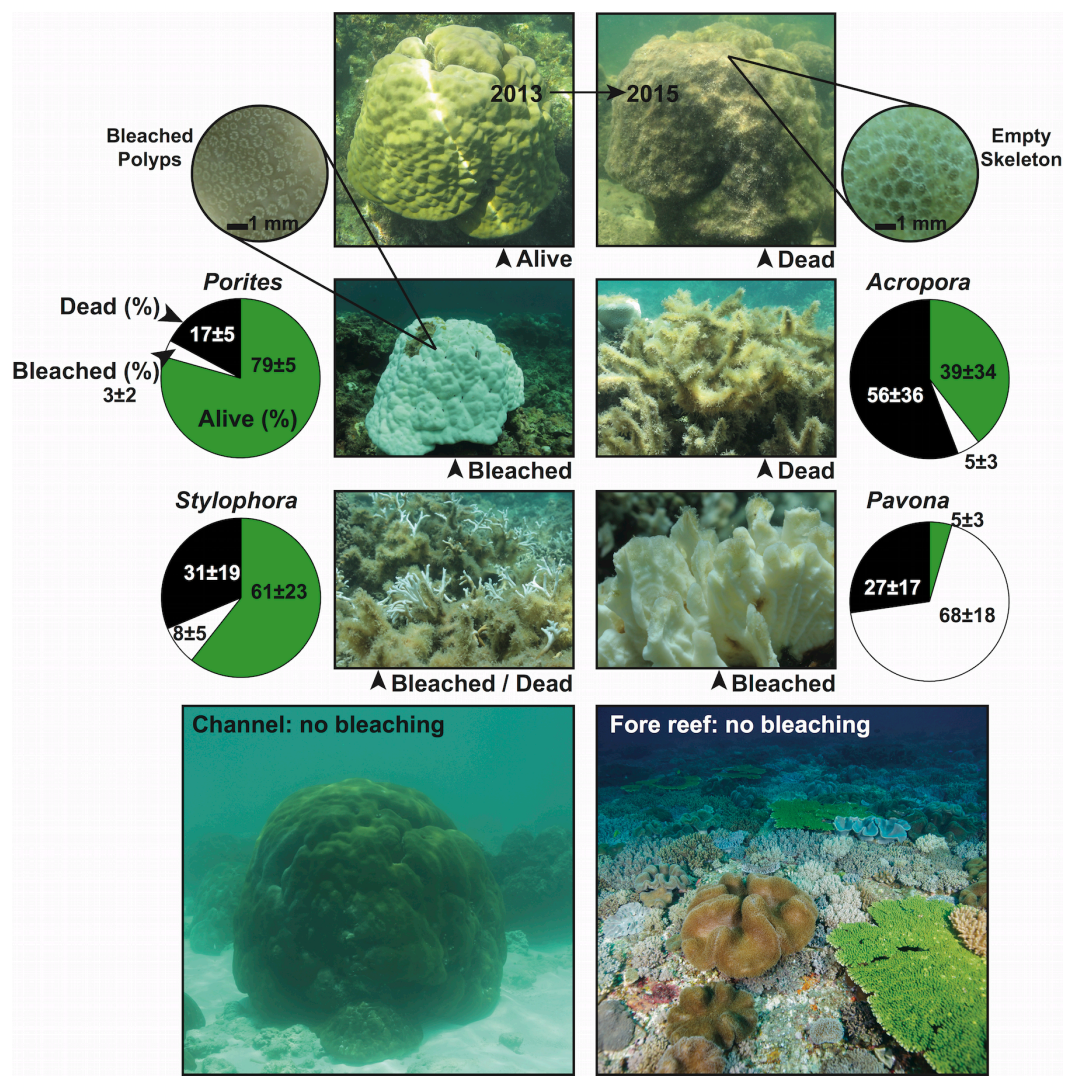

Figure 6-3: Response of the Dongsha Atoll reef flat coral community to thermal stress. At the top, a 100-year old coral colony photographed alive in June 2013 (left) and after its death in July 2015, confirmed by absence of living polyps (inset). Bleaching-induced mortality varied by genus. Green, white, and black areas represent percent of live and healthy/pigmented, bleached, and recently dead corals, respectively, by genus in late July surveys. Bleached Porites colonies continued to host live polyps (inset), whereas most Acropora succumbed quickly and were covered in algae after death. Photos at the bottom show healthy and pigmented corals in the channel and on the upper fore reef slope in late July. The absence of bleaching in the channel was based on visual observations, while no bleached corals were found in ecological surveys conducted on the fore reef.

creates additional problems for the biodiversity of coral reef ecosystems, which harbor an estimated one quarter of all marine species (Knowlton et al., 2010).

Mass bleaching-induced mortality of long-lived corals across the Dongsha reef flat suggests that an event of this magnitude is unusual, and perhaps unprecedented over the past several decades. Bleaching was reported in the waters immediately surrounding Dongsha Island in 1998 (Dai, 2004), but the larger lagoon and reef flat were not monitored at the time. To assess whether past high temperature events in the open ocean drove similar levels of ecological response, we examined skeletal 
cores from massive Porites corals for evidence of stress banding, discrete anomalously high-density bands of skeleton accreted during bleaching (Hudson et al., 1976; Mendes and Woodley, 2002; Carilli et al., 2009; Cantin and Lough, 2014; Barkley and Cohen, 2016). Colonies that bleach but survive and continue to grow, preserve within their skeleton a high-density stress band visible in computerized tomography (CT) scans (Hudson et al., 1976; Mendes and Woodley, 2002; Carilli et al., 2009; Cantin and Lough, 2014). The prevalence of Porites stress bands scales proportionally to community-level bleaching in Palau (Barkley and Cohen, 2016), suggesting that stress bands reliably archive the magnitude of past bleaching events. Partial colony mortality, indicative of severe bleaching, is also visible in CT scans, and reductions in growth due to slow recovery can be quantified from CT images (Mendes and Woodley, 2002; Carilli et al., 2009; Cantin and Lough, 2014).

We analyzed CT scans of 22 Porites colonies on the reef flat ranging in height from 1 to $1.5 \mathrm{~m}$. Each colony was alive and pigmented in early June, prior to the peak temperature anomaly, all appeared bleached by mid-June, and 11 (i.e. 50\%) of these colonies had died by late July. Average growth rate was $1.5 \mathrm{~cm} \mathrm{yr}^{-1}$ (Fig. 6-4), indicating that these colonies were 70-100 years old. This means that each colony had survived prior high temperatures associated with strong El Niño events in 1983, 1998, and 2007 (Fig. 6-1 and Fig. 6-4). However, our analysis of the skeletal records shows that less than $50 \%$ of the colonies had bleached during these events, compared with $100 \%$ in 2015 (Fig. 6-4), and there were no signs of partial mortality and no significant declines in annual calcification rate. This implies that the 2015 bleaching event was the most severe to hit Dongsha Atoll in at least the past 40 years, and possibly much longer.

Reef-building corals typically live near the upper limits of their thermal tolerance (Glynn, 1993; Baker et al., 2008). Global climate models project that conditions on the majority of coral reefs will exceed these limits by the second half of this century (Frieler et al., 2012; van Hooidonk et al., 2013). Reducing greenhouse gas emissions in an effort to cap open-ocean warming to $2{ }^{\circ} \mathrm{C}$ could delay these impacts and may allow some corals time to acclimate and adapt (Frieler et al., 2012; van Hooidonk 

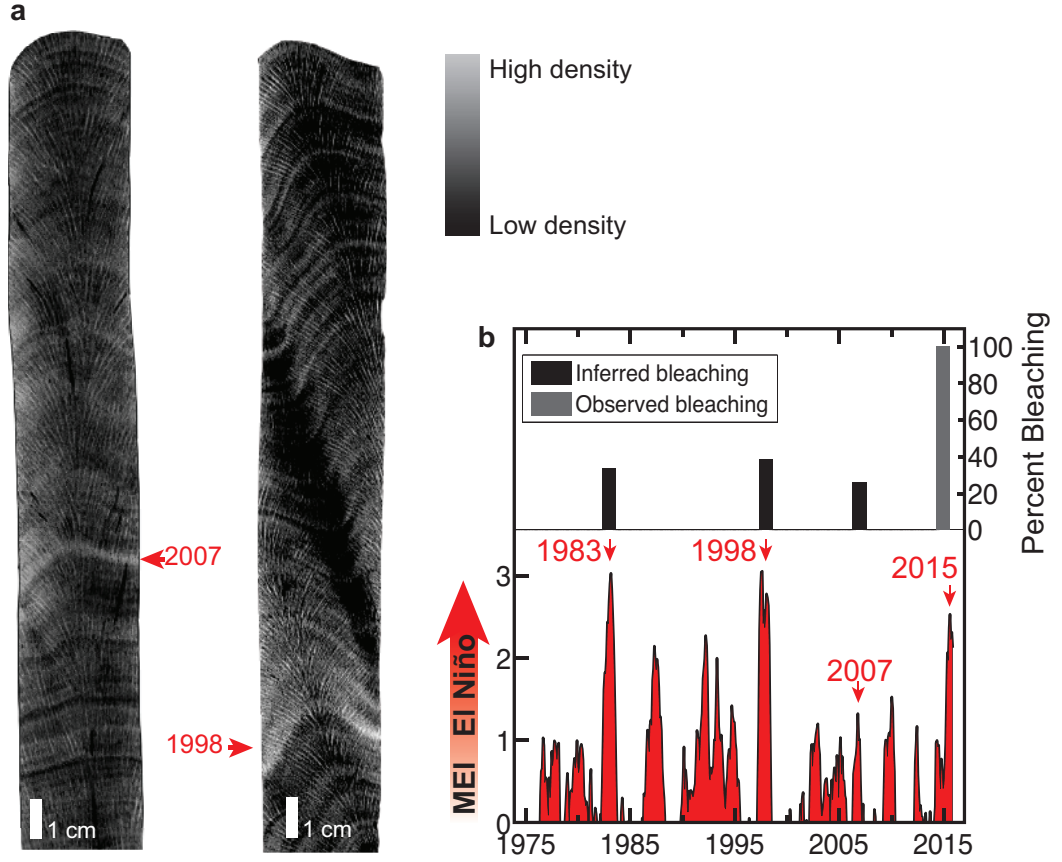

Figure 6-4: Reconstruction of past bleaching on Dongsha Atoll reveals the 2015 event to be unprecedented in 40 years. a, Computerized tomography (CT) scans of skeletal cores extracted from living colonies show annual growth bands and thin, discrete, anomalously high density bands indicative of bleaching in 1998 and 2007. b, High temperature events associated with El Niño (bottom) caused corals to bleach on Dongsha Atoll, as evidenced by the occurrence of stress bands in $30-40 \%$ of Porites in 1983, 1998, and 2007 (top). By comparison, $100 \%$ of Porites colonies bleached in 2015, making this event unprecedented in at least the past 40 years. El Niño events are identified based on the Multivariate ENSO Index (MEI), which quantifies El Niño variability based on a blend of Pacific-wide air pressure, winds, temperatures, and clouds(Wolter and Timlin, 2011).

et al., 2013; Palumbi et al., 2014). However, most projections of coral reef futures under a $2{ }^{\circ} \mathrm{C}$ global warming rely solely on estimates of open-ocean warming without considering the compounding effects of regional climate and local hydrodynamics. Our results indicate that these projections may be overly optimistic for shallow coral reef ecosystems.

\subsection{Supplementary Information}

We used temperature and weather data collected on Dongsha Atoll to investigate the driving factors of the 2015 thermal stress event. Our underwater temperature loggers show that reef flat temperatures generally track offshore SST but with strong diurnal 
and fortnightly variability (Fig. S1). Typically, water temperature on the reef flat is warmer than offshore during the day, and cooler than offshore at night. Fortnightly variability also modulates the daily mean reef flat temperature, occasionally causing multi-day periods when reef flat temperatures are persistently cooler or warmer than offshore (Fig. S1). Much of this fortnightly variability is driven by spring/neap tidal changes in currents, which cool the reef by exchanging reef flat and offshore waters. Associated with most summertime neap tides, when tidal-driven currents are reduced, reef flat temperatures are elevated above the offshore SST for several days. Yet, exceptions to these patterns exist. During June 2015, weak winds associated with an unusual atmospheric high-pressure system in the northern SCS reduced currents speeds by 40-60\% compared to June 2013 and June 2014 (Fig. S2). As a consequence, daily mean reef flat temperatures were consistently warmer than offshore SST during the entire first half of June 2015, throughout both spring and neap tides (Fig. S1).

Using our suite of physical measurements, we calculated a June 2015 heat budget for the reef flat (Materials and Methods section). From the beginning of June 2015 to the onset of bleaching in mid-June, relatively high air temperatures, insolation, and humidity; and low wind speeds created favorable conditions for high air-to-sea heat flux (Fig. S3). However, while water temperatures increased $>4{ }^{\circ} \mathrm{C}$ between early and mid-June, the calculated air-sea heat flux maintained a consistent diurnal cycle of nearly constant amplitude (Fig. S3). This suggests that the advective component of the heat budget was responsible for the warming between early and mid-June. Indeed, the calculated advective heat flux shows large cooling events that occur daily, but begin to diminish in strength and nearly disappear during neap tide on 11 June (Fig. S3). Intense heating on the reef flat during neap tide is common, however, and certainly not unique to June 2015. For example, neap tide heating events of similar magnitude are evident in June-July 2014 and in May 2015 (Fig. S1). The mid-June 2015 heating is set apart from the previous two years of temperature variability because the neap tide warming was superimposed on to already anomalously warm offshore SST, and on to reef temperatures that were already elevated above the offshore SST under anomalously slow currents that persisted for 2 weeks (Fig. S2). 
In our ecological surveys, total coral cover (including live, bleached, and dead) was in excellent agreement pre- and post-bleaching for stations E2, E3, E4.5, E5, and E6, but total pre-bleaching coral cover was greater than that observed in postbleaching surveys for stations E2.5, E3.5, and E4 (Appendix F). Thick algal turfs, which quickly overgrow and obscure recently dead corals, make our recently dead coverage a lower-bound estimate (Fig. S4).

\section{Bibliography}

Baker, A. C., Glynn, P. W., Riegl, B., 2008. Climate change and coral reef bleaching: An ecological assessment of long-term impacts, recovery trends and future outlook. Estuarine, Coastal and Shelf Science 80 (4), 435-471.

Barkley, H. C., Cohen, A. L., 2016. Skeletal records of community-level bleaching in Porites corals from Palau. Coral Reefs, 1-11.

Bonin, M. C., 2012. Specializing on vulnerable habitat: Acropora selectivity among damselfish recruits and the risk of bleaching-induced habitat loss. Coral Reefs 31 (1), 287-297.

Cantin, N. E., Lough, J. M., 2014. Surviving Coral Bleaching Events: Porites Growth Anomalies on the Great Barrier Reef. PLoS One 9 (2), e88720.

Carilli, J. E., Norris, R. D., Black, B., Walsh, S. M., McField, M., 2009. Centuryscale records of coral growth rates indicate that local stressors reduce coral thermal tolerance threshold. Glob. Change Biol. 16 (4), 1247-1257.

Castillo, K. D., Ries, J. B., Weiss, J. M., Lima, F. P., 2012. Decline of forereef corals in response to recent warming linked to history of thermal exposure. Nature Climate Change 2, 756-760.

Costanza, R., de Groot, R., Sutton, P., van der Ploeg, S., Anderson, S. J., Kubiszewski, I., Farber, S., Turner, R. K., 2014. Changes in the global value of ecosystem services. Global Environmental Change 26, 152-158.

Dai, C. F., 2004. Dong-sha Atoll in the South China Sea: Past, Present and Future. In: Islands of the World VIII International Conference, Kinmen Island, Taiwan.

Davis, K. A., Lentz, S. J., Pineda, J., Farrar, J. T., Starczak, V. R., Churchill, J. H., 2011. Observations of the thermal environment on Red Sea platform reefs: a heat budget analysis. Coral Reefs 30, 25-36. 
DeCarlo, T. M., Cohen, A. L., 2016. coralCT: software tool to analyze computerized tomography $(\mathrm{CT})$ scans of coral skeletal cores for calcification and bioerosion rates. URL http://zenodo.org/record/57855

DeCarlo, T. M., Cohen, A. L., Barkley, H. C., Cobban, Q., Young, C., Shamberger, K. E., Brainard, R. E., Golbuu, Y., 2015a. Coral macrobioerosion is accelerated by ocean acidification and nutrients. Geology 43 (1), 7-10.

DeCarlo, T. M., Karnauskas, K. B., Davis, K. A., Wong, G. T., 2015b. Climate modulates internal wave activity in the Northern South China Sea. Geophysical Research Letters 42 (3), 831-838.

Dullo, W.-C., 2005. Coral growth and reef growth: a brief review. Facies 51 (1-4), $33-48$.

Fairall, C. W., Bradley, E. F., Hare, J. E., Grachev, A. A., Edson, J. B., 2003. Bulk Parameterization of AirâĂŞSea Fluxes: Updates and Verification for the COARE Algorithm. Journal of Climate 16 (4), 571-591.

Fitt, W. K., Brown, B. E., Warner, M. E., Dunne, R. P., 2001. Coral bleaching: interpretation of thermal tolerance limits and thermal thresholds in tropical corals. Coral Reefs 20 (1), 51-65.

Frieler, K., Meinshausen, M., Golly, A., Mengel, M., Lebek, K., Donner, S. D., HoeghGuldberg, O., 2012. Limiting global warming to $2 \mathrm{C}$ is unlikely to save most coral reefs. Nature Climate Change 3 (2), 165-170.

Glynn, P. W., 1993. Coral reef bleaching: ecological perspectives. Coral Reefs 12 (1), $1-17$.

Golbuu, Y., Victor, S., Penland, L., Idip, D., Emaurois, C., Okaji, K., Yukihira, H., Iwase, A., van Woesik, R., 2007. Palau's coral reefs show differential habitat recovery following the 1998-bleaching event. Coral Reefs 26 (2), 319-332.

Grottoli, A. G., Warner, M. E., Levas, S. J., Aschaffenburg, M. D., Schoepf, V., McGinley, M., Baumann, J., Matsui, Y., 2014. The cumulative impact of annual coral bleaching can turn some coral species winners into losers. Global change biology 20 (12), 3823-3833.

Hartmann, D., Klein Tank, A., Rusticucci, M., Alexander, L., BroİLnnimann, S., Charabi, Y., Dentener, F., Dlugokencky, E., Easterling, D., Kaplan, A., Soden, B., Thorne, P., Wild, M., Zhai, P., 2013. Observations: Atmosphere and Surface. In: Stocker, T., Qin, D., Plattner, G., Tignor, M., Allen, S., Boschung, J., Nauels, A., Xia, Y., Bex, V., Midgley, P. (Eds.), Climate Change 2013: The Physical Science Basis. Contribution of Working Group 1 to the Fifth Assessment Report of the Intergovernmental Panel on Climate Change. Cambridge University Press, Cambridge, United Kingdom and New York, NY, USA. 
Hoegh-Guldberg, O., Cai, R., Poloczanska, E., Brewer, P., Sundby, S., Helmi, K., Fabry, V., Jung, S., 2014. The Ocean. In: Barros, V., Field, C., Dokken, D., Mastrandrea, M., Mach, K., Bilir, T., Chatterjee, M., Ebi, K., Estrada, Y., Genova, R., Girma, B., Kissel, E., Levy, A., MacCracken, S., Mastrandrea, P., White, L. (Eds.), Climate Change 2014: Impacts, Adaptation, and Vulnerability. Contribution of Working Group 2 to the Fifth Assessment Report of the Intergovernmental Panel on Climate Change. Cambridge University Press, Cambridge, United Kingdom and New York, NY, USA.

Hoegh-Guldberg, O., Mumby, P. J., Hooten, A. J., Steneck, R. S., Greenfield, P., Gomez, E., Harvell, C. D., Sale, P. F., Edwards, A. J., Caldeira, K., 2007. Coral reefs under rapid climate change and ocean acidification. Science 318 (5857), 17371742.

Hudson, J. H., Shinn, E. A., Halley, R. B., Lidz, B., 1976. Sclerochronology: A tool for interpreting past environments. Geology 4 (6), 361-364.

Jokiel, P. L., Brown, E. K., oct 2004. Global warming, regional trends and inshore environmental conditions influence coral bleaching in Hawaii. Global Change Biology 10 (10), 1627-1641.

Jones, G. P., McCormick, M. I., Srinivasan, M., Eagle, J. V., 2004. Coral decline threatens fish biodiversity in marine reserves. Proceedings of the National Academy of Sciences of the United States of America 101 (21), 8251-8253.

Kalnay, E., 1996. The NCEP/NCAR 40-year reanalysis project. M eteortlingiraf Sock.

Kleypas, J. A., Castruccio, F. S., Curchitser, E. N., Mcleod, E., 2015. The impact of ENSO on coral heat stress in the western equatorial Pacific. Global change biology $21,2525-2539$.

Knowlton, N., Brainard, R. E., Fisher, R., Moews, M., Plaisance, L., Caley, M., 2010. Coral Reef Biodiversity. In: Life in the World's Oceans: Diversity, Distribution, and Abundance.

Kohler, K. E., Gill, S. M., 2006. Coral Point Count with Excel extensions (CPCe): A Visual Basic program for the determination of coral and substrate coverage using random point count methodology. Computers \& Geosciences 32 (9), 1259-1269.

Liu, B., Yang, H., Zhao, Z., Li, X., 2014. Internal solitary wave propagation observed by tandem satellites. Geophysical Research Letters 41 (6), 2077-2085.

Liu, N., Wang, H., Ling, T., Feng, L., 2013. The influence of ENSO on sea surface temperature variations in the China seas. Acta Oceanologica Sinica 32 (9), 21-29.

Mendes, J. M., Woodley, J. D., 2002. Effect of the 1995-1996 bleaching event on polyp tissue depth, growth, reproduction and skeletal band formation in Montastraea annularis. Mar. Ecol. Prog. Ser. 235, 93-102. 
NASA Goddard Space Flight Center, Ocean Ecology Lab, O. B. P. G., 2014. MODIS Aqua Ocean Color Data.

URL http://oceancolor.gsfc.nasa.gov/cms/data/aqua

Palumbi, S. R., Barshis, D. J., Traylor-Knowles, N., Bay, R. A., 2014. Mechanisms of Reef Coral Resistance to Future Climate Change. Science 344, 895-898.

Pandolfi, J. M., Connolly, S. R., Marshall, D. J., Cohen, A. L., 2011. Projecting coral reef futures under global warming and ocean acidification. Science 333 (6041), 418422.

Ray, R. D., 2013. Precise comparisons of bottom-pressure and altimetric ocean tides. Journal of Geophysical Research: Oceans 118 (9), 4570-4584.

Reed, R. K., 1976. On estimation of net long-wave radiation from the oceans. Journal of Geophysical Research 81 (33), 5793-5794.

Reynolds, R. W., Rayner, N. A., Smith, T. M., Stokes, D. C., Wang, W., 2002. An improved in situ and satellite SST analysis for climate. Journal of Climate 15 (13), $1609-1625$.

Rhein, M., Rintoul, S., Aoki, S., Campos, E., Chambers, D., Feely, R., Gulev, S., Johnson, G., Josey, S., Kostianoy, A., Mauritzen, C., Roemmich, D., Talley, L., Wang, F., 2013. Observations: Ocean. In: Stocker, T., Qin, D., Plattner, G., Tignor, M., Allen, S., Boschung, J., Nauels, A., Xia, Y., Bex, V., Midgley, P. (Eds.), Climate Change 2013: The Physical Science Basis. Contribution of Working Group 1 to the Fifth Assessment Report of the Intergovernmental Panel on Climate Change. Cambridge University Press, Cambridge, United Kingdom and New York, NY, USA.

Rong, Z., Liu, Y., Zong, H., Cheng, Y., 2007. Interannual sea level variability in the South China Sea and its response to ENSO. Global and Planetary Change 55 (4), $257-272$.

Schmidt, G. M., Wall, M., Taylor, M., Jantzen, C., Richter, C., 2016. Large-amplitude internal waves sustain coral health during thermal stress. Coral Reefs, 1-13.

Smith, T. M., Reynolds, R. W., Peterson, T. C., Lawrimore, J., 2008. Improvements to NOAA's Historical Merged Land-Ocean Surface Temperature Analysis (18802006). Journal of Climate 21 (10), 2283-2296.

Tschakert, P., 2015. 1.5 C or $2 \mathrm{C}$ : a conduit's view from the science-policy interface at COP20 in Lima, Peru. Climate Change Responses 2 (1), 11.

UNFCCC, 2015. Adoption of The Paris Agreement FCCC/CP/2015/L.9/Rev.1. Tech. rep.

URL http://unfccc.int/resource/docs/2015/cop21/eng/109r01.pdf 
van Hooidonk, R., Maynard, J. A., Planes, S., 2013. Temporary refugia for coral reefs in a warming world. Nature Climate Change 3, 508-511.

Victor, D. G., Kennel, C. F., 2014. Climate policy: Ditch the 2 C warming goal. Nature 514 (7520), 30-31.

Wall, M., Putchim, L., Schmidt, G. M., Jantzen, C., Khokiattiwong, S., Richter, C., 2015. Large-amplitude internal waves benefit corals during thermal stress. Proceedings. Biological sciences / The Royal Society 282 (1799), 9.

Wang, Y. H., Dai, C. F., Chen, Y. Y., 2007. Physical and ecological processes of internal waves on an isolated reef ecosystem in the South China Sea. Geophysical Research Letters 34 (18), L18609.

Watch, N. C. R., 2013. NOAA Coral Reef Watch Daily Global 5-km Satellite Virtual Station Time Series Data for Dongsha Atoll, Taiwan. URL http://coralreef watch. noaa.gov/vs/index.php

Wilkinson, C., 2008. Status of Coral Reefs of the World: 2008 Global Coral Reef Monitoring Network and Reef and Rainforest Research Centre. Townsville, Australia.

Wolter, K., Timlin, M. S., 2011. El Niño/Southern Oscillation behaviour since 1871 as diagnosed in an extended multivariate ENSO index (MEI.ext). International Journal of Climatology 31 (7), 1074-1087. 


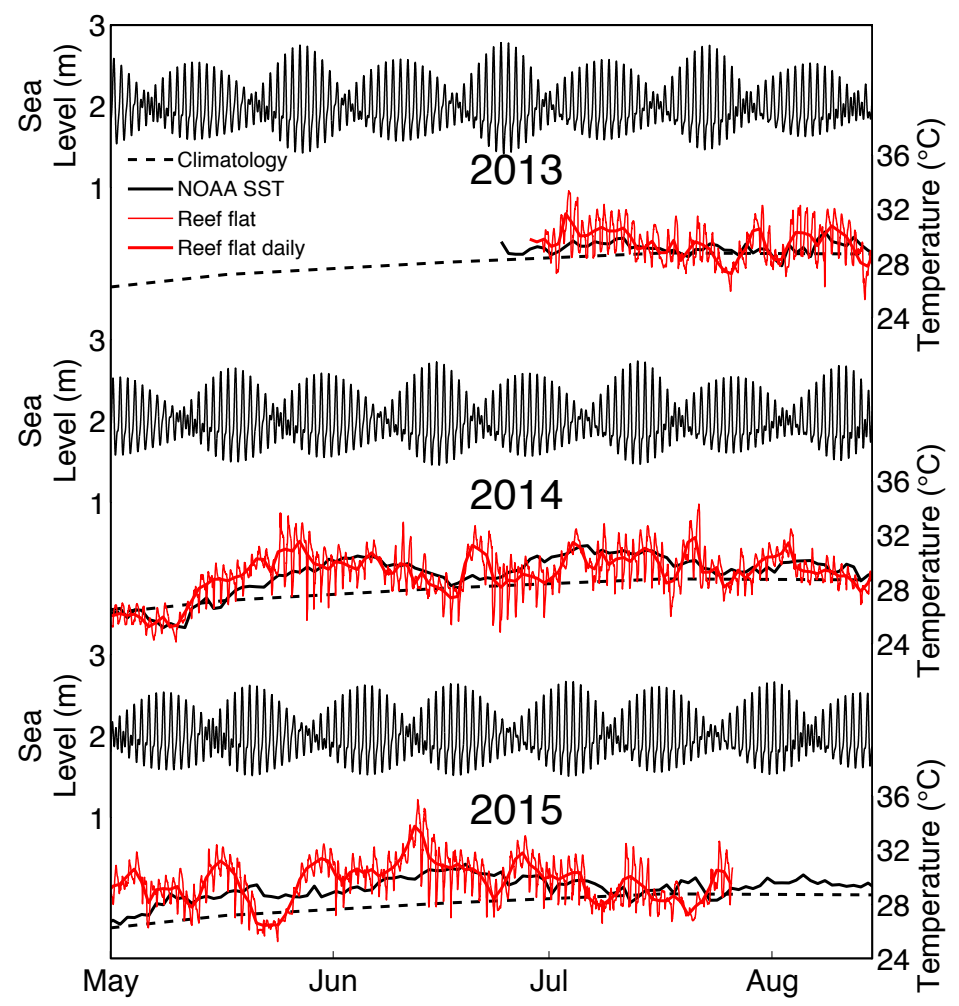

Figure 6-5: Supplemental Figure S1: Time series of summertime sea level and water temperature at station E5 on the eastern reef flat. Solid black, solid red, and dashed black plots show sea level, reef flat temperature, and SST climatology, respectively, for years 2013 (top), 2014 (middle), and 2015 (bottom). The climatology (dashed black; NOAA Coral Reef Watch $5-\mathrm{km}$ product monthly means) is the same for all temperature panels, and thus provides a baseline for comparing the reef flat temperatures (red) among years. Sea level fluctuations were estimated with the model of (Ray, 2013) and set to the mean depth $(2 \mathrm{~m})$ at station E5. Reef flat temperatures generally track the open-ocean, but often increase during neap tides (i.e. when the sea level amplitude is at a minimum). The greatest temperatures occurred in June 2015, when reef flat temperatures were consistently elevated above the open ocean for several weeks, and were superimposed on a $2{ }^{\circ} \mathrm{C}$ open-ocean anomaly. 

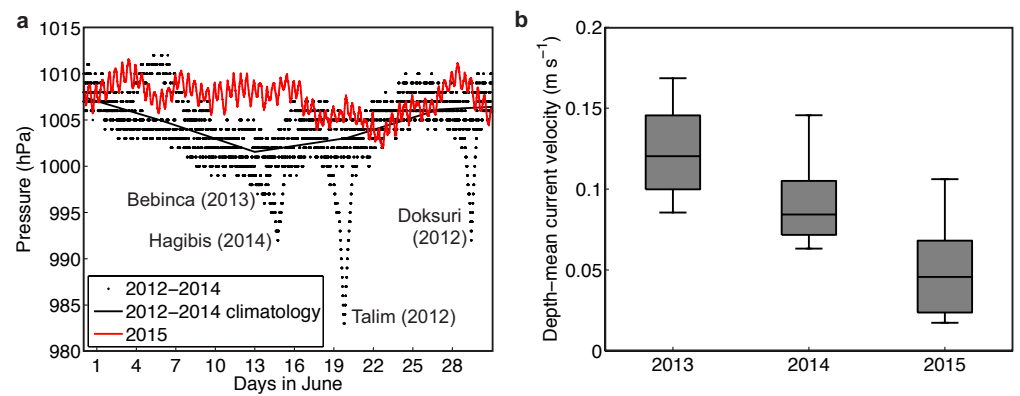

Figure 6-6: Supplemental Figure S2: Atmospheric pressure and water current anomalies in June 2015. a, June atmospheric pressure measured on Dongsha Island between 2012-2015. Atmospheric pressure in June 2015 (red) was higher than the June 20122014 climatology (black) during almost the entire month. Named tropical storms are indicated next to the associated low-pressure anomalies. b, Box plots of depth-mean current velocities measured at reef flat station E5 in June of 2013, 2014, and 2015. Horizontal black lines are median velocities, gray boxes are the interquartile ranges, and vertical bars are 10th to 90th percentiles. In a, the greatest pressure anomaly in June 2015 occurred during 8-15 June, consistent with the timing of low winds and current speeds, and the onset of bleaching. 


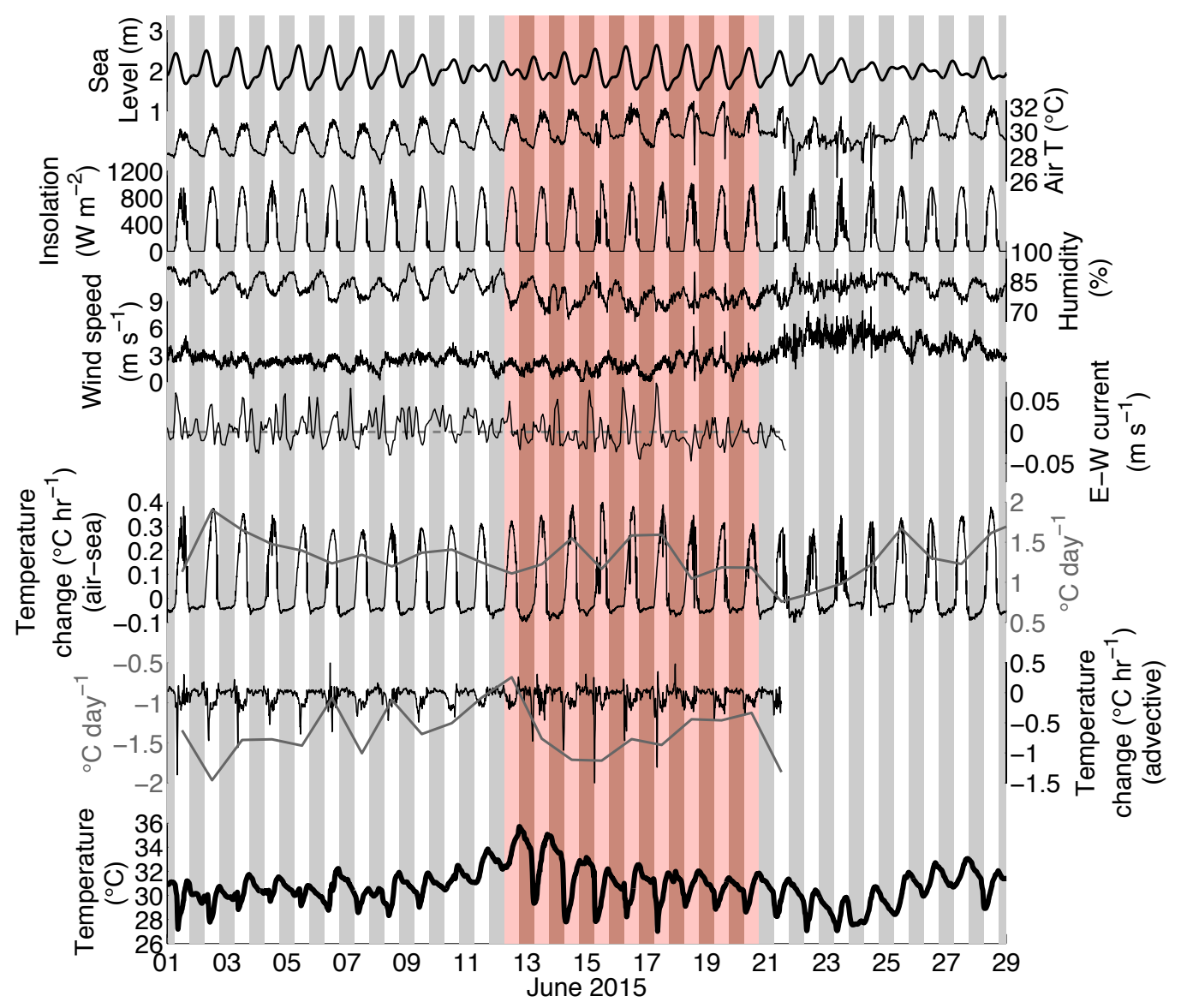

Figure 6-7: Supplemental Figure S3: Local physical conditions on the reef leading to bleaching. Time series of weather conditions on Dongsha Island, current speeds, estimated heat budget components, and measured water temperature on the reef flat. Thick gray lines in heat budget component panels show daily mean temperature changes (note different y-axis scales for daily compared to hourly data). White background is daytime, shaded background is nighttime, and red-shaded background indicates the time within which the onset of bleaching is constrained by visual observations on the reef flat (i.e. no bleaching observed on 12 June, and all corals visually bleached on 20 June). The air-sea heat flux maintains a consistent pattern throughout the first half of the month, whereas the strong cooling events in the advective component of the heat budget begin to diminish leading into the maximum reef temperatures and the onset of bleaching. 


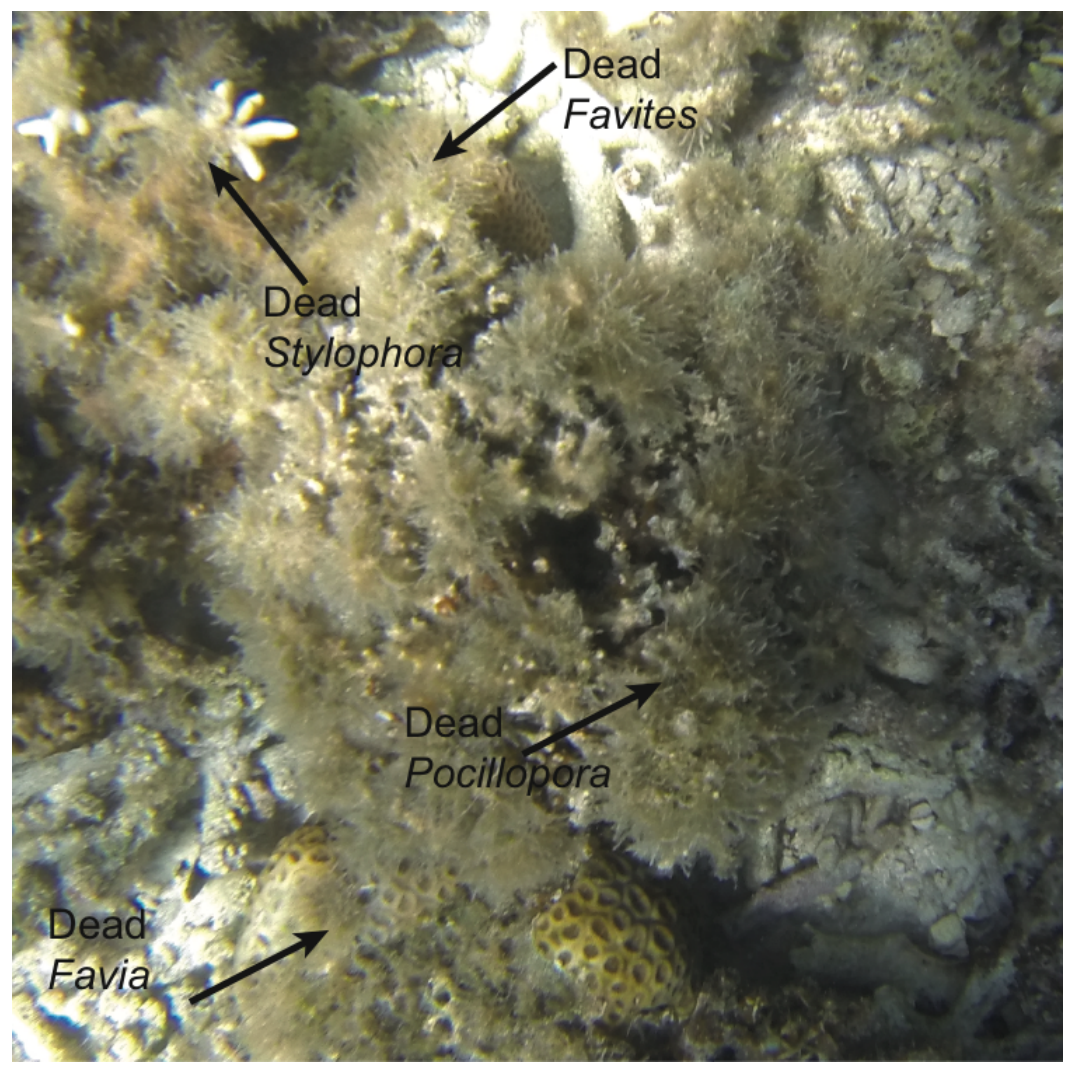

Figure 6-8: Supplemental Figure S4: Photograph from the post-bleaching ecological survey at station E5 showing how recently dead corals are partially obscured by algae. Dead or partially dead colonies of Stylophora, Favites, Favia, and Pocillopora are all present in this image, all covered with algae. While we are able to identify the recent mortality in this image, we cannot exclude the possibility that some recently dead coral colonies were hidden in post-bleaching surveys. 


\section{Chapter 7}

\section{Conclusions and Future Directions}

If global climate model (GCM) projections of $1-4{ }^{\circ} \mathrm{C}$ warming over the next century prove true, the consequences for tropical coral reef ecosystems will be devastating (Frieler et al., 2012). Some corals show signs of acclimation and adaptation (Palumbi et al., 2014), but whether corals have enough time to adjust to a warmer ocean depends on the rate of 21st century warming (van Hooidonk et al., 2013). GCMs vary greatly in their predicted warming rates, and much of this variability arises from differences in their sensitivity to anthropogenic $\mathrm{CO}_{2}$ emissions (Stocker et al., 2013; Meehl et al., 2014). Typically, GCMs are tuned to the instrumental temperature record by adjusting their sensitivity to $\mathrm{CO}_{2}$, so that historical $\mathrm{CO}_{2}$ emissions produce the historical temperature trend. However, internal variability within Earth's climate system imprints natural fluctuations - on interannual, multi-decadal, and centennial timescales - onto the observed warming trend ( $\mathrm{Li}$ et al., 2013). In comparison to natural variability, the instrumental temperature record is short; it extends back only 150 years - though for vast regions of the ocean it is reliable for less than half of this time (Giese and Ray, 2011) - and is insufficient to fully characterize the range of natural variability. This complicates efforts to ascribe the instrumental warming trend to atmospheric $\mathrm{CO}_{2}$, to tune the climate sensitivity of GCMs, and to forecast temperatures into the future.

Likewise, we have an incomplete picture of the temperatures to which coral reef ecosystems have been exposed. Reliable temperature records for large swaths of the 
tropical oceans go back only to the start of the satellite era in 1982, and pre-satellite temperatures for many coral reef areas are based on a handful of 20th century ship tracks (Giese and Ray, 2011). In the remote central Pacific Ocean, for instance, estimates of the degree of 20th century warming in the ocean surrounding coral reef ecosystems vary by a factor of two (Nurhati et al., 2011).

Corals themselves can help fill these gaps in our knowledge. Past ocean temperatures are recorded in their skeletons, but so far we have been unable to read them accurately. In Chapters 2 and 3, I show that we can reliably extract temperature information from coral skeletons, but we can only do so by characterizing coral biomineralization. I developed a new coral thermometer, "Sr-U" that offers great potential to reconstruct past climate with unprecedented accuracy. Future investigations should use Sr-U to reconstruct tropical climate changes over the past several millennia. These records would advance our understanding of the range of natural climate variability, potentially improve our estimates of climate sensitivity to $\mathrm{CO}_{2}$, and constrain the dynamics of the climate system. Coral-based reconstructions can be developed for remote stretches of the tropical oceans, regions where we have a particularly poor understanding of past climate changes. At the same time, Sr-U should be further validated. The Sr-U temperature calibration was developed for Porites and mean annual temperatures between $26^{\circ} \mathrm{C}$ and $30{ }^{\circ} \mathrm{C}$. While this calibration is applicable over much of the tropical Indo-Pacific, further validation is needed for higher latitudes, where mean annual temperatures are less than $26{ }^{\circ} \mathrm{C}$. Sr-U also needs to be validated for multiple genera, in particular the long-lived genera found in the Caribbean such as Diploria, Siderastrea, and Orbicella. Further, isotopic and elemental ratios in addition to $\mathrm{Sr} / \mathrm{Ca}$ and $\mathrm{U} / \mathrm{Ca}$ may prove valuable in reconstructing temperature. $\mathrm{B} / \mathrm{Ca}$ ratios and boron isotopic composition, in particular, are only weakly sensitive to temperature but strongly sensitive to carbonate chemistry (Holcomb et al., 2016). Coupling boron systematics with U/Ca ratios may further constrain the vital effects - driven by calcifying fluid carbonate chemistry - that must be accounted for in accurate coral paleothermometry.

In addition to understanding the past, we must forecast the future. In Chapters 5 
and 6, I show that thermal and chemical environments of coral reefs can differ greatly from the surrounding open ocean. These differences, and the driving forces behind them, should be considered in predictions of coral reef futures. I showed in Chapter 5 how coral reef community metabolism strongly modulates reef water carbonate chemistry, often creating favorable conditions for rapid daytime calcification. Diurnal changes in reef-water $\mathrm{pH}$ on Dongsha Atoll were comparable to those predicted for the open ocean by 2100. Future studies should address the relationship between $\mathrm{pH}$ changes driven by metabolism and those by anthropogenic $\mathrm{CO}_{2}$ emissions. In particular, will metabolism-driven changes in reef-water $\mathrm{pH}$ superimpose on, or override, declines in open-ocean $\mathrm{pH}$ ? Perhaps the only way to answer this question with confidence is to develop coupled time-series of reef-water $\mathrm{pH}$ and open-ocean $\mathrm{pH}$. Whereas $\mathrm{pH}$ time series in the open-ocean Atlantic and Pacific extend back a few decades, those on coral reefs are scarce and are typically months long, or at most a few years. We need to construct reef-water $\mathrm{pH}$ time series to go along with the open ocean ones. Further, new instruments are in development to autonomously record total alkalinity (TA) and dissolved inorganic carbon (DIC) time-series. If TA or DIC measurements are coupled with $\mathrm{pH}$, the full carbonate system is constrained, and if combined with current meters, all of the necessary data are available to develop multi-year time series of reef community metabolism. By tracking variations of metabolism over multiple years to decades, we will improve our understanding of the relationship between open-ocean and reef-water acidification.

Predictions of coral reef futures must also consider local physical processes that distinguish reef temperatures from those of the open ocean. Presently, the criteria for coral bleaching events are derived from NOAA's Coral Reef Watch "Bleaching Alert" (Liu et al., 2006). This warning system is widely used to estimate bleaching impacts, and it has even been coupled with GCMs to forecast the frequency of bleaching events over the remainder of this century (Frieler et al., 2012; van Hooidonk et al., 2013). However, the Bleaching Alert is based on open-ocean temperature data products that are too low-resolution to capture the locally amplified warming that can occur on shallow reefs. In Chapter 6, I show that while a modest $2{ }^{\circ} \mathrm{C}$ warming in the open- 
ocean South China Sea was insufficient to raise the Bleaching Alert, local amplification to $6{ }^{\circ} \mathrm{C}$ on the Dongsha Atoll reef flat resulted in mass bleaching and $50 \%$ mortality of the resident coral community. Assessments of reef futures over the remainder of this century, which rely upon this open-ocean warning system without regard to local processes, may therefore underestimate the risks placed upon shallow marine ecosystems by the open-ocean warming projected for next century.

Ultimately, we should build coupled physical-biogeochemical models of coral reef ecosystems. This would involve embedding local reef-scale physical models within broader ocean-atmosphere climate models. The larger-scale model provides the openocean and atmospheric boundary conditions, and the local hydrodynamic model captures the movement of water across the reef system. This approach is necessary because global climate model simulations are typically too coarse to resolve coral reefs structures. Once the physical model is in place, reef temperatures and carbonate chemistry can be integrated by parameterizing air-sea heat exchange (e.g., Chapter 6) and benthic metabolic rates (e.g., Chapter 5). This modeling framework would be especially valuable because, once validated, it could be used to predict coral reef $\mathrm{CaCO}_{3}$ budgets under various scenarios of warming, acidification, and benthic community changes. Critically, the model predictions of temperature and carbonate chemistry across reef ecosystems could be tested with field studies, and re-tuned as more in situ data become available. A simplified version of such a model already exists (Falter et al., 2013), but the biogeochemical component is presently limited by gaps in our understanding of the sensitivities of reef community metabolism to carbonate chemistry and temperature. My thesis contributes to filling these gaps by highlighting the importance of feedbacks between community metabolism and the seawater carbonate system, and the vulnerability of coral communities to localized heating. These findings move us one step closer to developing the coupled physical-biogeochemical models that would be so valuable in predicting coral reef futures. 


\section{Bibliography}

Falter, J. L., Lowe, R. J., Zhang, Z., McCulloch, M., 2013. Physical and biological controls on the carbonate chemistry of coral reef waters: effects of metabolism, wave forcing, sea level, and geomorphology. PLoS One 8 (1), e53303.

Frieler, K., Meinshausen, M., Golly, A., Mengel, M., Lebek, K., Donner, S. D., HoeghGuldberg, O., 2012. Limiting global warming to $2 \mathrm{C}$ is unlikely to save most coral reefs. Nature Climate Change 3 (2), 165-170.

Giese, B. S., Ray, S., 2011. El Niño variability in simple ocean data assimilation (SODA), 1871-2008. Journal of Geophysical Research: Oceans (1978-2012) 116 (C2), C02024.

Holcomb, M., DeCarlo, T., Gaetani, G., McCulloch, M., 2016. Factors affecting B/Ca ratios in synthetic aragonite. Chemical Geology.

Li, J., Sun, C., Jin, F., 2013. NAO implicated as a predictor of Northern Hemisphere mean temperature multidecadal variability. Geophysical Research Letters 40 (20), $5497-5502$.

Liu, G., Strong, A., Skirving, W., Arzayus, L., 2006. Overview of NOAA coral reef watch program's near-real time satellite global coral bleaching monitoring activities. Proceedings of the 10th international coral reef symposium: Okinawa.

Meehl, G. A., Teng, H., Arblaster, J. M., 2014. Climate model simulations of the observed early-2000s hiatus of global warming. Nature Climate Change 4 (10), 898-902.

Nurhati, I. S., Cobb, K. M., Di Lorenzo, E., 2011. Decadal-scale SST and salinity variations in the central tropical Pacific: Signatures of natural and anthropogenic climate change. Journal of Climate 24 (13), 3294-3308.

Palumbi, S. R., Barshis, D. J., Traylor-Knowles, N., Bay, R. A., 2014. Mechanisms of Reef Coral Resistance to Future Climate Change. Science 344, 895-898.

Stocker, T. F., Qin, D., Plattner, G. K., Tignor, M., Allen, S. K., Boschung, J., Nauels, A., Xia, Y., Bex, V., Midgley, P. M., 2013. IPCC, 2013: Summary for Policymakers. In Climate Change 2013: The Physical Science Basis. Tech. rep.

van Hooidonk, R., Maynard, J. A., Planes, S., 2013. Temporary refugia for coral reefs in a warming world. Nature Climate Change 3, 508-511. 


\section{Appendix A}

\section{Chapter 2 Steady-State Model}

The steady-state model of the calcifying fluid uses the experimentally determined partitioning of $\mathrm{U} / \mathrm{CO}_{3}^{2-}$ between seawater and aragonite to predict the $\mathrm{U} / \mathrm{Ca}$ ratio of coral skeleton as a function of the addition of alkalinity and DIC, and $\mathrm{CaCO}_{3}$ precipitation. We begin with the assumption of steady-state $U$ concentration in the calcifying fluid:

$$
z \rho \frac{d U_{\text {fluid }}}{d t}=F_{U-\text { in }}-F_{U-o u t}=0
$$

where $z$ is the length scale $(\mathrm{m})$ of the calcifying fluid defined as the volume divided by the area, $\rho$ is seawater density $\left(\mathrm{kg} \mathrm{m}^{-3}\right), \mathrm{U}$ is uranium concentration $\left(\mu \mathrm{mol} \mathrm{kg}^{-1}\right)$, $t$ is time (s), $\mathrm{F}$ is flux ( $\mu \mathrm{mol} \mathrm{m} \mathrm{m}^{-2} \mathrm{~s}^{-1}$ ) across the boundary of the calcifying fluid, and in and out are relative to the calcifying fluid. U enters the calcifying fluid only through addition of external seawater:

$$
F_{U-i n}=\frac{z \rho}{\tau} U_{s w}
$$

where $U_{s w}$ is the concentration of uranium in seawater and $\tau$ is the residence time (s) of fluid in the calcifying space. U leaves the system by removal of calcifying fluid and precipitation:

$$
F_{U-o u t}=\frac{z \rho}{\tau} U_{\text {fluid }}+P\left(\frac{U}{\mathrm{CO}_{3}}\right)_{\text {fluid }} K_{D}^{U / C O 3}
$$


where calcifying fluid density is assumed equal to seawater density, $P$ is precipitation rate $\left(\mu \mathrm{mol} \mathrm{CaCO}_{3} \mathrm{~m}^{-2} \mathrm{~s}^{-1}\right), K_{D}^{U / C O 3}$ is the experimentally determined exchange coefficient between $\mathrm{U}$ and $\mathrm{CO}_{3}$, and $\mathrm{CO}_{3}$ fluid and $U_{\text {fluid }}$ are in units of $\mu$ mol $\mathrm{kg}^{-1}$. Rearranging Eq. (A.1):

$$
F_{U-\text { in }}=F_{U-o u t}
$$

Substituting Eq. (A.2) and Eq. (A.3) into Eq. (A.4):

$$
\frac{z \rho}{\tau} U_{s w}=\frac{z \rho}{\tau} U_{\text {fluid }}+P\left(\frac{U}{C O_{3}}\right)_{f l u i d} K_{D}^{U / C O 3}
$$

where each term is expressed as a flux. Multiplying by $\tau$ and dividing by $z \rho$ in order to express each term as a concentration:

$$
U_{s w}=U_{\text {fluid }}+\frac{\tau}{z \rho} P\left(\frac{U}{C O_{3}}\right)_{f l u i d} K_{D}^{U / C O 3}
$$

We rearrange by first factoring $\left(\frac{U}{\mathrm{CO}_{3}}\right)_{\text {fluid }}$ on the right side of Eq. (A.6):

$$
U_{s w}=\left(\frac{U}{C O_{3}}\right)_{\text {fluid }}\left(C O_{3 \text { fluid }}+\frac{\tau}{z \rho} P K_{D}^{U / C O 3}\right)
$$

and then factoring $K_{D}^{U / C O 3}$ from inside the parentheses on the right side of Eq. (A.7):

$$
U_{s w}=\left(\frac{U}{C O_{3}}\right)_{f l u i d} K_{D}^{U / C O 3}\left(\frac{C O_{3 \text { fluid }}}{K_{D}^{U / C O 3}}+\frac{\tau}{z \rho} P\right)
$$

By definition:

$$
\left.\left(\frac{U}{\mathrm{CO}_{3}}\right)_{\text {Coral }}=\left(\frac{U}{\mathrm{CO}_{3}}\right)_{\text {fluid }}\right) K_{D}^{U / C O 3}
$$

Substituting Eq. (A.9) into Eq. (A.8):

$$
U_{s w}=\left(\frac{U}{C O_{3}}\right)_{C o r a l}\left(\frac{C O_{3 \text { fluid }}}{K_{D}^{U / C O 3}}+\frac{\tau}{z \rho} P\right)
$$


and rearranging to solve for $\left.\left(\frac{\mathrm{U}}{\mathrm{CO}_{3}}\right)_{\text {Coral }}\right)$ :

$$
\left(\frac{U}{C O_{3}}\right)_{C o r a l}=U_{s w}\left(\frac{C O_{3 \text { fluid }}}{K_{D}^{U / C O 3}}+\frac{\tau}{z \rho} P\right)^{-1}
$$

We follow a similar argument for $\left[\mathrm{CO}_{3}^{2-}\right]$ in the calcifying fluid by assuming $\mathrm{CO}_{3}^{2-}$ is also in steady-state. First, we assume that all alkalinity is carbonate alkalinity, and approximate $\left[\mathrm{CO}_{3}^{2-}\right]$ by the difference between the conservative properties alkalinity and DIC:

$$
C O_{3}=A_{C}-D I C
$$

where $A_{C}$ is carbonate alkalinity $\left(\mu \mathrm{eq} \mathrm{kg} \mathrm{kg}^{-1}\right)$ and $\mathrm{CO}_{3}$ and DIC are in units of $\mu \mathrm{mol}$ $\mathrm{kg}^{-1}$. The steady-state equation for $\mathrm{CO}_{3}$ is written in terms of conservative properties $A_{C}$ and DIC:

$$
z \rho \frac{d C O_{3}}{d t}=\left(F_{A_{C}-\text { in }}-F_{D I C-\text { in }}\right)-\left(F_{A_{C}-\text { out }}-F_{D I C-\text { out }}\right)=0
$$

Rearranging Eq. (A.13):

$$
F_{A_{C}-\text { in }}-F_{D I C-\text { in }}=F_{A_{C}-\text { out }}-F_{D I C-\text { out }}
$$

$A_{C}$ and DIC enter the calcifying fluid by addition of external seawater and alkalinity and DIC addition/diffusion:

$$
F_{C O_{3}-i n}=F_{A_{C}-i n}-F_{D I C-i n}=\frac{z \rho}{\tau}\left(A_{C s w}-D I C_{s w}\right)+r_{A_{C}}-r_{D I C}
$$

where $r_{A_{C}}\left(\mu \mathrm{eq} \mathrm{m}^{-2} \mathrm{~s}^{-1}\right)$ and $r_{D I C}\left(\mu \mathrm{mol} \mathrm{m} \mathrm{m}^{-2} \mathrm{~s}^{-1}\right)$ are fluxes into the calcifying fluid of $\mathrm{AC}$ and DIC, respectively. The flux of $\mathrm{CO}_{3}^{2-}$ is set equal to the difference of the flux of $A_{C}$ and DIC following Eq. (A.12) for clarity, even though we work in units of $A_{C}$ and DIC. $A_{C}$ and DIC exit the system by removal of calcifying fluid and precipitation:

$$
F_{C O_{3}-\text { out }}=F_{A_{C}-\text { out }}-F_{D I C-\text { out }}=\frac{z \rho}{\tau}\left(A_{C \text { fluid }}-D I C_{\text {fluid }}\right)+2 P-P
$$


where precipitation of aragonite removes 2 equivalents $A_{C}$ per 1 mole DIC. Substituting Eq. (A.15) and Eq. (A.16) into Eq. (A.14):

$$
\frac{z \rho}{\tau}\left(A_{C s w}-D I C_{s w}\right)+r_{A_{C}}-r_{D I C}=\frac{z \rho}{\tau}\left(A_{C \text { fluid }}-D I C_{\text {fluid }}\right)+2 P-P
$$

where each term is expressed as a flux. Multiplying by $\tau$ and dividing by $z \rho$ in order to express each term as a concentration:

$$
A_{C s w}-D I C_{s w}+\frac{\tau}{z \rho} r_{A_{C}}-\frac{\tau}{z \rho} r_{D I C}=A_{C \text { fluid }}-D I C_{f l u i d}+\frac{\tau}{z \rho} P
$$

Rearranging to solve for $A_{C \text { fluid }}-D I C_{\text {fluid }}$ and substituting Eq. (A.12):

$$
C O_{3_{\text {fluid }}}=A_{C \text { fluid }}-D I C_{\text {fluid }}=A_{C s w}-D I C_{s w}+\frac{\tau}{z \rho} r_{A_{C}}-\frac{\tau}{z \rho} r_{D I C}-\frac{\tau}{z \rho} P
$$

We assume that during steady-state, $r_{A_{C}}=2 r_{D I C}$, and define the following terms:

$$
\alpha=\frac{\tau}{z \rho} r_{A_{C}}
$$

where $\alpha$ is in units of $\mu \mathrm{eq} \mathrm{kg}^{-1}$, and

$$
\beta=\frac{2 P}{r_{A_{C}}}
$$

where $\beta$ is dimensionless and 2 appears in the numerator because 2 equivalents of alkalinity precipitate per 1 mole of $\mathrm{CaCO}_{3}$. Substituting Eq. (A.20) and Eq. (A.21) into Eq. (A.19):

$$
C O_{3_{\text {fluid }}}=A_{C s w}-D I C_{s w}+\frac{\alpha-\beta \alpha}{2}
$$

Substituting Eq. (A.22) into Eq. (10) in the main text:

$$
K_{D}^{U / C O 3}=0.14 \ln \left(A_{C s w}-D I C_{s w}+\frac{\alpha-\beta \alpha}{2}\right)-0.70
$$

Next we substitute Eqs. (A.20-23) into Eq. (A.11), and determine $\left[\mathrm{CO}_{3}\right]_{\text {Coral }}$ from 
stoichiometry:

$$
\left(\frac{U}{C a}\right)_{C o r a l}=\left(\frac{U}{C O_{3}}\right)_{C o r a l}=U_{s w}\left(\frac{A_{C s w}-D I C_{s w}+\frac{\alpha-\beta \alpha}{2}}{0.14 \ln \left(A_{C s w}-D I C_{s w}+\frac{\alpha-\beta \alpha}{2}\right)-0.70}+\frac{\beta \alpha}{2}\right)^{-1}
$$

We can now express coral $\mathrm{U} / \mathrm{Ca}$ with two degrees of freedom as $\alpha$ and $\beta$ are the only freely adjustable terms in Eq. (A.24). $\alpha$ describes the alkalinity added into the fluid during the residence time of a parcel of calcifying fluid, while $\beta$ is the ratio of alkalinity precipitation to addition. We make simplifying assumptions of initial seawater as: $A_{C s w}=2300 \mu \mathrm{eq} \mathrm{kg}^{-1} D I C_{s w}=2100 \mu \mathrm{mol} \mathrm{kg}{ }^{-1}$ Salinity $=35$

$\mathrm{U}_{S W}$ is calculated using the relationship between seawater salinity and $\mathrm{U}$ (Owens et al., 2011).

Following the same steady-state assumptions for $\mathrm{Ca}$ and assuming that alkalinity addition is coupled with Ca addition $\left(2 r_{C a}=r_{A_{C}}\right.$ where $r_{C a}$ is the Ca addition rate in $\mu \mathrm{mol} \mathrm{m} \mathrm{m}^{-2} \mathrm{~s}^{-1}$ ) to the calcifying fluid (Al-Horani et al., 2003):

$$
C a_{\text {fluid }}=C a_{s w}+\frac{\alpha-\beta \alpha}{2}
$$

Further, Sr concentration in the calcifying fluid can be calculated following a similar approach as for U, except where Sr exchanges with Ca. We also assume that the mechanism of $\mathrm{Ca}$ addition into the calcifying fluid does not discriminate against $\mathrm{Sr}$, or in other words $\mathrm{Sr}$ is added into the calcifying fluid according to the rate of alkalinity addition and the seawater $\mathrm{Sr} / \mathrm{Ca}$ ratio:

$$
r_{S r}=r_{C a}\left(\frac{S r}{C a}\right)_{s w}
$$

The $\mathrm{Sr} / \mathrm{Ca}$ ratio of the coral skeleton is:

$$
\left(\frac{S r}{C a}\right)_{C o r a l}=\left(S r_{s w}+\frac{\alpha}{2}\left(\frac{S r}{C a}\right)_{s w}\right)\left(\frac{C a_{s w}+\frac{\alpha-\beta \alpha}{2}}{K_{D}^{S r / C a}}+\frac{\beta \alpha}{2}\right)^{-1}
$$

where Eq. (A.27) is derived following similar steps as Eqs. (A.1-11 and A.24), except $\mathrm{Ca}$ replaces $\mathrm{CO}_{3}$ and the term $\left.\frac{\alpha}{2}\left(\frac{S r}{C a}\right)_{s w}\right)$ appears on the right side of Eq. 
because we assume that Sr enters the calcifying fluid via alkalinity addition (Eq. A.26), as well as from seawater flux.

The $\mathrm{pH}$ of the calcifying fluid is determined from the carbonate alkalinity and $\left[\mathrm{CO}_{3}^{2-}\right]$ of the calcifying fluid, where carbonate alkalinity is:

$$
A_{C \text { fluid }}=A_{C s w}+\alpha-\beta \alpha
$$

and $\mathrm{pH}$ is:

$$
\begin{aligned}
& p H_{\text {fluid }}=-\log _{10}\left(\left[H^{+}\right]\right)=-\log _{10}\left(\frac{K_{2}^{\prime} H C O_{3_{\text {fluid }}}}{C O_{3_{\text {fluid }}}}\right)=-\log _{10}\left(\frac{K_{2}^{\prime}\left(A_{C}=2 C O_{3}\right)_{\text {fluid }}}{C O_{3_{\text {fluid }}}}\right) \\
= & -\log _{10}\left(\frac{K_{2}^{\prime}\left(A_{C_{s w}}+\alpha-\beta \alpha-29\right)}{A_{C_{s w}}-D I C_{s w}+\frac{\alpha-\beta \alpha}{2}}\right)=-\log _{10}\left(\frac{K_{2}^{\prime}\left(-A_{C_{s w}}+2 D I C_{s w}\right)}{A_{C_{s w}}-D I C_{s w}+\frac{\alpha-\beta \alpha}{2}}\right)
\end{aligned}
$$

where $K_{2}^{\prime}$ is the apparent second dissociation constant of carbonic acid in seawater. The percent of DIC in the calcifying fluid from seawater is:

$$
\% D I C_{s w}=\left(1-\frac{\frac{\alpha}{2}}{\frac{\alpha}{2}+D I C_{s w}}\right) x 100
$$


Appendix B

Data for Chapter 2 
Table B.1: Data for Chapter 2

\begin{tabular}{|c|c|c|c|c|c|c|}
\hline experiment & $\begin{array}{l}\text { initial } \\
\text { solution } \\
\text { mass (g) }\end{array}$ & $\begin{array}{l}\text { solid } \\
\mathrm{Sr} / \mathrm{Ca} \\
(\mathrm{mmol} \\
\left.\mathrm{mol}^{-1}\right)\end{array}$ & $\begin{array}{l}\text { solid } \\
\mathrm{U} / \mathrm{Ca} \\
(\mu \mathrm{mol} \\
\left.\mathrm{mol}^{-1}\right)\end{array}$ & $\begin{array}{l}\text { final } \\
\text { solution } \\
{[\mathrm{Ca}]} \\
(\mathrm{mmol} \\
\left.\mathrm{kg}^{-1}\right)\end{array}$ & $\begin{array}{l}\text { final } \\
\text { solution } \\
{[\mathrm{Sr}]} \\
(\mu \mathrm{mol} \\
\left.\mathrm{kg}^{-1}\right)\end{array}$ & $\begin{array}{l}\text { final } \\
\text { solution } \\
{[\mathrm{U}]} \\
(\mathrm{nmol} \\
\left.\mathrm{kg}^{-1}\right)\end{array}$ \\
\hline h02 & 703.6 & 9.36 & 1.659 & 7.57 & 61.4 & 9.5 \\
\hline h08 & 699.86 & 9.47 & 1.944 & 6.25 & 48.5 & 6.2 \\
\hline f01 & 700 & 9.40 & 1.862 & 5.49 & 41.3 & 4.7 \\
\hline f02 & 699.96 & 9.38 & 2.090 & 6.89 & 55.0 & 6.9 \\
\hline f03 & 699.99 & 9.08 & 1.760 & 7.79 & 63.6 & 9.6 \\
\hline f04 & 700.2 & 9.35 & 2.192 & 6.52 & 52.0 & 6.5 \\
\hline f05 & 700.27 & 8.95 & 1.413 & 6.29 & 51.0 & 8.1 \\
\hline f06 & 796.43 & 9.28 & 2.374 & 6.00 & 46.8 & 4.4 \\
\hline f08 & 699.46 & 14.89 & 2.475 & - & - & - \\
\hline g01 & 699.99 & 9.28 & 1.917 & 6.20 & 49.5 & 6.6 \\
\hline g03 & 700.9 & 9.48 & 2.248 & 7.29 & 57.5 & 6.7 \\
\hline g04 & 699.85 & 9.24 & 2.065 & 7.54 & 60.8 & 8.8 \\
\hline g05 & 700 & 9.27 & 2.116 & 6.65 & 53.6 & 6.7 \\
\hline g06 & 600.22 & 9.39 & 2.017 & 5.93 & 45.6 & 5.9 \\
\hline g07 & 600.18 & 9.28 & 1.838 & 7.20 & 58.2 & 8.1 \\
\hline g08 & 650.2 & 9.24 & 1.816 & 6.70 & 53.9 & 7.6 \\
\hline g09 & 500.05 & 9.16 & 1.908 & 5.73 & 45.9 & 6.2 \\
\hline g10 & 399.99 & 8.79 & 1.773 & 5.26 & 40.8 & 5.1 \\
\hline g11 & 409.73 & 9.23 & 2.074 & 6.39 & 50.8 & 6.5 \\
\hline g13 & 701.92 & 13.31 & 1.989 & 8.98 & 109.6 & 2.4 \\
\hline h01 & 699.98 & 9.20 & 1.665 & 5.37 & 42.2 & 5.8 \\
\hline h09 & 399.73 & 9.09 & 1.874 & 4.97 & 38.6 & 4.1 \\
\hline h10 & 429.73 & 9.17 & 1.875 & 5.86 & 46.9 & 6.5 \\
\hline h03 & 700.11 & 9.15 & 2.283 & 6.68 & 53.4 & 6.1 \\
\hline h07 & 701.56 & 9.10 & 2.368 & 6.80 & 54.2 & 6.1 \\
\hline h05 & 700.4 & 8.78 & 2.254 & 6.50 & 52.9 & 5.7 \\
\hline h06 & 700.25 & 8.74 & 2.420 & 6.96 & 57.4 & 5.9 \\
\hline
\end{tabular}


Appendix C

Data for Chapter 3 
Table C.1: Palmyra 2

$\begin{array}{lll}\text { Date } & \mathrm{Sr} / \mathrm{Ca}\left(\mathrm{mmol} \mathrm{mol}^{-1}\right) & \mathrm{U} / \mathrm{Ca}\left(\mu \mathrm{mol} \mathrm{mol}{ }^{-1}\right) \\ 2010.00 & 8.94 & 1.26 \\ 2009.95 & 9.01 & 1.29 \\ 2009.90 & 9.00 & 1.31 \\ 2009.85 & 8.99 & 1.28 \\ 2009.80 & 9.02 & 1.27 \\ 2009.75 & 8.88 & 1.22 \\ 2009.59 & 8.98 & 1.20 \\ 2009.42 & 8.93 & 1.25 \\ 2009.25 & 9.04 & 1.18 \\ 2009.08 & 9.11 & 1.17 \\ 2008.92 & 9.05 & 1.16 \\ 2008.75 & 9.06 & 1.17 \\ 2008.59 & 9.03 & 1.19 \\ 2008.42 & 9.09 & 1.19 \\ 2008.25 & 9.04 & 1.20 \\ 2008.09 & 9.19 & 1.23 \\ 2008.01 & 9.16 & 1.22 \\ 2007.94 & 9.16 & 1.23 \\ 2007.86 & 9.14 & 1.21 \\ 2007.79 & 9.11 & 1.23 \\ 2007.71 & 9.10 & 1.22 \\ 2007.64 & 9.08 & 1.22 \\ 2007.56 & 9.07 & 1.19 \\ 2007.48 & 8.97 & 1.19 \\ 2007.41 & 9.07 & 1.20 \\ 2007.33 & 9.12 & 1.21 \\ 2007.26 & 9.03 & 1.17 \\ 2007.18 & 8.95 & 1.18 \\ 2007.10 & 9.00 & 1.17 \\ 2007.03 & 9.07 & 1.17 \\ 2006.95 & 8.94 & 1.17 \\ 2006.88 & 8.89 & 1.14 \\ 2006.80 & 8.90 & 1.08 \\ 2006.73 & 8.98 & 1.10 \\ 2006.65 & 8.94 & 1.12 \\ 2006.58 & 8.97 & 1.13 \\ 2006.50 & 8.88 & 1.16 \\ 2006.42 & 8.96 & 1.18 \\ 2006.33 & 8.96 & 1.19 \\ 2006.25 & 9.05 & 1.21 \\ & & \end{array}$


Table C.2: Palmyra 3

$\begin{array}{lll}\text { Date } & \mathrm{Sr} / \mathrm{Ca}\left(\mathrm{mmol} \mathrm{mol}^{-1}\right) & \left.\mathrm{U} / \mathrm{Ca}(\mu \mathrm{mol} \mathrm{mol})^{-1}\right) \\ 2009.84 & 8.65 & 0.90 \\ 2009.70 & 8.62 & 0.89 \\ 2009.56 & 8.83 & 0.94 \\ 2009.41 & 8.80 & 0.97 \\ 2009.27 & 8.83 & 1.01 \\ 2009.13 & 8.87 & 0.97 \\ 2008.99 & 8.85 & 0.99 \\ 2008.85 & 8.88 & 0.98 \\ 2008.71 & 8.83 & 1.02 \\ 2008.57 & 8.86 & 1.02 \\ 2008.43 & 8.92 & 1.07 \\ 2008.28 & 8.92 & 1.08 \\ 2008.14 & 8.97 & 1.10 \\ 2008.00 & 9.09 & 1.17 \\ 2007.96 & 9.05 & 1.13 \\ 2007.91 & 9.01 & 1.09 \\ 2007.87 & 8.86 & 1.01 \\ 2007.82 & 8.94 & 1.02 \\ 2007.77 & 8.91 & 1.01 \\ 2007.73 & 8.85 & 0.98 \\ 2007.68 & 8.80 & 0.99 \\ 2007.63 & 8.85 & 0.97 \\ 2007.59 & 8.78 & 0.96 \\ 2007.39 & 8.89 & 1.05 \\ 2007.20 & 8.98 & 1.04 \\ 2007.09 & 8.94 & 1.04 \\ 2006.99 & 8.93 & 1.01 \\ 2006.89 & 8.79 & 0.99 \\ 2006.79 & 8.81 & 0.99 \\ 2006.68 & 8.83 & 0.98 \\ 2006.58 & 8.77 & 0.95 \\ 2006.48 & 8.81 & 0.96 \\ 2006.37 & 8.87 & 0.98 \\ 2006.27 & 9.04 & 1.05 \\ 2006.16 & 8.93 & 0.97 \\ 2006.06 & 9.03 & 1.01 \\ 2005.96 & 8.96 & 0.99 \\ 2005.86 & 8.98 & 1.02 \\ 2005.75 & 8.80 & 0.97 \\ 2005.66 & 8.86 & 0.95 \\ & & \end{array}$


Table C.3: Palmyra 3

$\begin{array}{lll}\text { Date } & \mathrm{Sr} / \mathrm{Ca}\left(\mathrm{mmol} \mathrm{mol}^{-1}\right) & \mathrm{U} / \mathrm{Ca}\left(\mu \mathrm{mol} \mathrm{mol}^{-1}\right) \\ 2005.57 & 8.89 & 1.01 \\ 2005.48 & 8.93 & 1.02 \\ 2005.39 & 8.94 & 1.02 \\ 2005.30 & 8.98 & 1.02 \\ 2005.21 & 8.86 & 0.99 \\ 2005.12 & 8.87 & 0.95 \\ 2005.03 & 8.86 & 0.96 \\ 2004.94 & 8.90 & 0.96 \\ 2004.85 & 8.91 & 1.00 \\ 2004.76 & 8.85 & 0.98 \\ 2004.67 & 8.84 & 0.95 \\ 2004.52 & 8.86 & 0.99 \\ 2004.38 & 8.91 & 1.02 \\ 2004.23 & 8.91 & 1.03 \\ 2004.09 & 9.01 & 1.00 \\ 2003.95 & 8.93 & 0.98 \\ 2003.81 & 8.88 & 0.96 \\ 2003.67 & 8.83 & 0.97 \\ 2003.38 & 9.00 & 1.00 \\ 2003.09 & 8.92 & 1.06 \\ 2003.05 & 8.95 & 1.07 \\ 2003.01 & 8.90 & 1.06 \\ 2002.98 & 8.91 & 1.03 \\ 2002.94 & 8.90 & 1.04 \\ 2002.90 & 8.93 & 1.02 \\ 2002.87 & 8.87 & 1.04 \\ 2002.83 & 8.84 & 0.99 \\ 2002.73 & 8.68 & 0.96 \\ 2002.65 & 8.71 & 1.00 \\ 2002.57 & 8.82 & 1.01 \\ 2002.48 & 8.87 & 1.06 \\ 2002.40 & 8.94 & 1.06 \\ 2002.32 & 8.85 & 1.06 \\ 2002.24 & 8.95 & 1.07 \\ 2002.15 & 8.84 & 1.06 \\ 2002.07 & 8.86 & 1.06 \\ 2001.99 & 8.91 & 1.04 \\ 2001.91 & 8.81 & 1.01 \\ 2001.83 & 8.73 & 1.00 \\ 2001.72 & 8.78 & 1.04 \\ 2001.62 & 8.87 & 1.07 \\ & & \end{array}$


Table C.4: Palmyra 3

\begin{tabular}{|c|c|c|}
\hline Date & $\mathrm{Sr} / \mathrm{Ca}\left(\mathrm{mmol} \mathrm{mol}{ }^{-1}\right)$ & 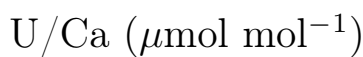 \\
\hline 2001.51 & 8.89 & 1.10 \\
\hline 2001.41 & 8.95 & 1.10 \\
\hline 2001.30 & 8.92 & 1.05 \\
\hline 2001.20 & 8.92 & 1.06 \\
\hline 2001.10 & 9.01 & 1.08 \\
\hline 2001.01 & 9.01 & 1.03 \\
\hline 2000.92 & 8.87 & 1.01 \\
\hline 2000.83 & 8.79 & 0.99 \\
\hline 2000.64 & 8.85 & 1.02 \\
\hline 2000.46 & 9.01 & 1.08 \\
\hline 2000.27 & 9.03 & 1.14 \\
\hline 2000.09 & 9.08 & 1.07 \\
\hline 1999.84 & 9.02 & 1.04 \\
\hline 1999.67 & 8.96 & 1.01 \\
\hline 1999.59 & 9.01 & 1.02 \\
\hline 1999.51 & 9.03 & 1.08 \\
\hline 1999.43 & 9.00 & 1.08 \\
\hline 1999.35 & 8.90 & 1.05 \\
\hline 1999.27 & 8.84 & 1.00 \\
\hline 1999.18 & 8.90 & 1.05 \\
\hline 1999.10 & 8.99 & 1.03 \\
\hline 1999.02 & 8.91 & 0.97 \\
\hline 1998.94 & 8.83 & 0.98 \\
\hline 1998.86 & 8.94 & 1.00 \\
\hline 1998.78 & 8.93 & 0.99 \\
\hline 1998.70 & 8.87 & 0.94 \\
\hline 1998.62 & 8.83 & 0.93 \\
\hline 1998.54 & 8.93 & 0.97 \\
\hline 1998.46 & 8.91 & 0.94 \\
\hline 1998.37 & 8.77 & 0.92 \\
\hline 1998.29 & 8.89 & 0.95 \\
\hline 1998.21 & 8.95 & 0.95 \\
\hline 1998.13 & 8.81 & 0.94 \\
\hline 1998.05 & 8.77 & 0.93 \\
\hline 1997.97 & 8.80 & 0.92 \\
\hline 1997.89 & 8.78 & 0.92 \\
\hline 1997.81 & 8.76 & 0.86 \\
\hline
\end{tabular}


Table C.5: Red Sea 44

\begin{tabular}{|c|c|c|}
\hline Date & $\mathrm{Sr} / \mathrm{Ca}\left(\mathrm{mmol} \mathrm{mol}{ }^{-1}\right)$ & $\mathrm{U} / \mathrm{Ca}\left(\mu \mathrm{mol} \mathrm{mol}^{-1}\right)$ \\
\hline 2009.92 & 8.88 & 1.09 \\
\hline 2009.88 & 9.02 & 1.16 \\
\hline 2009.84 & 9.05 & 1.21 \\
\hline 2009.81 & 9.03 & 1.15 \\
\hline 2009.77 & 8.97 & 1.15 \\
\hline 2009.73 & 8.98 & 1.18 \\
\hline 2009.69 & 8.95 & 1.14 \\
\hline 2009.65 & 8.92 & 1.10 \\
\hline 2009.62 & 8.77 & 1.08 \\
\hline 2009.58 & 8.74 & 1.06 \\
\hline 2009.54 & 8.76 & 1.06 \\
\hline 2009.50 & 8.73 & 1.03 \\
\hline 2009.43 & 8.76 & 1.07 \\
\hline 2009.36 & 8.93 & 1.12 \\
\hline 2009.30 & 8.97 & 1.16 \\
\hline 2009.23 & 8.90 & 1.14 \\
\hline 2009.16 & 8.98 & 1.16 \\
\hline 2009.09 & 9.00 & 1.14 \\
\hline 2009.00 & 8.88 & 1.10 \\
\hline 2008.92 & 8.84 & 1.08 \\
\hline 2008.84 & 8.85 & 1.10 \\
\hline 2008.75 & 8.85 & 1.11 \\
\hline 2008.67 & 8.79 & 1.10 \\
\hline 2008.48 & 8.89 & 1.11 \\
\hline 2008.29 & 9.25 & 1.32 \\
\hline 2008.11 & 9.10 & 1.27 \\
\hline 2007.92 & 9.27 & 1.26 \\
\hline 2007.84 & 9.11 & 1.24 \\
\hline 2007.75 & 9.00 & 1.24 \\
\hline 2007.67 & 9.03 & 1.25 \\
\hline 2007.59 & 8.97 & 1.23 \\
\hline 2007.39 & 9.07 & 1.25 \\
\hline 2007.20 & 9.14 & 1.25 \\
\hline 2007.00 & 9.10 & 1.27 \\
\hline 2006.96 & 9.03 & 1.25 \\
\hline 2006.91 & 9.05 & 1.23 \\
\hline 2006.86 & 8.99 & 1.24 \\
\hline 2006.81 & 8.97 & 1.23 \\
\hline 2006.77 & 8.99 & 1.22 \\
\hline
\end{tabular}


Table C.6: Red Sea 44

$\begin{array}{lll}\text { Date } & \mathrm{Sr} / \mathrm{Ca}\left(\mathrm{mmol} \mathrm{mol}^{-1}\right) & \mathrm{U} / \mathrm{Ca}\left(\mu \mathrm{mol} \mathrm{mol}{ }^{-1}\right) \\ 2006.72 & 8.95 & 1.11 \\ 2006.67 & 8.89 & 1.14 \\ 2006.53 & 9.02 & 1.22 \\ 2006.24 & 9.02 & 1.13 \\ 2006.09 & 9.18 & 1.16 \\ 2006.00 & 9.00 & 1.08 \\ 2005.92 & 8.88 & 1.06 \\ 2005.84 & 8.92 & 1.06 \\ 2005.75 & 8.90 & 1.04 \\ 2005.67 & 8.90 & 1.02 \\ 2005.57 & 8.92 & 1.04 \\ 2005.48 & 8.96 & 1.02 \\ 2005.38 & 9.01 & 1.08 \\ 2005.28 & 9.08 & 1.11 \\ 2005.19 & 9.05 & 1.07 \\ 2005.09 & 9.09 & 1.07\end{array}$

Table C.7: Red Sea 1

$\begin{array}{lll}\text { Date } & \mathrm{Sr} / \mathrm{Ca}\left(\mathrm{mmol} \mathrm{mol}^{-1}\right) & \mathrm{U} / \mathrm{Ca}\left(\mu \mathrm{mol} \mathrm{mol}^{-1}\right) \\ 2009.92 & 9.00 & 1.12 \\ 2009.81 & 9.06 & 1.28 \\ 2009.71 & 9.00 & 1.08 \\ 2009.60 & 8.87 & 1.06 \\ 2009.50 & 8.94 & 1.05 \\ 2009.39 & 8.91 & 1.03 \\ 2009.28 & 8.98 & 1.08 \\ 2009.18 & 9.03 & 1.10 \\ 2009.07 & 8.97 & 1.05 \\ 2008.96 & 8.99 & 1.05 \\ 2008.86 & 9.08 & 1.13 \\ 2008.75 & 9.11 & 1.10 \\ 2008.64 & 9.04 & 1.10 \\ 2008.54 & 8.93 & 1.07 \\ 2008.43 & 8.93 & 1.05 \\ 2008.33 & 8.87 & 1.05 \\ 2008.22 & 8.84 & 1.13 \\ 2008.11 & 9.00 & 1.25 \\ 2008.01 & 8.98 & 1.27 \\ 2007.90 & 9.17 & 1.44\end{array}$


Table C.8: Red Sea 1

$\begin{array}{lll}\text { Date } & \mathrm{Sr} / \mathrm{Ca}\left(\mathrm{mmol} \mathrm{mol}^{-1}\right) & \mathrm{U} / \mathrm{Ca}\left(\mu \mathrm{mol} \mathrm{mol}{ }^{-1}\right) \\ 2007.80 & 9.15 & 1.33 \\ 2007.69 & 9.14 & 1.17 \\ 2007.59 & 9.02 & 1.15 \\ 2007.48 & 9.01 & 1.10 \\ 2007.37 & 8.70 & 1.05 \\ 2007.27 & 8.76 & 1.06 \\ 2007.16 & 8.79 & 1.08 \\ 2007.05 & 8.83 & 1.07 \\ 2006.95 & 8.91 & 1.09 \\ 2006.84 & 9.02 & 1.14 \\ 2006.73 & 8.96 & 1.12 \\ 2006.63 & 8.98 & 1.12 \\ 2006.52 & 9.03 & 1.12 \\ 2006.42 & 9.01 & 1.12 \\ 2006.31 & 9.01 & 1.12 \\ 2006.20 & 9.10 & 1.14 \\ 2006.09 & 9.08 & 1.17 \\ 2005.99 & 8.97 & 1.16 \\ 2005.88 & 8.96 & 1.15 \\ 2005.78 & 9.00 & 1.13 \\ 2005.67 & 9.03 & 1.07 \\ 2005.57 & 9.09 & 1.10 \\ 2005.46 & 9.22 & 1.15 \\ 2005.35 & 9.24 & 1.18 \\ 2005.25 & 9.13 & 1.11 \\ 2005.14 & 9.03 & 1.05 \\ 2005.03 & 8.92 & 1.04 \\ 2004.93 & 8.89 & 1.06 \\ 2004.82 & 8.98 & 1.07 \\ 2004.72 & 9.07 & 1.14 \\ 2004.61 & 9.07 & 1.12 \\ 2004.50 & 9.06 & 1.09 \\ 2004.40 & 9.14 & 1.11 \\ 2004.29 & 9.28 & 1.16 \\ 2004.18 & 9.23 & 1.13 \\ 2004.08 & 9.15 & 1.10 \\ 2003.97 & 8.99 & 1.11 \\ 2003.87 & 9.04 & 1.22 \\ 2003.76 & 8.99 & 1.11 \\ 2003.66 & 9.04 & 1.10 \\ 2003.55 & 9.19 & 1.18 \\ 2003.44 & 9.18 & 1.16 \\ & & \end{array}$


Table C.9: Red Sea 1

$\begin{array}{lll}\text { Date } & \mathrm{Sr} / \mathrm{Ca}\left(\mathrm{mmol} \mathrm{mol}^{-1}\right) & \mathrm{U} / \mathrm{Ca}\left(\mu \mathrm{mol} \mathrm{mol}{ }^{-1}\right) \\ 2003.34 & 9.20 & 1.17 \\ 2003.23 & 9.07 & 1.09 \\ 2003.12 & 8.93 & 1.09 \\ 2003.02 & 8.94 & 1.05 \\ 2002.91 & 8.94 & 1.09 \\ 2002.81 & 8.96 & 1.11 \\ 2002.70 & 8.96 & 1.06 \\ 2002.59 & 9.03 & 1.09 \\ 2002.49 & 9.04 & 1.06 \\ 2002.38 & 9.07 & 1.09 \\ 2002.27 & 9.13 & 1.10 \\ 2002.17 & 8.98 & 1.07 \\ 2002.06 & 9.11 & 1.22 \\ 2001.96 & 9.09 & 1.20 \\ 2001.85 & 8.98 & 1.08 \\ 2001.74 & 8.96 & 1.06 \\ 2001.64 & 8.98 & 1.08 \\ 2001.53 & 9.04 & 1.14 \\ 2001.42 & 9.04 & 1.16 \\ 2001.32 & 9.13 & 1.24 \\ 2001.21 & 9.07 & 1.13 \\ 2001.10 & 8.99 & 1.16 \\ 2001.00 & 8.96 & 1.13 \\ 2000.89 & 8.96 & 1.08 \\ 2000.79 & 9.01 & 1.10 \\ 2000.68 & 9.00 & 1.08 \\ 2000.57 & 9.04 & 1.10 \\ 2000.47 & 8.89 & 1.02 \\ 2000.36 & 9.03 & 1.04 \\ 2000.26 & 9.10 & 1.08 \\ 2000.15 & 9.12 & 1.11 \\ 2000.04 & 9.15 & 1.09 \\ 1999.94 & 9.02 & 1.08 \\ 1999.83 & 8.97 & 1.06 \\ 1999.73 & 8.97 & 1.10 \\ 1999.62 & 9.04 & 1.16 \\ 1999.51 & 8.96 & 1.10 \\ 1999.41 & 8.98 & 1.06 \\ 1999.30 & 9.00 & 1.08 \\ 1999.20 & 9.08 & 1.10 \\ 1999.09 & 9.01 & 1.12 \\ 1998.98 & 9.01 & 1.10 \\ & & \end{array}$


Table C.10: Red Sea 1

$\begin{array}{lll}\text { Date } & \mathrm{Sr} / \mathrm{Ca}\left(\mathrm{mmol} \mathrm{mol}^{-1}\right) & \mathrm{U} / \mathrm{Ca}\left(\mu \mathrm{mol} \mathrm{mol}^{-1}\right) \\ 1998.88 & 8.91 & 1.10 \\ 1998.77 & 8.97 & 1.17 \\ 1998.66 & 9.00 & 1.17 \\ 1998.56 & 8.95 & 1.08 \\ 1998.45 & 8.98 & 1.07 \\ 1998.35 & 8.92 & 1.06 \\ 1998.24 & 8.97 & 1.16 \\ 1998.13 & 9.01 & 1.18 \\ 1998.02 & 9.12 & 1.16 \\ 1997.92 & 9.06 & 1.09\end{array}$

Table C.11: Palau 23

$\begin{array}{lll}\text { Date } & \mathrm{Sr} / \mathrm{Ca}\left(\mathrm{mmol} \mathrm{mol}^{-1}\right) & \mathrm{U} / \mathrm{Ca}\left(\mu \mathrm{mol} \mathrm{mol}{ }^{-1}\right) \\ 2000.00 & 8.75 & 0.99 \\ 1999.97 & 8.85 & 0.99 \\ 1999.95 & 8.77 & 0.97 \\ 1999.92 & 8.82 & 0.99 \\ 1999.89 & 8.85 & 1.01 \\ 1999.86 & 8.78 & 1.02 \\ 1999.84 & 8.71 & 1.03 \\ 1999.78 & 8.91 & 1.02 \\ 1999.75 & 8.92 & 1.01 \\ 1999.73 & 8.77 & 0.98 \\ 1999.70 & 8.77 & 0.98 \\ 1999.67 & 8.84 & 0.97 \\ 1999.64 & 8.81 & 1.01 \\ 1999.62 & 8.81 & 0.99 \\ 1999.59 & 8.77 & 0.96 \\ 1999.56 & 8.95 & 1.02 \\ 1999.53 & 8.99 & 1.02 \\ 1999.51 & 8.96 & 1.00 \\ 1999.48 & 8.92 & 1.03 \\ 1999.45 & 8.90 & 0.99 \\ 1999.42 & 8.92 & 0.97 \\ 1999.39 & 8.88 & 0.98 \\ 1999.37 & 8.98 & 1.01 \\ 1999.34 & 8.86 & 0.98 \\ 1999.31 & 8.92 & 0.98\end{array}$


Table C.12: Palau 23

$\begin{array}{lll}\text { Date } & \mathrm{Sr} / \mathrm{Ca}\left(\mathrm{mmol} \mathrm{mol}^{-1}\right) & \mathrm{U} / \mathrm{Ca}\left(\mu \mathrm{mol} \mathrm{mol}^{-1}\right) \\ 1999.28 & 8.85 & 1.01 \\ 1999.26 & 8.93 & 1.02 \\ 1999.23 & 8.86 & 1.03 \\ 1999.20 & 8.88 & 1.04 \\ 1999.17 & 9.00 & 1.08 \\ 1999.14 & 8.84 & 1.05 \\ 1999.12 & 8.84 & 1.05 \\ 1999.09 & 8.88 & 1.01 \\ 1999.06 & 8.89 & 1.01 \\ 1999.03 & 8.90 & 1.02 \\ 1999.01 & 8.93 & 1.00 \\ 1998.97 & 8.92 & 1.03 \\ 1998.93 & 8.84 & 1.02 \\ 1998.90 & 8.86 & 1.02 \\ 1998.86 & 8.94 & 1.04 \\ 1998.82 & 8.84 & 1.02 \\ 1998.78 & 8.89 & 1.03 \\ 1998.75 & 8.84 & 1.03 \\ 1998.71 & 8.80 & 1.00 \\ 1998.67 & 8.82 & 0.99 \\ 1998.62 & 8.82 & 1.02 \\ 1998.56 & 8.88 & 1.00 \\ 1998.51 & 8.81 & 1.03 \\ 1998.45 & 8.81 & 1.02 \\ 1998.39 & 8.90 & 1.15 \\ 1998.34 & 8.92 & 1.13 \\ 1998.28 & 8.92 & 1.07 \\ 1998.23 & 8.90 & 1.03 \\ 1998.17 & 8.94 & 1.08 \\ 1998.08 & 8.87 & 1.04 \\ 1998.00 & 8.86 & 1.04 \\ 1997.92 & 8.94 & 1.04 \\ 1997.87 & 8.90 & 1.02 \\ 1997.82 & 8.85 & 0.98 \\ 1997.77 & 8.78 & 0.97 \\ 1997.76 & 8.80 & 1.00 \\ 1997.74 & 8.84 & 1.04 \\ 1997.72 & 8.89 & 1.06 \\ 1997.70 & 8.90 & 1.04 \\ 1997.68 & 8.99 & 1.07 \\ 1997.66 & 8.96 & 1.12 \\ 1997.64 & 9.04 & 1.11 \\ & & \end{array}$


Table C.13: Palau 23

$\begin{array}{lll}\text { Date } & \mathrm{Sr} / \mathrm{Ca}\left(\mathrm{mmol} \mathrm{mol}^{-1}\right) & \mathrm{U} / \mathrm{Ca}\left(\mu \mathrm{mol} \mathrm{mol}{ }^{-1}\right) \\ 1997.63 & 9.00 & 1.08 \\ 1997.61 & 9.00 & 1.09 \\ 1997.59 & 9.08 & 1.12 \\ 1997.57 & 9.03 & 1.11 \\ 1997.56 & 8.92 & 1.12 \\ 1997.54 & 8.92 & 1.07 \\ 1997.52 & 8.93 & 1.09 \\ 1997.50 & 8.92 & 1.08 \\ 1997.49 & 8.93 & 1.11 \\ 1997.47 & 8.91 & 1.06 \\ 1997.45 & 8.87 & 1.07 \\ 1997.44 & 8.87 & 1.04 \\ 1997.42 & 8.93 & 1.09 \\ 1997.40 & 8.88 & 1.07 \\ 1997.39 & 8.75 & 1.04 \\ 1997.37 & 8.91 & 1.06 \\ 1997.35 & 8.85 & 1.05 \\ 1997.34 & 8.91 & 1.09 \\ 1997.32 & 8.88 & 1.08 \\ 1997.30 & 8.82 & 1.06 \\ 1997.29 & 8.84 & 1.04 \\ 1997.27 & 8.90 & 1.08 \\ 1997.25 & 8.88 & 1.08 \\ 1997.24 & 8.91 & 1.10 \\ 1997.22 & 8.94 & 1.11 \\ 1997.20 & 8.92 & 1.11 \\ 1997.19 & 9.01 & 1.14 \\ 1997.17 & 9.01 & 1.14\end{array}$

Table C.14: Palau 180

Date $\quad \mathrm{Sr} / \mathrm{Ca}\left(\mathrm{mmol} \mathrm{mol}^{-1}\right) \quad \mathrm{U} / \mathrm{Ca}\left(\mu \mathrm{mol} \mathrm{mol}^{-1}\right)$ $2002.08 \quad 8.82$ 1.29

$\begin{array}{lll}2002.02 & 8.88 & 1.30\end{array}$

$\begin{array}{lll}2001.96 & 8.81 & 1.26\end{array}$

$\begin{array}{lll}2001.91 & 8.83 & 1.28\end{array}$

$\begin{array}{lll}2001.85 & 8.86 & 1.22\end{array}$

$\begin{array}{lll}2001.79 & 8.85 & 1.24\end{array}$

$\begin{array}{lll}2001.73 & 8.90 & 1.26\end{array}$

$\begin{array}{lll}2001.67 & 8.95 & 1.24\end{array}$

$\begin{array}{lll}2001.61 & 8.87 & 1.25\end{array}$

$\begin{array}{lll}2001.54 & 8.89 & 1.24\end{array}$ 
Table C.15: Palau 180

$\begin{array}{lll}\text { Date } & \mathrm{Sr} / \mathrm{Ca}\left(\mathrm{mmol} \mathrm{mol}^{-1}\right) & \mathrm{U} / \mathrm{Ca}\left(\mu \mathrm{mol} \mathrm{mol}^{-1}\right) \\ 2001.46 & 9.00 & 1.27 \\ 2001.38 & 9.06 & 1.28 \\ 2001.29 & 9.01 & 1.30 \\ 2001.21 & 8.93 & 1.24 \\ 2001.15 & 8.97 & 1.25 \\ 2001.12 & 9.05 & 1.30 \\ 2001.08 & 8.96 & 1.30 \\ 2001.05 & 9.02 & 1.34 \\ 2001.02 & 9.06 & 1.28 \\ 2000.99 & 8.89 & 1.26 \\ 2000.96 & 9.06 & 1.23 \\ 2000.92 & 9.10 & 1.31 \\ 2000.89 & 9.07 & 1.28 \\ 2000.86 & 9.10 & 1.28 \\ 2000.83 & 8.90 & 1.19 \\ 2000.80 & 8.92 & 1.26 \\ 2000.76 & 8.95 & 1.25 \\ 2000.73 & 8.94 & 1.25 \\ 2000.70 & 8.91 & 1.24 \\ 2000.67 & 9.03 & 1.25 \\ 2000.63 & 9.05 & 1.26 \\ 2000.60 & 8.93 & 1.21 \\ 2000.55 & 8.85 & 1.26 \\ 2000.49 & 8.86 & 1.24 \\ 2000.42 & 8.93 & 1.21 \\ 2000.36 & 8.86 & 1.24 \\ 2000.30 & 8.92 & 1.21 \\ 2000.23 & 8.91 & 1.21 \\ 2000.17 & 8.97 & 1.22 \\ 2000.11 & 9.03 & 1.27 \\ 2000.04 & 8.92 & 1.22 \\ 1999.98 & 9.00 & 1.20 \\ 1999.92 & 8.95 & 1.24 \\ 1999.86 & 8.92 & 1.20 \\ 1999.80 & 8.94 & 1.23 \\ 1999.74 & 8.81 & 1.23 \\ 1999.68 & 8.84 & 1.21 \\ 1999.62 & 8.86 & 1.18 \\ 1999.55 & 8.91 & 1.16 \\ 1999.48 & 8.91 & 1.17 \\ 1999.41 & 8.82 & 1.16 \\ & & \end{array}$


Table C.16: Palau 180

$\begin{array}{lll}\text { Date } & \mathrm{Sr} / \mathrm{Ca}\left(\mathrm{mmol} \mathrm{mol}^{-1}\right) & \mathrm{U} / \mathrm{Ca}\left(\mu \mathrm{mol} \mathrm{mol}{ }^{-1}\right) \\ 1999.34 & 8.83 & 1.12 \\ 1999.27 & 8.98 & 1.16 \\ 1999.20 & 9.00 & 1.21 \\ 1999.13 & 9.02 & 1.25 \\ 1999.00 & 9.08 & 1.35 \\ 1998.94 & 9.16 & 1.42 \\ 1998.88 & 9.05 & 1.35 \\ 1998.81 & 8.95 & 1.28 \\ 1998.72 & 9.05 & 1.27 \\ 1998.65 & 8.96 & 1.28 \\ 1998.59 & 8.89 & 1.32 \\ 1998.52 & 8.90 & 1.34 \\ 1998.46 & 8.88 & 1.22 \\ 1998.39 & 8.84 & 1.17 \\ 1998.33 & 8.74 & 1.15 \\ 1998.26 & 8.77 & 1.17 \\ 1998.20 & 8.81 & 1.13 \\ 1998.13 & 8.87 & 1.14 \\ 1998.07 & 8.90 & 1.12 \\ 1998.00 & 8.85 & 1.16 \\ 1997.94 & 8.87 & 1.16 \\ 1997.88 & 8.85 & 1.19 \\ 1997.81 & 8.74 & 1.17 \\ 1997.75 & 8.78 & 1.18 \\ 1997.68 & 8.82 & 1.17 \\ 1997.62 & 8.89 & 1.17 \\ 1997.55 & 8.81 & 1.15 \\ 1997.49 & 8.92 & 1.19 \\ 1997.42 & 8.91 & 1.11 \\ 1997.36 & 8.88 & 1.11 \\ 1997.30 & 8.89 & 1.17 \\ 1997.23 & 8.87 & 1.16 \\ 1997.17 & 8.92 & 1.18 \\ 1997.07 & 8.82 & 1.18 \\ 1996.99 & 8.95 & 1.20 \\ 1996.90 & 8.80 & 1.16 \\ 1996.81 & 8.87 & 1.16 \\ 1996.72 & 8.89 & 1.19 \\ 1996.63 & 8.91 & 1.30 \\ 1996.56 & 9.03 & 1.36 \\ & & \end{array}$


Table C.17: Palau 180

$\begin{array}{lll}\text { Date } & \mathrm{Sr} / \mathrm{Ca}\left(\mathrm{mmol} \mathrm{mol}^{-1}\right) & \mathrm{U} / \mathrm{Ca}\left(\mu \mathrm{mol} \mathrm{mol}^{-1}\right) \\ 1996.50 & 8.90 & 1.34 \\ 1996.44 & 8.93 & 1.36 \\ 1996.38 & 8.96 & 1.23 \\ 1996.32 & 8.85 & 1.21 \\ 1996.26 & 8.94 & 1.18 \\ 1996.20 & 8.88 & 1.20 \\ 1996.11 & 8.90 & 1.23 \\ 1995.99 & 8.95 & 1.19 \\ 1995.88 & 8.91 & 1.21 \\ 1995.76 & 8.87 & 1.18 \\ 1995.64 & 8.92 & 1.22 \\ 1995.57 & 9.03 & 1.25 \\ 1995.53 & 8.99 & 1.25 \\ 1995.49 & 9.05 & 1.22 \\ 1995.45 & 9.00 & 1.19 \\ 1995.41 & 9.10 & 1.26 \\ 1995.38 & 9.09 & 1.25 \\ 1995.34 & 9.17 & 1.25 \\ 1995.30 & 9.16 & 1.25 \\ 1995.28 & 9.02 & 1.23 \\ 1995.26 & 9.05 & 1.23 \\ 1995.22 & 8.96 & 1.18 \\ 1995.19 & 8.97 & 1.23 \\ 1995.14 & 8.96 & 1.23 \\ 1995.09 & 8.94 & 1.30 \\ 1995.03 & 8.99 & 1.29 \\ 1994.98 & 9.00 & 1.32 \\ 1994.93 & 9.03 & 1.30 \\ 1994.88 & 9.02 & 1.29 \\ 1994.82 & 8.96 & 1.25 \\ 1994.77 & 8.93 & 1.27 \\ 1994.72 & 8.99 & 1.30 \\ 1994.67 & 8.96 & 1.32 \\ 1994.61 & 8.93 & 1.30 \\ 1994.55 & 8.98 & 1.23 \\ 1994.48 & 9.03 & 1.25 \\ & & \end{array}$


Table C.18: Palau 168

$\begin{array}{lllll}\text { Date } & \mathrm{Sr} / \mathrm{Ca}\left(\mathrm{mmol} \mathrm{mol}^{-1}\right) & \mathrm{U} / \mathrm{Ca}\left(\mu \mathrm{mol} \mathrm{mol}^{-1}\right) & \delta^{11}(\%) & \mathrm{pH} \\ 2010.00 & 8.64 & 0.90 & 22.73 & 8.366 \\ 2009.80 & 8.67 & 0.99 & 22.35 & 8.341 \\ 2009.60 & 8.69 & 1.01 & 22.72 & 8.366 \\ 2009.40 & 8.67 & 0.90 & 23.00 & 8.385 \\ 2009.20 & 8.74 & 0.92 & 22.49 & 8.351 \\ 2009.00 & 8.57 & 0.84 & 22.71 & 8.365 \\ 2008.83 & 8.67 & 0.98 & 22.59 & 8.357 \\ 2008.67 & 8.58 & 1.00 & 22.35 & 8.342 \\ 2008.50 & 8.68 & 0.90 & 22.59 & 8.357 \\ 2008.33 & 8.73 & 0.94 & 22.79 & 8.371 \\ 2008.17 & 8.64 & 0.92 & 22.71 & 8.365 \\ 2008.00 & 8.67 & 0.94 & 22.61 & 8.359 \\ 2007.80 & 8.75 & 1.00 & 22.96 & 8.382 \\ 2007.60 & 8.56 & 0.95 & 23.02 & 8.386\end{array}$

Table C.19: Palau 169

$\begin{array}{lllll}\text { Date } & \mathrm{Sr} / \mathrm{Ca}\left(\mathrm{mmol} \mathrm{mol}^{-1}\right) & \mathrm{U} / \mathrm{Ca}\left(\mu \mathrm{mol} \mathrm{mol}^{-1}\right) & \delta^{11}(\%) & \mathrm{pH}_{E C F} \\ 2010.00 & 8.81 & 1.02 & 22.26 & 8.335 \\ 2009.89 & 8.68 & 1.01 & 22.15 & 8.328 \\ 2009.78 & 8.71 & 0.96 & 22.20 & 8.331 \\ 2009.67 & 8.68 & 0.97 & 22.27 & 8.336 \\ 2009.56 & 8.66 & 1.04 & 22.27 & 8.336 \\ 2009.44 & 8.74 & 1.06 & 22.42 & 8.346 \\ 2009.33 & 8.80 & 1.09 & 22.01 & 8.318 \\ 2009.22 & 8.79 & 1.10 & 22.14 & 8.327 \\ 2009.11 & 8.65 & 1.09 & 22.45 & 8.348 \\ 2009.00 & 8.67 & 1.03 & 22.56 & 8.355 \\ 2008.86 & 8.68 & 1.04 & 22.61 & 8.359 \\ 2008.71 & 8.75 & 1.06 & 22.67 & 8.362 \\ 2008.57 & 8.69 & 1.04 & 22.60 & 8.358 \\ 2008.43 & 8.71 & 0.98 & 22.63 & 8.360 \\ 2008.29 & 8.67 & 0.99 & 22.67 & 8.363 \\ 2008.14 & 8.68 & 1.01 & 22.41 & 8.345 \\ 2008.00 & 8.63 & 1.00 & 22.68 & 8.364\end{array}$


Table C.20: Palau 221

$\begin{array}{lllll}\text { Date } & \mathrm{Sr} / \mathrm{Ca}\left(\mathrm{mmol} \mathrm{mol}^{-1}\right) & \mathrm{U} / \mathrm{Ca}\left(\mu \mathrm{mol} \mathrm{mol}^{-1}\right) & \delta^{11}(\%) & \mathrm{pH}_{E C F} \\ 2010.00 & 8.68 & 1.01 & 23.98 & 8.449 \\ 2009.83 & 8.68 & 1.00 & 23.75 & 8.434 \\ 2009.67 & 8.54 & 0.96 & 24.13 & 8.458 \\ 2009.50 & 8.63 & 0.98 & 23.75 & 8.433 \\ 2009.33 & 8.65 & 0.96 & 23.48 & 8.416 \\ 2009.17 & 8.70 & 0.97 & 23.46 & 8.414 \\ 2009.00 & 8.62 & 0.93 & 23.56 & 8.421 \\ 2008.83 & 8.63 & 0.96 & 23.66 & 8.427 \\ 2008.67 & 8.67 & 0.96 & 23.69 & 8.430 \\ 2008.50 & 8.69 & 0.97 & 23.49 & 8.417 \\ 2008.33 & 8.67 & 0.94 & 24.11 & 8.457 \\ 2008.17 & 8.71 & 1.00 & 24.03 & 8.451 \\ 2008.00 & 8.66 & 0.96 & 23.66 & 8.428\end{array}$

Table C.21: Palau 229

$\begin{array}{lllll}\text { Date } & \mathrm{Sr} / \mathrm{Ca}\left(\mathrm{mmol} \mathrm{mol}^{-1}\right) & \mathrm{U} / \mathrm{Ca}\left(\mu \mathrm{mol} \mathrm{mol}^{-1}\right) & \delta^{11}(\%) & \mathrm{pH}_{E C F} \\ 2010.00 & 8.81 & 1.02 & 23.11 & 8.392 \\ 2009.89 & 8.74 & 1.01 & 23.20 & 8.398 \\ 2009.78 & 8.78 & 1.04 & 23.64 & 8.426 \\ 2009.67 & 8.72 & 1.02 & 23.31 & 8.405 \\ 2009.56 & 8.73 & 1.04 & 23.08 & 8.390 \\ 2009.44 & 8.75 & 1.06 & 22.95 & 8.381 \\ 2009.33 & 8.81 & 1.05 & 23.16 & 8.395 \\ 2009.22 & 8.81 & 1.05 & 23.37 & 8.409 \\ 2009.11 & 8.69 & 1.02 & 23.49 & 8.417 \\ 2009.00 & 8.87 & 1.03 & 23.70 & 8.430 \\ 2008.83 & 8.85 & 1.07 & 23.42 & 8.412 \\ 2008.67 & 8.94 & 1.11 & 23.78 & 8.436 \\ 2008.50 & 8.86 & 1.06 & 23.78 & 8.435 \\ 2008.33 & 8.93 & 1.07 & 23.30 & 8.404 \\ 2008.17 & 9.03 & 1.10 & 23.83 & 8.439 \\ 2008.00 & 8.89 & 1.08 & 23.36 & 8.408\end{array}$


Appendix D

Data for Chapter 4 
Table D.1: Data for Chapter 4

\begin{tabular}{|c|c|c|c|c|}
\hline Core ID & $\begin{array}{l}\text { Reef } \\
\text { site }\end{array}$ & $\begin{array}{l}\text { mean } \\
\text { calcification } \\
\text { rate } \\
\left(\mathrm{g} \mathrm{cm}^{-2} \mathrm{yr}^{-1}\right)\end{array}$ & $\begin{array}{l}\text { mean } \\
\text { density } \\
\left(\mathrm{g} \mathrm{cm}^{-3}\right)\end{array}$ & $\begin{array}{l}\text { boring } \\
\text { percent } \\
\text { by } \\
\text { volume }\end{array}$ \\
\hline Nikko 178 & Nikko Bay & - & 0.89 & 0.52 \\
\hline Nikko 181 & Nikko Bay & - & 0.92 & 0.02 \\
\hline Nikko 266 & Nikko Bay & 1.03 & 1.10 & 3.77 \\
\hline Nikko 267 & Nikko Bay & 0.99 & 1.05 & 1.36 \\
\hline Nikko 268 & Nikko Bay & 0.83 & 0.90 & 0.00 \\
\hline Nikko 269 & Nikko Bay & 0.87 & 0.81 & 0.62 \\
\hline Nikko 270 & Nikko Bay & 0.97 & 0.91 & 0.11 \\
\hline Nikko 320 & Nikko Bay & - & 0.94 & 0.00 \\
\hline Nikko 322 & Nikko Bay & - & 0.83 & 0.49 \\
\hline Nikko 180 & Nikko Bay & - & 0.96 & 0.37 \\
\hline Nikko 166 & Nikko Bay & 0.82 & 1.22 & 3.55 \\
\hline Nikko 167 & Nikko Bay & 0.93 & 1.14 & 0.52 \\
\hline Nikko 168 & Nikko Bay & 1.29 & 1.21 & 7.49 \\
\hline Nikko P & Nikko Bay & - & 0.93 & 2.61 \\
\hline Nikko 169 & Nikko Bay & 0.73 & 1.17 & 6.08 \\
\hline Nikko N & Nikko Bay & - & 1.09 & 4.44 \\
\hline Nikko O & Nikko Bay & 0.38 & 0.86 & 0.00 \\
\hline Risong 222B & Risong & - & 1.20 & 3.82 \\
\hline Risong 224 & Risong & - & 0.91 & 0.01 \\
\hline Risong 271 & Risong & 1.09 & 1.07 & 0.02 \\
\hline Risong 272 & Risong & 0.88 & 1.24 & 1.09 \\
\hline Risong 275 & Risong & 0.85 & 1.01 & 0.43 \\
\hline Risong 276 & Risong & 0.91 & 0.97 & 5.91 \\
\hline Risong 212Q & Risong & - & 1.01 & 0.63 \\
\hline Risong 213S & Risong & 0.68 & 1.17 & 0.31 \\
\hline Risong 219L & Risong & 0.81 & 1.00 & 0.00 \\
\hline Risong 222U & Risong & 0.65 & 1.13 & 0.07 \\
\hline Risong 223R & Risong & 1.14 & 1.27 & 0.00 \\
\hline Risong $224 \mathrm{~T}$ & Risong & 1.12 & 1.03 & 0.15 \\
\hline Risong 2160 & Risong & 1.09 & 1.27 & 0.00 \\
\hline Risong 217 & Risong & 0.49 & 1.13 & 4.66 \\
\hline Risong 218 & Risong & 0.65 & 1.01 & 1.72 \\
\hline Risong 225 & Risong & 0.80 & 1.09 & 1.30 \\
\hline Risong $220 \mathrm{~K}$ & Risong & 0.96 & 1.34 & 2.38 \\
\hline Risong 277 & Risong & 0.73 & 1.12 & 0.00 \\
\hline Airai 278 & Airai & 1.29 & 1.28 & 0.01 \\
\hline Airai 318 & Airai & - & 1.16 & 0.00 \\
\hline Airai 278 & Airai & - & 1.20 & 0.50 \\
\hline
\end{tabular}


Table D.2: Data for Chapter 4

\begin{tabular}{|c|c|c|c|c|}
\hline Core ID & $\begin{array}{l}\text { Reef } \\
\text { site }\end{array}$ & $\begin{array}{l}\text { mean } \\
\text { calcification } \\
\text { rate } \\
\left(\mathrm{g} \mathrm{cm}^{-2} \mathrm{yr}^{-1}\right)\end{array}$ & $\begin{array}{l}\text { mean } \\
\text { density } \\
\left(\mathrm{g} \mathrm{cm}^{-3}\right)\end{array}$ & $\begin{array}{l}\text { boring } \\
\text { percent } \\
\text { by } \\
\text { volume }\end{array}$ \\
\hline Airai A & Airai & - & 1.29 & 0.00 \\
\hline Airai B & Airai & 1.30 & 1.35 & 0.00 \\
\hline Airai C & Airai & 1.89 & 1.28 & 0.00 \\
\hline Airai 23 & Airai & 1.97 & 1.20 & 0.00 \\
\hline DropOff 325 & Uchelbeluu & 1.11 & 1.28 & 0.00 \\
\hline DropOff 210D & Uchelbeluu & 0.77 & 1.37 & 0.00 \\
\hline DropOff 214 & Uchelbeluu & 0.89 & 1.36 & 0.00 \\
\hline DropOff 221 & Uchelbeluu & 1.42 & 1.50 & 0.00 \\
\hline DropOff 229 & Uchelbeluu & 1.06 & 1.35 & 0.00 \\
\hline DropOff 230 & Uchelbeluu & 0.99 & 1.44 & 0.00 \\
\hline DropOff 231 & Uchelbeluu & 1.24 & 1.38 & 0.00 \\
\hline DropOff $232 \mathrm{~F}$ & Uchelbeluu & 0.81 & 1.44 & 0.00 \\
\hline DropOff 233B & Uchelbeluu & 0.87 & 1.40 & 0.00 \\
\hline DropOff 234I & Uchelbeluu & 0.82 & 1.38 & 0.00 \\
\hline DropOff 235J & Uchelbeluu & 1.22 & 1.29 & 0.00 \\
\hline DropOff $214 \mathrm{~A}$ & Uchelbeluu & - & 1.23 & 0.00 \\
\hline Uelbeluu 176 & Uchelbeluu & - & 1.37 & 0.00 \\
\hline Uchelbeluu 211 & Uchelbeluu & 1.78 & 1.22 & 0.00 \\
\hline Uchelbeluu $221 \mathrm{G}$ & Uchelbeluu & 1.31 & 1.50 & 0.00 \\
\hline Uchelbeluu 237 & Uchelbeluu & 1.86 & 1.28 & 0.00 \\
\hline Uchelbeluu 240D & Uchelbeluu & 0.99 & 1.23 & 0.00 \\
\hline Uchelbeluu 241E & Uchelbeluu & - & 1.23 & 0.00 \\
\hline Uchelbeluu 242 & Uchelbeluu & - & 1.30 & 0.00 \\
\hline Uchelbeluu 244 & Uchelbeluu & 0.93 & 1.31 & 0.00 \\
\hline Uchelbeluu J & Uchelbeluu & - & 1.24 & 0.89 \\
\hline Uchelbeluu 239 & Uchelbeluu & 1.31 & 1.37 & 1.45 \\
\hline Eu 279 & Uchelbeluu & 1.69 & 1.32 & 0.00 \\
\hline Eu 280 & Uchelbeluu & - & 1.37 & 0.00 \\
\hline ROS01 \#1 & Rose Atoll & 1.18 & 1.25 & 0.00 \\
\hline ROS02 $\# 2$ & Rose Atoll & 0.85 & 1.13 & 0.00 \\
\hline ROS03 \#3 & Rose Atoll & 1.04 & 1.38 & 0.00 \\
\hline ROS04 \#4 & Rose Atoll & - & 1.54 & 0.00 \\
\hline WAK $05 \# 2$ & Wake Atoll & - & 1.40 & 0.00 \\
\hline WAK 08 \#1 & Wake Atoll & - & 1.51 & 0.00 \\
\hline PAL01 \#11 & Palmyra Atoll & 1.64 & 1.17 & 0.00 \\
\hline PAL02 \#12 & Palmyra Atoll & 1.60 & 1.22 & 0.00 \\
\hline PAL03 \#13 & Palmyra Atoll & 1.56 & 1.30 & 0.00 \\
\hline KIN01 \#14 & Kingman Reef & 2.22 & 1.02 & 0.00 \\
\hline
\end{tabular}


Table D.3: Data for Chapter 4

$\begin{array}{lllll}\text { Core ID } & \begin{array}{l}\text { Reef } \\ \text { site }\end{array} & \begin{array}{l}\text { mean } \\ \text { calcification } \\ \text { rate } \\ \left(\mathrm{g} \mathrm{cm}^{-2} \mathrm{yr}^{-1}\right)\end{array} & \begin{array}{l}\text { mean } \\ \text { density } \\ \left(\mathrm{g} \mathrm{cm}^{-3}\right)\end{array} & \begin{array}{l}\text { boring } \\ \text { percent } \\ \text { by }\end{array} \\ \text { volume } \\ \text { KIN02 \#15 } & \text { Kingman Reef } & 1.60 & 1.11 & 0.00 \\ \text { KIN04 \#17 } & \text { Kingman Reef } & 1.94 & 1.13 & 0.00 \\ \text { KIN05 \#18 } & \text { Kingman Reef } & 1.58 & 1.19 & 0.00 \\ \text { KIN-P-019 } & \text { Kingman Reef } & - & 1.00 & 0.47 \\ \text { KIN-H-021 } & \text { Kingman Reef } & 1.46 & 1.18 & 1.59 \\ \text { KIN_H_022 } & \text { Kingman Reef } & 1.88 & 0.90 & 0.00 \\ \text { KIN-P-020 } & \text { Kingman Reef } & 2.09 & 1.07 & 0.00 \\ \text { KIN03 } & \text { Kingman Reef } & - & 1.16 & 0.00 \\ \text { JAR01 \#5 } & \text { Jarvis Island } & 1.36 & 1.14 & 1.10 \\ \text { JAR02 \#6 } & \text { Jarvis Island } & - & 1.38 & 6.16 \\ \text { JAR03 \#7 } & \text { Jarvis Island } & 1.65 & 1.14 & 0.00 \\ \text { JAR05 \#9 } & \text { Jarvis Island } & - & 1.47 & 8.30 \\ \text { JAR06 \#10 } & \text { Jarvis Island } & - & 1.33 & 0.06 \\ \text { JAR-H-018 } & \text { Jarvis Island } & - & 1.00 & 0.00 \\ \text { JAR-H-017 } & \text { Jarvis Island } & 0.97 & 1.30 & 0.94 \\ \text { JAR-P-016 } & \text { Jarvis Island } & 1.12 & 1.35 & 0.57 \\ \text { Pearl POR 193A } & \text { Pearl Islands } & 1.30 & 1.04 & 7.43 \\ \text { Pearl POR 193B } & \text { Pearl Islands } & 1.09 & 0.96 & 8.25 \\ \text { Pearl POR 202 } & \text { Pearl Islands } & 0.94 & 1.14 & 8.30 \\ \text { Pearl POR 192 } & \text { Pearl Islands } & 0.88 & 1.14 & 6.47 \\ \text { Pearl POR 198 } & \text { Pearl Islands } & 0.76 & 1.22 & 8.71 \\ \text { Pearl POR 200 } & \text { Pearl Islands } & 0.54 & 1.02 & 4.49 \\ \text { Pearl POR 201 } & \text { Pearl Islands } & 1.47 & 0.94 & 2.14 \\ \text { Taboga POR 188B } & \text { Taboga } & - & 0.84 & 1.94 \\ \text { Taboga POR 190 } & \text { Taboga } & - & 0.78 & 7.07 \\ \text { Taboga POR 188A } & \text { Taboga } & - & 1.03 & 11.08 \\ \text { Taboga POR 189B } & \text { Taboga } & - & 0.94 & 7.29\end{array}$


Appendix E

Data for Chapter 5 
Table E.1: Data for Chapter 5

\begin{tabular}{|c|c|c|c|c|c|c|c|}
\hline $\begin{array}{l}\text { RAS } \\
\text { sample } \\
\text { time (UTC) }\end{array}$ & $\begin{array}{l}\text { Residence } \\
\text { time } \\
(\mathrm{hr})\end{array}$ & $1 \sigma$ & Salinity & $T\left({ }^{\circ} \mathrm{C}\right)$ & $\begin{array}{l}\text { PAR } \\
(\mu \mathrm{mol} \\
\left.\mathrm{m}^{-2} \mathrm{~s}^{-1}\right)\end{array}$ & $\begin{array}{l}\text { Density } \\
\left(\mathrm{kg} \mathrm{m}^{-3}\right)\end{array}$ & $\begin{array}{l}\text { mean } \\
\text { depth } \\
(\mathrm{m})\end{array}$ \\
\hline $6 / 3 / 140: 00$ & 3.9 & 0.7 & 34.13 & 28.40 & 112 & 1021.5 & 0.97 \\
\hline $6 / 3 / 142: 00$ & 4.4 & 0.3 & 34.07 & 28.61 & 444 & 1021.4 & 1.29 \\
\hline $6 / 3 / 144: 00$ & 5.5 & 0.3 & 34.05 & 29.18 & 785 & 1021.2 & 1.39 \\
\hline $6 / 3 / 146: 00$ & 6.5 & 0.3 & 34.03 & 29.75 & 963 & 1021.0 & 1.40 \\
\hline $6 / 4 / 140: 00$ & 3.6 & 0.3 & 34.07 & 28.03 & 77 & 1021.6 & 1.10 \\
\hline $6 / 4 / 142: 00$ & 3.8 & 0.3 & 34.01 & 28.46 & 246 & 1021.4 & 1.28 \\
\hline $6 / 4 / 144: 00$ & 4.9 & 0.3 & 34.00 & 28.86 & 426 & 1021.3 & 1.39 \\
\hline $6 / 4 / 146: 00$ & 4.9 & 0.3 & 33.99 & 29.77 & 771 & 1021.0 & 1.30 \\
\hline $6 / 5 / 140: 00$ & 3.7 & 0.6 & 34.05 & 28.47 & 151 & 1021.4 & 1.00 \\
\hline $6 / 5 / 142: 00$ & 3.9 & 0.3 & 33.87 & 29.60 & 590 & 1020.9 & 1.23 \\
\hline $6 / 5 / 144: 00$ & 4.8 & 0.2 & 33.89 & 30.34 & 980 & 1020.7 & 1.35 \\
\hline $6 / 5 / 146: 00$ & 6.2 & 0.2 & 33.91 & 31.14 & 1122 & 1020.4 & 1.37 \\
\hline $6 / 6 / 142: 00$ & 5.4 & 0.7 & 34.03 & 30.21 & 348 & 1020.8 & 1.14 \\
\hline $6 / 6 / 144: 00$ & 6.3 & 0.5 & 34.04 & 30.77 & 572 & 1020.7 & 1.25 \\
\hline $6 / 6 / 146: 00$ & 7.6 & 0.4 & 34.02 & 31.23 & 724 & 1020.5 & 1.29 \\
\hline $6 / 6 / 148: 00$ & 7.7 & 0.7 & 34.05 & 31.42 & 826 & 1020.4 & 1.20 \\
\hline $6 / 10 / 144: 00$ & 7.2 & 0.2 & 32.44 & 30.00 & 697 & 1019.8 & 1.24 \\
\hline 6/10/14 6:00 & 3.6 & 0.6 & 32.48 & 31.24 & 1346 & 1019.4 & 1.26 \\
\hline $6 / 10 / 14$ 8:00 & 4.1 & 0.2 & 32.25 & 32.17 & 1125 & 1018.9 & 0.89 \\
\hline 6/10/14 12:00 & 3.2 & 0.2 & 32.18 & 30.31 & 86 & 1019.5 & 0.99 \\
\hline 6/10/14 14:00 & 4.1 & 0.3 & 32.52 & 29.27 & 8 & 1020.1 & 0.95 \\
\hline 6/10/14 16:00 & 4.9 & 0.4 & 32.64 & 28.86 & 0 & 1020.3 & 0.98 \\
\hline 6/10/14 18:00 & 5.0 & 0.3 & 32.74 & 28.47 & 0 & 1020.5 & 0.97 \\
\hline 6/10/14 20:00 & 2.4 & 0.3 & 33.21 & 27.73 & 0 & 1021.1 & 1.11 \\
\hline 6/10/14 22:00 & 1.7 & 0.1 & 33.20 & 28.43 & 9 & 1020.8 & 1.41 \\
\hline $6 / 11 / 14$ 0:00 & 2.7 & 0.1 & 33.22 & 29.10 & 218 & 1020.6 & 1.54 \\
\hline $6 / 11 / 142: 00$ & 4.3 & 0.1 & 33.21 & 29.45 & 492 & 1020.5 & 1.56 \\
\hline $6 / 11 / 144: 00$ & 5.5 & 0.2 & 33.21 & 30.16 & 783 & 1020.3 & 1.30 \\
\hline $6 / 11 / 146: 00$ & 4.2 & 0.9 & 33.21 & 31.06 & 1206 & 1019.9 & 1.14 \\
\hline $6 / 11 / 148: 00$ & 3.7 & 0.4 & 33.25 & 31.60 & 1043 & 1019.8 & 0.88 \\
\hline 6/11/14 10:00 & 4.0 & 0.5 & 33.28 & 31.89 & 585 & 1019.7 & 0.75 \\
\hline 6/11/14 14:00 & 3.9 & 0.3 & 33.36 & 28.72 & 4 & 1020.8 & 0.90 \\
\hline 6/11/14 16:00 & 4.1 & 0.4 & 33.38 & 28.07 & 0 & 1021.1 & 0.92 \\
\hline 6/11/14 18:00 & 3.4 & 0.4 & 33.40 & 28.03 & 0 & 1021.1 & 0.95 \\
\hline 6/11/14 20:00 & 2.4 & 0.2 & 33.47 & 28.21 & 0 & 1021.1 & 1.11 \\
\hline $6 / 11 / 1422: 00$ & 1.3 & 0.1 & 33.49 & 28.43 & 7 & 1021.0 & 1.51 \\
\hline $6 / 12 / 140: 00$ & 1.8 & 0.1 & 33.50 & 28.65 & 137 & 1021.0 & 1.64 \\
\hline $6 / 12 / 142: 00$ & 2.2 & 0.1 & 33.50 & 28.82 & 444 & 1020.9 & 1.49 \\
\hline $6 / 12 / 144: 00$ & 2.4 & 0.1 & 33.51 & 28.84 & 360 & 1020.9 & 1.24 \\
\hline
\end{tabular}


Table E.2: Data for Chapter 5

$\begin{array}{llllllll}\begin{array}{l}\text { RAS } \\ \text { sample }\end{array} & \begin{array}{l}\text { Residence } \\ \text { time }\end{array} & 1 \sigma & \text { Salinity } & T\left({ }^{\circ} \mathrm{C}\right) & \begin{array}{l}\text { PAR } \\ (\mu \mathrm{mol}\end{array} & \begin{array}{l}\text { Density } \\ \left(\mathrm{kg} \mathrm{m}^{-3}\right)\end{array} & \begin{array}{l}\text { mean } \\ \text { depth } \\ (\mathrm{hr})\end{array} \\ \text { 6/12/14 6:00 } & 2.1 & 0.1 & 33.55 & 28.66 & 322 & 1021.0 & 0.85 \\ \text { 6/12/14 8:00 } & 1.7 & 0.1 & 33.56 & 28.37 & 295 & 1021.1 & 0.65 \\ \text { 6/12/14 12:00 } & 1.6 & 0.1 & 33.28 & 28.05 & 8 & 1021.0 & 0.71 \\ \text { 6/12/14 14:00 } & 1.9 & 0.1 & 33.34 & 28.01 & 0 & 1021.1 & 0.84 \\ \text { 6/12/14 16:00 } & 2.0 & 0.2 & 33.57 & 28.07 & 0 & 1021.2 & 0.92 \\ \text { 6/12/14 18:00 } & 2.0 & 0.1 & 33.62 & 27.99 & 0 & 1021.3 & 0.92 \\ \text { 6/12/14 20:00 } & 2.0 & 0.1 & 33.72 & 28.14 & 0 & 1021.3 & 1.01 \\ \text { 6/12/14 22:00 } & 1.7 & 0.1 & 33.71 & 28.43 & 5 & 1021.2 & 1.42 \\ \text { 6/13/14 0:00 } & 1.43 & 0.05 & 33.87 & 28.87 & 226 & 1021.2 & 1.65 \\ \text { 6/13/14 2:00 } & 2.4 & 0.1 & 33.85 & 29.20 & 551 & 1021.0 & 1.74 \\ \text { 6/13/14 4:00 } & 3.8 & 0.1 & 33.81 & 29.72 & 794 & 1020.8 & 1.56 \\ \text { 6/13/14 6:00 } & 3.4 & 0.3 & 33.78 & 30.23 & 912 & 1020.7 & 1.14 \\ \text { 6/13/14 8:00 } & 2.1 & 0.2 & 33.77 & 30.53 & 686 & 1020.5 & 0.71 \\ \text { 6/13/14 10:00 } & 3.0 & 0.4 & 33.73 & 30.55 & 354 & 1020.5 & 0.66 \\ \text { 6/13/14 14:00 } & 1.9 & 0.1 & 33.30 & 28.02 & 0 & 1021.0 & 0.70 \\ \text { 6/13/14 16:00 } & 2.1 & 0.1 & 33.80 & 27.86 & 0 & 1021.4 & 0.84 \\ \text { 6/13/14 18:00 } & 1.9 & 0.2 & 33.88 & 27.58 & 0 & 1021.6 & 0.82 \\ \text { 6/13/14 20:00 } & 1.8 & 0.1 & 33.94 & 27.23 & 0 & 1021.8 & 0.95 \\ \text { 6/13/14 22:00 } & 1.7 & 0.1 & 33.89 & 27.90 & 5 & 1021.5 & 1.27 \\ \text { 6/14/14 0:00 } & 1.4 & 0.1 & 33.82 & 27.45 & 140 & 1021.6 & 1.56 \\ \text { 6/14/14 2:00 } & 1.49 & 0.06 & 33.78 & 28.37 & 649 & 1021.3 & 1.68\end{array}$


Table E.3: Data for Chapter 5

\begin{tabular}{|c|c|c|c|c|c|c|}
\hline $\begin{array}{l}\text { RAS } \\
\text { sample } \\
\text { time (UTC) }\end{array}$ & $\begin{array}{l}\text { TA } \\
\left(\mu \mathrm{eq} \mathrm{kg}^{-1}\right)\end{array}$ & $\begin{array}{l}\text { DIC } \\
\left(\mu \mathrm{mol} \mathrm{kg}{ }^{-1}\right)\end{array}$ & $\begin{array}{l}\mathrm{F}_{\mathrm{CO}_{2}} \\
(\mathrm{mmol} \\
\mathrm{m}^{-2} \\
\left.\mathrm{hr}^{-1}\right)\end{array}$ & $\begin{array}{l}\text { NEC } \\
(\mathrm{mmol} \\
\mathrm{m}^{-2} \\
\left.\mathrm{hr}^{-1}\right)\end{array}$ & $1 \sigma$ & $\begin{array}{l}\text { NEP } \\
(\mathrm{mmol} \\
\mathrm{m}^{-2} \\
\left.\mathrm{hr}^{-1}\right)\end{array}$ \\
\hline $6 / 3 / 140: 00$ & 2223 & 2133 & 9.9 & 4 & 2 & -62 \\
\hline 6/3/14 2:00 & 2188 & 2012 & 3.5 & 9 & 2 & -34 \\
\hline 6/3/14 4:00 & 2151 & 1892 & 0.4 & 13 & 2 & -1 \\
\hline 6/3/14 6:00 & 2111 & 1777 & -1.2 & 15 & 2 & 21 \\
\hline 6/4/14 0:00 & 2252 & 2132 & 4.0 & 0 & 3 & -64 \\
\hline 6/4/14 2:00 & 2206 & 1977 & 0.9 & 7 & 3 & -21 \\
\hline 6/4/14 4:00 & 2176 & 1904 & 0.2 & 10 & 2 & -1 \\
\hline 6/4/14 6:00 & 2110 & 1743 & -0.9 & 18 & 2 & 35 \\
\hline 6/5/14 0:00 & 2223 & 2091 & 3.1 & 3 & 2 & -48 \\
\hline 6/5/14 2:00 & 2183 & 1947 & 0.5 & 8 & 3 & -15 \\
\hline 6/5/14 4:00 & 2151 & 1819 & -0.3 & 12 & 2 & 19 \\
\hline 6/5/14 6:00 & 2110 & 1726 & -0.4 & 14 & 2 & 32 \\
\hline 6/6/14 2:00 & 2168 & 2012 & 2.9 & 8 & 2 & -27 \\
\hline 6/6/14 4:00 & 2130 & 1916 & 1.3 & 12 & 2 & -9 \\
\hline 6/6/14 6:00 & 2104 & 1854 & 0.6 & 12 & 2 & 2 \\
\hline $6 / 6 / 148: 00$ & 2091 & 1806 & 0.2 & 12 & 2 & 9 \\
\hline 6/10/14 4:00 & 2077 & 1746 & -0.8 & 6 & 1 & 13 \\
\hline 6/10/14 6:00 & 1983 & 1571 & -2.3 & 29 & 5 & 73 \\
\hline 6/10/14 8:00 & 1893 & 1411 & -3.0 & 26 & 2 & 72 \\
\hline 6/10/14 12:00 & 2052 & 1731 & -0.9 & 11 & 3 & 21 \\
\hline 6/10/14 14:00 & 2104 & 1878 & 0.3 & 5 & 2 & -12 \\
\hline 6/10/14 16:00 & 2125 & 1937 & 1.2 & 3 & 2 & -20 \\
\hline 6/10/14 18:00 & 2106 & 1842 & 2.1 & 5 & 2 & -3 \\
\hline 6/10/14 20:00 & 2182 & 1984 & 1.2 & 2 & 4 & -47 \\
\hline $6 / 10 / 1422: 00$ & 2190 & 1933 & 0.6 & 1 & 7 & -38 \\
\hline 6/11/14 0:00 & 2167 & 1898 & 0.2 & 7 & 5 & -11 \\
\hline $6 / 11 / 142: 00$ & 2139 & 1835 & -0.6 & 10 & 3 & 12 \\
\hline $6 / 11 / 144: 00$ & 2112 & 1744 & -1.4 & 10 & 2 & 27 \\
\hline $6 / 11 / 146: 00$ & 2009 & 1568 & -2.3 & 25 & 6 & 66 \\
\hline 6/11/14 8:00 & 1899 & 1442 & -3.2 & 36 & 4 & 78 \\
\hline 6/11/14 10:00 & 1717 & 1203 & -4.6 & 46 & 6 & 91 \\
\hline 6/11/14 14:00 & 2083 & 1834 & 0.6 & 14 & 2 & 1 \\
\hline 6/11/14 16:00 & 2183 & 2016 & 5.9 & 2 & 2 & -35 \\
\hline 6/11/14 18:00 & 2191 & 2053 & 6.5 & 2 & 2 & -52 \\
\hline 6/11/14 20:00 & 2196 & 2012 & 2.8 & 3 & 4 & -57 \\
\hline 6/11/14 22:00 & 2208 & 1943 & 1.0 & 1 & 10 & -45 \\
\hline 6/12/14 0:00 & 2208 & 1921 & 0.9 & 2 & 7 & -15 \\
\hline 6/12/14 2:00 & 2155 & 1861 & -1.1 & 19 & 6 & 13 \\
\hline 6/12/14 4:00 & 2128 & 1800 & -1.9 & 22 & 4 & 37 \\
\hline
\end{tabular}


Table E.4: Data for Chapter 5

\begin{tabular}{|c|c|c|c|c|c|c|}
\hline $\begin{array}{l}\text { RAS } \\
\text { sample } \\
\text { time (UTC) }\end{array}$ & $\begin{array}{l}\text { TA } \\
\left(\mu \mathrm{eq} \mathrm{kg}^{-1}\right)\end{array}$ & $\begin{array}{l}\text { DIC } \\
\left(\mu \mathrm{mol} \mathrm{kg}{ }^{-1}\right)\end{array}$ & $\begin{array}{l}\mathrm{F}_{\mathrm{CO}_{2}} \\
(\mathrm{mmol} \\
\mathrm{m}^{-2} \\
\left.\mathrm{hr}^{-1}\right)\end{array}$ & $\begin{array}{l}\text { NEC } \\
(\mathrm{mmol} \\
\mathrm{m}^{-2} \\
\left.\mathrm{hr}^{-1}\right)\end{array}$ & $1 \sigma$ & $\begin{array}{l}\text { NEP } \\
(\mathrm{mmol} \\
\mathrm{m}^{-2} \\
\left.\mathrm{hr}^{-1}\right)\end{array}$ \\
\hline 6/12/14 6:00 & 2081 & 1744 & -3.3 & 28 & 4 & 45 \\
\hline 6/12/14 8:00 & 2040 & 1695 & -4.1 & 35 & 4 & 55 \\
\hline 3/12/14 12:00 & 2127 & 1915 & 5.6 & 16 & 4 & -31 \\
\hline 6/12/14 14:00 & 2165 & 1980 & 8.6 & 8 & 4 & -54 \\
\hline 6/12/14 16:00 & 2189 & 1992 & 8.5 & 6 & 4 & -52 \\
\hline 6/12/14 18:00 & 2185 & 2006 & 8.9 & 8 & 4 & -61 \\
\hline 6/12/14 20:00 & 2206 & 1990 & 6.0 & 5 & 4 & -48 \\
\hline 6/12/14 22:00 & 2205 & 1961 & 3.1 & 9 & 7 & -48 \\
\hline 6/13/14 0:00 & 2204 & 1929 & 0.9 & 19 & 9 & -20 \\
\hline 6/13/14 2:00 & 2177 & 1887 & -1.2 & 22 & 6 & 10 \\
\hline 6/13/14 4:00 & 2147 & 1794 & -3.1 & 18 & 3 & 40 \\
\hline $6 / 13 / 146: 00$ & 2044 & 1640 & -5.4 & 32 & 4 & 70 \\
\hline 6/13/14 8:00 & 1953 & 1459 & -7.6 & 47 & 5 & 118 \\
\hline 6/13/14 10:00 & 1876 & 1399 & -7.8 & 39 & 5 & 85 \\
\hline 6/13/14 14:00 & 2148 & 1975 & 8.2 & 10 & 3 & -48 \\
\hline 6/13/14 16:00 & 2185 & 2019 & 10.8 & 9 & 3 & -58 \\
\hline 6/13/14 18:00 & 2209 & 2030 & 9.6 & 6 & 4 & -60 \\
\hline 6/13/14 20:00 & 2214 & 2003 & 6.4 & 7 & 4 & -52 \\
\hline $6 / 13 / 14$ 22:00 & 2219 & 1975 & 3.6 & 7 & 6 & -46 \\
\hline 6/14/14 0:00 & 2210 & 1941 & 3.6 & 13 & 9 & -33 \\
\hline 6/14/14 2:00 & 2202 & 1882 & -1.2 & 16 & 9 & 33 \\
\hline
\end{tabular}


Appendix F

Data for Chapter 6 
Table F.1: Chapter 6 Data

\begin{tabular}{|c|c|c|c|c|}
\hline & E2 & $\mathrm{E} 2.5$ & E3 & E3.5 \\
\hline Latitude & 20.6993 & 20.6992 & 20.6991 & 20.699 \\
\hline Longitude & 116.9186 & 116.9163 & 116.914 & 116.9109 \\
\hline \multirow[t]{2}{*}{ Acropora } & $1 / 0 / 0$ & $85 / 0 / 0$ & $21 / 0 / 0$ & $4 / 0 / 0$ \\
\hline & $2 / 0 / 1$ & $27 / 5 / 16$ & $5 / 1 / 19$ & $0 / 0 / 1$ \\
\hline \multirow[t]{2}{*}{ Caulastrea } & $0 / 0 / 0$ & $0 / 0 / 0$ & $0 / 0 / 0$ & $0 / 0 / 0$ \\
\hline & $0 / 0 / 0$ & $0 / 0 / 0$ & $0 / 0 / 0$ & $0 / 0 / 0$ \\
\hline \multirow[t]{2}{*}{ Cyphastrea } & $0 / 0 / 0$ & $0 / 0 / 0$ & $0 / 0 / 0$ & $0 / 0 / 0$ \\
\hline & $0 / 0 / 0$ & $0 / 0 / 0$ & $0 / 0 / 0$ & $0 / 0 / 0$ \\
\hline \multirow[t]{2}{*}{ Diploastrea } & $0 / 0 / 0$ & $0 / 0 / 0$ & $0 / 0 / 0$ & $4 / 0 / 0$ \\
\hline & $0 / 0 / 0$ & $0 / 0 / 0$ & $0 / 0 / 0$ & $0 / 0 / 0$ \\
\hline \multirow[t]{2}{*}{ Favia } & $0 / 0 / 0$ & $0 / 0 / 0$ & $0 / 0 / 0$ & $0 / 0 / 0$ \\
\hline & $0 / 0 / 0$ & $0 / 0 / 0$ & $1 / 0 / 0$ & $0 / 0 / 0$ \\
\hline \multirow[t]{2}{*}{ Favites } & $1 / 0 / 0$ & $0 / 0 / 0$ & $0 / 0 / 0$ & $2 / 0 / 0$ \\
\hline & $2 / 0 / 0$ & $0 / 1 / 0$ & $0 / 0 / 0$ & $0 / 1 / 0$ \\
\hline \multirow[t]{2}{*}{ Fungia } & $0 / 0 / 0$ & $0 / 0 / 0$ & $0 / 0 / 0$ & $0 / 0 / 0$ \\
\hline & $0 / 0 / 0$ & $0 / 0 / 0$ & $0 / 0 / 0$ & $0 / 0 / 0$ \\
\hline \multirow[t]{2}{*}{ Galaxea } & $0 / 0 / 0$ & $0 / 0 / 0$ & $0 / 0 / 0$ & $0 / 0 / 0$ \\
\hline & $0 / 0 / 0$ & $0 / 0 / 0$ & $0 / 0 / 0$ & $0 / 0 / 0$ \\
\hline \multirow[t]{2}{*}{ Goniastrea } & $0 / 0 / 0$ & $0 / 0 / 0$ & $0 / 0 / 0$ & $1 / 0 / 0$ \\
\hline & $1 / 0 / 1$ & $0 / 0 / 0$ & $0 / 0 / 0$ & $1 / 0 / 0$ \\
\hline \multirow[t]{2}{*}{ Leptoseris } & $0 / 0 / 0$ & $0 / 0 / 0$ & $0 / 0 / 0$ & $0 / 0 / 0$ \\
\hline & $0 / 0 / 0$ & $0 / 0 / 0$ & $0 / 0 / 0$ & $0 / 0 / 0$ \\
\hline \multirow[t]{2}{*}{ Montipora } & $1 / 0 / 0$ & $2 / 0 / 0$ & $0 / 0 / 0$ & $8 / 0 / 0$ \\
\hline & $0 / 0 / 0$ & $0 / 0 / 1$ & $0 / 0 / 0$ & $0 / 0 / 0$ \\
\hline \multirow[t]{2}{*}{ Oulastrea } & $0 / 0 / 0$ & $0 / 0 / 0$ & $0 / 0 / 0$ & $0 / 0 / 0$ \\
\hline & $0 / 0 / 0$ & $0 / 0 / 0$ & $0 / 0 / 0$ & $0 / 0 / 0$ \\
\hline \multirow[t]{2}{*}{ Pavona } & $0 / 0 / 0$ & $0 / 0 / 0$ & $0 / 0 / 0$ & $1 / 0 / 0$ \\
\hline & $0 / 0 / 0$ & $0 / 0 / 0$ & $0 / 0 / 0$ & $0 / 1 / 1$ \\
\hline \multirow[t]{2}{*}{ Platygyra } & $0 / 0 / 0$ & $1 / 0 / 0$ & $0 / 0 / 0$ & $0 / 0 / 0$ \\
\hline & $0 / 0 / 0$ & $0 / 0 / 0$ & $0 / 0 / 0$ & $0 / 0 / 0$ \\
\hline \multirow[t]{2}{*}{ Pocillopora } & $4 / 0 / 0$ & $4 / 0 / 0$ & $2 / 0 / 0$ & $1 / 0 / 0$ \\
\hline & $13 / 0 / 0$ & $4 / 0 / 4$ & $0 / 0 / 2$ & $1 / 0 / 1$ \\
\hline \multirow[t]{2}{*}{ Porites } & $10 / 0 / 0$ & $68 / 0 / 0$ & $114 / 0 / 0$ & $108 / 0 / 0$ \\
\hline & $11 / 0 / 5$ & $10 / 1 / 00$ & $112 / 3 / 20$ & $68 / 2 / 13$ \\
\hline \multirow[t]{2}{*}{ Psammocora } & $0 / 0 / 0$ & $0 / 0 / 0$ & $0 / 0 / 0$ & $0 / 0 / 0$ \\
\hline & $0 / 0 / 0$ & $0 / 0 / 0$ & $0 / 0 / 0$ & $0 / 0 / 0$ \\
\hline \multirow[t]{2}{*}{ Stylophora } & $55 / 0 / 0$ & $136 / 0 / 0$ & $195 / 0 / 0$ & $160 / 0 / 0$ \\
\hline & $70 / 0 / 5$ & $50 / 2 / 8$ & $110 / 14 / 43$ & $28 / 22 / 91$ \\
\hline \multirow[t]{2}{*}{ Millepora } & $0 / 0 / 0$ & $0 / 0 / 0$ & $0 / 0 / 0$ & $0 / 0 / 0$ \\
\hline & $0 / 0 / 0$ & $0 / 0 / 0$ & $0 / 0 / 0$ & $0 / 0 / 0$ \\
\hline
\end{tabular}


Table F.2: Chapter 6 Data

\begin{tabular}{|c|c|c|c|c|}
\hline & E4 & $\mathrm{E} 4.5$ & E5 & E6 \\
\hline Latitude & 20.699 & 20.6991 & 20.6993 & 20.6993 \\
\hline Longitude & 116.9077 & 116.9051 & 116.9024 & 116.8945 \\
\hline \multirow[t]{2}{*}{ Acropora } & $0 / 0 / 0$ & $27 / 0 / 0$ & $117 / 0 / 0$ & $0 / 0 / 0$ \\
\hline & $1 / 0 / 1$ & $68 / 5 / 2$ & $15 / 3 / 127$ & $0 / 0 / 0$ \\
\hline \multirow[t]{2}{*}{ Caulastrea } & $0 / 0 / 0$ & $0 / 0 / 0$ & $0 / 0 / 0$ & $0 / 0 / 0$ \\
\hline & $0 / 0 / 0$ & $0 / 0 / 0$ & $0 / 0 / 0$ & $0 / 0 / 0$ \\
\hline \multirow[t]{2}{*}{ Cyphastrea } & $0 / 0 / 0$ & $0 / 0 / 0$ & $0 / 0 / 0$ & $0 / 0 / 0$ \\
\hline & $0 / 0 / 0$ & $0 / 0 / 0$ & $0 / 0 / 0$ & $0 / 0 / 0$ \\
\hline \multirow[t]{2}{*}{ Diploastrea } & $1 / 0 / 0$ & $0 / 0 / 0$ & $0 / 0 / 0$ & $0 / 0 / 0$ \\
\hline & $0 / 0 / 0$ & $0 / 0 / 0$ & $0 / 0 / 0$ & $0 / 0 / 0$ \\
\hline \multirow[t]{2}{*}{ Favia } & $0 / 0 / 0$ & $6 / 0 / 0$ & $3 / 0 / 0$ & $0 / 0 / 0$ \\
\hline & $0 / 0 / 0$ & $0 / 0 / 0$ & $1 / 1 / 02$ & $0 / 0 / 0$ \\
\hline \multirow[t]{2}{*}{ Favites } & $3 / 0 / 0$ & $6 / 0 / 0$ & $3 / 0 / 0$ & $0 / 0 / 0$ \\
\hline & $0 / 0 / 0$ & $8 / 0 / 3$ & $2 / 1 / 07$ & $0 / 0 / 0$ \\
\hline \multirow[t]{2}{*}{ Fungia } & $0 / 0 / 0$ & $0 / 0 / 0$ & $0 / 0 / 0$ & $0 / 0 / 0$ \\
\hline & $0 / 0 / 0$ & $0 / 0 / 0$ & $1 / 0 / 0$ & $0 / 0 / 0$ \\
\hline \multirow[t]{2}{*}{ Galaxea } & $0 / 0 / 0$ & $0 / 0 / 0$ & $1 / 0 / 0$ & $0 / 0 / 0$ \\
\hline & $0 / 0 / 0$ & $0 / 0 / 0$ & $0 / 0 / 0$ & $0 / 0 / 0$ \\
\hline \multirow[t]{2}{*}{ Goniastrea } & $3 / 0 / 0$ & $18 / 0 / 0$ & $1 / 0 / 0$ & $0 / 0 / 0$ \\
\hline & $5 / 1 / 00$ & $12 / 1 / 02$ & $6 / 4 / 03$ & $0 / 0 / 0$ \\
\hline \multirow[t]{2}{*}{ Leptoseris } & $0 / 0 / 0$ & $0 / 0 / 0$ & $0 / 0 / 0$ & $0 / 0 / 0$ \\
\hline & $0 / 0 / 0$ & $0 / 0 / 0$ & $0 / 0 / 0$ & $0 / 0 / 0$ \\
\hline \multirow[t]{2}{*}{ Montipora } & $5 / 0 / 0$ & $3 / 0 / 0$ & $0 / 0 / 0$ & $0 / 0 / 0$ \\
\hline & $0 / 0 / 3$ & $0 / 0 / 1$ & $0 / 0 / 0$ & $0 / 0 / 0$ \\
\hline \multirow[t]{2}{*}{ Oulastrea } & $0 / 0 / 0$ & $0 / 0 / 0$ & $0 / 0 / 0$ & $0 / 0 / 0$ \\
\hline & $0 / 0 / 0$ & $0 / 0 / 0$ & $0 / 0 / 1$ & $0 / 0 / 0$ \\
\hline \multirow[t]{2}{*}{ Pavona } & $25 / 0 / 0$ & $15 / 0 / 0$ & $20 / 0 / 0$ & $0 / 0 / 0$ \\
\hline & $0 / 26 / 4$ & $1 / 6 / 10$ & $3 / 27 / 09$ & $0 / 0 / 0$ \\
\hline \multirow[t]{2}{*}{ Platygyra } & $0 / 0 / 0$ & $0 / 0 / 0$ & $0 / 0 / 0$ & $0 / 0 / 0$ \\
\hline & $0 / 0 / 0$ & $0 / 0 / 0$ & $0 / 0 / 0$ & $0 / 0 / 0$ \\
\hline \multirow[t]{2}{*}{ Pocillopora } & $1 / 0 / 0$ & $0 / 0 / 0$ & $9 / 0 / 0$ & $0 / 0 / 0$ \\
\hline & $0 / 0 / 0$ & $0 / 0 / 3$ & $0 / 0 / 9$ & $0 / 0 / 1$ \\
\hline \multirow[t]{2}{*}{ Porites } & $20 / 0 / 0$ & $66 / 0 / 0$ & $147 / 0 / 0$ & $0 / 0 / 0$ \\
\hline & $24 / 2 / 6$ & $24 / 0 / 6$ & $74 / 6 / 20$ & $0 / 0 / 0$ \\
\hline \multirow[t]{2}{*}{ Psammocora } & $1 / 0 / 0$ & $0 / 0 / 0$ & $0 / 0 / 0$ & $0 / 0 / 0$ \\
\hline & $0 / 0 / 0$ & $0 / 0 / 0$ & $0 / 0 / 0$ & $0 / 0 / 0$ \\
\hline \multirow[t]{2}{*}{ Stylophora } & $352 / 0 / 0$ & $53 / 0 / 0$ & $25 / 0 / 0$ & $0 / 0 / 0$ \\
\hline & $148 / 21 / 79$ & $46 / 3 / 1$ & $24 / 1 / 19$ & $0 / 0 / 0$ \\
\hline \multirow[t]{2}{*}{ Millepora } & $0 / 0 / 0$ & $0 / 0 / 0$ & $0 / 0 / 0$ & $0 / 0 / 0$ \\
\hline & $0 / 0 / 0$ & $0 / 0 / 0$ & $0 / 0 / 0$ & $0 / 0 / 0$ \\
\hline
\end{tabular}


Table F.3: Chapter 6 Data

$\begin{array}{lllllllll} & \text { E2 } & \text { E2.5 } & \text { E3 } & \text { E3.5 } & \text { E4 } & \text { E4.5 } & \text { E5 } & \text { E6 } \\ \text { Anemone } & 0 & 3 & 8 & 4 & 0 & 0 & 0 & 0 \\ \text { CCA } & 0 & 3 & 12 & 0 & 1 & 0 & 0 & 0 \\ & 193 & 55 & 18 & 7 & 2 & 0 & 0 & 0 \\ \text { Halimeda } & 131 & 20 & 1 & 2 & 0 & 1 & 2 & 0 \\ & 12 & 21 & 6 & 6 & 14 & 0 & 0 & 0 \\ \text { Turf-algae } & 285 & 27 & 4 & 11 & 14 & 16 & 13 & 1 \\ \text { Macro-algae } & 42 & 46 & 47 & 90 & 31 & 189 & 138 & 0 \\ & 39 & 51 & 153 & 148 & 242 & 377 & 222 & 102 \\ \text { Seagrass } & 23 & 125 & 475 & 460 & 22 & 159 & 157 & 976 \\ & 5 & 134 & 407 & 445 & 11 & 48 & 127 & 979 \\ \text { Sponge } & 0 & 0 & 0 & 0 & 0 & 0 & 0 & 0 \\ & 27 & 3 & 0 & 2 & 0 & 0 & 0 & 0 \\ \text { Coral rubble } & 182 & 106 & 37 & 27 & 345 & 257 & 251 & 0 \\ & 195 & 141 & 36 & 75 & 452 & 280 & 166 & 0 \\ \text { Pavement } & 282 & 2 & 0 & 6 & 4 & 7 & 27 & 0 \\ & 273 & 55 & 8 & 10 & 5 & 3 & 0 & 0 \\ \text { Sand } & 159 & 432 & 272 & 321 & 184 & 204 & 252 & 237 \\ & 221 & 352 & 239 & 215 & 173 & 200 & 172 & 167\end{array}$

